\title{
Endocrine differentiation in colorectal cancer
}

Citation for published version (APA):

de Bruine, A. P. (1993). Endocrine differentiation in colorectal cancer. [Doctoral Thesis, Maastricht University]. Datawyse / Universitaire Pers Maastricht. https://doi.org/10.26481/dis.19930625ab

Document status and date:

Published: 01/01/1993

DOI:

10.26481/dis.19930625ab

Document Version:

Publisher's PDF, also known as Version of record

\section{Please check the document version of this publication:}

- A submitted manuscript is the version of the article upon submission and before peer-review. There can be important differences between the submitted version and the official published version of record.

People interested in the research are advised to contact the author for the final version of the publication, or visit the DOI to the publisher's website.

- The final author version and the galley proof are versions of the publication after peer review.

- The final published version features the final layout of the paper including the volume, issue and page numbers.

Link to publication

\footnotetext{
General rights rights.

- You may freely distribute the URL identifying the publication in the public portal. please follow below link for the End User Agreement:

www.umlib.nl/taverne-license

Take down policy

If you believe that this document breaches copyright please contact us at:

repository@maastrichtuniversity.nl

providing details and we will investigate your claim.
}

Copyright and moral rights for the publications made accessible in the public portal are retained by the authors and/or other copyright owners and it is a condition of accessing publications that users recognise and abide by the legal requirements associated with these

- Users may download and print one copy of any publication from the public portal for the purpose of private study or research.

- You may not further distribute the material or use it for any profit-making activity or commercial gain

If the publication is distributed under the terms of Article $25 \mathrm{fa}$ of the Dutch Copyright Act, indicated by the "Taverne" license above, 


\section{ENDOCRINE DIFFERENTIATION IN COLORECTAL CANCER}


Boekverzorging: Datawyse I Universitaire Pers Maastricht

\title{
CIP DATA KONLNKLIJKE BIBLIOTHEEK, DEN HAAG
}

\author{
Bruïne, Adriaan Pieter de
}

Endocrine differentiation in colorectal cancer /

Adriaan Pieter de Bruine.

Maastricht Universitaire Pers Maastricht. - Ill.

Thesis Maastricht. - With ref. - With summary in Dutch.

ISBN 90-5278-080-3

NUGI 742

Subject headings: endocrine differentiation / colorectal cancer

De druk van dit proefschrift werd financieel gesteund door Sandoz b.v. 


\section{ENDOCRINE DIFFERENTIATION IN COLORECTAL CANCER}

\section{PROEFSCHRIFT}

ter verkrijging van de graad van doctor

aan de Rijksuniversiteit Limburg te Maastricht, op gezag van de Rector Magnificus, Prof.mr M.J. Cohen, volgens het besluit van het College van Dekanen, in het openbaar te verdedigen op vrijdag, 25 juni 1993 om 14.00 uur

door

Adriaan Pieter de Bruïne

geboren te Comodoro Rivadavia (Argentinië) in 1957

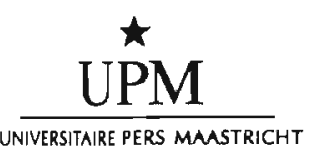




\section{Promotor:}

Prof.dr. F.T. Bosman

\section{Co-promotor:}

Dr. W.N.M. Dinjens

Beoordelingscommissie:

Prof.dr. G. Kootstra (voorzitter)

Prof.dr. Ph.U. Heitz (Universität von Zürich)

Prof.dr. A.C. Nieuwenhuijzen Kruseman

Prof.dr. F.C.S. Ramaekers

Prof.dr. R.W. Stockbrügger 
"Die Natur läßt die Erscheinungen fließen. Wir sind es, die scharfe Grenzen suchen, aus menschlich berechtigten Gründen, jedoch mit einiger Gewalt."

F. Feyrter, 1938.

Aan mijn ouders

\author{
Aan Sophie \\ Just \\ Eline \\ Isabelle
}




\section{Promangitura}

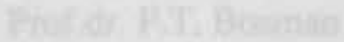

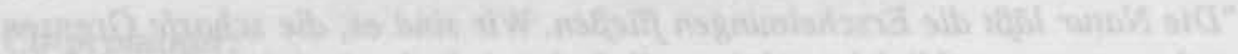

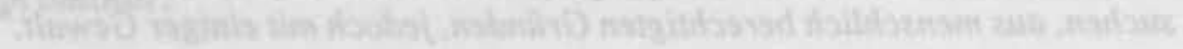

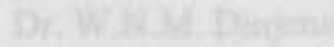

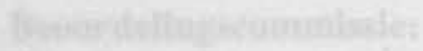

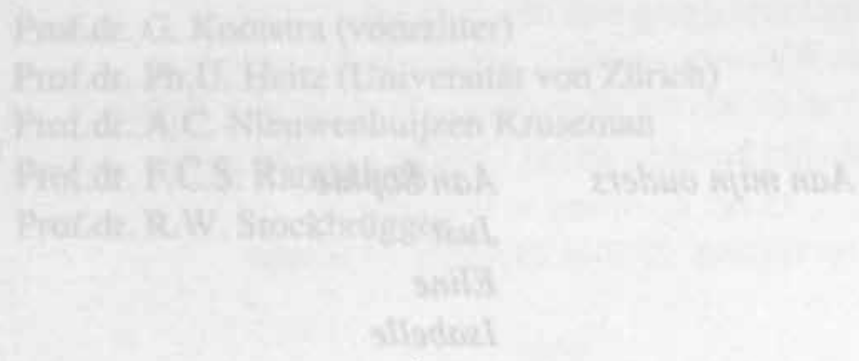




\section{CONTENTS}

\section{LIST OF ABBREVIATIONS}

\section{Chapter 1}

\section{GENERAL INTRODUCTION}

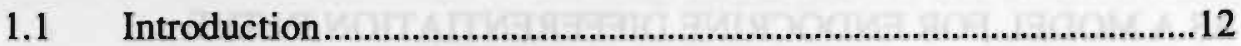

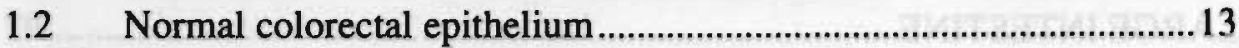

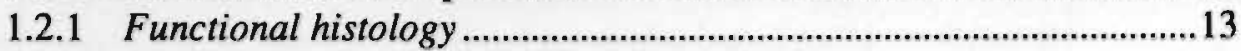

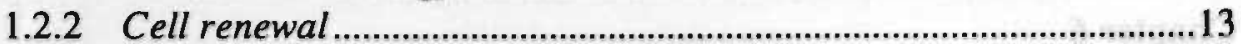

1.2.3 Regulation of epithelial cell differentiation ....................................... 14

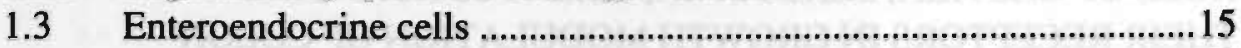

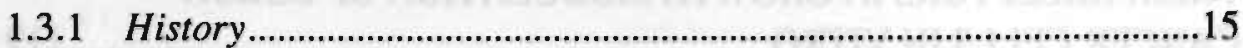

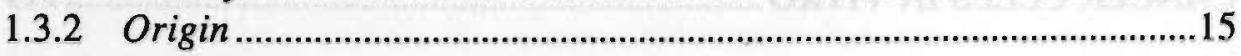

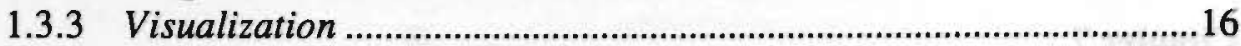

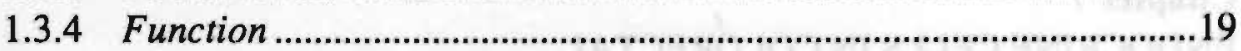

1.4 Growth regulation by gastrointestinal neurohormones ...................20

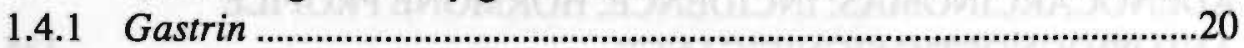

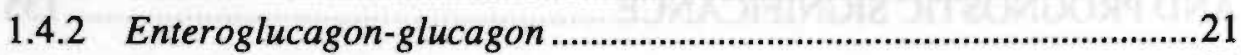

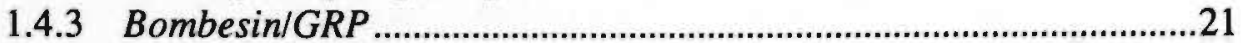

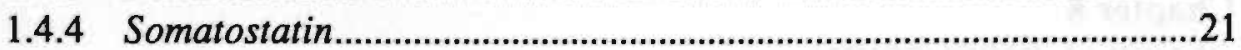

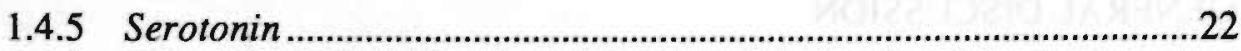

1.5 Pathology of enteroendocrine cells ..............................................22

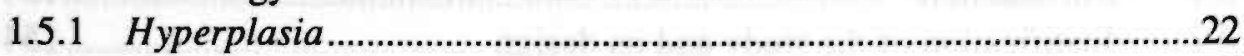

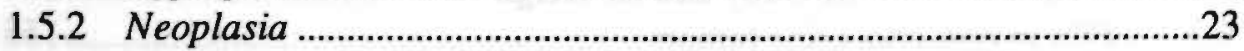

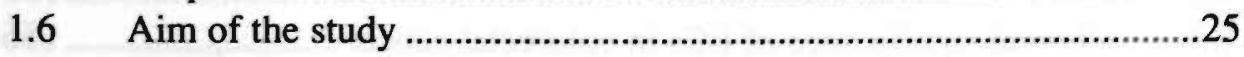

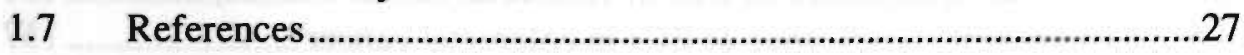




\section{Chapter 2}

RENEWAL OF ENTEROCHROMAFFIN CELLS IN THE RAT

CAECUM

\section{Chapter 3}

NCI-H716 CELLS AS A MODEL FOR ENDOCRINE

DIFFERENTIATION IN COLORECTAL CANCER.

\section{Chapter 4}

EXTRACELLULAR MATRIX COMPONENTS INDUCE

ENDOCRINE DIFFERENTIATION IN VITRO IN NCI-H716

CELLS

\section{Chapter 5}

HUMAN CACO-2 CELLS TRANSFECTED WITH C-HA-RAS

AS A MODEL FOR ENDOCRINE DIFFERENTIATION IN THE

LARGE INTESTINE

\section{Chapter 6}

ROLE OF GASTRIN, SEROTONIN, SOMATOSTATIN AND

THEIR RECEPTORS IN GROWTH MODULATION OF COLON

CANCER CELLS IN VITRO

\section{Chapter 7}

ENDOCRINE CELLS IN COLORECTAL

ADENOCARCINOMAS: INCIDENCE, HORMONE PROFILE AND PROGNOSTIC SIGNIFICANCE

\section{Chapter 8}

\section{GENERAL DISCUSSION}

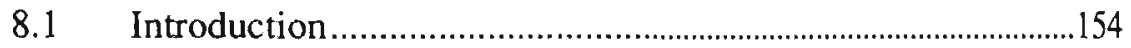

8.2 Justification of the study and its design ....................................... 154

8.3 ECs in non-endocrine tumors .....................................................

8.4 Clinical significance of ECs in colorectal cancer ........................... 156

8.5 Biological significance of ECs in colorectal cancer .........................157

8.5.1 Regulation of endocrine differentiation ...........................................157

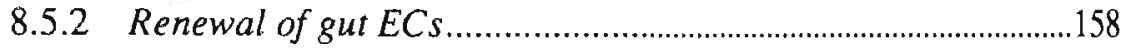

8.5.3 Neurohormonal regulation of cancer cell growth ........................... 159 


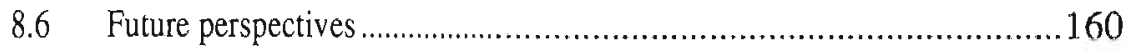

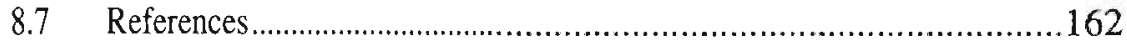

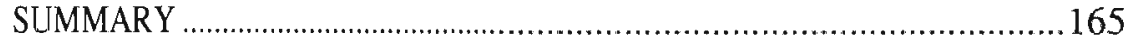

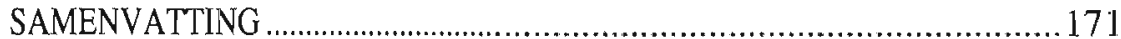

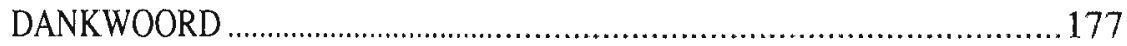

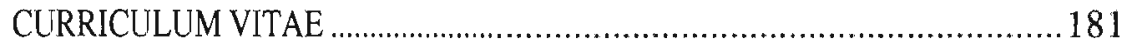




\section{List of abbreviations}

\begin{tabular}{ll} 
APUD & Amine Precursor Uptake and Decarboxylation \\
BrdU & 5-bromo-2'-deoxyuridine \\
BSA & Bovine serum albumin \\
CEA & Carcinoembryonic antigen \\
CGA & Chromogranin A \\
DMEM & Dulbecco's modified Eagles' minimal essential medium \\
DMF & Dimethylformamide \\
DMSO & Dimethylsulfoxide \\
DOPA & Dihydroxyphenylalanine \\
DTT & Dithiotreitol \\
EC & Endocrine cell \\
EC & Enterochromaffin (Chapter 2) \\
ECM & Extracellular matrix \\
EDTA & Ethylenediaminetetracetic acid \\
FBS & Fetal bovine serum \\
bFGF & Basic fibroblast growth factor \\
FTTC & Fluorescein isothiocyanate \\
HID-AB & High iron diamine-alcian blue \\
HSPG & Heparan sulphate proteoglycan \\
5-HT & 5-Hydroxytryptamine/serotonin \\
K & Dissociation constant \\
LC & Lower crypt half \\
LI & Labeling index \\
NaBT & Sodium butyrate \\
NE & Neuroendocrine \\
NEM & N-Ethylmaleimide \\
NSE & Neuron specific enolase \\
PBS & Phosphate buffered saline \\
PMA & Phorbol myristate acetate \\
RA & Retinoic acid \\
SC & Secretory component \\
SDS & Sodium dodecylsulphate \\
SRIF & Somatotropin release inhibiting factor/somatostatin \\
SSC & Standard saline citrate \\
SSTR & Somatostatin receptor \\
TGF & Transforming growth factor $\beta$ \\
TRITC & Tetramethyl rhodamine isothiocyanate \\
UC & Upper crypt half \\
& \\
\hline
\end{tabular}




\section{CHAPTER 1}

\section{GENERAL INTRODUCTION}

"Wenn man sich mit der Histologie pathologischer Prozesse am menschlichen Darme zu beschäftigen beginnt, so bemerkt man bald, dass, trotz der sehr zahlreichen Arbeiten, manche Frage der normalen Histologie dieses Gebietes noch nicht gelöst ist, die Grenzen des normalen Vorkommens manchen Zellarten noch nicht abgesteckt sind und dass die Herkunft gewisser Gebilde unaufgeklärt ist."

J.E. Schmidt, 1905 . 


\subsection{Introduction}

Colorectal cancer is a common form of cancer in Western Europe and the United States, second only to lung cancer and prostate cancer in males and breast cancer in females $(1,2)$. In the U.S., 140.000 new cases are diagnosed and 60.000 deaths are caused by this disease every year (3). In The Netherlands, over 7000 new cases are diagnosed every year, representing $12 \%$ of invasive cancers and $10 \%$ of cancer deaths in men and 14\% of both invasive cancers and cancer deaths in women (2). Colorectal carcinoma death rates in The Netherlands have not decreased during the past decades (4).

Surgery so far is the only effective treatment for colorectal carcinoma, with about $80 \%$ of patients considered operable at the time of diagnosis (5). However, even after "curative" resection, 5-year survival is only in the order of $50 \%$ (6). Death is related to recurrent disease, probably due to occult residual tumor foci outside the area of the primary tumor. Local radiotherapy effectively reduces local recurrence in rectal cancer, but has no impact on survival (7). Systemic "adjuvant" chemo- and immunotherapy have not shown convincing and reproducible evidence of significant benefit (8), although recently some success has been reported for fluorouracil combined with levamisole in Dukes $C$ colon cancer and with leucovorin in Dukes B and C rectal cancer (9). To reduce morbidity and mortality from minimal residual disease, development of alternative modes of systemic (adjuvant) therapy is necessary. Manipulation of colorectal tumorgrowth by peptide hormones or biogenic amines, produced by gastrointestinal endocrine cells (ECs), has barely been explored (10,11).

Accurate pathologic investigation and reporting of colorectal cancer specimens is essential not only for diagnosing the disease, but especially for assessing prognosis and planning treatment (12). For colorectal carcinoma, the best available prognostic indicator still is tumor stage, based on the Dukes' classification (13). However, within a certain stage, tumor behavior is not uniform. Histologic grading (14) does not solve this problem. Though it does correlate with prognosis, it can not predict behavior of individual tumors, is subjective and therefore may fall short of reproducibility. Moreover, it correlates with Dukes' staging and therefore does not contribute as an independent prognostic factor. For this reason, additional tumor markers accurately predicting tumor behavior have been sought (15). Ideally, such markers should not only be prognostically relevant, but also portend response to specific forms of therapy. One of the markers that has received relatively little attention, is the presence of endocrine cells. The present study was performed to elucidate the biological and clinical relevance of endocrine differentiation in colorectal cancer. 


\subsection{Normal colorectal epithelium}

\subsubsection{Functional histology}

The main functions of the human large intestine are absorption of salt, water and proteins from the bowel lumen $(16,17)$, secretion of potassium and bicarbonate into the bowel lumen (18), and propulsion and elimination of undigested faecal material, which is facilitated by secretion of mucus. The most important anatomical and functional units in colorectal mucosa are the crypts of Lieberkiihn, which are regularly spaced tube-shaped invaginations lined by epithelium, with an apical opening in contact with the bowel lumen. The crypts reach from the more or less flat luminal surface to the muscularis mucosae, which separates the mucosa from the underlying submucosa. The crypt- and surface epithelium is one cell layer thick, and consists of three different cell types: columnar cells capable of absorption and secretion, goblet cells producing mucin, and ECs producing biogenic amines and peptide hormones. A fourth intestinal cell type, the Paneth cell, normally found in the small intestine, is only occasionally found in normal caecum or proximal ascending colon $(16,17)$. Gradual differences in distribution of the three cell lineages along the crypt length can be noted. ECs are most prominent in the deep parts of the crypts (16). Goblet cells predominate in the crypt epithelium and columnar cells in the surface epithelium (17).

\subsubsection{Cell renewal}

The study of cell renewal in the digestive tract has been greatly facilitated by the introduction of radioactive DNA precursors such as ${ }^{3} \mathrm{H}$-thymidine, which can be visualized by autoradiography, for labeling of cells in the DNA-synthesis phase of the cell cycle (19). By administering this compound as a pulse-dose, labeled gut mucosal cells in S-phase can be visualized, and by establishing the fraction of labeled mitoses at different time intervals, the duration of the phases in the cell-cycle can be determined (20). In recent years, also non-radioactive methods for identification of S-phase cells have been developed, including the thymidine analogue 5-bromo-2'-deoxyuridine (BrdU), which can be visualized by immunocytochemistry $(21,22)$.

Cell kinetic studies indicate that colorectal epithelium is continuously renewed from the crypt base, where a stem-cell common for all cell lineages is presumed to reside $(23,24)$. Proliferation is restricted to the lower half or two-thirds of the crypt, where mitotic figures occur $(25,26)$. The cells differentiate and maturate as they migrate up the crypt into the surface epithelium, where they desquamate into the bowel lumen from the mid-zone between adjacent crypt orifices (27). Turnover time of colorectal epithelium is about 3 to 8 days in humans (28-30) and 2 to 5 days in rodents $(26,31)$. ECs in gastrointestinal epithelium traditionally have been considered to be a static non-dividing subpopulation (32). Recently, evidence has accumulated showing that ECs are also subject to 
continuous renewal. Discussion remained whether these cells themselves are capable of proliferation (33-35), or lack proliferative activity and are derived from immature precursor cells $(36,37)$. Most authors agree that ECs have a slower rate of migration and replacement than other cell types, with an estimated turnover time for large intestinal enterochromaffin (serotonin containing) cells ranging from 23 to 100 days $(33,36,37)$.

\subsubsection{Regulation of epithelial cell differentiation}

The functional integrity of intestinal epithelium does not only depend on continuous cell-renewal, but also on appropriate and balanced differentiation of epithelial cells. Intestinal epithelial differentiation is a complex process, influenced by steroid- and peptide hormones (38,39), growth factors (40-42), and vitamins (43). These substances can exert their action via endocrine, paracrine and luminal routes. An important role in differentiation induction is played by the extracellular matrix (ECM), which appears to mitigate the effects of locally or systemically acting differentiation inducers (44). Numerous studies involving in vitro recombination of endo- and mesoderm or co-culturing of epithelial cells and ECM components indicate that direct contacts between epithelial and mesenchymal structures are essential for the fulfillment of this role (45-49). For normal colorecta] epithelium, the support of an intact basement membrane and a pericryptal (myo)fibroblast-sheath are essential elements for control of migration and differentiation $(50,51)$. The basement membrane is the product of the concerted interaction of epithelial and mesenchymal cells. Epithelial-stromal interactions are established by integrins, heterodimeric transmembrane molecules consisting of different combinations of $\alpha$ and $\beta$ chains, which can bind to one or more ECM molecules. Via intracellular filaments such as talin and actinin, the cytoskeleton is connected with the ECM. Thus, integrins function by integrating stroma and epithelium. Integrins also elicit diverse intracellular responses (52). In normal epithelium of the large intestine, the $\beta_{1}$-family is expressed (53).

Epithelial-stromal contacts have also been proven pivotal for induction of the endocrine phenotype in the intestines. This has been demonstrated in embryonic recombination experiments, where direct contact of endoderm with the appropriate type of mesenchyme determines the extent and pattern of endocrine differentiation (54). In neoplasia, ECs are mainly encountered in nude mice xenografts, suggesting a role for ECM in inducing endocrine features (55). In vitro, growth factors appear to be necessary to maintain the endocrine character of neoplastic cells in primary tumor cultures (56). These observations could indicate that the induction of endocrine differentiation, resulting from the direct contact between epithelium and ECM, is mediated by stromal modification of the epithelial response to growth factors. 


\subsection{Enteroendocrine cells}

\subsubsection{History}

The diffuse neuroendocrine (NE) system is a complex of ECs, widely distributed in numerous organs and tissues, including the gastrointestinal tract, where the cells are collectively named enteroendocrine cells $(57,58)$. Solitary cells or more or less clearly defined clusters of these cells are localized intraepithelial (59), aithough the mucosal lamina propria is also known to contain ECs (60-62). Enteroendocrine cells are preferentially situated in the basal crypt-regions, and to a lesser extent also occur in a more superficial position $(59,63)$. Ever since their first discovery, cells of this system have been an intriguing subject for many researchers. Already in the late 19th and early 20 th century, the existence of these cells in humans was demonstrated by investigators as Schmidt (64), Masson (65) and Oberndorfer (66). The discovery of ECs was based on their capacity of binding metal from solutions of chromium or silver salts, which led to names as chromaffin (67), enterochromaffin (68) and argentaffin (65) cells. Their most striking light microscopical trait, a clear cytoplasm and finely dispersed nuclear chromatin, resulted in terms as "Gelbe Zellen", "Helle Zellen" (69), or "Cellules Claires". Alternatively, they were named after the investigators themselves (e.g. Feyrter cells (69), Kultschitzky cells (70)). Gradually, with the aid of sophisticated microscopical, histochemical and immunological techniques, more and more became known of their subcellular morphology and, by disclosure of their specific secretory products, a substantial amount of knowledge developed on their function as a regulatory system forming a part of, or co-operating with nervous and endocrine systems in various parts of the body.

\subsubsection{Origin}

One of the investigators who has been of major importance in constructing the concept of a diffuse or dispersed NE system is Pearse (71), who was the first to fit together cells from a number of different organs on the basis of their common morphological, cytochemical and embryological characteristics. He called the units of this system "APUD cells", an acronym for Amine Precursor Uptake and Decarboxylation, referring to their capacity of taking up amino acid precursors such as dihydroxyphenylalanine (DOPA) and 5-hydroxytryptophan (5-HTP) from which the biogenic monoamines dopamine and 5-hydroxytryptamine or serotonin (5-HT) can be produced by enzymatic decarboxylation (72). Apart from the production, storage and secretion of polypeptide hormones (73), this is the most typical common cytochemical property of the cells in question. The APUD system as proposed by Pearse over the years has grown to contain cells of a great variety of organs, ranging from endocrine glands as the anterior pituitary (74), thyroid gland (75), parathyroids (76), and adrenal gland (77) via the carotid body and paraganglia (78) to primarily non-endocrine organs such as 
the lungs (79), digestive tract including the pancreas (80), urogenital tract (81) and skin (82). To explain the common characteristics of these widely varying cell types, Pearse proposed that the cells were derived from a common embryonic precursor cell, and originally considered the $\mathrm{NE}$ cell of the neural crest to be the most likely candidate. Later, when such an origin was disputed by other investigators (83-86), he suggested that all peptide-hormone producing cells derived from the "NE programmed epiblast" (87), which is difficult to refute by scientific investigation, because of the very early phase in embryogenesis. Although for some of the cell types mentioned above (e.g. thyroid C-cells, adrenal medullary cells and melanoblasts in the skin) a neuroectodermal derivation is very likely, for the ECs occurring in respiratory and digestive tracts an endodermal stem cell, shared with the other lineages in these tissues, is clearly favored (88-91). Pearse proposed that this "unitarian" origin for all enteric cell lineages should be modified to an "extended unitarian" hypothesis for gut ECs, implying that the progenitor of these cells arises from a primary stem cell ancestor only after an undetermined number of doublings (92). Although a common endodermal stem cell now seems generally accepted, what remains to be established is whether differentiation takes place along strictly separate lines or, alternatively, if transitions between the various phenotypes occur. Furthermore, whether or not each cell type represents an equally mature state of terminal differentiation is still undetermined.

\subsubsection{Visualization}

In routine histochemical staining the only apparent morphological feature of ECs is their relatively clear appearance. To visualize them properly, histochemistry, immunohistochemistry and/or electron microscopy are necessary. A combination of at least two of these techniques is advisable for positive identification of endocrine features (93).

\section{1-Histochemical staining techniques.}

Three methods deserve to be mentioned here:

a) Silver impregnations, either the argentaffin reaction of Masson-Fontana $(65,94)$, reflecting the presence of serotonin $(95)$, and based on reduction of ionic silver by an endogenous reductase, or a variety of argyrophil methods (Grimelius, Churukian-Schenk, Linder etc.)(96-100), which demonstrate dense core granules, and require an exogenous reducing agent.

b) Formalin (vapor) induced fluorescence of biogenic amines $(101,102)$.

c) Aniline dyes (lead-hematoxylin, "masked" metachromasia in toluidine blue after acid hydrolysis), either singly $(103,104)$ or in combination (105).

Especially the silver impregnation techniques are rather useful and remain fairly commonly used histochemical staining procedures. 


\section{2-Immunohistochemistry.}

This technique constitutes the most sensitive and specific way of demonstrating ECs. EC markers can be subdivided in general or "pan"-NE markers (neurosecretory granule related or -independent), which identify ECs as such, and neurohormonal synthesis products, which define subsets of ECs. The polypeptide hormones and biogenic amines of gastrointestinal ECs are listed in Table 1. The following general NE markers are most commonly used.

a) Neuron specific enolase (NSE) was one of the first general NE markers to be described (106). Enolases are soluble cytoplasmic metallo-enzymes which catalyze the interconversion of 1-phospho-D-glycerate and phosphoenolpyruvate in the glycolytic pathway, and are present in every cell. The enolases are dimeric proteins $\left(M_{\mathrm{r}} 87 \mathrm{kD}\right)$, composed of $\alpha, \beta$ and $\gamma$ subunits. The $\gamma-\gamma$ dimer is present in neurons and NE cells. NSE immunoreactivity has been demonstrated in NE tissues (107) and NE tumors (108). Moreover, it has been used as a serum marker for NE tumors (109). However, NSE immunoreactivity is not "specific" for NE cells, because the $\gamma-\gamma$ dimer is not restricted to NE cells, and because cross reactivity of antibodies with the various subunits can occur. The use of NSE in the diagnosis of NE characteristics is attractive when NE cells are only sparsely granulated, because its demonstration is independent of the presence of neurosecretory granules.

b) Protein gene product 9.5 (PGP 9.5), like NSE, is a soluble cytoplasmic protein, originally isolated from the brain (110), widely distributed in nerves (111) and reported to occur in NE tumors (112). Its function is unknown. Its immunoreactivity is also NE granule independent.

c) Chromogranins are a group of acidic monomeric proteins of various sizes, which form a major part of the soluble proteins in the secretory granules of the adrenal medulla (113). Chromogranin A (CGA, $\left.\mathrm{M}_{\mathrm{r}} 68 \mathrm{kD}\right)$, the most applied member of this group, was originally isolated from bovine chromaffin granules (114-116) and later was found to be similar to secretory protein I (117). Human CGA shares homology with bovine CGA in the $\mathrm{N}$-terminal amino acid sequence. The function of CGA is unknown. It might be a precursor for smaller peptides or may play a role in binding intragranular calcium (1.18-120). Also, it may help to stabilize the granule osmotic pressure by interaction with nucleotides and catecholamines (121), or be involved in packaging and/or processing of peptide hormones (122). There seems to be a close relationship between argyrophilia and CGA immunocytochemistry $(123,124)$. Other members of the chromogranin family are chromogranin $B\left(M_{r} 100 \mathrm{kD}\right.$, identical to secretogranin I) and chromogranin $\mathrm{C}\left(\mathrm{M}_{\mathrm{r}} 86 \mathrm{kD}\right.$, identical to pituitary TSP (tyrosine sulfated protein) or secretogranin II) $(117,125)$. Smaller molecular forms have also been identified. The chromogranins are known to be constituents of all types of ECs (126-128), and are produced and secreted by NE tumors (129). As a dense-core granule (>80 nm) related marker, antibodies to chromo- 
TABLE 1. Secretory Products of gastrointestinal ECs ${ }^{1}$

\begin{tabular}{|c|c|c|}
\hline Cell type & Product(s) & Localization \\
\hline $\mathrm{G}$ & $\begin{array}{l}\text { Gastrin, ACTH, Met-enkephalin, } \\
\text { Gawk }\end{array}$ & $\begin{array}{l}\text { Stomach (Antrum) } \\
\text { Duodenum }\end{array}$ \\
\hline IG & Gastrin, Gawk & Small Intestine \\
\hline TG & Tetragastrin & Small lntestine (proximal) \\
\hline $\mathrm{D}$ & Somatostatin & $\begin{array}{l}\text { Stomach } \\
\text { Small Intestine } \\
\text { Large Intestine }\end{array}$ \\
\hline S & Secretin, Gawk & Small Intestine \\
\hline I & Cholecystokinin & Small Intestine \\
\hline $\mathrm{K}$ & GIP & Small Intestine \\
\hline Mo & Motilin & Small Intestine (proximal) \\
\hline N & Neurotensin & Small Intestine (distal) \\
\hline $\mathrm{L}$ & Enteroglucagon, PYY & $\begin{array}{l}\text { Small Intestine } \\
\text { Large Intestine }\end{array}$ \\
\hline $\mathrm{EC}_{\mathbf{l}}$ & 5-HT, Substance P, Leu-enkephalin & $\begin{array}{l}\text { Small Intestine } \\
\text { Large Intestine }\end{array}$ \\
\hline $\mathrm{EC}_{2}$ & 5-HT, Motilin-like, Leu-enkephalin & Small Intestine (proximal) \\
\hline $\mathrm{EC}_{\mathrm{n}}$ & 5-HT, unknown & Stomach \\
\hline $\mathrm{ECL}$ & Histamine & Stomach (Corpus) \\
\hline $\mathrm{D}_{1}$ & unknown & $\begin{array}{l}\text { Stomach } \\
\text { Small Intestine } \\
\text { Large Intestine }\end{array}$ \\
\hline $\mathrm{P}$ & Bombesin/GRP & $\begin{array}{l}\text { Stomach (Antrum) } \\
\text { Duodenum }\end{array}$ \\
\hline PP & Pancreatic Polypeptide & Large lntestine \\
\hline PYY & PYY & Large Intestine \\
\hline $\mathrm{X}$ & unknown & Stomach (Corpus) \\
\hline
\end{tabular}

I The table shows the secretory products and anatomic distribution of endocrine cell types in the gastrointestinal mucosa (239). Nomenclature is based on the Lausanne classification (141). ACTH=adrenocorticotropic hormone; Gawk=chromogranin B 420-493; GIP=gastric inhibitory peptide; $G R P=$ gastrin-releasing peptide; 5 -HT=serotonin; $P Y Y=$ polypeptide $Y Y$.

granins are excellent markers for NE differentiation when the (tumor) cells are sufficiently granulated.

d) Synaptophysin is a glycosylated polypeptide $\left(\mathrm{M}_{\mathrm{r}} 38 \mathrm{kD}\right)$, isolated from bovine neurons (130). It is an integral membrane protein, localized in the membrane of 
small $(40-80 \mathrm{~nm})$ presynaptic secretory vesicles (131). In neurotransmitter vesicles of nervous tissue, synaptophysin occurs as a homo-oligomeric protein, spanning the membrane of these vesicles and binding calcium (132). It has also been proposed that synaptophysin is capable of forming transmembrane channels similar to gap junctions, which may be involved in the accumulation and/or release of vesicular contents (133). Synaptophysin can be found in almost all neurons, in NE cells and NE neoplasms of neural and epithelial origin (134-136). e) Leu-7 originally was identified as an epitope present on the cell surface of natural killer (NK) cells. Antibodies also react with myelin associated glycoprotein in peripheral nerve fibres and normal and neoplastic NE cells (137). Immunoblotting showed that the involved epitope is a carbohydrate moiety of a protein $\left(\mathrm{M}_{\mathrm{r}} 75 \mathrm{kD}\right)$, localized in the matrix of chromaffin granules. It has been suggested that Leu-7 immunoreactivity might be a marker for certain subsets of secretory granules (138).

\section{3-Electron microscopy.}

The ultrastructural hallmark of NE differentiation is the presence of membranebound secretory granules, which can be visualized by electron microscopy as vesicles with a size of $100-400 \mathrm{~nm}$, with osmiophilic contents of variable electron density (139). ECs have been classified according to their variation in granule morphology, which has led to disclosure of many different cell types, and to formulation of the first universally accepted classifications of gut ECs $(140-142)$. Combination of electron microscopy and immunocytochemistry has been developed and forms a powerful technique to combine morphology and function (143).

\subsubsection{Function}

Ultrastructural studies have generated important information on the function of gastrointestinal ECs. These cells are often of so-called "open type", implying that they are interspersed between adjacent epithelial cells, to which they are connected by specialized cell connections (tight- and gap junctions). They furthermore possess apical cytoplasmic extensions, which are in contact with the bowel lumen through a distinct border of microvilli at the cell surface (144). These cells are polarized, with the majority of hormone storing granules located subnuclear in the basal cytoplasm (145). Furthermore, ECs have been shown to be located close to capillaries and nerve endings of the lamina propria (146). These observations have led to the proposition that enteroendocrine cells perform as chemoreceptors, capable of noticing and reacting to changes in the extracellular environment. After adequate stimuli they release their transmitter substances by basolateral exocytosis in the direction of vicinal neurons or vessels, thus acting in a "neuroendocrine" or "endocrine" fashion $(147,148)$. Another option is that ECs serve as "paracrine" regulators, which implies that 
they can influence cells in their direct surroundings by local release of their regulatory substances. Cells for which this has been postulated are for example the somatostatin containing D-cells of the oxyntic and antral mucosa of the stomach (149). These have long lateral cytoplasmic extensions, reaching towards neighboring cells. These cells do not make contact with the lumen and therefore are of "closed type". They also occur elsewhere in the intestines, but do not exclusively produce somatostatin. Thus, by variable routes of secretion, cells of the diffuse endocrine system are capable of influencing a number of bodily functions. In the gastrointestinal tract these cells are considered to act in close co-operation with a complex intramural network of adrenergic, cholinergic and peptidergic neurons, to regulate the digestive process (150).

\subsection{Growth regulation by gasirointestinal neurohormones}

Through production and secretion of bioactive substances, ECs participate in the regulation of intestinal functions, such as secretion, absorption and motility. ECs also play an important role in controlling the continuous renewal of mucosal epithelium and in maintaining mucosal integrity (151). There are ample indications that gut neurohormonal peptides and biogenic amines can modulate proliferation of normal and neoplastic gastrointestinal epithelium. In the context of this thesis, only the neurohormones that may be relevant to the large intestine are summarized.

\subsubsection{Gastrin}

Gastrin is known for stimulation of gastric acid secretion (152). It also is the best documented hormone known to influence proliferation in the gastrointestinal tract. It stimulates growth of oxyntic, duodenal and colonic mucosa in rats $(153,154)$. Growth of intestinal epithelial cells correlates well with physiologic serum levels of gastrin (155). Trophic effects correlate with the presence of specific high affinity receptors for gastrin in the newbom rat (156). Cholecystokinin. a member of the gastrin family, and proglumide, a gastrin antagonist, competitively bind to the gastrin receptor, and inhibit both acid secretion and growth promotion by gastrin (157.158). Kusyk et al. showed increased DNA and protein content in the human colon cancer cell line LoVo upon stimulation with gastrin (159). Sirinek et al. found a $60 \%$ increase in the number of both normal and malignant human colonic as well as gastric epithelial cells upon stimulation with gastrin $(160,161)$. Singh et al. found stimulation of growth in carcinogen induced MC-26 mouse colon carcinoma cells by gastrin, which was antagonized by proglumide. These effects correlated with the presence of both low and high affinity gastrin receptors $(162,163)$. Other reports from this group mention the occurrence of high affinity gastrin receptors on several cell lines derived from 
gastric and colonic cancer (164). Watson et al. found enhanced growth of the colorectal and gastric cancer cell lines HT 29 and MKN45 in vivo when the cells were xenografted in nude mice. This did not occur in vitro, possibly because the growth promoting effect was lost during cell culturing. They also found a proliferative response to gastrin in $55 \%$ of primary cell cultures from gastric and colorectal carcinomas (165-167). Imdahl et al. reported growth stimulation by pentagastrin, which was antagonized by proglumide, in SW 403 colon cancer cells, but only a minor effect in LoVo and LS $174 \mathrm{~T}$ cells, which might be related to the differentiation level of these cell lines (168).

Simopoulos et al. found growth stimulation of intestinal epithelial-like cells by gastrin, neurotensin, glucagon, VIP, somatostatin and bombesin, whereas secretin and CCK seemed ineffective (169). Hoosein et al. demonstrated autocrine growth stimulation by gastrin in HCT 116 and CBS colon carcinoma cells (170).

\subsubsection{Enteroglucagon-Glucagon}

Glucagon belongs to the VIP-secretin peptide hormone family and is present in two molecular forms in the digestive tract: pancreas glucagon and enteroglucagon (171), derived from the same 180 amino acid preprohormone (172). A positive correlation has been observed between proliferative activity and serum enteroglucagon levels in the small intestine (173-175), but contrasting results have also been presented (176). A proliferative effect of enteroglucagon on colorectal epithelium has not unequivocally been demonstrated (177). The definitive status of enteroglucagon as a potential trophic hormone for the intestine awaits isolation of the peptide. Pancreas glucagon has been shown to increase DNA synthesis and content in oxyntic glands, colonic mucosa and intestinal epithelial-like cells $(153,169)$.

\subsubsection{Bombesin/GRP}

Bombesin (Gastrin Releasing Peptide in mammals) stimulates gastrin release (178), and therefore could be of potential interest as an indirect growth promotor. It has been found to increase gastrin levels through enhanced antral gastrin cell proliferation (179). Bombesin also has a direct effect on proliferation. It is a potent mitogen for $3 \mathrm{~T} 3$ fibroblasts and its role as an (autocrine) growth factor in e.g. small cell lung cancer is well established (180). Specific receptors for bombesin/GRP have been found in colon cancer specimens (181).

\subsubsection{Somatostatin}

Somatostatin was originally described as a hypothalamic hormone inhibiting the release of growth hormone (SRIF, Somatotropin Release Inhibiting Factor) (182). It is located in mucosal endocrine cells throughout the gastrointestinal tract and pancreas, where it is believed to function as a paracrine inhibitor of 
release of several gut peptides $(183,184)$. Growth inhibitory effects have been described in normal and neoplastic gastrointestinal cells (185-189). Tumor growth inhibition by SRIF can be either indirect or direct. Indirect inhibition might take place via inhibition of secretion of other hormones (e.g. growth hormone, insulin, gastrin); via inhibition of growth factors (e.g. EGF, IGF-1); via inhibition of angiogenesis; or by modulation of immunological activity (190). Direct inhibition is possible via somatostatin receptors (SSTRs) on tumor cells. SSTRs are present in numerous normal and neoplastic cells of NE and non-NE origin, including the digestive tract $(181,190-193)$. In colorectal adenocarcinomas SSTRs occur in $10-50 \%$ of cases $(181,190)$.

\subsubsection{Serotonin}

The largest bodily supply of serotonin (5-HT) is present in the digestive tract, in enterochromaffin cells and in intramural neurons (194). In the small intestine, crypt cell proliferation is stimulated by 5-HT, acting on a 5-HT1 receptor, stimulating cAMP synthesis and presumably activating type I cAMP dependent protein kinase (195). No effect is found for colonic crypt cells (196). In celiac disease, crypt cell production is accelerated, corresponding with increased tissue and serum levels of 5-HT (197.198). The same holds true for partial intestinal resection, in which the 5-HT content of the remaining intestinal mucosa is increased (199). Low doses of 5-HT stimulate cell proliferation in carcinogen induced tumors of rat colon. 5-HT antagonists inhibit cell proliferation in both rat colonic tumors and xenografts of human colonic tumors, an effect which can also be found with 5-HT uptake inhibitors (200).

In summary, in the large bowel, gastrin has been reported to stimulate growth of both normal and neoplastic epithelium, whereas growth stimulation by 5-HT appears restricted to cancer. SRIF has been demonstrated to act as a growth inhibitor for both normal mucosa and cancer. The effect of bombesin/GRP is not clearly established, but receptors for this peptide have been demonstrated in colorectal tumors. The effect of enteroglucagon is questionable. In future studies, the search for proliferative effects induced by these substances should be guided by neurohormonal receptor assays. In view of the concept of autocrine or paracrine growth regulation, studies should be directed at neurohormones produced by endocrine tumor cells in colorectal cancer.

\subsection{Pathology of enteroendocrine cells}

\subsubsection{Hyperplasia}

Pathologic conditions of gastrointestinal ECs can be subdivided in hyperplasia and neoplasia. Hyperplasia of ECs is difficult to assess for various reasons: 1) 
ECs by definition are dispersed in gastrointestinal mucosa and therefore difficult to quantify, 2) the mucosa with EC hyperplasia may itself be atrophic or hypertrophic, and 3 ) there is a great variation in morphometric methodologies used by different investigators (201). Nevertheless, hyperplasia of ECs in the intestines has been noted in cases of celiac disease $(202,203)$, chronic ulcerative colitis (204), and radiation enteritis (205). These circumstances have in common the occurrence of chronic mucosal damage, increased turnover of the epithelium and in some instances also dysplasia and increased risk of malignancy. Hyperplasia of ECs may or may not be associated with hyperfunction of the hyperplastic cell type. It is not clear whether increased epithelial proliferation and higher levels of 5-HT in celiac disease are causally related. EC hyperplasia theoretically could be attributed to: 1) enhanced proliferation of ECs, 2) increased differentiation of precursor cells to ECs, 3) slower migration and/or maturation of ECs and 4) increased life span of ECs (201).

\subsubsection{Neoplasia}

Endocrine features in gastrointestinal tumors originally were considered to be restricted to carcinoids, which were initially described more than a century ago $(66,206)$. These tumors were recognized for their typical histological characteristics, with insular, trabecular and acinar arrangements of relatively monomorphous tumor cells, and for their relatively benign clinical behavior. Later, with further development of histochemical staining methods, the relation between carcinoids and gut ECs became clear (207). Then, "composite" tumors were recognized, consisting of combined carcinoid and acinar growth patterns, including both argyrophilia and mucus secretion (208). An example is found in the appendix, the so-called goblet-cell carcinoid (209). In the last two decennia, systematic application of histochemical, immunohistochemical and ultrastructural techniques in the study of gastrointestinal neoplasms has led to the recognition of the fact that ECs occur rather frequently in nonendocrine tumors. It now appears that a continuous spectrum of tumors exists, ranging from classical adenocarcinoma at one end, through various types of mixed exocrine-endocrine tumors, to classical carcinoids on the other end (210). Representatives of this spectrum have been described along the entire length of the digestive tract.

1- In the esophagus, ECs are extremely rare in pure squamous cell carcinoma, but combinations of small cell carcinoma with NE features and squamous cell carcinoma have been reported. In adenocarcinomas, associated with Barretts" esophagus, ECs are encountered (211). Composite or mucin-producing carcinoid tumor of the esophagus has also been reported (212).

2 - In the stomach carcinoids are relatively common, especially in connection with atrophic gastritis (213). ECs in non-endocrine gastric neoplasms occur in about 20\% of adenocarcinomas (210). Both composite tumors (214) and adenomas/adenocarcinomas with a scattered subpopulation of endocrine cells have 
been described (215). In adenocarcinomas, ECs significantly correlated with higher tumor stages (216).

3- In the small intestine, carcinoids are the most prevalent type of tumors. In these tumors, glandular differentiation and mucin production are not infrequent observations (217). Especially somatostatinomas of the duodenum can show these features (218). Goblet cell carcinoids, most frequently occurring in the appendix, occasionally are found in the duodenum (210). Although adenocarcinomas are uncommon in the small intestine and systematic search for endocrine cells in these cases has barely been performed, some reports indicate that combined endo- and exocrine differentiation is by no means rare in small intestinal cancer $(219,220)$. Moreover, in animal models, ECs are found in experimentally induced duodenal adenocarcinomas (210).

4- The appendix, together with the ileum, is the most common site for intestinal endocrine tumors. Appendiceal carcinoids have been postulated to arise from ECs in the lamina propria (61). A typical variant of classical appendiceal carcinoid is the goblet cell carcinoid (mucin-producing carcinoid, adenocarcinoid, crypt cell carcinoma), characterized by the presence of goblet cells with abundant mucin and small glandular structures with intraluminal mucin $(209,221)$. The clinical behavior of this type of tumor is intermediate between classical carcinoid and adenocarcinoma (222). In these tumors, the whole spectrum of intestinal epithelial differentiation can be encountered (223), among which so-called "amphicrine" cells, with combined exo-and endocrine features (224).

5- In the large intestine, carcinoids occur most often in the rectum, which is the part with the highest density of ECs (225). ECs occur in over $50 \%$ of adenomas $(226,227)$. The frequency of ECs in colorectal carcinomas varies from $10-30 \%$ (228-231) There are indications that carcinomas with endocrine features behave relatively poorly, although this matter is still open to discussion $(228,230,231)$. ECs occur in experimentally induced colonic carcinomas in animals (232), and occasionally also in colorectal cancer cell lines $(55,233)$.

Several patterns of combined differentiation occur in colorectal carcinomas: typical adenocarcinomas with scattered ECs (234), composite rumors combining typical adenocarcinoma and carcinoid patterns (235), diffusely infiltrating goblet cell or signet-ring cell carcinomas with argyrophilia (236), mucin-producing carcinoid tumors (237) and highly aggressive, poorly differentiated small cell carcinomas, which apart from NE features can also show exocrine and squamous differentiation (238).

The biological and clinical significance of ECs occurring in primarily non-endocrine tumors remains to be elucidated. 


\subsection{Aim of the study}

The present study focusses on endocrine differentiation in normal and neoplastic colorectal epithelium, in an attempt to elucidate the mechanisms of growth and differentiation of ECs, to evaluate growth regulation of colon tumor cells by neurohormonal substances, and to establish the clinical relevance of endocrine differentiation as a prognostic marker in colorectal adenocarcinomas. The study basically consists of three sections. The first part describes an animal model of normal intestinal EC turnover, the mid section deals with in vitro studies of colorectal cancer cells, and the final part represents an assessment of the clinical relevance of endocrine differentiation in colorectal neoplasia.

Chapter 2 describes the kinetics of renewal of enterochromaffin (5-HT producing) cells in the rat caecum, employing the thymidine analogue 5-bromo-2'deoxyuridine (BrdU), as a marker for S-phase cells, in parallel pulse-chase and continuous labeling experiments. The questions addressed in this study can be summarized as follows: 1) are enterochromaffin cells capable of proliferation? 2) are enterochromaffin cells recruited from primitive precursor cells? 3) are the pattern of renewal and turnover time of enterochromaffin cells comparable to what is known of the other epithelial cell lineages? 4) Is the preferential basal localization of enterochromaffin cells in the intestinal mucosa related to the pattern of cell renewal?

Chapters 3-6 are based on in vitro studies with cell lines derived from colorectal adenocarcinomas displaying endocrine features. In vitro models can be applied to study the factors which regulate endocrine differentiation, the position of endocrine cells in the spectrum of intestinal epithelial differentiation and the role of neurohormonal peptides in the growth regulation of colon cancer. In Chapter 3 , detailed characteristics of NCl-H716 cells, derived from a poorly differentiated human adenocarcinoma of the caecum, are described. The findings indicate that NCl-H716 cells can be used as a model to study endocrine differentiation in colorectal cancer. In Chapter 4 NCI-H716 cells are further investigated, focussing on the mechanisms governing endocrine differentiation and the hypothesis is tested that endocrine differentiation might be regulated by epithelial-stromal interactions. This hypothesis was based upon the observation that endocrine differentiation in colorectal cancer cell lines is virtually confined to tumor xenografts in vivo. The same theme is addressed in Chapter 5, in which the cell line Caco-2, representing a moderately differentiated colonic adenocarcinoma, is introduced as a model for endocrine differentiation. In this study, tumor cells transfected with a point-mutated c-Ha-ras gene, are studied with regard to tumorigenicity in immunedeficient mice and with regard to endocrine differentiation. In Chapter 6, a study regarding the presence of specific neurohormonal receptors in a number of colon cancer cell lines, growth modulation of these cells in vitro by several neurohormones, and correlation of the observed 
proliferative effects with the presence of receptors is reported. For the cell line NCI-H716, proliferation inducing effects are further analyzed by flowcytometric studies of changes occurring in various phases of the cell-cycle.

In Chapter 7, a study on the occurrence of ECs in 350 cases of colorectal adenocarcinoma by immunohistochemistry for chromogranin $\mathrm{A}$ is reported. The hormonal profile of endocrine tumor celis, the correlation between endocrine differentiation and other colorectal epithelial cell lineages within the tumors, and the prognostic relevance of endocrine differentiation in colorectal cancer are described.

Chapter 8 embodies the general discussion of the various elements of the study, the results of which are summarized in the Summary. 


\subsection{REFERENCES}

1. Silverberg E. Cancer Statistics. CA 1981;31:13.

2. Incidence of cancer in The Netherlands 1989, first report of The Netherlands Cancer Registry. Hoonte-Holland bv, Utrecht, 1992.

3. 1986 Cancer facts \& figures. American Cancer Society, New York, 1987.

4. Compendium Gezondheidsstatistiek Nederland. Centraal Bureau voor de Statistiek. 's-Gravenhage: Staatsuitgeverij, 1981.

5. Gilbert JM. Adjuvant chemotherapy of large bowel cancer. Cancer Treat Rev 1982:9:195-228.

6. Higgens GA. Current status of adjuvant therapy in the treatment of large bowel cancer. Surg Clin North Am 1983:63:137-150.

7. Mayer RJ, O'Connell MJ, Tepper JE, Wolmark N. Status of adjuvant therapy for colorectal cancer. J Natl Cancer Inst 1989;81:1359-1364.

8. Buyse M,Zeleniuch-Jacquotte A, Chalmers ThC. Adjuvant therapy of colorectal cancer. Why we still don'1 know. JAMA 1988;259:3571-3578.

9. Hesketh PJ, Bulger KN. Role of adjuvant therapy in colorectal cancer. Adv Intem Med 1991;36:219-247.

10. Morris DL, Charnley RM, Ballantyne KC, Jones J. A pilot randomized control trial of proglumide (a gastrin receptor antagonist) in advanced colorectal cancer. Eur J Surg Oncol 1990;16:423-425.

11. Manni A. Somatostatin and growth homone regulation in cancer. Biotherapy 1992;4:31-36.

12. Hermanek $P$. The relationship between surgeons and pathologists in treating cancer. Eur J Surg Oncol 1987;13:85-87.

13. Dukes CE. The classification of cancer of the rectum. J Pathol Bacteriol 1932;35:323332.

14. Blenkinsopp WK, Stewant-Brown S, Blesovsky L, Keamey G, Fielding LP. Histopathology reporting in large bowel cancer. J Clin Pathol 1981;34:598-613.

15. Arends JW, Bosman FT, Hilgers J. Tissue antigens in large bowel carcinoma. Biochim Biophys Acta 1985;780:1-19.

16. Fenoglio-Preiser CM, Lantz PE, Listrom MB, Davis M, Rilke FO. The normal anatomy of the large intestine. In: Gastrointestinal Pathology. An Atlas and Text. Raven Press, New York, 1989, pp.383-402.

17. Hamilton SR. Structure of the colon. Scand J Gastroenterol 1984;19(Supp.93):13-23.

18. Heintze K, Stewar CP, Frizzell RA. Sodium-dependent chloride secretion across rabbit descending colon. Am J Physiol 1983;244:G357-365.

19. Leblond CP, Messier B. Renewal of chief cells and goblet cells in the small intestine as shown by radioautography after injection of thymidine- ${ }^{3} \mathrm{H}$ into mice. Anat $\mathrm{Rec}$ 1958; 132:247-259.

20. Quastler H, Sheman FG. Cell population kinetics in the intestinal epithelium of the mousc. Exp Cell Res 1959;17:420-438.

21. Gratzner HG. Monoclonal antibody to 5-bromo- and 5-iododeoxyuridine: a new reagent for detection of DNA replication. Science 1982:218:474-475. 
22. Schutte B, Reynders MMJ, Bosman FT, Blijham GH. Studies with anti-bromodeoxyuridine antibodies: II Simultaneous immunocytochemical detection of antigen expression and DNA synthesis by in vivo labeling of mouse intestinal mucosa. J Histochem Cytochem 1987;35:371-374.

23. Cheng $\mathrm{H}$, Leblond $\mathrm{CP}$. Origin, differentiation and renewal of the four main epithelial cell types in the mouse small intestine. V. Unitarian theory of the origin of the four epithelial cell types. Am J Anat 1974; 141:537-562.

24. Chang WW, Leblond CP. A unitarian theory of the origin of the three populations of epithelial cells in the mouse large intestine. Anat Rec 1971;169:293.

25. Tutton PJM, Barkla DH. Regulation of cell kinetics and colon cancer. In: Experimental Colon Carcinogenesis. CRC Press, Boca Raton, Florida, 1983, pp. 199-213.

26. Lipkin M. Proliferation and differentiation of normal and diseased gastrointestinal cells. In: Physiology of the Gastrointestinal Tract. Johnson LR ed. Raven Press, New York, 1987, pp.255-284.

27. Baron DA, Miller DB. Extrusion of colonic epithelial cells in vitro. J Electron Microsc Techn 1990;16:15-24.

28. Cole JW, McKalen A. Observations of cell renewal in human rectal mucosa in vivo with thymidine- $\mathrm{H}^{3}$. Gastroenterology 1961;41:122-125.

29. Lipkin M, Bell B, Sherlock P. Cell proliferation kinetics in the gastrointestinal tract of man. I. Cell renewal in colon and rectum. J Clin Invest 1963;42:767-776.

30. Shorter RG, Moentel CG, Titus $\Omega$, Reitemeier RJ. Cell kinetics in the jejunum and rectum of man. Am J Dig Dis 1964;9:760-763.

31. Inokuchi $\mathrm{H}$, Fujimoto $\mathrm{S}, \mathrm{Kawai} \mathrm{K}$. Cellular kinetics of gastrointestinal mucosa, with special reference to gut endocrine cells. Arch Histol Jap 1983;46:137-157.

32. Patzelt V. Der Darm. In: Möllendorffs Handbuch der mikroskopischen Anatomic des Menschen. V/3. Springer-Verlag, Berlin, 1936, pp.11 l-120.

33. Deschner EE. Lipkin M. An autoradiographic study of the renewal of argentaffin cells in human rectal mucosa. Exp Cell Res 1966;43:661-665.

34. Odartchenko N, Hedinger C, Ruzicka J, Weber E. Cytokinetics of argentaffin cells in mouse intestinal mucosa. Virchows Arch B Cell Pathol 1970;6:132-136.

35. Tielemans $Y$, Håkanson R, Sundler F, Willems G. Proliferation of enterochromaftinlike colls in Omeprazole-treated hypergastrinemic rats. Gastroenterology 1989;96:723-729.

36. Chang WWL, Leblond CP. Renewal of the epithelium in the descending colon of the mouse. II Renewal of argentaffin cells. Am J Anat 1971;131:101-110.

37. Tsubouchi S, Leblond CP. Migration and tum over of entero-endocrine and caveolated cells in the epithelium of the descending colon, as shown by radiautography after continuous infusion of ${ }^{3} \mathrm{H}$-thymidine into mice. Am J Anat 1979;156:431-452.

38. Yeh KY, Yeh M, Holt PR. Induction of rat jejunal epithelial cell expression of sucraseisomaltase by glucocorticoids in primary cell culture and in vivo. Biol Cell 1989;65:1391.50 .

39. Hoosein NM, Black BE. Brattain DE, Brattain MG. Promotion of differentiation in human colon carcinoma cells by vasoactive intestinal polypeptide. Regul Pept 1989:24:15-26.

40. Koyama SY, Podolsky DK. Differential expression of transforming growth factors alpha and beta in rat intestinal epithelial cells. J Clin Invest 1989;83:1768-1773.

41. Chakrabarty S, Jan Y, Brattain MG, Tobon A, Varani J. Diverse cellular responses elicited from human colon carcinoma cells by transforming growth factor-beta. Cancer Res 1989;49:2112-2117. 
42. Menard D, Arsenault $P$, Pothier P. Biologic effects of epidermal growth factor in human fetal jejunum. Gastroenterology 1988;94:656-663.

43. Tanaka Y, Bush KK, Klauck TM, Higgins PJ. Enhancement of butyrate-induced differentiation of HT-29 human colon carcinoma cells by 1,25-dihydroxyvitamin D3. Bioclem Pharmacol 1989;38:3859-3865.

44. Donjacour AA, Cunha GR. Stromal regulation of epithelial function. Cancer Treat Res 1991;53:335-364.

45. Stallmach A, Hahn U, Merker HJ, Hahn EG, Riecken EO. Differentiation of rat intestinal epithelial cells is induced by organotypic mesenchymal cells in vitro. Gut 1989;30:959970.

46. Kedinger M, Simon-Assmann P, Haffen K. Growth and differentiation of intestinal endodermal cells in a coculture system. Gut 1987;28 Suppl:237-241.

47. Haffen K, Kedinger M, Simon-Assmann P. Mesenchyme-dependent differentiation of epithelial progenitor cells in the gut. J Pediatr Gastroenterol Nutr 1987;6:14-23.

48. Daneker GW Jr, Piazza AJ, Steele GD Jr, Mercurio AM. Interactions of human colorectal carcinoma cells with basement membranes. Analysis and correlation with differentiation. Arch Surg 1989;124: 183-187.

49. Richman PI, Bodmer WF. Control of differentiation in human colorectal carcinoma cell lines: epithelial-mesenchymal interactions. J Pathol 1988;156:197-211.

50. Hahn U, Stallmach A, Hahn EG, Riecken EO. Basement membrane components are potent promoters of rat intestinal epithelial cell differentiation in vitro. Gastroenterology 1990;98:322-335.

51. Sappino AP, Dietrich PY, Skalli O, Widgren S, Gabbiani G. Colonic pericryptal fibroblasts. Differentiation pattem in embryogenesis and phenotypic modulation in epithelial proliferative lesions. Virchows Arch A 1989;415:551-557.

52. Stallmach A, Matthes $H$, Riecken EO.Zellmembranbindungskomponenten für Bestandteile der extrazellulären Matrix: Strukturelle Vermittler der Epithelzellmatrix-Interaktion im Gastrointestinaltrakt. Z Gastroenterol 1991;29:398-403.

53. Choy MY, Richman PI, Horton MA, Mac Donald TT. Expression of the VLA family of integrins in human intestine. J Pathol 1990;160:35-40.

54. Stein B, Andrew A. Differentiation of endocrine cells in chick allantoic epithelium combined with pancreatic mesenchyme. Cell Differ Dev 1989;26:173-180.

55. Kirkland SC. Endocrine differentiation by a human rectal adenocarcinoma cell line (HRA-19). Differentiation 1986;33:148-155.

56. Lundqvist $\mathrm{M}$, Oberg $\mathrm{K}$. In vitro culture of neuroendocrine tumors of the pancreds and gut. Acta Oncol 1989;28:335-339.

57. Pearse AGE. The diffuse neuroendocrine system: falsification and verification of a concept. In: Grossman MI, Brazier MAB, Lechago J eds. Cellular basis of chemical messengers in the digestive system. Academic Press, New York, 1981, pp.13-19.

58. Falkmer $S$, Hăkanson R, Sundler F eds. Evolution and tumour pathology of the neuroendocrine system. Elsevier, Amsterdam New York Oxford, 1984.

59. Lewin KJ. The endocrine cells of the gastrointestinal tract. Part 1 . The normal endocrine cells and their hyperplasias. Pathol Annu 1986;21 Part 1:1-27.

60. Rode J, Dhillon AP, Papadaki L, Griffiths D. Neurosecretory cells of the lamina propria of the appendix and their possible relationship to carcinoids. Histopathology 1982;6:6979.

61. Auböck L, Höfler H. Extraepithelial intraneural endocrine cells as starting-points for gastrointestinal carcinoids. Virchows Arch A Pathol Anat 1983;401:17-33. 
62. Lundqvist M, Wilander E. Subepithelial neuroendocrine cells and carcinoid tumours of the human small intestine and appendix. A comparative immunohistochemical study with regard to serotonin, neuron-specific enolase and S-100 protein reactivity. J Pathol 1986; 148:141-147.

63. Buffa R, Capella C, Fontana P, Usellini L, Solcia E. Types of endocrine cells in the human colon and rectum. Cell Tissue Res 1978;192:227-240.

64. Schmidt JE. Beiträge zur normalen und pathologischen Histologie einiger Zellarten der Schleimhaut des menschliches Darmkanales. Arch mikr Anat 1905;66:12-40.

65. Masson P, Roux E. La glande endocrine de l'intestin chez l'homme. CR Acad Sci (Paris) 1914;158:59-61.

66. Obemdorfer S. Über die "kleinen Dünndarmcarcinome". Verh dtsch Ges Path 1907; 11:113-116.

67. Heidenhain R. Untersuchungen über den Bau der Labdrusen. Arch mikrosk Anal Forsch 1870;6:368-379.

68. Ciaccio C. Sur une nouvelle espèce cellulaire dans les glandes de Lieberkühn. CR SoC Biol (Paris) 1906;60:76-79.

69. Feyrter F. Über diffuse endokrine epitheliale Organe. JA Barth, Leipzig, 1938.

70. Kultschitzky N. Zur Frage über den Bau der Darmkanals. Arch mikrosk Anat Entw Mech 1897;49:7-1 1.

71. Pearse AGE. The cytochemistry and ultrastructure of polypeptide hormone-producing cells of the APUD series and the embryologic, physiologic and pathologic implications of the concept. J Histochem Cytochem 1969;17:303-313.

72. Christenson JG, Dairman W, Udenfriend S. On the identity of dopa decarboxylase and 5-hydoxytryptophan decarboxylase. Proc Natl Acad Sci USA 1972;69:343-347.

73. Solcia E, Capella C. Buffa R, Usellini L, Fiocca R, Sessa F. Endocrine cells of the digestive system. In: Physiology of the Gastrointestinal Tract. Johnson LR ed, Raven Press, New York, 1987, pp.111-130.

74. De Stephano DB, Lloyd RV, Pike AM, Wilson BS. Pituitary adenomas. An immunohistochemical study of homone production and chromogranin localization. An J Pathol 1984;116:464-472.

75. DeLellis RA, Wolfe HJ. The pathobiology of the human calcitonin (C)-cell: a review. Pathol Annu 1981;16:25-40.

76. Futrell JM, Roth SI, Su SP. Immunocytochemical localization of parathyroid hormone in bovine parathyroid glands and human parathyroid adenomas. Am J Pathol 1979:94:615-622.

77. Lloyd RV. Sisson JC, Shapira B, Verhofstad AAJ. Immunohistipchemical localization of epinephrine, norepinephrine, catecholamine synthesizing enzymes and chromogranin in neuroendocrine cells and tumors. Am J Pathol 1986;125:45-54.

78. Johnson TI. Shapiro B, Beierwaltes WH, Oringer MB, Lloyd RV, Sisson JC. Cardiac paragangliomas. A clinicopathologic and immunohistochemical study of four cases. Am J Suĩg Pathol 1985:9:827-834.

79. Gould VE, Lee I, Warren WH. Immunohistochemical evaluation of neuroendocrine cells and neoplasms of the lung. Path Res Pract 1988;183:200-213.

80. Goossens A, Heitz Ph, Klöppel G. Pancreatic endocrine cells and their non-neoplastic proliferations. In: Endocrine Pathology of the Gut and Pancreas. Dayal Yed, CRC Press, Boca Raton, Florida, 1991, pp.69-104.

81. Cecio A, Vittoria A. Urogenital paraneurons in several mammals. Arch Histol Cytol 1989;52(Suppl.):403-413. 
82. Frigerio B, Capella C, Eusebi V, Tenti P, Azzopardi JG. Merkel cell carcinoma of the skin: The structure and origin of normal Merkel cells. Histopathology 1983;7:229-249.

83. Le Douarin NM, Teillet M-A. The migration of neural crest cells to the wall of the digestive tract in avian embryo. J Embryol Exp Morphol 1973;30:31-48.

84. Andrew A. Further evidence that enterochromaffin cells are not derived from the neural crest. J Embryol Exp Morphol 1974;31:589-598.

85. Pictet RL, Ral] LB, Phelps R, Rutter WJ. The neural crest and the origin of the insulin-producing and other gastrointestinal hormone-producing cells. Science 1976;191:191-193.

86. Andrew A, Kramer B, Rawdon BB. The embryonic origin of endocrine cells of the gastrointestinal tract. Gen Comp Endocrinol 1982;47:249-265.

87. Pearse AGE. Islet development and the APUD cell concept. In: Pancreatic Pathology, Klöppel G, Heitz PU eds, Churchill Livingstone, Edinburgh, 1984, pp.125-132.

88. Sidhu GS. The endodermal origin of digestive and respiratory tract APUD cells. Am J Pathol 1979;96:5-20.

89. Ponder BAJ, Schmidt GG, Wilkinson MM, Wood MJ, Monk M, Reid A. Derivation of mouse intestinal crypts from single progenitor cells. Nature 1985;313:689-691.

90. Cox WF, Pierce GB. The endodermal origin of the endocrine cells of an adenocarcinoma of the colon of the rat. Cancer 1982;50:1530-1538.

91. Kirkland SC. Clonal origin of columnar, mucous, and endocrine cell lineages in human colorectal epithelium. Cancer 1988;61:1359-1363.

92. Pearse AGE. Genesis of the neuroendocrine system. In: Surgical Endocrinology 2nd Ed. Friesen SR, Thompson NW eds, Lippincott, Philadelphia, 1990, pp.15-22.

93. De Bruine AP, Bosman FT. Neuroendocrine tumours in the respiratory tract. Acta Histochem 1990;Suppl-Band XXXVIII:99-105.

94. Singh I. A modification of the Masson-Hamperl method for staining of argentaffin cells. Anat Anz 1964;115:81-82.

95. Erspamer V, Asero B. Identification of enteramine, the specific hormone of the enterochromaffin cell system, as 5-hydroxytryptamine. Nature 1952;169:800-801.

96. Grimelius $L$. The argyrophil reaction in islet cells of adult human pancreas studied with a new silver nitrate procedure. Acta Soc Med Upsal. 1968;73:271-294.

97. Churukian CJ, Schenk EA. A modification of Pascual's argyrophilic method. J Histotechnol 1979;2:102-103.

98. Hellerström C. Hellman B. Some aspects of silver impregnation of the islets of Langerhans in the rat. Acta Endocrinol 1960;35:518-532.

99. Sevier A, Munger BL. A silver method for paraffin sections of neural tissue. J Neuropathol Exp Neurol 1965;23:130-135.

100. Linder JE. A simple and reliable method for the silver impregnation of nerves in paraffin sections of soft and mineralized tissues. J Anat 1978;127:543-551.

101. Falk B, Hillarp NA, Thieme G, Thorp A. Fluorescence of catecholamines and related compounds condensed with formaldehyde. J Histochem Cytochem 1962;10:348-354.

102. Håkanson R, Owman C. Concomitant histochemical demonstration of histamine and catecholamines in enterochromaffin-like cells of gastric mucosa. Life Sci 1967;6:759766.

103. Solcia E, Capella C, Vassallo G. Lead-hematoxylin as a stain for endocrine colls. Significance of staining and comparison with other selective methods. Histochemie 1969;20:116-126. 
104. Solcia E, Vassallo G, Capella C. Selective staining of endocrine cells by basic dyes after acid hydrolysis. Stain Technol 1968;43:253-263.

105. Bencosme SA, Lechago J. Staining procedures for the endocrine cells of the upper gastrointestinal mucosa: light-electron microscopic correlation for the gastrin-producing cell. J Clin Pathol 1973;26:427-434.

106. Schmechel DE, Marangos PJ, Brightman M. Neurone-specific enolase is a molecular marker for peripheral and central neuroendocrine cells. Nature 1978;276:834-836.

107. Bishop AE, Polak JM, Facer P, Ferri GL, Marangos PJ, Pearse AGE. Neuron specific enolase: A common marker for the endocrine cells and innervation of the gut and pancreas. Gastroenterology 1982;83:902-915.

108. Tapia FJ, Barbosa AJA, Marangos PJ, Polak JM, Bloom SR, Dermody C, Pearse AGE. Neuron-specific enolase is produced by neuroendocrine tumors. Lancet 1981;1:808-811.

109. Carney DN, Ihde DC. Cohen MH, Marangos PJ, Bunn PA Jr, Minna JD, Gazdar AF. Serum neuron-specific enolase: A marker for disease extent and response to therapy of small-cell lung cancer. Lancet 1982;I:583-585.

110. Thompson RJ, Doran JF, Dhillon AF, Rode J. PGP 9.5 - a new marker for vertebrate neurons and neuroendocrine cells. Brain Res 1983;278:224-228.

1 11. Gulbenkian S, Wharton J, Polak JM. The visualization of cardiovascular innervation in the guinea pig using an antiserum to protein gene product 9.5. J Auto Nerv Syst 1987; 18:235-247.

112. Rode J, Dhillon AP, Doran JF, Jackson P, Thompson RJ. PGP 9.5 - a new marker for human neuroendocrine tumours. Histopathol 1985;9:147-158.

113. Wilson BS, Lloyd RV. Detection of chromogranin in neuroendocrine cells with a monoclonal antibody. Am J Pathol 1984;115:458-468.

114. Helle KB. Some chemical and physical properties of the soluble protein fraction of bovine adrenal chromaffin granules. Mol Pharmacol 1960;2:298-310.

1 15. Blaschko H, Comline RS, Schneider FH, Silver M, Smith AD. Secretion of a chromaffin granule protein, chromogranin from the adrenal gland after splanchnic stimulation. Nature 1967;215:58-59.

116. Smith AD, Winkler H. Purification and properties of an acidic protein from chromaffin granules of bovine adrenal medulla. Biochem J 1967;103:483-492.

117. Rosa P, Fumagalli G, Zanini A, Huttner WB. The major tyrosine-sulfated protein of the bovine anterior pituitary is a secretory protein present in gonadotrophs, thyrotrophs, mammotrophs and corticotrophs. J Cell Biol 1985;100:928-937.

118. Iacangelo A, Affolter HU, Eiden LE, Herbert E, Grimes M. Bovine chromogranin A sequence and distribution of its messenger RNA in endocrine tissues. Nature 1986;323:82-86.

119. Eiden LE. Is chromogranin a prohormone? Nature 1987;325:301.

120. Iacangelo $\mathrm{AL}$, Fischer-Colbrie R, Koller KJ, Brownstein MJ, Lee EE. The sequence of porcine chromogranin A messenger RNA demonstrates chromogranin A can serve as the precursor for the biologically active hormone, pancreastatin. Endocrinology 1988;122:2339-2341.

121. Bishop AE, Power RF, Polak JM. Markers for neuroendocrine differentiation. Path Res Pract 1988;183:119-128.

122. Seidah NG, Hendy GN, Hamelin J, Paquin J, Lazure C, Metters KM, Rossier J, Chrétien M. Chromogranin A can act as a reversible processing enzyme inhibitor. FEBS 1987;211:144-150. 
123. Vamdell IM, Bishop AE, Lloyd RV, Wilson BS, Grimelius L, Pearse AGE, Polak MM. Chromogranin A and Grimelius' argyrophilia. A possible correlation. Dig Dis Sci 1984;29(Suppl):935.

124. Rindi G, Buffa R, Sessa F, Tortora O, Solcia E. Chromogranin A, B and C immunoreactivities of mammalian endocrine cells. Distribution, distinction from costored hormones/prohormones and relationship with the argyrophil component of secretory granules. Histochemistry 1986;85:19-28.

125. Rosa P, Hille A, Lee RW, Zanini A, De Camilli P, Huttner WB. Secretogranins I and II: two tyrosine sulfated secretory proteins common to a variety of cells secreting peptides by the regulated pathway. J Cell Biol 1985;101:1999-2011.

126. Facer P, Bishop AE, Lloyd RV, Wilson BS, Hennessy RJ, Polak JM. Chromogranin: a newly recognized marker for endocrine cells of the human gastrointestinal tract. Gastroenterology 1985;89:1366-1373.

127. O'Connor DT, Burton D, Deftos LJ. Immunoreactive human chromogranin A in diverse polypeptide hormone producing human tumors and normal endocrine tissues. J Clin Endocrinol Metab 1983;57:1084-1086.

128. Wiedenmann B, Huttner WB. Synaptophysin and chromogranins/secretogranins - widespread constituents of distinct types of neuroendocrine vesicles and new tools in tumor diagnosis. Virchows Arch B Cell Pathol 1989;58:95-121.

129. O'Connor DT, Deftos LJ. Secretion of chromogranin A by peptide-producing endocrine neoplasms. N Engl J Med 1986;314:1145-1151.

130. Jahn R, Schiebler W, Ouimet C, Greengard P. A 38000-dalton membrane protein (p38) present in synaptic vesicles. Proc Natl Acad Sci USA 1985;82:4137-4141.

131. Navone F, Jahn R, Di Gioia G, Stukenbrok H, Greengard P, De Camilli P. Protein 38: an integral membrane protein specific for small vesicles of neurons and neuroendocrine cells. J Cell Biol 1986;103:2511-2527.

132. Rehm H, Wiedenmann B, Betz H. Molecular characterization of synaptophysin, a major calcium-binding protein of the synaptic vesicle membrane. EMBO J 1986;5:535-541.

133. Thomas L, Hartung K, Largosch D, Rehm H, Bamberg E, Franke WW, Betz H. Identification of synaptophysin as a hexameric channel protein of the synaptic vesicle membrane. Science 1988,242:1050-1053.

134. Gould VE, Lee I, Wiedenmann B, Moll R, Chejfec G, Franke WW. Synaptophysin: A novel marker for neurons, certain neuroendocrine cells and their neoplasms. Hum Pathol 1986;17:979-983.

135. Wiedenmann B, Franke WW, Kuhn C, Moll R, Gould VE. Synaptophysin: A marker protein for neuroendocrine cells and neoplasms. Proc Natl Acad Sci USA 1986;83:35003504.

136. Gould VE, Wiedenmann B, Lee I, Schwechheimer K, Dockhom-Dwomiczak B, Radosevich JA, Moll R, Franke WW. Synaptophysin expression in neuroendocrine neoplasms as determined by immunocytochemistry. Am J Pathol 1987;126:243-257.

137. Tsutsumi Y. Leu-7 immunoreactivity as histochemical marker of paraffin-embedded neuroendocrine tumours. Acta Histochem Cytochem 1984;17:15-22.

138. Tischler AS, Mobtaker H, Mann K, Nunnemacher G, Jason WJ, Dayal Y, DeLellis R, Adelman L, Wolfe HJ. Anti-lymphocyte antibody Leu-7 (HNK-1) recognizes a constituent of neuroendocrine granule matrix. J Histochem Cytochem 1986;34:1213-1216.

139. Christie AC. A study of the Kultschilzky (argentaffin) cells with the electron microscope, after fixation by osmium tetroxide. QJ Microsc Sci 1955;96:295-304. 
140. Solcia E, Pearse AGE, Grube D, Kobayashi S, Bussolati G, Creutzfeldt W, Gepts W. Revised Wiesbaden classification of gut endocrine cells. Rendic Gastroenterol 1973;5:13-16.

141. Solcia E, Polak JM, Pearse AGE, Forsmann WG, Larsson L-I, Sundler F, Lechago J, Grimelius L, Fujita T, Creutzfeldt W, Gepts W, Falkmer S, Lefranc G, Heitz P, Hage E, Buchan AMJ, Bloom SR, Grossman MI. Lausanne 1977 classification of gastroenteropancreatic endocrine cells. In: Gut Hormones. Bloom SR ed, Churchill Livingstone, Edinburgh, 1978, pp.40-48.

142. Solcia E, Creutzfeldt W, Falkmer S, Fujita T, Greider MH, Grossman MI, Grube D, Håkanson R, Larssion L-I, Lechago J, Lewin K, Polak JM, Rubin W. Human gastroenteropancreatic endocrine-paracrine cells. Santa Monica 1980 classification. In: Cellular Basis of Chemical Messengers in the Digestive System. Grossman MI, Brazier MAB, Lechago J eds, Academic Press, New York, 1981, pp.159-165.

143. Dobbins III WO, Austin LL. Electron microscopic definition of intestinal endocrine cells: immunogold localization and review. Ultrastruct Pathol 1991;15:15-39.

144. Fujita T, Kobayashi S. Structure and function of gut endocrine cells. Int Rev Cytol 1977;6(suppl): 187-233.

145. Solcia E, Capella C, Buffa R, Usellini L, Frigerio B, Fontana P. Endocrine cells of the gastrointestinal tract and related tumors. Pathobiol Annu 1979;9:163-203.

146. Wade PR, Westfall JA. Ultrastructure of enterochromaffin cells and associated neural and vascular elements in the mouse duodenum. Cell Tissue Res 1985;241:557-563.

147. Fujita T, Kobayashi S. Experimentally induced granule release in the endocrine cells of dog pyloric antrum. Z Zellforsch 1971;116:52-60.

148. Fujita T. The endocrine system of the digestive tract. In: Ultrastucture of the digestive tract. Motta PM, Fujita H eds, Martinus Nijhoff, Boston, Dordrecht, Lancaster, 1988, pp.213-228.

149. Larsson L-I, Goltermann N, De Magistris L, Rehfeld JF, Schwartz TW. Somatostatin cell processes as pathways for paracrine secretion. Science 1979;205:1393-1395.

150. Cooke HJ. Neurobiology of the intestinal mucosa. Gastroenterology 1986;90:10571081 .

I5I. Johnson LR. Regulation of gastrointestinal growth. In: Physiology of the Gastrointestinal tract, 2nd edition. Johnson LR ed, Raven Press, New York, 1987, pp.301-333.

152. McGuigan J, Isaza J, Landor J. Relationships of gastrin dose, serum gastrin, and acid secretion. Gastroenterology, 1971;61:659-666.

153. Johnson LR. New aspects of the tsophic action of gastrointestinal hormones. Gastroenterology 1977;72:788-792.

154. Johnson LR. Trophic effects of gastrin on the colon. In: Progress in Cancer Research and Therapy, Vol. 29. Wolman SR, Mastromarino A eds, Raven Press, New York, 1984, pp.327-336.

155. Ryan GP. Copeland EM, Johnson LR. Effects of gastrin or vagal denervation on DNA synthesis in canine fundic mucosa. Am J Physiol 1978;235:E565-569.

156. Takeuchi K, Peitsch W, Johnson LR. Mucosal gastrin receptor. V. Development in newbom rats. Am J Physiol 1981;240:G163-169.

157. Johnson LR, Guthrie PD. Effect of cholecystokinin and 16,16-dimethyl prostaglandin E2 on RNA and DNA of gastric and duodenal mucosa. Gastroenterology 1976;70:59-65.

158. Johnson LR, Guthrie PD. Proglumide inhibition of trophic action of pentagastrin. Am J Physiol 1984;246:G262-266. 
159. Kusyk CJ, McNiel NO, Johnson LR. Stimulation of growth of a colon cancer cell line by gastrin. Am J Physiol 1986;251:G597-601.

160. Sirinek KR, Levine BA, Moyer MP. Pentagastrin stimulates in vitro growth of normal and malignant human colon epithelial cells. Am J Surg 1985; 149:35-39.

161. Moyer MP, Armstrong A, Aust JB, Levine BA, Sirinek KR. Effects of gastrin, glutamine, and somatostatin on the in vitro growth of normal and malignant human gastric mucosal cells. Arch Surg 1986;121:285-288.

162. Singh P, Walker JP, Townsend CM, Thompson JC. Role of gastrin and gastrin receptors on the growth of a transplantable mouse colon carcinona (MC-26) in Balb/c mice. Cancer Res 1986;46:1612-1616.

163. Singh P, Le S, Beauchamp RD, Townsend CM, Thompson JC. Inhibition of pentagastrin-stimulated up-regulation of gastrin receptors and growth of mouse colon tumor in vivo by proglumide, a gastrin receptor antagonist. Cancer Res 1987;47:5000-5004.

164. Townsend CM Jr, Beauchamp RD, Singh P, Thompson JC. Growth factors and intestinal neoplasms. Am J Surg 1988; : 55:526-536.

165. Watson SA, Durrant LG, Morris DL. Growth-promoting action of gastrin on human colonic and gastric tumor cells cultured in vitro. Br J Surg 1988;75:342-345.

166. Watson S, Durrant L, Moris D. Gastrin: growth enhancing elfects on human gastric and colonic tumour cells. Br J Cancer 1989;59:554-558.

167. Watson SA, Durrant LG, Crosbie JD, Morris DL. The in vitro growth response of primary human colorectal and gastric cancer cells to gastrin. Int J Cancer 1989;43:692696.

168. Imdahl A, Eggstein S, Crone C, Farthmann EH. Growth of colorectal carcinoma cells: regulation in vitro by gastrin, pentagastrin and the gastrin-receptor antagonist proglumide. J Cancer Res Clin Oncol 1989;1 15:388-392.

169. Simopoulos C, Gaffen JD, Bennett A. Effects of gastrointestinal hormones on the growth of human intestinal epithelial cells in vitro. Gut 1989;30:600-604.

170. Hoosein NM, Kiener PA, Curry RC, Brattain MG. Evidence for autocrine growth stimulation of cultured colon tumor cells by a gastrin/cholecystokinin-like peptide. Exp Cell Res 1990;186:15-21.

171. Sasaki H, Rubalcava B, Baetens D, Blazquez E, Srikant C, Orci L, Unger R. Identification of glucagon in the gastrointestinal tract. J Clin Invest 1975;56:135-145.

172. Bell G, Sanchez-Pescador R, Layboum P, Najarian R. Exon duplication and divergence in the human preproglucagon gene. Nature 1983;303:368-371.

173. Gleeson MH, Bloom SR, Polak JM, Henry K, Dowling RH. Endocrine tumour of the kidney affecting small bowel structure, motility and absorptive function. Gut $1971 ; 12: 773-782$.

174. Sagor GR, Al-Mukhtar MYT, Ghatei MA, Wright NA, Bloom SR. Enteroglucagon and intestinal adaptation. Gut 1981;22:439-445.

175. Gornacz GE, Ghatei MA, Al-Mukhtar MYT, Yeats JC, Adrian TE, Wright NA, Bloom SR. Plasma enteroglucagon, and CCK levels and cell proliferation in defunctioned small bowel in the rat. Dig Dis Sci 1984;29:1041-1049.

176. Gregor M, Stallmach A, Menge H, Riecken EO. The role of gut-glucagon-like immunoreactants in the control of gastrointestinal epithelial cell renewal. Digestion 1990;46(suppl2):59-65.

177. Bristol JB, Ghatei MA, Smith JHF, Bloom SR, Williamson RCN. Elevated plasma enteroglucagon alone fails to alter distal colonic carcinogenesis in rats. Gastroenterology 1987;92:617-624. 
178. Saffouri B, Duval JW, Makhlouf GM. Stimulation of gastrin secretion in vitro by intraluminal chemicals: regulation by intramural cholinergic and noncholinergic neurons. Gastroenterology 1984;87:557-561.

179. Lehy T, Accary JP, Labeille D, Dubrasquet M. Chronic administration of bombesin stimulates antral gastrin cell proliferation in the rat. Gastroenterology 1983;84:914-919.

180. Spom MB, Roberts AB. Autocrine growth factors and cancer. Nature 1985;3!3:745747.

181. Radulovic SS, Milovanovic SR, Cai RZ, Schally AV. The binding of bombesin and somatostatin and their analogs to human colon cancers. Proc Soc Exp Biol Med 1992;200:394-401.

182. Brazeau P, Valc W, Burgus R, Ling N, Butcher M, Rivier J, Guillemin R. Hypothalamic polypeptide that inhibits the secretion of immunoreactive pituilary growth hormone. Science 1973; 179:77-79.

183. Boden G, Sivitz MC, Owen OT, Ersa-Koumar N, Landor JH. Somatostatin suppresses secretin and pancreatic exocrine secretion. Science 1975;190:163-165.

184. Konturek SJ, Tasler J, Cieszkowski M, Coy DH, Schally AV. Effect of growth hormone release-inhibiting hormone on gastric secretion, mucosal blood flow, and serum gastrin. Gastroenterology 1976;70:737-741.

185. Lehy T, Dubrasquet M, Bonfils $S$. Effect of somatostatin on normal and gastrin-stimulated cell proliferation in the gastric and intestinal mucosate of the rat. Digestion 1979;19:99-109.

186. Morisset J. Somatostatin: a potential antigrowth factor for the exocrine pancreas. Regul Pept 1984;10:11-20.

187. Singh P, Le S, Townsend CM, Beauchamp RD, Laridjani A, Thompson JC. A long acting somatostatin analog and prog!umide inhibit the trophic and gastrin regulatory effects of pentagastrin on mouse colon cancer cells in vivo. Gastroenterology $1986 ; 90: 1636$.

188. Palmer Smith J, Solomon TE. Effects of gastrin, proglumide and somatostatin on growth of human colon cancer. Gastroenterology 1988;95:1541-1548.

189. Schusdziarra V. Physiological significance of gastrointestinal somatostatin. Homone Res 1988;29:75-78.

190. Lamberts SWJ, Krenning EP, Reubi J-C. The role of somatostatin and its analogs in the diagnosis and treatment of tumors. Endocrine Rev 1991:12:450-482.

191. Gespach C, Emami S, Chastre E. Membrane receptors in the gastrointestinal tract. Biosci Rep 1988;8: 199-232.

192. Lopez-Ruiz MP, Arilla E. Ontogeny of somatostatin binding sites in the rabbit small intestinal epithelial tract. J Recept Res 1987;7:829-843.

193. Knuhtsen S, Esteve JP, Bernadet B, Vaysse N, Susini C. Molecular characterization of the solubilized receptor of somatostatin from rat pancreatic acinar membranes. Biochem J 1988;254:641-647.

194. Ormsbee III HS, Fondacaro JD. Action of serotonin on the gastrointestinal tract. Proc Soc Exp Biol Med 1985; 178:333-338.

195. Tutton PJM, Barkla DH. Serotonin receptors influencing cell proliferation in the jejunal crypt epithelium and in colonic adenocarcinomas. Anticancer Res 1986;6:1123-1126.

196. Tutton PJM, Barkla DH. The influence of serotonin on the mitotic rate in colonic crypt epithelium and in colonic adenocarcinoma in rats. Clin Expl Pharmacol Physiol 1978;5:91-94. 
197. Challacombe DN, Dawkins PD, Baker P. Increased tissue concentrations of 5-hydroxytryptamine in the duodenal mucosa of patients with coeliac disease. Gut 1977;18:882886.

198. Wheeler $E E$, Challacombe DN. Influence of 5-hydroxytryptamine on crypt cell production rate of human duodenal mucosa cultured in vitro. J Clin Pathol 1987;40:710-713.

199. Drews M. Morphological and functional evaluation of enterochromaffin cells in the remaining small intestine after massive resection in rats. In: Mechanisms of Intestinal Adaptation. Robinson JWL, Dowling RH, Riecken E-O eds, MTP Press Ltd., Lancaster, 1982, p.397.

200. Tutton PJM, Barkla DH. Biogenic amines as regulators of the proliferative activity of normal and neoplastic intestinal epithelial cells. Anticancer Res 1987:7:1-12.

201. Dayal Y, DeLellis RA, Wolfe HJ. Hyperplastic lesions of the gastrointestinal endocrine cells. Am J Surg Pathol 1987;11(Suppl 1):87-101.

202. Challacombe DN, Robertson K. Enterochromaffin cells in the duodenal mucosa of children with coeliac disease. Gut 1977; 18:373-376.

203. Sjölund K, Alumets J, Berg N-O, Håkanson R, Sundler F. Enteropathy of celiac disease in adults: increased number of enterochromaffin cells in the duodenal mucosa. Gut 1982;23:42-48.

204. Gledhill A, Hall PA, Cruse JP, Pollock DJ. Enteroendocrine cell hyperplasia, carcinoid tumors and adenocarcinoma in long-standing uicerative colitis. Histopathology 1986; 10:501-508.

205. Pietroletti R, Blaauwgeers JLG, Taat CW, Simi M, Brummelkamp WH, Becker AE. Intestinal endocrine cells in radiation enteritis. Surg Gynecol Obstet 1989;169:127-130.

206. Lubarsch O. Über den primären Krebs des Ileum nebst Bemerkungen über das gleichzeitige Vorkommen des Krebs und Tuberculose. Virchow Arch 1888;111:281290.

207. Gosset H, Masson P. Tumeur endocrine de l'appendice. Presse Med 1914;25:237-248.

208. Morson BC, Sobin LH. Histological typing of intestinal tumors. World Health Organization, Geneva, 1976.

209. Subbuswamy SG, Gibbs NM, Ross CF, Morson BC. Goblet cell carcinoid of the appendix. Cancer 1974;34:338-344.

210. Bosman FT, De Bruine A. Endocrine cells in nonendocrine tumors of the gut and pancreas. In: Endocrine Pathology of the Gut and Pancreas. Dayal Y ed, CRC Press, Boca Raton, Florida, 1991, pp.319-338.

211. Banner BF, Memoli VA, Warren WH, Gould VE. Carcinoma with multidirectional differentiation arising in Barrett's esophagus. Ultrastruct Pathol 1983;4:205-214.

212. Chong FR, Graham JH, Madoff IM. Mucin producing carcinoid (composite tumour) of the upper third of the esophagus. Cancer 1979;44:1853-1859.

213. Borch K, Renvall H, Liedberg G. Gastric endocrine cell hyperplasia and carcinoid tumors in pernicious anemia. Gastroenterology 1985;88:638-648.

214. Ulich TR, Kollin M, Lewin KJ. Composite gastric carcinoma. Report of a tumor of the carcinoma-carcinoid spectrum. Arch Pathol Lab Med 1988;1 12:91-93.

215. Bonar SF, Sweeney EC. The prevalence, prognostic significance and hormonal content of endocrine cells in gastric cancer. Histopathology 1986;10:53-63.

216. Ooi A, Mai M, Ogino T, Ueda H, Kitamura T, Takahashi Y, Kawahara E, Nakanishi I. Endocrine differentiation of gastric adenocarcinoma. The prevalence as evaluated by immunoreactive chromogranin A and its biologic significance. Cancer 1988;62:10961104. 
217. Ratzenhofer M. Hyperplasias and tumors of the disseminated endocrine (paracrine) Helle Zellen Feyrter's of the gut with special regard of amphicrine cell proliferations. In: Verh Dtsch Ges Pathol, 61 Tagg Erlangen, Gustav Fischer, Stuttgart New York, 1977, pp.7-24.

218. Griffith DFR, Jasani B, Newman GR, Williams ED, Williams GT. Glandular duodenal carcinoid - a somatostatin rich tumour with neuroendocrine associations. J Clin Pathol 1984;37:163-169.

219. Lundqvist M, Wilander E. Exocrine and endocrine cell diffentiation in small intestinal adenocarcinomas. Acta Pathol Microbiol Immuno Scand A 1983;91:469-474.

220. Lien GS, Mori M, Enjoji M. Primary carcinoma of the small intestine. A clinicopathological and immunohistochemical study. Cancer 1988;61:316-323.

221. Rodriguez FH, Sarma DP, Lunseth JH. Goblet cell carcinoid of the appendix. Hum Pathol 1982; 13:286-288.

222. Bak M, Jorgensen LJ. Adenocarcinoid of the appendix presenting with metastases to the liver. Dis Colon Rectum 1987;30:112-115.

223. Isaacson P. Crypt cell carcinoma of the appendix (so-called adenocarcinoid tumor). Am J Surg Pathol 1981;5:223-224.

224. Höfler H, Klöppel G, Heitz PU. Combined production of mucus, amines and peptides by goblet-cell carcinoids of the appendix and ileum. Pathol Res Pract 1984;178:555-561.

225. Sjölund K, Sandén G, Håkanson R, Sundler F. Endocrine cells in the human intestine: an immunocytochemical study. Gastroenterology 1983;85:1120-1130.

226. Van den Ingh HGFM, Van den Broek LJ, Verhofstad AAJ, Bosman FT. Neuroendocrine cells in colorectal adenomas. J Pathol 1986;148:231-237.

227. Iwashita A, Watanabe H, Enjoji M. Argyrophil and argentaffin cells in adenomas of the colon and rectum. Fukuoka Igaku Zasshi 1989;80:114-124.

228. Arends JW, Wiggers T, Verstijnen C, Bosman FT. The occurrence and clinicopathological significance of serotonin immunoreactive cells in large bowel carcinoma. J Pathol 1986; 149:97-102.

229. Iwashita A. Argyrophil and argentaffin cells in carcinomas of the colon and rectum. Fukuoka Acta Med 1979;70:370-390.

230. Smith DM, Haggitt RC. The prevalence and prognostic significance of argyrophil cells in colorectal carcinomas. Am J Surg Pathol 1984;8:123-128.

231. Hamada $Y$, Oishi A, Shoji T, Takada H, Yamamura M, Hioki K, Yamamoto M. Endocrine cells and prognosis in patients with colorectal carcinoma. Cancer 1992;69:2641-2646.

232. Shimamoto F, Tahara E, Yanaihara N. Gut endocrine cells in rat intestinal-tract carcinoma induced by 1,2-dimethylhydrazine. J Cancer Res Clin Oncol 1983;105:221-230.

233. Park J-G, Oie HK, Sugarbaker PH, Henslee JG, Chen T-R, Johnson BE, Gazdar A. Characteristic of cell lines established from human colorectal carcinoma. Cancer Res 1987;47:6710-6718.

234. Ulich TR, Cheng L. Glover H, Yang K, Lewin KJ. A colonic adenocarcinoma with argentaffin cells. An immunoperoxidase study demonstrating the presence of numerous neuroendocrine products. Cancer 1983,51:1483-1498.

235. Moyana TN, Qizilbash AH, Murphy F. Composite glandular-carcinoid tumors of the colon and rectum. Report of two cases. Am J Surg Pathol 1988;12:607-611.

236. Kubo T, Watanabe $H$. Neoplastic argentaffin cells in gastric and intestinal carcinomas. Cancer 1971;27:447-454. 
237. Hemandez F, Fernandez BB. Mucus-secreting colonic carcinoid tumors. Dis Colon Rectum 1974;17:387-396.

238. Damjanov I, Amenta PS, Bosman FT. Undifferentiated carcinoma of the colon containing exocrine, neuroendocrine and squamous cells. Virchows Arch A Pathol Anat 1983;401:57-66.

239. Dayal Y. Neuroendocrine cells of the gastrointestinal tract: introduction and historical perspective. In: Endocrine Pathology of the Gut and Pancreas. Dayal Y ed, CRC Press, Boca Raton, Florida, 1991, pp.1-31. 



\section{CHAPTER 2}

\section{RENEWAL OF ENTEROCHROMAFFIN CELLS IN THE RAT CAECUM}

A.P. de Bruine, W.N.M. Dinjens, J.H.L. Zijlema, M.-H. Lenders, and F.T. Bosman

The Anatomical Record 1992;233;75-82.

(reprinted with permission) 


\subsection{INTRODUCTION}

The diffuse neuroendocrine system is a complex of endocrine cells, widely distributed in numerous tissues and organs, including the gastrointestinal and respiratory tracts. The cells are usually localized in the epithelial compartment, either solitary or in more or less clearly defined clusters. In the intestines, the so called enteroendocrine cells are preferentially situated in the basal crypt regions, although to a lesser extent they also occur in a more superficial position (1). Numerous studies have focussed on the morphology, localization and neurohormonal peptide content of enteroendocrine cells. These studies have contributed to the understanding of the role of the enteroendocrine cell in the regulation of gastrointestinal growth and function $(2,3)$. However, little is known about the lifespan and renewal of these cells (4). Also, it remains unclear whether the endocrine cells are a relatively isolated cell lineage or, altematively, have a differentiation pathway in common with the other epithelial cell types. Knowledge of endocrine cell-kinetics in the digestive tract may contribute to better understanding of intestinal mucosal growth and differentiation in both normal and pathologic circumstances. In a variety of intestinal conditions endocrine cells appear to be involved. For instance, when metaplasia occurs in gastrointestinal epithelium, the component of endocrine cells is altered according to the type of metaplastic epithelium (5). This points to a common origin of the various epithelial components, a notion which is supported by differentiation patterns in intestinal neoplasms. Endocrine differentiation is by no means rare in gastrointestinal curcinomas and endocrine cells form an integral part of a carcinoma (6). The number of intestinal endocrine cells can increase in cases of celiac disease, ulcerative colitis, Crohn's disease and radiation enteritis, all characterized by chronic mucosal damage and ensuing regeneration $(4,7)$. The cause of endocrine cell hyperplasia under the latter circumstances is not clear, but might be related to increased cell turnover or decreased maturation.

Relatively few cell-kinetic studies have been performed in the colon. In connection with our interest in colon cancer and endocrine differentiation in colorectal carcinoma, we chose to study the renewal of endocrine cells in the rat caecum. In rodents, the caecum is a fairly well developed, easily identifiable part of the colon, of great importance for the digestive process, on account of its role in metabolizing complex carbohydrates, which form a major part of the diet (8). Current knowledge on the kinetics of gut endocrine cells mainly concerns serotonin producing or enterochromaffin cells (EC cells) (9). These cells together contain the largest bodily supply of this important neurotransmitter (10) and represent the single largest fraction of enteroendocrine cells (11), occurring along the entire length of the digestive tract. Kinetic studies so far have employed combinations of tritiated thymidine ( ${ }^{3} \mathrm{H}$-thymidine) autoradiography and conventional histochemical identification methods. We elected to use combined 
immunohistochemical detection of serotonin (5-HT) and 5-bromo-2'-deoxyuridine (BrdU) for analysis of the renewal of EC cells.

In this study we attempted to answer the following questions: 1) Are EC cells capable of proliferation? 2) Are EC cells recruited from primitive precursor cells? 3) Are the pattern of renewal and turnover time of EC cells comparable to what is known of the other epithelial cell lineages? 4) Is the preferential basal localization of EC cells in the intestinal mucosa related to the pattern of cell renewal?

\subsection{MATERIALS AND METHODS}

\subsubsection{Experimental Design}

Renewal of EC cells was studied by labeling DNA synthesizing cells with the thymidine analogue $\mathrm{BrdU}$, which is incorporated in replicating nuclei during the $\mathrm{S}$-phase of the cell-cycle (12). In a time-course experiment, combining pulse labeling and continuous labeling, EC cell turnover was analyzed through changes in labeling index (LI, the percentage of labeled EC cells). Also, the disappearance of labeled EC cells from the mucosa was monitored at two points after termination of labeling. The LI of labeled EC cells was determined for the whole population and for the upper and lower crypt segments separately. The LI directly after administering the pulse label demonstrates whether EC cells are capable of proliferation. Changes in the LI and localization of labeled EC cells after pulse-labeling supply information on possible recruitment and migration. Continuous labeling for a sufficient period of time allows determination of the turnover time of the population and of the percentage of cells participating in the process of renewal.

\subsubsection{Animals}

54 inbred female Sprague-Dawley rats (Charles River Wiga, Sulzfeld, Germany) were used, weighing 250-350 grams and aged 22-36 weeks, depending on the duration of the experiment. They were randomly assigned to groups of three animals for each labeling period. The animals were housed separately in perspex wire-topped cages, with standard laboratory food and tap-water ad libitum, constant ambient temperature of $20-22^{\circ} \mathrm{C}$ and alternating periods of artificial light and darkness (LD 12:12 with light from 0600 to 1800 hours).

\subsubsection{Labeling Experiments}

A solution of BrdU (Serva, Heidelberg, Germany) was administered either as a single bolus or continuously. Continuous labeling was done with ALZET miniosmotic pumps (ALZA, Palo Alto, California USA) type 2001 (capacity $200 \mu \mathrm{l}$, 
standard deliverance $1 \mu \mathrm{l}$ /hour for 7 days) or type 2002. (capacity $200 \mu \mathrm{l}$, standard deliverance $0.5 \mu \mathrm{l} /$ hour for 14 days).

BrdU was dissolved in phosphate buffered saline (PBS) in concentrations of 30 $\mathrm{mg} / \mathrm{ml}$ (pulse and type 2001) or $60 \mathrm{mg} / \mathrm{ml}$ with $0.75 \%$ NH3 (type 2002), and subsequently sterilized by means of a sterile pyrogen free microfilter.

For pulse-labeling $0.5 \mathrm{ml}$ of the least concentrated solution, equalling a dose of approximately $50 \mathrm{mg} / \mathrm{kg}$ bodyweight, was given by intraperitoneal injection under light ether anaesthesia. The mini-osmotic pumps were filled with the appropriate solution and placed subcutaneously in the neck-region, also under light anaesthesia, by semi-sterile operating conditions. Prior to implantation of the pumps they were kept in sterile isotonic saline at $37^{\circ} \mathrm{C}$ for at least 4 hours, to reach a steady state pumping value. Pumps were replaced as often as needed to sustain a constant release during the labeling period.

To avoid diurnal variation, pulse labeling was always performed around $10 \mathrm{a} . \mathrm{m}$., and the pumps were consistently implanted around 1 p.m..

After pulse-labeling, animals were sacrificed at the following time points: 1, 12, 24, 48, 96 and 192 hours. For the continuous labeling experiment, the same intervals were chosen, with the exception of the 1 hour period, and additional groups were terminated after continuous labeling for 16, 25, 31 and 73 days. To study the loss of labeled EC cells from the mucosa, three separate animals were continuously labeled for 31 days and, after removal of the pumps, were sacrificed 4,8 and 16 days following the end of the labeling period. Similarly, two groups of three animals labeled during 73 days were sacrificed 16 and 30 days after removal of the pumps.

\subsubsection{Tissue sampling}

Animals were exsanguinated by aortic puncture after opening of the abdomen through a mid-line incision under deep ether anaesthesia.

The colon was removed, carefully opened and gently cleaned from faecal contents by rinsing in ice-cold PBS.

The caecum was pinned onto a piece of cork covered with filterpaper, with the mucosa upwards. The tissue was fixed in freshly prepared phosphate buffered $10 \%$ formalin at $4^{\circ} \mathrm{C}$ for a maximum of 12 hours.

Tissue was routinely processed and embedded in paraffin. Sections were cut at $2 \mu \mathrm{m}$ thickness, and mounted on chromalum-gelatin coated glass slides.

\subsubsection{Immunohistochemistry}

To visualize the enterochromaffin cells and to assess the labeling index of these cells at the same time, a double indirect immunofluorescence procedure was applied.

Briefly, after deparaffinization in xylene and rehydration in graded ethanol series, the sections were pretreated with pepsin $0.04 \%$ in $0.1 \mathrm{~N} \mathrm{HCl}(30 \mathrm{~min}$., 
$\mathrm{RT}$ ) and, after thorough rinsing in PBS, were immersed in $2 \mathrm{~N} \mathrm{HCl}$ (30 min., $37^{\circ} \mathrm{C}$ ), to obtain single-stranded DNA for presentation of the antigenic BrdU sites (13). Subsequently, the $\mathrm{pH}$ was neutralized by washing in sodium tetraborate $(\mathrm{pH} 8.5)$ and $\mathrm{PBS}$, and the sections were preincubated (10 min., RT) with $20 \%(\mathrm{v} / \mathrm{v})$ normal goat serum.

Following this, the sections were incubated $\left(1 \mathrm{hr} ., 37^{\circ} \mathrm{C}\right)$ with a mixture of rabbit-anti-serotonin antiserum and an anti-BrdU mouse-monoclonal antibody. The serotonin antiserum was raised in our laboratory by immunizing rabbits with serotonin-ovalbumin conjugate. The titre and specificity of the antiserum were assayed by solid phase enzyme immunoassay as described previously (14). In this test system the antiserum was highly specific for serotonin. The antiBrdU antibody was also prepared in our laboratory and has been described previously (13).

After washing in PBS the sections were incubated $\left(1 \mathrm{hr} ., 37^{\circ} \mathrm{C}\right)$ with a combination of goat anti-rabbit IgG-fluorescein isothiocyanate (FITC, Nordic, the Netherlands) and goat anti-mouse IgG-tetramethyl rhodamine isothiocyanate (TRITC, TAGO, Burlingame, USA). Finally, the sections were washed in distilled water and mounted in UV-resistant mounting medium (UV Inert, BDH Gurr, England). As negative control for serotonin, parallel sections were incubated with normal rabbit serum instead of the anti-serotonin antibody, and for BrdU the primary antibody was omitted or was applied without prior denaturation of DNA. Negative controls were consistently negative.

\subsubsection{Determination of Labeling Indices}

By fluorescence microscopy, EC cells and BrdU-positive or -negative nuclei could clearly be visualized (Colorplate 1, page 81 ).

Scoring was performed as follows. Serotonin containing cells were localized in longitudinally sectioned crypts. Nuclei of all EC cells, including open type and closed type cells, were counted as positive or negative for BrdU. The number of EC cells in the upper or lower crypt segment was determined. The boundary between upper and lower crypt segment was established using a calibrated eyepiece and was chosen as the point exactly halfway between muscularis mucosae and surface epithelium. In the rare occasion that an EC cell was precisely in the middle of the cryptcolumn, it was alternately counted as lower or upper.

All slides were encoded prior to examination. In every animal at least $240 \mathrm{EC}$ cells were counted in two or more different, non-serially cut sections. Two observers took part in the scoring and regularly checked interobserver variation by counting the same section; this never exceeded 6 percent.

For each group of 3 animals, representing a certain timepoint, the mean LI and standard deviation were determined. This was done for the total population of EC cells and for upper and lower crypt halves separately. 


\subsubsection{Statistics}

Data were statistically analyzed by t-tests for independent groups with separate variances. Whenever the F-test (Fisher-Snedecor) of equal variances was rejected at $\alpha$ of 0.05 , a Mann-Whitney test was performed.

\subsubsection{Histochemical Control Experiments}

In the rat intestines also serotonin containing mucosal mast cells occur (15). Therefore, in consecutive sections we compared serotonin-immunohistochemical staining patterns with the pattern obtained by staining with $0.5 \%$ toluidine blue at $\mathrm{pH} 0.5$ ( 5 days), which stains mucosal mast cells (16).

To discover which proportion of enteroendocrine cells could be identified by our immunohistochemical approach, we stained serial sections immunohistochemically for serotonin and histochemically with the argyrophil silver impregnation technique of Grimelius (17).

To find out whether any changes in crypt cell proliferation had been induced by long term administration of BrdU, the animals from the group labeled continuously for 73 days received a pulse dose of $0.75 \mu \mathrm{Ci} / \mathrm{kg}$ of ${ }^{3} \mathrm{H}$-thymidine (New England Nuclear, s.a. $1 \mathrm{Ci} / \mathrm{mmol}$ ) i.p. half an hour prior to termination. Autoradiography was performed on $2 \mu \mathrm{m}$ sections of caecum. The slides were covered with Ilford K2 emulsion (Ilford, UK) and developed after 3 weeks of exposure with D76 (Kodak). Nuclei were counterstained with haematoxylin. Total number of nuclei and the number of labeled nuclei in longitudinally sectioned crypts were counted.

Our crypt cell model presupposes that the upper and lower crypt-cell compartments contain an equal number of ceils. To test this, in 5 experimental animals the number of cells in the upper and lower half of 10 longitudinally sectioned $(1 \mu \mathrm{m})$ crypts was counted, starting from the mid-part of the cryptbase, going up along the right side of the crypt and ending with the surface epithelium exactly between two adjacent crypts.

\section{$2.3 \quad$ RESULTS}

\subsubsection{Histochemical Control experiments}

Staining of sequential sections for mucosal mast cells and serotonin showed that there was no overlap between mucosal mast cells and EC cells, which is consistent with the literature (18). The majority of mast cells occurred in the lamina propria, and few intraepithelial mast cells were mainly localized superficially in the epithelial lining.

Grimelius staining showed more than $95 \%$ of the argyrophil cells to be immunoreactive for serotonin. EC cell distribution was remarkably constant, with 

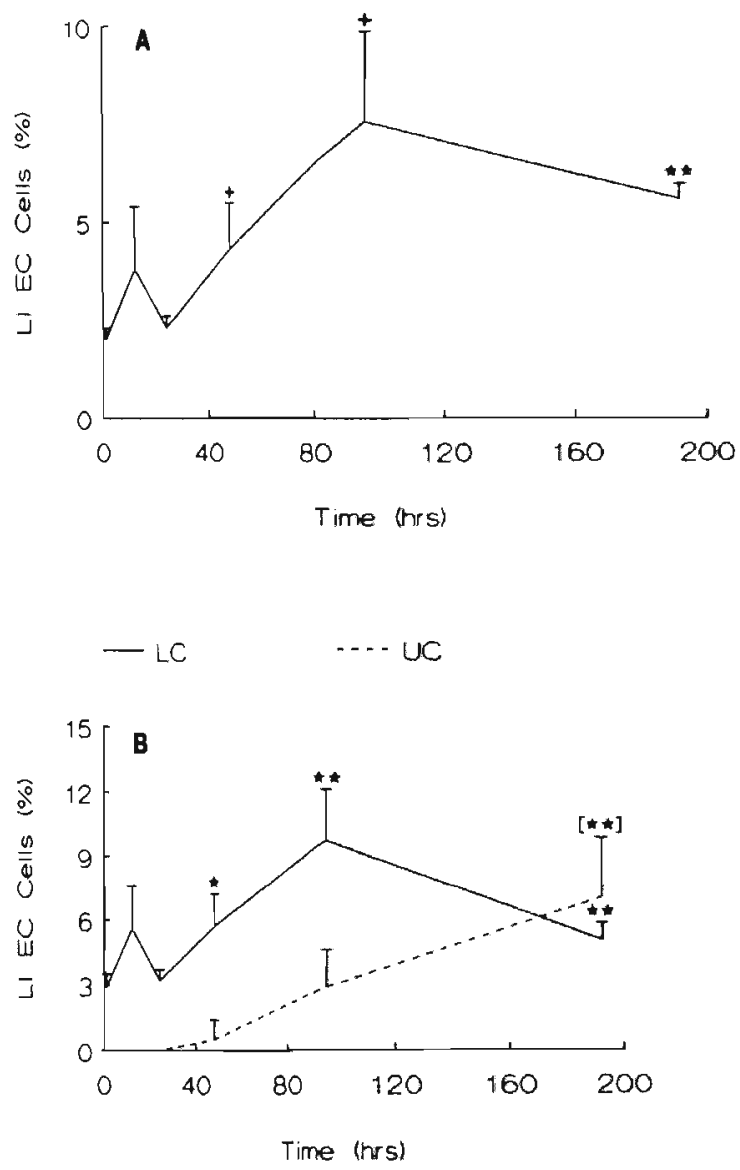

Figure 1. BrdU-LI of EC cells as a function of time in the pulse-chase experiment (mean and std for each timepoint, $n=3$ ). a. LI for the whole population of EC cells. ${ }^{* *}=p<0.05$ (t-test), $+=p<0.1$ (Mann-Whitney), vs. $\mathrm{t}=1 \mathrm{hr} . \mathrm{b} . \mathrm{LI}$ for EC cells in LC and UC separately. ${ }^{* *}=\mathrm{p}<0.05,{ }^{*}=\mathrm{p}<0.1$ (t-test) vs. $\mathrm{t}=1 \mathrm{hr}$. and $\left.{ }^{* *}\right]=\mathrm{p}<0.05$ (t-test) vs. $\mathrm{t}=48 \mathrm{hrs}$.

approximately $70 \%$ in the lower and $30 \%$ in the upper crypt segment, both segments containing an equal total number of epithelial cells.

The percentage and distribution of ${ }^{3} \mathrm{H}$-thymidine labeled crypt cells in rats treated for 73 days with BrdU did not differ from that observed in animals initially receiving a pulse dose of BrdU. In both, the LI was approximately $15 \%$ and labeled cells were only found in the lower crypt half (data not shown). 
These results indicate that our histochemical approach is reliable and that BrdU does not significantly influence the proliferative behavior of intestinal epithelial cells.

\subsubsection{Pulse-chase experiment}

The LI of EC cells one hour after flash labeling with BrdU was found to be $2.0 \%$, which represents the number of EC cells in S-phase, implying that a small portion of EC cells in the rat caecum is capable of self-replication. As is shown in Figure 1a, the LI increased to a maximum of $7.6 \%$ at $96 \mathrm{~h}$ (with a transient wave in the first $24 \mathrm{~h}$ ). In the lower crypt half the LI increased to $10 \%$ at $96 \mathrm{~h}$, but in the upper crypt half labeled cells did not appear until $48 \mathrm{~h}$, gradually increasing to a level of $7.0 \%$ after 192 hours. This increment continued while the percentage of labeled cells in the lower crypt half was already decreasing (Fig. 1b).

\subsubsection{Continuous labeling experiment}

As shown in Figure 2a, continuous labeling resulted in a gradual linear increase of the LI to approximately $65 \%$ after 16 days. Then the increment leveled off to reach $80 \%$ after 73 days.

As in the pulse-chase experiment, labeling commenced in the lower half of the mucosal crypt, followed by the upper crypt half after $24-48$ hours of labeling. Subsequently the rise in labeled cells for both parts of the crypt showed a gradual increase and followed a parallel course (Fig. 2b).

The LI leveled off at the same timepoint for both the lower and upper crypt half, but at different heights: the $\mathrm{LI}$ for the lower crypt half at this point was $65-70 \%$, for the upper half $45-55 \%$. After 73 days of continuous labeling, the LI in the lower crypt half was still higher than in the upper part of the crypts ( $84 \%$ vs. $71 \%)$.

\subsubsection{Loss of labeled EC cells}

4 days after continuous labeling for 31 days, the LI of EC cells was 65\%. Subsequently an almost linear decline in LI took place to $3.5 \%$ after 16 days (Fig. 3a). The LI in the lower mucosal half exceeded that of the upper half until day 16 , when the $\mathrm{LI}$ in the upper crypt half was $5 \%$ versus $2.6 \%$ in the lower half (Fig. 3b).

The loss of labeled EC cells after labeling for 73 days is shown in Figure 4a. A biphasic decline was found, the LI decreasing to $8.0 \%$ after 16 days and to $1.6 \%$ after 30 days. The $L I$ in the upper crypt half consistently remained higher than in the lower crypt half (Fig. 4b). 

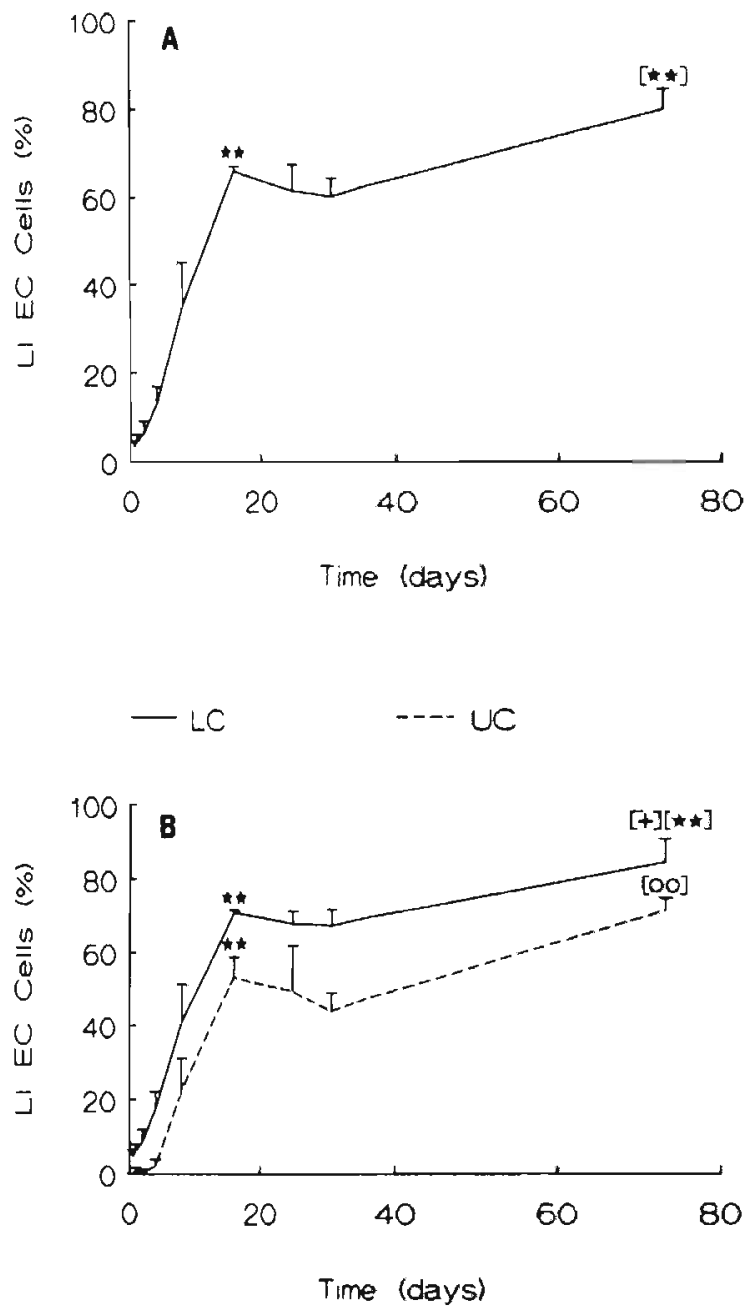

Figure 2. BrdU-LI of EC cells as a function of time in the continuous labeling experiment (mean and std for each timepoint, $\mathrm{n}=3$ ). a. LI for the whole population of EC cells. ${ }^{* *}=p<0.05$ vs. $\mathrm{t}=0.5$ day, $\left.{ }^{* *}\right]=\mathrm{p}<0.05$ vs. $\mathrm{t}=16,25$ and 31 days $(\mathrm{t}$-test). $\mathbf{b}$. $\mathrm{LI}$ for EC cells in LC and UC separately. ${ }^{* *}=p<0.05$ (t-test), vs. $t=0.5$ day; $\left[{ }^{* *}\right]=p<0.05$ (t-test) vs, $t=25$ and 31 days, $[+]=p<0.1$ (MannWhitney) vs, $t=16$ days; $[00]=p<0.05$ vs. $t=16,25$ and 31 days (t-test). 

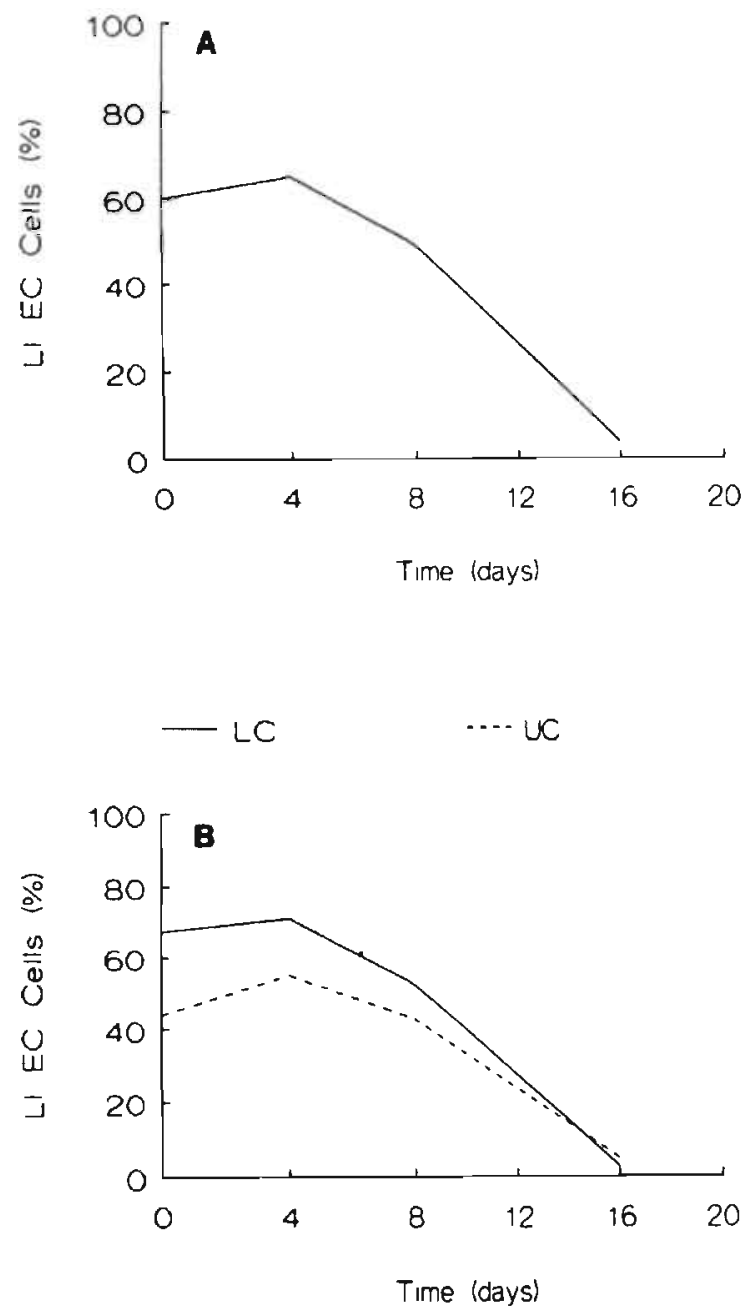

Figure 3. Decrease of BrdU-LI of EC cells as a function of time after continuously labeling for 31 days ( $n=1$ for each timepoint). a. LI for the whole population of EC cells. b. LI for EC cells in LC and UC separately. 


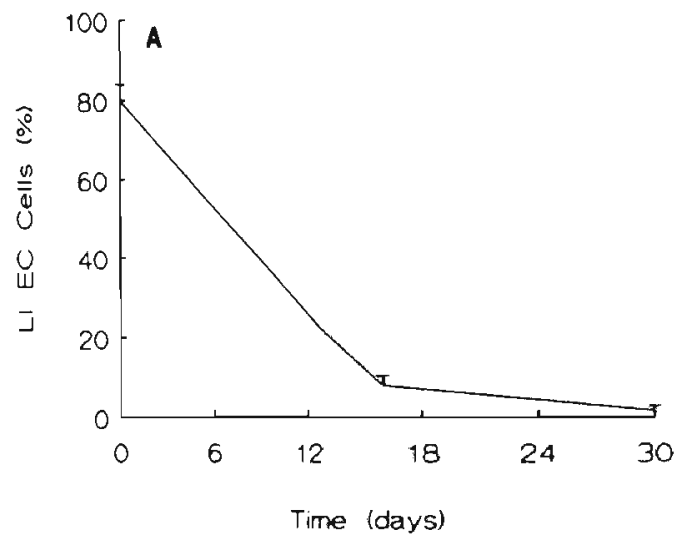

- LC $\quad \cdots \cup$

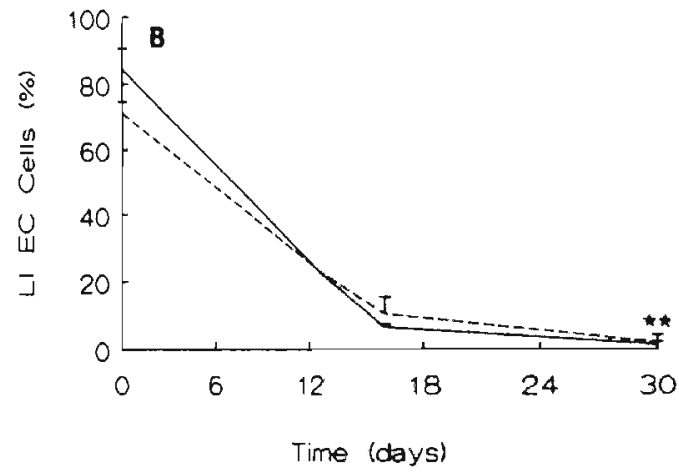

Figure 4. Decrease of BrdU-LI of EC cells as a function of time after continuously labeling for 73 days (mean and std for each timepoint, $n=3$ ). a. LI for the whole population of EC cells. b. LI for EC cells in LC and UC separately. ${ }^{* *}=p<0.05$ (t-test) vs. $t=16$ days for LC; $n . s$. for UC and the whole population ( $p<0.05$ for all observations vs. $t=0$ days). 


\subsection{DISCUSSION}

The colonic crypt epithelium is considered to be renewed by proliferation in the basal parts of the crypts and subsequent migration of newly formed epithelial cells towards the surface, with concomittant differentiation. Conceivably, differentiating cells might retain proliferative capability until terminally differentiated.

The LI of $2 \%$ one hour after BrdU administration indicates that a minor portion of EC cells has self-replicative capacity. This does not only apply to the large intestine. Our group previously demonstrated similar low labeling indices of serotonin-, gastrin-and somatostatin immunoreactive cells in rat gastric and duodenal mucosa (19). Furthermore, mitotic activity in endocrine cells has been reported $(20,21)$.

The rise in LI of EC cells between 1 and 96 hours (Fig. la), after a BrdU pulse, can be explained by recruitment from undifferentiated precursor cells, which were in S-phase at the moment of pulse-labeling. The relatively sharp increase in LI especially in the lower crypt half (Fig. Ib), indicates that, as expected, these immature precursors are located in the basal crypt regions. This is also supported by the phase difference in labeling of EC cells between lower and upper crypt half (Fig. 1b), which indicates that renewal of EC cells is initiated in the lower part of the mucosal crypt and that these cells migrate towards the mucosal surface.

The EC cell population must remain in a dynamic steady state, in which every lost EC cell is replaced by a newly formed EC cell. By continuous labeling, one would expect a linear increase of the LI, lasting until practically all EC cells are labeled. The bifasic pattem which was observed (Fig. 2a) can be explained by assuming that there are at least two kinetically distinct subpopulations of EC cells, as is schematically shown in Figure 5. One of these represents a fairly rapidly renewing fraction of $60-65 \%$ of the EC cell population, reaching its maximum LI and therefore having a renewal time of 16 days at the most; the other is a relatively slowly renewing fraction, consisting of about $35-40 \%$ of the EC cells with a renewal time of approximately 150 days. The possibility of two kinetically distinct subpopulations of enteroendocrine cells has been considered previously $(22,23)$.

Studying the loss of labeled EC cells from the mucosa supports this notion. The remaining $3.5 \%$ of labeled EC cells (Fig. 3 a) 16 days after continuous labeling for 31 days, presumably belongs to the compartment of slowly renewing cells, because the rapidly renewing cells would have been replaced at this point. This $3.5 \%$ represents about $10 \%$ of the whole population $(35-40 \%)$ of slowly renewing EC cells. Theoretically the LI of slowly renewing EC cells would be $20 \%$ after 31 days of continuous labeling, which would result in a renewal time of 


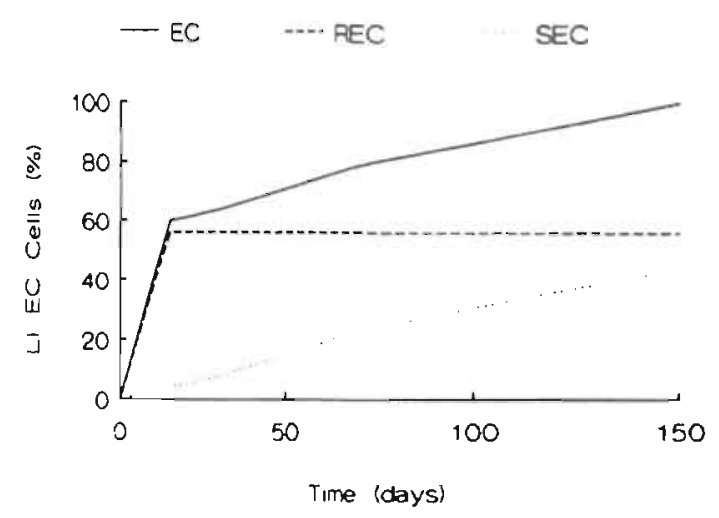

Figure 5. Hypothetical renewal of rat caecal EC cells (EC), assuming a relatively rapidly (REC) and relatively slowly (SEC) renewing fraction.

approximately 155 days for the whole population of slowly renewing EC cells, as was also estimated from the continuous labeling experiment.

Similar inferences can be derived from studying the loss of labeled EC cells after continuous labeling for 73 days. The decline of the LI is biphasic, comparable to the increase during continuous labeling (Figs. $4 \mathrm{a}$ and $4 \mathrm{~b}$ ).

Summarizing the three labeling experiments, renewal of EC cells in the rat caecum is a combination of self-replication and recruitment from proliferating precursor cells, not (yet) belonging to the endocrine lineage. The population of newly formed endocrine cells is subject to migration from basal parts of the intestinal crypts towards the mucosal surface, where they probably die and are shed into the gut lumen. In these aspects endocrine cells do not fundamentally deviate from the other crypt-cell lineages. They do differ in the slower rate of cell tumover, which for other cell types has been reported to take 2 to 4.6 days $(9,24)$. In this experiment, labeling of caecal crypt cells approached $100 \%$ after continuous labeling for 96 hours.

The EC cell population in the rat caecum remains in a steady state, in which always approximately $70 \%$ of the cells is located in the lower crypt half and $30 \%$ in the upper part of the crypts. This pattern is surprising, given a constantly renewing and migrating population as the EC cells are. The basal localization has been considered to result from a slower turnover- and migration rate of the endocrine lineage as compared to other cell types $(22,25)$.

The data from our experiments offer an altemative explanation for the specific mucosal distribution of enteroendocrine cells. During continuous labeling, the $\mathrm{LI}$ in the lower crypt half always exceeds the LI in the upper crypt region (Fig. 2b). This implies that endocrine cells are lost during the process of migration 
along the crypt. Moreover, for labeling periods of 16 days or longer, one can simply calculate that the absolute difference in labeled EC cells between upper and lower crypt halves more or less accounts for the overall difference in EC cells. whereas the unlabeled $\mathrm{EC}$ cells at these timepoints are roughly equally distributed over upper and lower parts of the crypts. This implies that the loss of endocrine cells mainly takes place in the relatively rapidly renewing population and that the fairly slowly renewing fraction is evenly distributed over the crypts, indicating that the EC cells with shorter turnover time represent the major portion of migrating cells, whereas their slower renewing counterparts represent a more static, resident population. Further search for morphologic, functional or ontogenetic differences between these two kinetically distinct subpopulations of EC cells is mandatory.

The loss of endocrine cells during migration, resulting in their characteristic basal localization, can have various reasons. It could simply be accounted for by extrusion of a part of the endocrine population into the crypt lumen before reaching the mucosal surface. This is unlikely, for it has been demonstrated that endocrine cells share the fate of the other cell lineages, which is cell death and desquamation from the villus tip in the small intestine or between crypt mouths in the large bowel (26-28).

We would favor an alternative explanation, namely that endocrine cells disappear by differentiating into one of the other cell types. In this way, a fair portion of the endocrine population would serve as precursor cells for the apparently more differentiated goblet- and columnar cells. In this concept, the endocrine phenotype would partly represent a transient phase during normal growth and differentiation in intestinal epithelium. The existence of "amphicrine" cells, containing both mucin and neurosecretory granules, in normal and neoplastic intestinal epithelium (29), supports transitions berween the various cell lineages. In conclusion, EC cells in the rat caecum are renewed by combination of self-replication and recruitment from primitive precursor cells. They are subject to migration towards the mucosal surface. There appear to be two kinetically distinct subpopulations, a relatively rapidly renewing fraction (60-65\%) with a turnover time of approximately 16 days and a relatively slowly renewing fraction (35-40\%) renewed in about 150 days.

The preferential basal localization in the intestinal crypts results from loss of immunohistochemically identifiable EC cells during migration. 


\subsection{REFERENCES}

1. Lewin KJ. The endocrine cells of the gastrointestinal tract. Part 1. The nomal endocrine cells and their hyperplasias. Pathol Annu 1986;21 Part 1:1-27.

2. Solcia E, Capella C, Buffa R, Usellini L, Fiocca R, Sessa F. Endocrine cells of the digestive system. In: Physiology of the Gastrointestinal Tract. Johnson LR ed, Raven Press, New York, 1987, pp.111-130.

3. Solcia E, Usellini L, Buffa R, Rindi G, Villani L, Zampatti C, Silini E. Endocrine cells producing regulatory peptides. Experientia 1987;43:839-850.

4. Dayal Y, De Lellis RA, Wolfe HJ. Hyperplastic lesions of the gastrointestinal endocrine cells. Amer J Surg Pathol 1987;11(Supp.I):87-101.

5. Shah KK, De Ridder PH, Shah KK. Ectopic gastric mucosa in proximal esophagus. Its clinical significance and hormonal profile. J Clin Gastroenterol 1986;8:509-513.

6. Bosman FT, De Bruine A. Endocrine cells in nonendocrine tumors of the gut and pancreas. In: Endocrine Pathology of the Gut and Pancreas. Dayal Y ed, CRC Press, Boca Raton, Florida, 1991, pp.319-338.

7. Pietroletti R, Blaauwgeers ЛG, Taat CW, Simi M, Brummelkamp WH, Becker AE. Intestinal endocrine cells in radiation enteritis. Surg Gynecol Obstet 1989;169:127-130.

8. Phillips SF. Functions of the large bowel: an overview. Scand J Gastroenterol 1984;19(Supp. 93):1-11.

9. Inokuchi H, Fujimoto S, Kawai K. Cellular kinetics of gastrointestinal mucosa, with special reference to gut endocrine cells. Arch Histol Jap 1983;46:137-157.

10. Ormsbee III HS, Fondacaro JD. Action of serotonin on the gastrointestinal tract. Proc Soc Exp Biol Med 1985;178:333-338.

11. Sjölund K, Sandén G, Håkanson R, Sundler F. Endocrine cells in human intestine: an immunocytochemical study. Gastroenterology 1983;85:1120-1130.

12. Gratzner HG. Monoclonal antibody to 5-bromo- and 5-iododeox yuridine: a new reagent. for detection of DNA replication. Science 1982;218:474-475.

13. Schutte B, Reynders MMJ, Bosman FT, Blijham GH. Studies with anti-bromodeoxyuridine antibodies: II Simultaneous immunocytochemical detection of antigen expression and DNA synthesis by in vivo labeling of mouse intestinal mucosa. I Histochem Cytochem 1987;35:371-374.

14. Verhofstad AAJ, Steinbusch HWM, Joosten HWJ, Penke B, Varga J, Goldstein M. Immunocytochemical localization of noradrenaline, adrenaline and serotonin. In; Immunocytochemistry. Practical Applications in Pathology and Biology. Polak JM, Van Noorden S eds, Wright, PSG, Bristol, UK, 1983, pp.143-168.

15. Guy-Grand D, Dy M, Luffau G, Vassalli P. Gut mucosal mast cells. Origin, traffic and differentiation. J Exp Med 1984;160:12-28.

16. Enerbäck L, Wingren U. Histamine content of peritoneal and tissue mast cells of growing rats. Histochemistry 1980;66:113-124.

17. Grimelius L. A silver nitrate stain for $\alpha 2$-cells in human pancreatic islets. Acta Soc Med Upsal 1968;73:243-270.

18. Inokuchi H, Kawai K, Takeuchi Y, Sano Y. Immunohistochemical demonstration of EC cells in rat gastrointestinal tract. Histochemistry 1982;74:453-456.

19. Kubben FJGM, Bosman FT. Proliferative activity of gastric and duodenal endocrine cells in the rat. Histochemistry 1989;92:325-329. 
20. Deschner EE, Lipkin M. An autoradiographic study of the renewal of argentaffin cells in human rectal mucosa. Exp Cell Res 1966;43:661-665.

21. Tielemans Y, Håkanson R, Sundler F, Willems G. Proliferation of enterochromaffinlike cells in Omeprazole-treated hypergastrinemic rats. Gastroenterology 1989;96:723-729.

22. Chang WWL, Leblond CP. Renewal of the epithelium in the descending colon of the mouse. II Renewal of argentaffin cells. Am J Anatomy 1971;131:101-110.

23. Hattori T, Fujita S. Tritiated thymidine autoradiographic study of cell migration and renewal in the pyloric mucosa of golden hamsters. Cell Tissue Res 1976;175:49-57.

24. Lipkin M. Proliferation and differentiation of normal and diseased gastrointestinal cells. In: Physiology of the Gastrointestinal Tract. Johnson LR ed, Raven Press, New York, 1987, pp.255-284.

25. Cheng $H$, Leblond $C P$. Origin, differentiation and renewal of the four main epithelial cell types in the mouse small intestine. III Entero-endocrine cells. Am J Anatomy 1974; 141:503-520.

26. Josephson RL, Altmann GG. Distribution of diazo-positive (argentaffin) cells in the small intestine of rats of various ages. Am J Anatomy 1973;136:15-22.

27. Linss W. Electron microscopic observations on the extrusion of enteroendocrine cells from the epithelium of the mouse small intestine. Anat Anz Jena 1984;155:173-181.

28. Baron DA, Miller DB. Extrusion of colonic epithelial cells in vitro. J Electron Microsc Tech 1990; 16:15-24.

29. Chejfec G, Capella C, Solcia E, Jao W, Gould VE. Amphicrine cells, dysplasias and neoplasias. Cancer 1985;56:2683-2690. 


\section{CHAPTER 3}

NCI-H716 CELLS AS A MODEL FOR ENDOCRINE

DIFFERENTIATION IN

COLORECTAL CANCER

A.P. de Bruine, W.N.M. Dinjens, M.M.J. Pijls, E.P.M. v.d. Linden, M.J.M. Rousch, P.T. Moerkerk, A.F.P.M. de Goeij, and F.T. Bosman. 


\subsection{INTRODUCTION}

Normal colonic epithelium contains resorptive columnar cells, mucin producing goblet cells and endocrine cells, which probably all originate from a common endodermal stem cell located in the mucosal crypt base (1-6).

In gastrointestinal cancer, endocrine differentiation occurs relatively often (7). The biological and clinical significance of endocrine differentiation in gastrointestinal neoplasia has not yet clearly been elucidated, although there have been reports in the literature suggesting a poorer prognosis for tumors with endocrine components as compared to non-endocrine tumors $(8,9)$. In this respect, small cell undifferentiated carcinomas or stem cell carcinomas $(10,11)$, consisting of primitive cells with endocrine features, form the most salient example of immature, highly aggressive endocrine tumors. This behavior might be explained through growth regulatory effects of polypeptides and amines which might influence tumorgrowth by para- or autocrine mechanisms $(12,13)$. Alternatively, endocrine cells might reflect the presence of a more immature and therefore more aggressive tumor stem cell (14).

In vitro models might be used to study the factors which regulate endocrine differentiation, the position of endocrine cells in the spectrum of intestinal epithelial differentiation and the role of neurohormonal peptides in growth regulation of colon cancer. Unfortunately, contrasting with the relatively high prevalence of endocrine differentiation in colorectal tumors, most cell lines derived from these tumors merely display columnar- and goblet cell characteristics. Only sporadically a colon cancer cell line has been obtained with endocrine differentiation, which exclusively occurred in vivo (15).

We studied growth and differentiation in the NCI-H716 cell line, which was originally derived from a poorly differentiated adenocarcinoma of the caecum (16). The cells were studied in vitro and in vivo as tumor xenografts in athymic mice. DNA flowcytometry, karyotyping, immunohistochemistry using a panel of differentiation related antibodies, Northem blot analysis and electronmicroscopy, were used to characterize the tumor cells. Receptors for biogenic amines and peptide hormones were quantitated by ligand binding assay.

\subsection{MATERIALS AND METHODS}

\subsubsection{NCI-H716 cells}

NCI-H716 cells, originally developed from a poorly differentiated caecal adenocarcinoma, were obtained from the American Type Culture Collection (ATCC, Rockville, Maryland, USA). 


\subsubsection{Cell culture}

Cells were cultured at $37^{\circ} \mathrm{C}$ in an atmosphere of air with $5 \% \mathrm{CO} 2$. The medium consisted of Dulbecco's modified Eagles' minimal essential medium (DMEM, Flow Laboratories), either serumfree, supplemented with $10 \%$ fetal bovine serum (FBS, Boehringer) or with $10 \%$ dialyzed FBS. Penicillin (100 IU/ml), streptomycin $(100 \mu \mathrm{g} / \mathrm{ml})$ and amphotericin B $(2.5 \mu \mathrm{g} / \mathrm{ml})$ were added. The culture medium was modified by addition of the differentiation inducing agents sodiumbutyrate (NaBT, $2 \mathrm{mM}$ ), dimethylsulfoxide (DMSO, 2\% v/v), dimethylformamide (DMF, $1 \% \mathrm{v} / \mathrm{v})$, retinoic acid $(\mathrm{RA}, 35 \mu \mathrm{M})$ or phorbolmyristate acetate $(\mathrm{PMA}, 10 \mathrm{ng} / \mathrm{ml})$. Culture vials were either uncoated or coated with soluble extracted type I, III and IV collagen, fibronectin and laminin (all 100 $\mu \mathrm{g} / \mathrm{ml})$.

\subsubsection{Xenografts}

In vivo growth was investigated by injection of $3-5 \times 10^{6}$ single tumor cells in phosphate buffered saline (PBS) at various sites in female CD nu/nu mice aged 3-5 weeks (Charles River Wiga, Sulzfeld, Germany).

\subsubsection{Cell and Tissue Processing}

Cells growing in suspension were collected by aspiration; attached cells were gently removed with a rubber cell scraper. After washing twice in icecold PBS, cells were fixed in a mixture of ethanol $100 \%$, formalin $36 \%$ and acetic acid $97 \%$ $(15: 4: 1 \mathrm{v} / \mathrm{v})$, or in ethanol $70 \%$. Cells were resuspended in $4 \%$ agarose gel, prior to routine processing and paraffin embedding. Xenografts removed from nude mice were fixed and processed similarly.

\subsubsection{Immunocytochemistry}

Paraffin sections $(4 \mu \mathrm{m})$ were stained with haematoxylin \& eosin, Grimelius, and periodic acid-Schiff with and without diastase pretreatment. For immunocytochemistry, an indirect peroxidase labeled antibody technique was applied (17), using a panel of markers identifying the four cell lineages in intestinal epithelium (Table 1). As a positive control normal intestinal mucosa was chosen. As negative controls primary polyclonal antibodies were replaced by normal rabbit serum; primary monoclonal antibodies were omitted or replaced by normal mouse serum. Negative controls were consistently negative.

\subsubsection{Northern Blot Analysis}

The expression of the chromogranin A gene in NCI-H716 cells grown in vitro and in vivo was compared by Northern blot analysis of mRNA. RNA was extracted (overnight, $0^{\circ} \mathrm{C}$ ) from a subcutaneous (s.c.) xenograft tissue homogenate with $3 \mathrm{M} \mathrm{LiCl} / 6 \mathrm{M}$ ureum. After centrifugation (10000 rpm), RNA was purified with a mixture of phenol, chloroform and isoamylalcohol $(25: 24: 1 \mathrm{v} / \mathrm{v})$ 
TABLE 1. Applied Antibodies (nature, source, type and dilution)

$\begin{array}{lll}\begin{array}{ll}\text { 1. Intestinal Differentiation Markers } \\ \text { Paneth Cells }\end{array} & \text { Lysozyme } & \\ \text { Columnar Cells } & \text { Villin } & \text { DAKO-pc-1:2500 } \\ & \text { Secretory Component } & \text { DAKO-pc-1:1000 } \\ \text { Goblet Cells } & \text { Mucin (Parlam 3/9a) } & \text { own lab-mc-1:1000/2000 } \\ \text { Endocrine Cells } & \text { Chromogranin A } & \text { Hybritech-mc-1:12500 } \\ & \text { Synaptophysin } & \text { Progen-mc-1:500 } \\ \text { General Marker } & \text { CEA (Parlam 4 }{ }^{\text {b }} & \text { own lab-mc-1:1000 }\end{array}$

II. 2nd Antibodies

Swine-anti-rabbit peroxidase DAKO-1:150

Rabbit-anti-mouse peroxidase DAKO-1:200

${ }^{a}$ Ref. 35 ; ${ }^{b}$ Ref. 36

and precipitated with $96 \%$ ethanol. Lysis of tumor cells cultured in standard conditions was performed with $0.65 \% \mathrm{NP} 40,10 \mathrm{mM}$ vanadyl-ribonucleosidecomplex (GIBCO/BRL) in $10 \mathrm{mM}$ Tris (pH 7.8), $0.15 \mathrm{M} \mathrm{NaCl}$. After centrifugation, $1 \%$ SDS and $10 \mathrm{mM}$ EDTA were added to the supernatant and RNA was extracted and precipitated as described. RNA was size-fractionated by overnight electroforesis at $1.5 \mathrm{~V} / \mathrm{cm}$ in $1 \%$ agarose $/ 6 \%$ formaldehyde gel in MOPS buffer (20 mM 3-morphiline propanesulfonic acid, $5 \mathrm{mM}$ sodiumacetate, $1 \mathrm{mM}$ EDTA) and transferred to Hybond-N+ filters. Chromogranin A mRNA was detected with a $1.8 \mathrm{~kb}$ cDNA probe (clone $\mathrm{pHCGA}-4, \mathrm{ATCC}$ ). As positive control RNA from a human pheochromocytoma was hybridized; RNA from cultured HT-29 colon carcinoma cells was used as a negative control. Parallel hybridization for $B$ actin mRNA was performed as an internal standard for the total amount of RNA, with a $1.3 \mathrm{~kb}$ cDNA probe (courtesy of Dr. T. Berkvens, University of Leiden).

The Northern blots were prehybridized overnight at $42^{\circ} \mathrm{C}$ in $50 \%$ formamide, $1 \mathrm{M} \mathrm{NaCl}, 1 \%$ SDS, $10 \%$ dextran sulphate and $0.1 \mathrm{mg} / \mathrm{ml}$ denatured salmon sperm DNA. For hybridization, denatured chromogranin $A$ and $\beta$ actin probes radiolabeled with ${ }^{32} \mathrm{P}$ by the random primer method $(18,19)$ were added. After overnight incubation, the filters were washed in $2 \times S S C\left(2 \times 15^{\prime}, \mathrm{RT}\right), 2 \times S S C$ and $1 \%$ SDS $\left(2 \times 15^{\prime}, 60^{\circ} \mathrm{C}\right)$. The filters were exposed to Kodak-XAR film, at $-70^{\circ} \mathrm{C}$ with an Ilford intensifying screen. Autoradiograms were scanned by laser densitometry (Ultrascan 2202, LKB, Sweden). The relative amount of chromogranin A mRNA was calculated as the ratio of the densitometrically measured hybridization signals of chromogranin $A$ and $\beta$ actin. 


\subsubsection{Electron Microscopy}

For electron microscopy, cells or tissues were fixed for 2 hours in $2.5 \%$ buffered glutaraldehyde, postfixed during 1 hour in $1.0 \%$ osmiumtetroxide (both in 0.1 M phosphate buffer), dehydrated in graded ethanol series and embedded in Epon. Ultrathin sections were stained with uranyl acetate and lead citrate.

\subsubsection{DNA Flowcytometry}

Cells were harvested and fixed in ethanol $70 \%$. Nuclei were isolated in $0.25 \%$ trypsin in Tris-citrate buffer ( $\mathrm{pH} 7.6$ ), stained with propidium iodide and analyzed on a FACS IV flow cytometer (Beckton \& Dickinson, Sunnyvale, CA, USA). As an internal standard, parallel DNA analysis of chicken and trout red blood cells was performed.

\subsubsection{Cytogenetics}

Karyotyping of cells growing in suspension was performed on spontaneously occurring metaphases. Cells were exposed to $0.075 \mathrm{M} \mathrm{KCl}$ and fixed in three changes of methanol/glacial acetic acid $(3: 1 \mathrm{v} / \mathrm{v})$. Chromosomes were stained by a Giemsa-trypsin-G-banding procedure.

\subsubsection{Receptor Assay}

Receptors for gastrin, serotonin and somatostatin were determined by radioligand binding assay. For this purpose, gastrin (Sigma, St. Louis, USA) was labeled with ${ }^{125}$ I carrier free NaI (specific activity (s.a.) $2000 \mathrm{Ci} / \mathrm{mmol}$ ) by the Iodo-Gen method (Pierce Chemical Company, Rockford, Ill., USA)(labeling efficiency 25-30\%) (20). Serotonin receptors were quantitated with tritiated 5 -hydroxytryptamine creatinine sulphate $\left({ }^{3} \mathrm{H}-5-\mathrm{HT}\right.$, s.a. $\left.12.3 \mathrm{Ci} / \mathrm{mmol}\right)$. Somatostatin binding sites were assayed with ${ }^{125} \mathrm{I}$ lodo-Gen labeled somatostatin-14, substituted at position 1 with a tyrosine residue. Isotopes were purchased from Amersham International, UK.

Briefly, $10^{6}$ tumor cells in $200 \mu \mathrm{l}$ PBS were incubated for 2 hours at room temperature with an equal volume of receptor stabilizing buffer $(25 \mathrm{mM}$ HEPES, $2.5 \mathrm{mM} \mathrm{MgCl}_{2}, 5 \mathrm{mM} \mathrm{KCl}, 137 \mathrm{mM} \mathrm{NaCl}, 0.7 \mathrm{mM} \mathrm{NaHPO}, 10 \mathrm{mM}$ glucose, $\mathrm{pH}$ 7.4) containing $10 \mathrm{nM}$ radiolabeled ligand with or without a 1000 -fold excess of unlabeled ligand. After washing $4 \mathrm{x}$ in this buffer, radioactivity was determined with a $\gamma$ or $\beta$ counter. The receptor content was calculated from the amount of specifically bound radioligand, and expressed as, the number of binding sites per cell. Multi-point assays were performed for Scatchard plot analysis, to determine the maximum number of binding sites and the dissociation constant $\left(\mathrm{K}_{\mathrm{d}}\right)$ of the three ligands. 


\section{$3.3 \quad$ RESULTS}

\subsubsection{Genotyping}

By DNA flowcytometry and karyotyping NCl-H716 cells were aneuploid (Fig. la), which was supported by karyotyping. The modal chromosome number was 55 chromosomes with up to 14 marker chromosomes (Fig. 1b). All investigated cells contained numerous double minute chromosomes. These findings closely agree with the original description of the cell line (16).

\subsubsection{Cell Culture}

In vitro NCI-H716 cells grew in suspension as floating aggregates. Adherent growth was achieved by coating culture surfaces with type IV collagen, which resulted in cell-attachment and growth in sheets and three-dimensional cell clusters (Fig. 2). Coating with type I or type III collagen, laminin or fibronectin did not result in adherence.

\subsubsection{Xenografts}

Tumors developed in nude mice at several sites after latency periods of between 5 (s.c.) and 16 weeks (caecum). The highest take rate was achieved by inoculating the cells subcutaneously (Table 2). Histologically, the tumors showed a solid growth pattern with marked cytonuclear atypia, high mitotic activity and moderate necrosis. Invasive growth in surrounding structures was observed in both subcutaneous tumors and in the caecum (Fig. 3). Distant metastases were not found.

\subsubsection{Phenotyping}

Histochemically, mucin production was detected in a moderate number of cells, both in vivo and in vitro (Fig. 4). Endocrine differentiation, as reflected in argyrophilia or chromogranin A and synaptophysin immunoreactivity, was observed in less than $1 \%$ of the cells in vitro (in suspension and on type IV collagen), but in more than $50 \%$ of the cells in xenografts (Colorplate 2, page 84 ). Neither addition of various differentiation inducing agents (21), nor culturing in serumfree conditions or with dialyzed serum enhanced endocrine differentiation. Staining sections serially for mucins and chromogranin A showed cells which expressed both antigens (Colorplate 2). This was confirmed by electron microscopy: mucin vacuoles and neurosecretory granules $(\varnothing 200 \mathrm{~nm})$ were found in separate cells but also together in the cytoplasm (Fig. 5). Stains for Paneth cells (lysozyme), columnar cells (villin, SC) and CEA (Parlam 4) were consistently negative. 
a

Coll line H716 + CRBC + TRBC

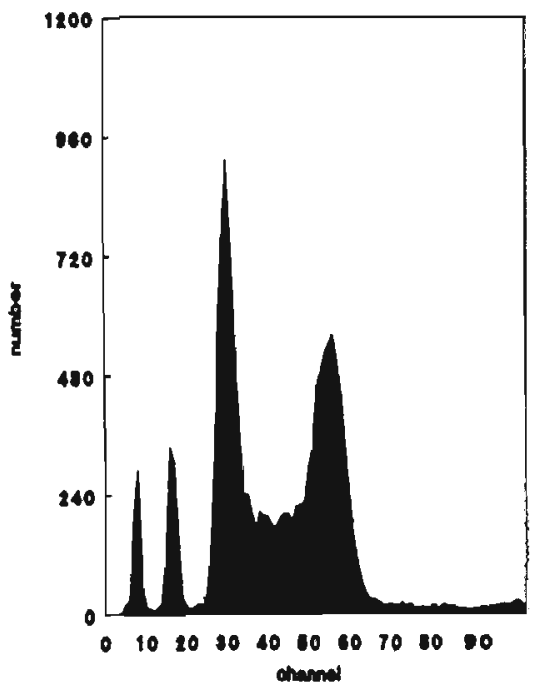

Figure 1. Cytogenetic characteristics of NCI-H716 cells. a. DNA histogram. $X$-axis: relative amount of DNA. Y-axis: cell number. On the basis of the two smaller reference peaks of chick and trout red blood cells, the diploid DNA content can be expected near channel no.20. Therefore the G1 peak (channel no.30) of NCI-H716 tumor cells represents a DNA index of about 1.5 . Karyotype of NCI-H716, showing 55 chromosomes and 14 marker chromosomes.

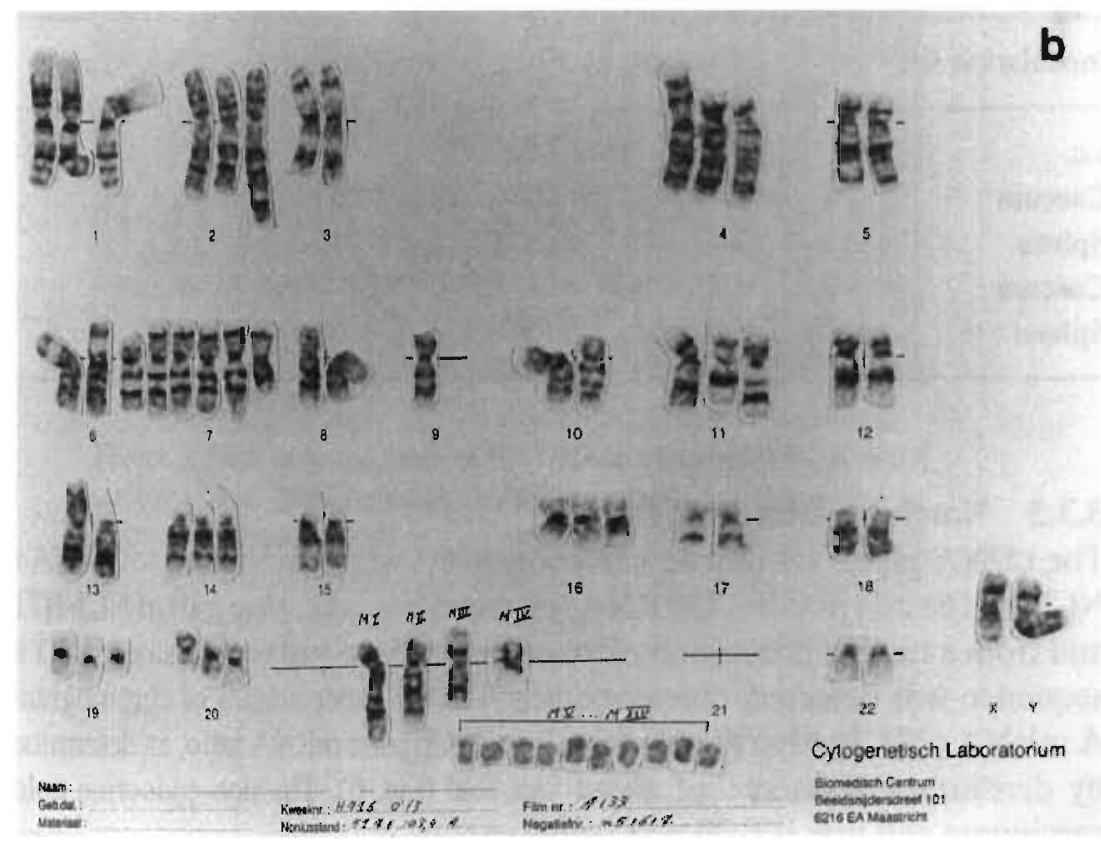




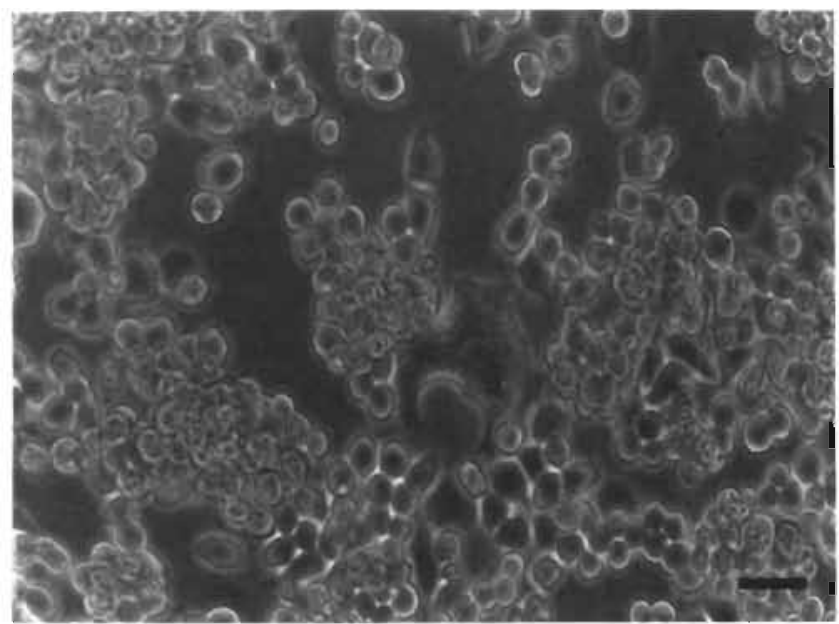

Figure 2. Phase-contrast micrograph of NCl-H716 cells in vitro. The cells which normally grow in suspension, can adhere to substrate coated with $100 \mu \mathrm{g} / \mathrm{ml}$ soluble extracted type IV collagen $(\mathrm{bar}=30 \mu \mathrm{m})$.

TABLE 2. Xenografting (Female CD nu/nu mice. $3-5$ weeks old, 3-5x $10^{6}$ cells/site)

\begin{tabular}{llll}
\hline Inoculation site & Time (wks.) & No. of animals & No. of tumors \\
\hline s.c. & $5-8$ & 6 & 6 \\
Caecum & 8 & 4 & 0 \\
Spleen & 8 & 4 & 0 \\
Caecum & 16 & 2 & 1 \\
Spleen & 16 & 2 & 0 \\
\hline
\end{tabular}

\subsubsection{Northern Blot Analysis}

The cDNA probe for human chromogranin A weakly hybridized with RNA of NCI-H7 16 cells in vitro. On RNA, extracted from a s.c. xenograft of NCI-H716 and from a human pheochromocytoma, an intense signal was obtained: a $2.1 \mathrm{~kb}$ sequence was detected, corresponding with the expected size of chromogranin A mRNA (22). In vivo the chromogranin $A / \beta$ actin mRNA ratio, as determined by densitometry, increased about ten-fold (Fig. 6). The non-endocrine colon carcinoma cell line HT-29 was negative. 

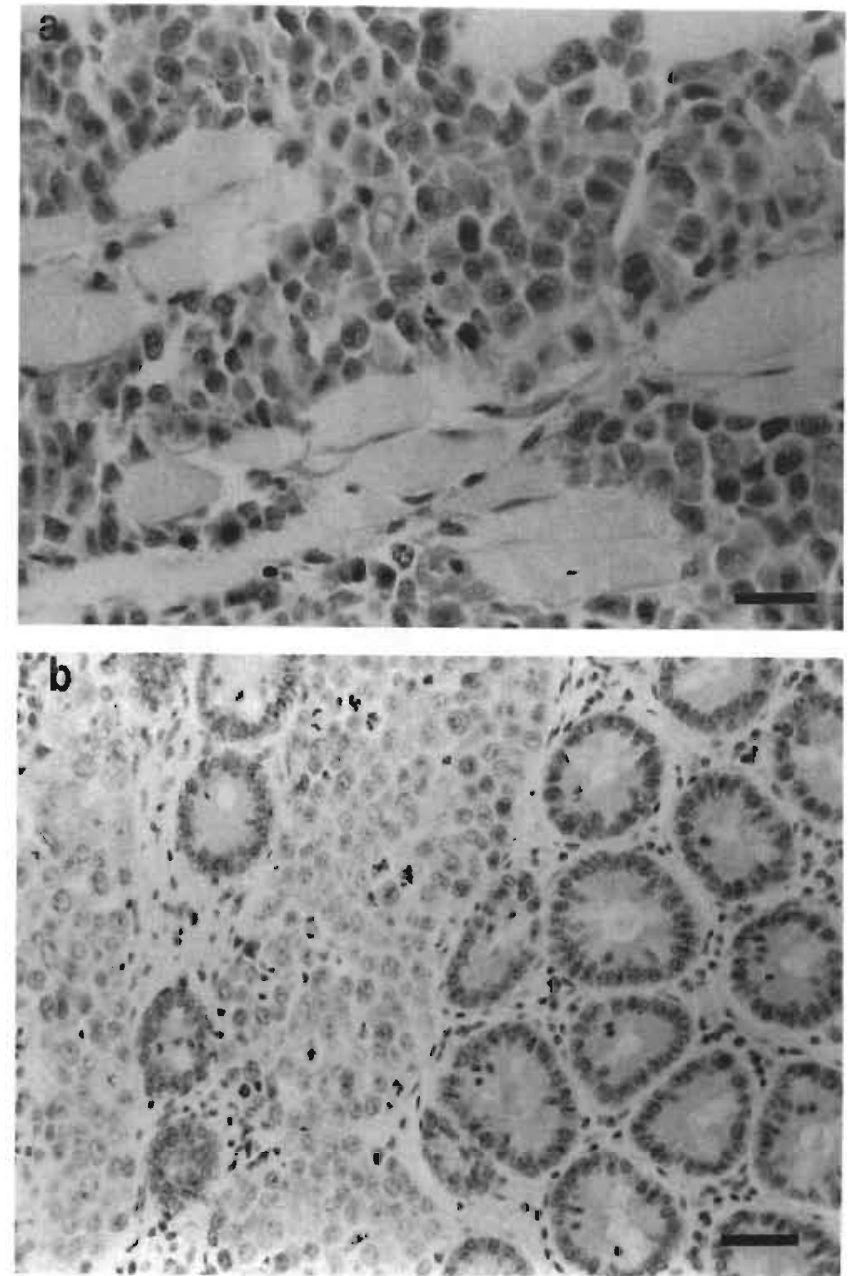

Figure 3. Nude mice xenogratts of NCI-H716. The cells form solid turnors without gland formation. Invasive growth can be noted in surrounding striated muscle in a subcutaneous tumor (a) and in the mucosal lamina propria in a caecal intramural xenograft (b) (H\&E, bar $=30 \mu \mathrm{m}(\mathrm{a})$ and $60 \mu \mathrm{m}(\mathrm{b}))$. 

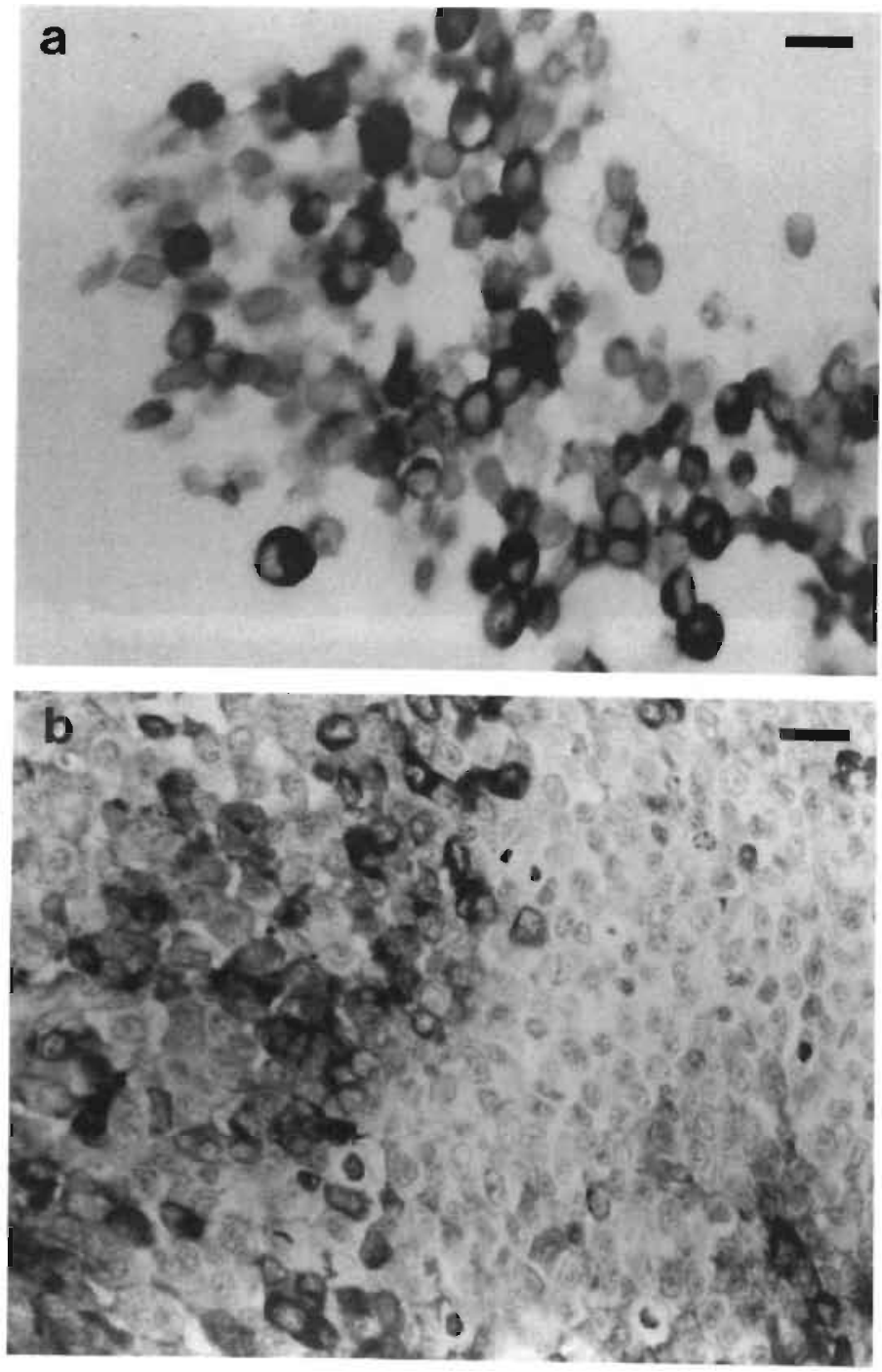

Figure 4. Mucin production in $\mathrm{NCl}-\mathrm{H} 716$ cells in vitro (a) and in vivo (b). Cells show strong cytoplasmic staining with a mixture of Parlam 3 and 9 monoclonal antibodies, detecting a $87 \mathrm{kD}$ protein moiety of goblet cell mucin glycoproteins in intestinal and colonic mucosa (Verstijnen et al. 1989) (indirect immunoperoxidase with DAB, bar $=30 \mu \mathrm{m}$ ). 

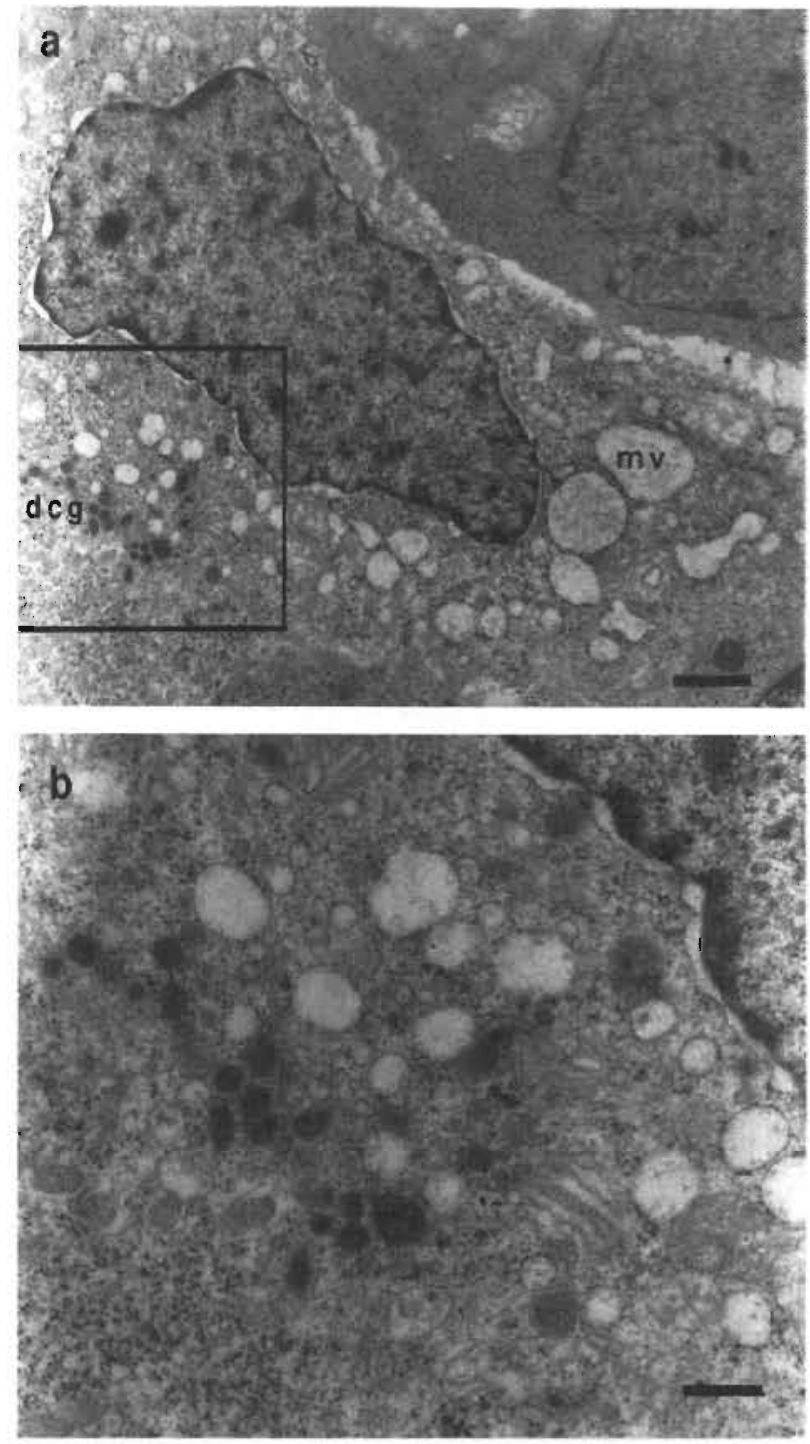

Figure 5. Transmission electron microscopy of an amphicrine NCI-H716 cell, containing both mucin vacuoles (mv) and densecore secretory granules $(\mathrm{dcg})$. a. Overview $(\mathrm{bar}=1.2 \mu \mathrm{m})$ b. Detail of inset in a. (bar $=340 \mathrm{~nm})$. 

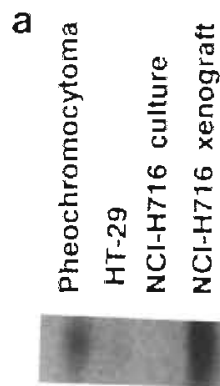

\title{
Chromogranin A
}

\author{
B Actin
}

b

$\mathrm{NCl}-\mathrm{H716}$

NORTHERN BLOT ANUYSIS

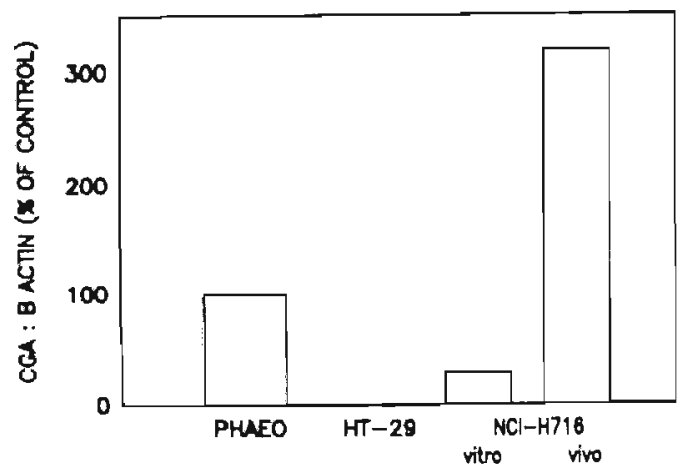

Figure 6. Comparison of chromogranin A mRNA expression in NCI-H7 16 cells growing in vitro under standard conditions and in a subcutaneous xenograft. a. Northem blots hybridized with ${ }^{32} \mathrm{P}$ labeled CDNA probes for chromogranin $A$ and $\beta$ actin. A human pheochromocytoma was used as a positive control; HT-29 colon carcinoma cells as a negative control. Hybridization for $\beta$ actin was performed as an internal standard for the amount of RNA. b. Densitometric quantification of the amount of chromogranin A mRNA (CGA), corrected for the amount of $\beta$ actin mRNA. The CGA/ $\beta$ actin mRNA ratio is given as percentage of the control (pheochromocytoma $100 \%$, HT-29 0\%). The amount of mRNA for chromogranin A in NCI-H716 cells shows an approximate 10-fold increase in vivo vs. in vitro. 


\section{Scatchard plot $\mathrm{NCl}-\mathrm{H} 716$ \\ Somatostatin receptor determination}

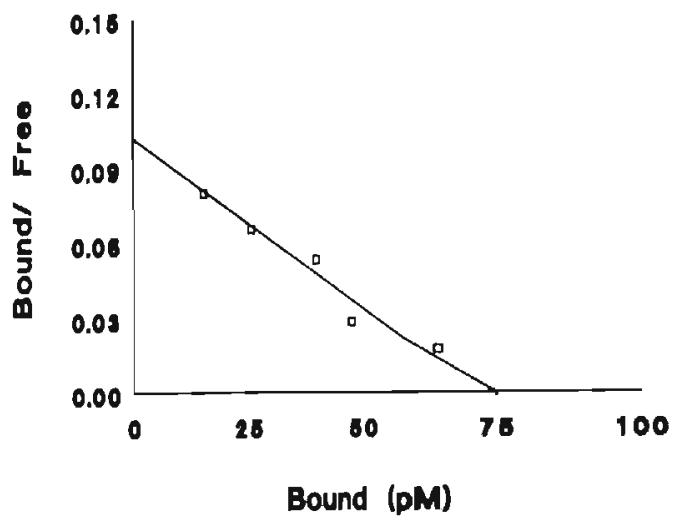

Figure 7. Representative Scatchard plot analysis for binding of ${ }^{125}$ I-Tyr 1 -Somatostatin- 14 to NCI-H716 cells. In this experiment the $B \max$ was $1.8 \times 10^{4}$ binding sites/cell, with a $\mathrm{K}_{\mathrm{d}}$ of $0.73 \mathrm{nM}$.

\subsubsection{Neurohormonal Receptors}

$\mathrm{NCl}-\mathrm{H} 716$ cells contained considerable amounts of high affinity receptors for gastrin (mean: $5.2 \times 10^{3}$ binding sites/cell, $\mathrm{K}_{\mathrm{d}} 3.6 \mathrm{nM}$ ), serotonin (mean: $5.2 \times 10^{4}$ binding sites/cell, $\mathrm{K}_{\mathrm{d}} 4.9 \mathrm{nM}$ ) and somatostatin (mean: $2.2 \times 10^{4}$ binding sites/cell, $\left.\mathrm{K}_{d} 0.75 \mathrm{nM}\right)$ (Fig. 7).

\subsection{DISCUSSION}

In the colorectum a spectrum of tumors with endocrine differentiation occurs. Endocrine features are characteristic of relatively benign carcinoid tumors but also occur in poorly differentiated, aggressive small cell undifferentiated carcinomas (23). As an intermediate group, adenocarcinomas with endocrine tumor cells occur, which account for $\pm 30 \%$ of colorectal carcinomas (24).

The significance of endocrine differentiation in colorectal neoplasia has not been unambiguously established. Some reports indicate a poorer prognosis for this subset of tumors $(8,9)$. This might be explained by assuming that carcinomas with endocrine differentiation arise from a more immature and therefore more aggressive tumor stem cell. An alternative possibility might be autocrine growth stimulating effects of polypeptides and amines produced by the endocrine cell population. 
The tumor stem cell theory is based upon the biology of enteroendocrine cells in normal mucosa. In intestinal crypts, endocrine cells mainly occur in a basal position, adjoining the proposed location of intestinal stem cells $(25,26)$, which suggests that they are relatively immature. Also, the occurrence of multiple lines of differentiation in a carcinoma suggests pluripotentiality and therefore relative immaturity of the tumor stem cell.

That the growth of normal and neoplastic gastrointestinal epithelial cells is regulated by neurohormonal peptides and biogenic amines has been conclusively demonstrated in several reports (27-31). Both stimulatory (gastrin, serotonin) and inhibitory (somatostatin) effects have been claimed.

To definitively clarify the relevance of endocrine differentiation in colorectal cancer, combined clinical and basic research is needed, which requires well documented patient trials as well as defined tumor models. The latter depends on the availability of in vitro cell systems. However, contrasting with the relatively high prevalence of endocrine features in colorectal carcinomas in vivo, cell lines derived from colorectal carcinomas with endocrine differentiation are extremely rare. So far, the only established tumor cell line displaying endocrine characteristics is the HRA-19 cell line, which was derived from a rectal adenocarcinoma (15). This cell line can be induced to differentiate into columnar, goblet and endocrine direction. Endocrine cells in this cell line occur only in tumor xenografts in immunedeficient mice. and not in vitro. This finding indicates that (putatively stromal) host factors induce endocrine differentiation in vivo.

Our studies show that NCI-H716 cells display limited endocrine differentiation in vitro, which can be highly increased by xenografting the cells. Chromogranin A expression as a parameter for endocrine differentiation was detected both at the protein level by immunohistochemistry and at the mRNA level by Northern blot analysis, and demonstrated that enhanced endocrine differentiation is not merely a matter of increased peptide storage but also of increased gene expression. The possibility that rate limiting growth conditions in xenografts induce endocrine differentiation was ruled out by culturing the cells in proliferation restricting conditions (e.g. in medium with dialyzed serum or in serumfree medium). This led to reduced growth (data not shown) but not to augmented endocrine differentiation. We propose that interactions between tumor cells and stroma in vivo play an important role. This fits with the ability of NCI-H716 cells to adhere to extracted solubilized extracellular matrix components such as type IV collagen. However, the induction of endocrine differentiation must involve complex interactions, because individual extracellular matrix components did not induce endocrine differentiation.

NCI-H716 cells were found to produce mucin, more or less constantly, regardless of the growth conditions. Immunohistochemical and electron microscopical studies disclosed amphicrine cells, which combined exo- and endocrine differ- 
entiation as described previously (32-34). This finding lends credit to the theory of transitional differentiation from one intestinal epithelial cell type into another (14).

We found NCI-H716 cells to contain considerable amounts of high affinity binding sites for gastrin, somatostatin and serotonin. These neurohormonal substances have been implicated in regulation of gastrointestinal epithelial growth. Models enabling investigations of cellular growth modulation by gut peptides and biogenic amines are scarce. Therefore, NCI-H716 cells constitute a valuable tool for studies concerning the function of neurohormonal substances in modulation of colorectal cancer growth.

In summary, $\mathrm{NCl}-\mathrm{H} 716$ cells comprise undifferentiated, endocrine, mucin-producing and amphicrine cells, with plasma membrane receptors for gastrin, somatostatin and serotonin. Endocrine differentiation is increased in vivo, suggesting a role for stromal components in inducing the endocrine phenotype. 


\subsection{REFERENCES}

1. Chang WW, Leblond CP. A unitarian theory of the origin of the three populations of epithelial cells in the mouse large intestine. Anat Rec 1971;169:293.

2. Cheng $\mathrm{H}$, Leblond $\mathrm{CP}$. Origin, differentiation and renewal of the four main epithelial cell types in the mouse small intestine $\mathrm{V}$. Unitarian theory of the origin of the four epithelial cell types. Am J Anat 1974; 141:537-562.

3. Cox WF, Pierce GB. The endodermal origin of the endocrine cells of an adenocarcinoma of the colon of the rat. Cancer 1982;50:1530-1538.

4. Ponder BAJ, Schmidt GH, Wilkinson MM, Wood MJ, Monk M, Reid A. Derivation of mouse intestinal crypts from single progenitor cells. Nature 1985;313:689-691.

5. Kirkland SC. Clonal origin of columnar, mucous, and endocrine cell lineages in human colorectal epithelium. Cancer 1988;61:1359-1363.

6. Cohn SM, Roth KA, Birkenmeier EH, Gordon Л. Temporal and spatial patterns of transgene expression in aging adult mice provide insights about the origins, organization, and differentiation of the intestinal epithelium. Proc Nat Acad Sci USA 1991;88:1034-1038.

7. Bosman FT, De Bruïne A. Endocrine cells in non-endocrine tumors of the gut and pancreas. In: Dayal Y ed, Endocrine pathology of the gut and pancreas. CRC Press, Boca Raton Ann Arbor Boston, 1991, pp.319-338.

8. Arends JW, Wiggers T, Verstijnen C, Bosman FT. The occurrence and clinicopathological significance of serotonin immunoreactive cells in large bowel carcinoma. J Pathol 1986;149:97-102.

9. Jansson D, Gould VE, Gooch GT, Rittenhouse HG, Sik Shin S, Manderino GL, Tomita JT, Staren ED. Immunohistochemical analysis of colon carcinomas applying exocrine and neuroendocrine markers. APMIS 1988;96:1129-1139.

10. Redman BG, Pazdur R. Colonic small cell undifferentiated carcinoma: a distinct pathological diagnosis with therapeutic implications. Am J Gastroenterol 1987;82:382-385.

11. Palvio DHB, Sorensen FB, Klove-Mogensen M. Stem cell carcinoma of the colon and rectum. Dis Colon Rectum 1985;28:440-445.

12. Johnson LR. Regulation of gastrointestinal mucosal growth. Physiol Rev 1988;68:456502.

13. Hoosein NM, Kiener PA, Curry RC, Brattain MG. Evidence for autocrine growth stimulation of cultured colon tumor cells by a gastrin/cholecystokinin-like peptide. Exp Cell Res 1990;186:15-21.

14. De Bruïne AP, Dinjens WNM, Zijlema JHL, Lenders M-H, Bosman FT. Renewal of enterochromaffin cells in the rat caecum. Anat Rec 1992;233:75-82.

15. Kirkland SC. Endocrine differentiation by a human rectal adenocarcinoma cell line (HRA-19). Differentiation 1986;33:148-155.

16. Park J-G, Oie HK, Sugarbaker PH, Henslee JG, Chen T-R, Johnson BE, Gazdar A. Characteristics of cell lines established from human colorectal carcinoma. Cancer Res 1987;47:6710-6718.

17. Dinjens WN, Ten Kate J, Kirch JA, Tanke HJ, Van der Linden EP, Van den Ingh HF, Van Steenbrugge GJ, Meera Khan P, Bosman FT. Adenosine deaminase complexing protein (ADCP) expression and metastatic potential in prostatic adenocarcinomas. J Pathol 1990;160:195-201. 
18. Feinberg AP, Vogelstein B. "A technique for radiolabeling DNA restriction endonuclease fragments to high specific activity". Addendum. Anal Biochem 1984;137:266267.

19. Moerkerk PT, Kessels HJ, Ten Kate J, De Goeij AFPM, Bosman FT. Southern and dot blot analysis of DNA from formalin-fixed, paraffin-embedded tissue samples from colonic carcinomas. Virchows Arch B Cell Pathol 1990;58:351-355.

20. Singh P, Rae-Venter B, Townsend CM, Khalil T, Thompson JC. Gastrin receptors in nomal and malignant gastrointestinal mucosa: age-associated changes. Am J Physiol 1985;249:G76!-G769.

21. Tsao, D, Morita A, Bella A, Luu P, Kim YS. Differential eflects of sodium butyrate, dimethyl sulfoxide, and retinoic acid on membrane-associated antigen, enzymes and glycoproteins of human rectal adenocarcinoma cells. Cancer Res 1982;42:1052-1058.

22. Helman LJ, Ahn TG, Levine MA, Allison A, Cohen PS, Cooper MJ, Cohn DV, Isracl MA. Molecular cloning and primary structure of human chromogranin A (secretory protein I) cDNA. J Biol Chem 1988;263:11559-I 1563.

23. Bosman FT. Neuroendocrine cells in non-neuroendocrine tumours. In: Falkmer S, Håkanson R, Sundler F eds, Evolution and tumour pathology of the neuroendocrine system. Elsevier, Amsterdam New York Oxford, 1984, pp.519-543.

24. Ho SB, Itzkowitz SH, Friera AM, Jiang S-H, Kim YS. Cell lineage markers in premalignant and malignant colonic mucosa. Gastroenterology 1989:97:392-404.

25. Bjerknes $\mathrm{M}$, Cheng $\mathrm{H}$. The stem-cell zone of the small intestinal epithelium. III. Evidence from columnar, enteroendocrine, and mucous cells in the adult mouse. Am J Anat 1981;160:77-91.

26. Potten CS, Hendry JH, Moore JV. Estimates of the number of clonogenic cells in crypts of murine small intestine. Virchows Arch B Cell Path 1987;53:227-234.

27. Winsett OE, Townsend CM, Glass EJ, Thompson JC. Gastrin stimulates growth of colon cancer. Surgery 1986;99:302-307.

28. Johnson LR. Trophic effects of gastrin on the colon. In: Wolman SR, Mastromarino A eds, Progress in cancer research and therapy, Vol.29., Raven Press, New York, 1984. pp. 327-336.

29. Johnson LR, Regulation of gastrointestinal growth. In: Johnson LR ed, Physiology of the gastrointestinal tract, 2nd edition, Raven Press, New York, 1987, pp.301-333.

30. Singh P, Le S, Townsend CM, Beauchamp RD, Laridjani A, Thompson JC. A long acting somatostatin analog and proglumide inhibit the trophic and gastrin regulatory effects of pentagastrin on mouse colon cancer cells in vivo. Gastrocnterology 1986;90:1636.

31. Tutton PJM, Barkla DH. Biogenic amines as regulators of the proliferative activity of normal and neoplastic intestinal epithelial cells (review). Anticancer Res 1987;7:1-12.

32. Ratzenhofer M. Hyperplasias and tumors of the disseminated endocrine (paracrine) Helle Zellen Feyrter's of the gut with special regard of amphicrine cell proliferations. In: Verh Disch Ges Pathol, 61 Tagg Erlangen. Gustav Fischer, Stuttgart New York, 1977, pp.7-24.

33. Höfler H, Klöppel G, Heitz PU. Combined production of mucus, amines and peptides by goblet-cell carcinoids of the appendix and ileum. Pathol Res Pract 1984;178:555-561

34. Chejfec G, Capella C, Solcia E, Wellington JAO, Gould VE. Amphicrine cells, dysplasias, and neoplasias. Cancer 1985;56:2683-2690. 
35. V'erstijnen CPHJ, Arends JW, Moerkerk PTM, Pijls M, Kuypers-Engelen B, Bosman FT. Colonic epithelium reactive monoclonal antibodies - Identification and immunohistochemical localization of target epitopes. Histochemistry 1989;92:397-406.

36. Verstijnen CPHJ, Arends JW, Moerkerk PTM, Warnaar SO, Hilgers J, Bosman FT. CEA-specificity of CEA-reactive monoclonal antibodies. Immunochemical and immunocytochemical studies. Anticancer Res 1986;6:97-104. 


\section{CHAPTER 4}

\section{EXTRACELLULAR MATRIX COMPONENTS INDUCE ENDOCRINE DIFFERENTIATION IN VITRO IN NCI-H716 CELLS}

A.P. de Bruine, W.N.M. Dinjens, E.P.M. v.d. Linden, M.M.J. Pijls, P.T. Moerkerk, and F.T. Bosman. 


\subsection{INTRODUCTION}

Normal colonic epithelium contains columnar cells, goblet cells and endocrine cells (ECs), which are all considered to be the progeny of a common endodermal stem cell, presumed to reside in the mucosal crypt base (1-7). ECs in the intestines have been widely studied for their role in maintaining gut functions, through production and secretion of a wide array of polypeptide hormones and biogenic amines (8-10). Comparatively little is known on the role of ECs and their synthesis products in regulating intestinal growth (11) and on the position occupied by ECs in the spectrum of intestinal differentiation (12). The potential relevance of endocrine cells for the regulation of growth and differentiation in the normal epithelium also has a bearing on neoplasia. In the large intestine, endocrine differentiation in tumors covers a spectrum, ranging from highly differentiated, relatively indolent carcinoid tumors to poorly differentiated, extremely aggressive small cell undifferentiated carcinomas $(13,14)$, via a heterogeneous group of combined exo- and endocrine tumors, including adenocarcinomas, which in $\pm 30 \%$ of cases contain scattered endocrine tumor cells (15). Although tumors with endocrine differentiation might have a relatively poor prognosis (16-18), this matter has not been completely resolved. A more aggressive behavior could be related to a relatively low differentiation level of endocrine cells (19), or to secretion of growth regulating neurohormonal peptides by endocrine tumor cells (20).

To study the biological relevance of endocrine differentiation in adenocarcinomas, in vitro models are needed. However, endocrine characteristics in colorectal tumor cell lines are rare and have mainly been found in xenografts (21). This suggests a role for extracellular matrix in generating endocrine features. From embryological studies it is known that the development of intestinal endocrine cells depends on contact between epithelium and appropriate mesenchyme (22). Epithelial-stromal interactions conceivably may also be necessary for the induction of the endocrine phenotype in tumor cells. This hypothesis was studied in the NCI-H716 cell line, derived from ascitic fluid of a patient with a poorly differentiated caecal adenocarcinoma (23). In the original description of the cell line, endocrine differentiation was demonstrated by DOPA-decarboxylase activity and dense core secretory granules. Commonly occurring colorectal tumor markers such as CA 19-9, TAG-72 and CEA were absent. We recently further characterized this cell line, and in addition to endocrine characteristics, also identified mucin production and the presence of high affinity receptors for several neurohormones, which makes the cell line NCI-H716 a suitable mudel to study endocrine differentiation in colorectal adenocarcinomas (24). In the current study we compared endocrine differentiation in vivo and in vitro and attempted to identify the factors governing the expression of the endocrine phenotype in vitro. As parameter for endocrine 
differentiation, we studied expression of chromogranin A (CGA), a 75-85 kD soluble monomeric acidic protein present in neurosecretory granules of practically all neuroendocrine cell types, and currently the most sensitive marker for endocrine differentiation in normal and neoplastic tissue (25).

\subsection{Materials and Methods}

\subsubsection{Tumor cells}

NCI-H716 cells were obtained from the American Type Culture Collection (ATCC, Rockville, Maryland, USA).

\subsubsection{In vitro studies}

Cells were cultured in $25 \mathrm{~cm}$ flasks or 6 -well plates (Costar) at $37^{\circ} \mathrm{C}$ in an atmosphere of air with 5\% CO2. The culture medium consisted of Dulbecco's modified Eagles' minimal essential medium (DMEM, Flow Laboratories), either serumfree, with $10 \%$ fetal bovine serum (FBS, Boehringer) or $10 \%$ dialyzed FBS, supplemented with penicillin $(100 \mathrm{IU} / \mathrm{ml})$, streptomycin $(100$ $\mu \mathrm{g} / \mathrm{ml})$ and fungizone $(2.5 \mu \mathrm{g} / \mathrm{ml})$. Culturing conditions were modified by addition of the differentiation inducing agents sodiumbutyrate (NaBT, $2 \mathrm{mM}$ ), dimethylsulfoxide (DMSO, 2\% v/v), dimethylformamide (DMF, $1 \% \mathrm{v} / \mathrm{v}$ ), transretinoic acid $(\mathrm{RA}, 35 \mu \mathrm{M})$ or phorbolmyristate acetate (PMA, $10 \mathrm{ng} / \mathrm{ml}$ ). (DMSO was obtained from Merck, Darmstadt, Germany; al] other chemicals from Sigma, St. Louis, USA).

Furthermore, cells were cultured in fibroblast conditioned medium and in serumfree, defined medium (DMEM with hydrocortisone $50 \mathrm{nM}$, insulin 5 $\mu \mathrm{g} / \mathrm{ml}$, transferrin $5 \mu \mathrm{g} / \mathrm{ml}$, sodiumselenite $5 \mathrm{nM}$, ethanolamine $100 \mu \mathrm{M}$, putrescine $1 \mu \mathrm{M}$, spermidine $4 \mu \mathrm{M}$, spermine $4 \mu \mathrm{M}$ and $0.1 \%$ bovine serum albumin) in the presence or absence of basic fibroblast growth factor (bFGF, 10 $\mathrm{ng} / \mathrm{ml}$ ) and transforming growth factor $\beta$ (TGF $\beta, 1 \mathrm{ng} / \mathrm{ml}$ ).

The culturing substrate was modified by coating vials with soluble extracted extracellular matrix components (types I, III and IV collagen, fibronectin, laminin and heparan sulphate proteoglycan (HSPG), all $100 \mu \mathrm{g} / \mathrm{ml}$ ). Cell adhesion to type IV collagen was further analyzed by culturing cells in calcium and magnesium free medium, and by pretreating coated surfaces with a polyclonal rabbit anti-type IV collagen antibody (produced in our laboratory (26)) and with $110 \mathrm{mM}$ dithiotreitol (DTT) or $120 \mathrm{mM}$ iodoacetamide (Sigma, St. Louis, USA). In addition the cells were cultured on amnion membranes and on various mesenchymal substrates. Amnion membranes were stripped by washing in $1 \mathrm{M}$ sodiumchloride ( $\mathrm{NaCl}$ ), $2 \mathrm{mM} \mathrm{N}$-ethylmaleimide (NEM), $20 \mathrm{mM}$ ethylenediaminetetraacetic acid (EDTA) and 4\% deoxycholate and by scraping with a rubber policeman. Lamina propria was prepared from fragments of colon mu- 
cosa obtained from fresh colectomy specimens, by removal of the crypt epithelium with $1 \mathrm{mM}$ EDTA/1 $\mathrm{mM}$ EGTA/0.5 mM DTT in phosphate buffered saline (PBS) as described by Whitehead et al.(27). Several types of human fibroblasts were used as feeder layers for the tumor cells: adult fibroblasts, explanted from dermis of human skin obtained at autopsy, fetal fibroblasts, explanted from umbilical cord and embryonal fibroblasts, purchased from the ATCC. Fetal rat mesenchymal cells were isolated from the intestines of $16 \mathrm{~d}$. old Lewis rat fetuses (28). Also, tumor cells were grown on surfaces conditioned by confluent layers of fibroblasts, after removal of the fibroblasts with $25 \mathrm{mM}$ $\mathrm{NH} 4 \mathrm{OH}$.

Three-dimensional culturing was performed in two types of extracellular matrix gels. Vitrogen 100, a gel made from purified, pepsin-solubilized bovine dermal collagen, consisting of 95-98\% type I collagen and 2-5\% type III collagen, was purchased from the Collagen Corporation, Palo Alto, CA, USA.

Basement membrane Matrigel, a solubilized basement membrane preparation containing laminin, type IV collagen, heparan sulphate proteoglycans, entactin, nidogen and several growth factors (TGF $\beta$, FGF, TPA etc.), was purchased from Collaborative Research Incorporated, Bedford, Mass., USA.

\subsubsection{In vivo studies}

Immunedeficient female CD nu/nu mice (Charles River Wiga, Sulzfeld, Germany), aged 3-5 weeks, were inoculated in the dorsal subcutis $(n=6)$ or in the wall of the caecum $(n=6)$ with suspensions of $3-5 \times 10^{6}$ single tumor cells in phosphate buffered saline (PBS).

\subsubsection{Cell and tissue processing}

Cells growing in suspension were collected by aspiration; attached cells were removed by gentle cellscraping. After washing twice in icecold PBS, cells were immersed $\left(3 \mathrm{hrs} .4^{\circ} \mathrm{C}\right)$ in fixative containing ethanol $(100 \%)$, formalin $(36 \%)$ and glacial acetic acid $(97 \%)(15: 4: 1 \mathrm{v} / \mathrm{v})$. Cells were resuspended in $4 \%$ agarose gel prior to routine tissue processing and paraffin embedding. Xenografts removed from nude mice were fixed and processed similarly. For assay of cell surface receptor molecules, cytocentrifuge preparations of cultured tumor cells were prepared on poly-L-lysine coated slides and fixed in $1: 1(\mathrm{v} / \mathrm{v})$ methanol/acetone $\left(10 \mathrm{~min},-20^{\circ} \mathrm{C}\right)$.

\subsubsection{Immunocytochemistry}

Paraffin sections $(4 \mu \mathrm{m})$ were immunocytochemically stained, by a standard indirect immunoperoxidase technique as previously described (29). Endocrine differentiation was identified with a monoclonal antibody against human CGA (LK2H10 (30), Hybritech). The presence of cell adhesion molecules was de- 
TABLE 1. Applied Antibodies (Antigen, Clone, Source, Type and Dilution)

Specificity

I. Endocrine differentiation

-Chromogranin A

II. Intercellular Adhesion

-L-CAM

III. Integrin receptors

$-\alpha 2$ (VLA2)

$-\alpha 3$ (VLA3)

$-\alpha 6$ (VLA6)

$-\beta 3$

IV. Secondary Antibodies

-Rabbit-anti-mouse HRP

-Rabbit-anti-rat HRP
Antibody

LK2H I0 (Hybritech-mouse mc-1:12500)

6F9 (Eurodiagnostics-mouse mc-1:80)

Thromb/4-CLB ${ }^{1}$-mouse mc-1:10

I143-CLB-mouse mc-1:10

G0H3-CLB-rat mc- 1:10

C17-CLB-mouse mc-1:10

DAKO p 270-1:200

DAKO p 162-1:100

'Central Laboratory of the Netherlands Red Cross Blood Transfusion Service, Amsterdam.

tected with a panel of antibodies recognizing integrin receptor molecules and L-CAM (Table 1).

Paraffin embedded or frozen sections of normal colonic mucosa were chosen as appropriate positive controls. As negative controls primary monoclonal antibodies were omitted or replaced by normal mouse serum. Negative controls were consistently negative.

\subsubsection{Quantification and Statistical Analysis}

Immunohistochemical expression of $\mathrm{CGA}$ in $\mathrm{NCI}-\mathrm{H} 716$ cells grown in various culturing conditions was compared with control cells, grown in suspension or attached to type IV collagen. A readily apparent increase in the fraction of CGA immunoreactive cells was semiquantitatively scored, as indicated in Table 2 and illustrated in Figure 4. Experiments were performed at least in triplicate. The effect of bFGF on CGA immunoreactivity was compared with control cells, and evaluated by counting CGA immunoreactivity in $2 \times 10^{3}$ cells per experiment $(n=3)$. These data were statistically analyzed by $t$-test for independent groups with separate variances. 
TABLE 2. Effect of Substrate on Endocrine Differentiation

\begin{tabular}{lll}
\hline Substrate & Adhesion $^{1}$ & $\mathrm{CGA}^{2}$ \\
\hline Coll.IV & + & - \\
Coll.I/III & - & - \\
Laminin & - & - \\
Coll.IV/Laminin & + & - \\
Fibronectin & - & - \\
HSPG & - & - \\
Coll.IV/HSPG & + & ++ \\
Fibroblasts & + & + \\
Colon ECM & + & + \\
Amnion & + & $-1+$ \\
Vitrogen 100 & 0 & ++ \\
BM Matrigel & 0 & + \\
\hline
\end{tabular}

${ }^{1}$ Adhesion: - = no, $+=$ yes, $0=$ not applicable; ${ }^{2} \mathrm{CGA}:$ Immunohistochemical Chromogranin A expression; - = no increase compared to standard culture; $+=$ increased, $<50 \%$ of cells positive; $++=$ increased, $>50 \%$ of cells positive

\subsubsection{Northern Blot Analysis}

The expression of the chromogranin A gene in NCl-H716 cells grown in vitro and in vivo was compared by Northern blot analysis of mRNA. RNA was extracted (overnight, $0^{\circ} \mathrm{C}$ ) from a subcutaneous (s.c.) xenograft tissue homogenate with $3 \mathrm{M} \mathrm{LiCl} / 6 \mathrm{M}$ ureum. After centrifugation (10000 rpm), RNA was purified with a mixture of phenol, chloroform, and isoamylalcohol (25:24:1 v/v) and precipitated with $96 \%$ ethanol. Lysis of tumor cells cultured in standard conditions was performed with $0.65 \% \mathrm{NP} 40,10 \mathrm{mM}$ vanadyl-ribonucleosidecomplex (GIBCO/BRL) in $10 \mathrm{mM}$ Tris (pH 7.8), $0.15 \mathrm{M} \mathrm{NaCl}$. After centrifigation, $1 \%$ SDS and $10 \mathrm{mM}$ EDTA were added to the supernatant and RNA was extracted and precipitated as described. RNA was size-fractionated by overnight electrophoresis at $1.5 \mathrm{~V} / \mathrm{cm}$ in $1 \%$ agarose $/ 6 \%$ formaldehyde ge! in MOPS buffer (20 mM 3-morphiline propanesulfonic acid, $5 \mathrm{mM}$ sodiumacetate, $1 \mathrm{mM}$ EDTA) and transferred to Hybond-N+ filters. Chromogranin A mRNA was detected with a 1.8 kb cDNA probe (cione pHCG-A, A'TCC). As a positive contiol RNA from a human pheochiomocytoma was hybridized: RNA from cultured HT-29 colon carcinoma cells was used as a negative control. Parallel hybridization for $\beta$ actin mRNA was performed as an internal standard for the total amount of RNA, with a $1.3 \mathrm{~kb}$ cDNA probe (courtesy of Dr. T. Berkvens, University of Leiden). 

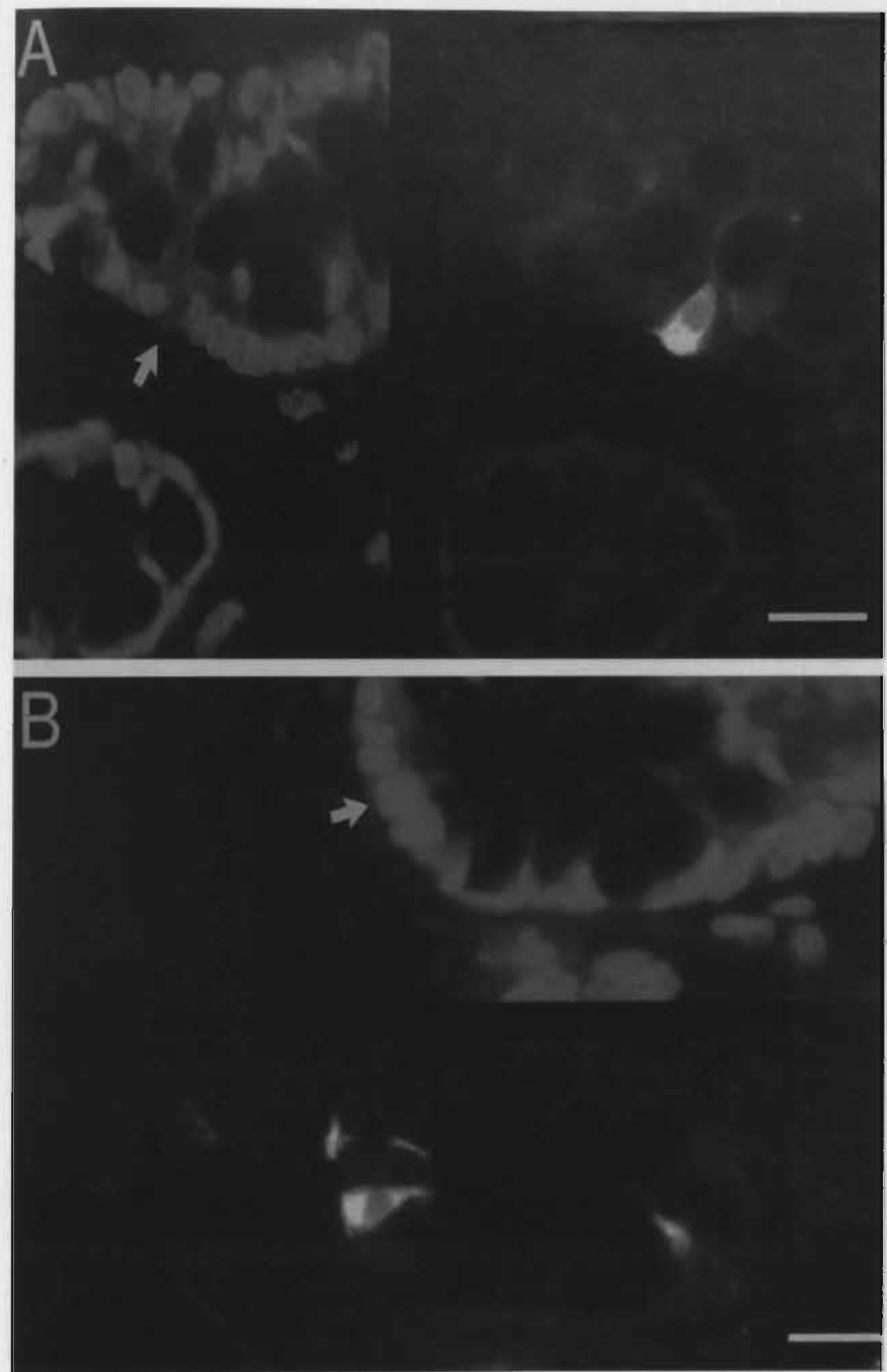

PLATE 1. Double indirect immunofluorescence staining of rat caecum for 5-bromo-2'-deoxyuridine (BrdU) positive nuclei (TRITC fluorescence, red), and serotonin containing enterochromaffin (EC) cells (FITC fluorescence, green). a. BrdU-negative EC cell, b. BrdU-positive EC cell. (Arrows, bar $=5 \mu \mathrm{m}$ ). 
The Northern blots were prehybridized overnight at $42^{\circ} \mathrm{C}$ in $50 \%$ formamide, 1 $\mathrm{M} \mathrm{NaCl}, 1 \%$ SDS, $10 \%$ dextran sulphate and $0.1 \mathrm{mg} / \mathrm{ml}$ denatured salmon sperm DNA. For hybridization, denatured chromogranin $A$ and $\beta$ actin probes radiolabeled with ${ }^{32} \mathrm{P}$ by the random primer method $(31,32)$ were added. After overnight incubation, the filters were washed in $2 \times S S C\left(2 \times 15^{\prime}, \mathrm{RT}\right), 2 \mathrm{xSSC}$ and $1 \% \operatorname{SDS}\left(2 \times 15^{\prime}, 60^{\circ} \mathrm{C}\right)$. The filters were exposed to Kodak-XAR film, at $-70^{\circ} \mathrm{C}$ with an Ilford intensifying screen. Autoradiograms were scanned by laserdensitometry (Ultrascan 2202, LKB, Sweden). The relative amount of chromogranin A mRNA was calculated as the ratio of the densitometrically measured hybridization signals of chromogranin $A$ and $\beta$ actin.

\subsubsection{Electron microscopy}

Cells or tissues were fixed for $2 \mathrm{hrs}$. in $0.1 \mathrm{M}$ phosphate buffered $2.5 \%$ glutaraldehyde, postfixed ( $1 \mathrm{hr}$.) in $0.1 \mathrm{M}$ phosphate buffered $1 \%$ osmiumtetroxide, dehydrated in graded ethanol series and embedded in Epon. Ultrathin sections were stained with uranyl acetate and lead citrate.

To study the interaction between NCI-H716 cells and fibroblasts, co-cultures of confluent fibroblast feeder-layers and tumor cells were grown on Thermanox coverslips (Nunc Inc., Naperville, Ill., USA), and processed accordingly.

\subsection{Results}

\subsubsection{Cell culture}

$\mathrm{NCI}-\mathrm{H} 716$ cells in vitro grew in suspension as floating aggregates. Adherent growth could be achieved by coating the culture vessels with type IV collagen, which resulted in cell attachment and growth in sheets and three-dimensional cell clusters. This interaction with type IV collagen appeared to be $\mathrm{Ca}^{2+}$ and $\mathrm{Mg}^{2+}$ dependent. Treatment of type IV collagen coated surfaces with a polyclonal rabbit anti-type IV collagen antibody did not block cell adhesion. This antibody is directed against epitopes in the triple helix domain and is immunoreactive with reduced and non-reduced type IV collagen (26). Reduction of type IV collagen with $110 \mathrm{mM}$ DTT and $120 \mathrm{mM}$ iodoacetamide, abolished cell adhesion, although type IV collagen immunoreactivity could still be demonstrated on the coated surface. This indicates that cell adhesion is mediated by the globular carboxy-terminal domain of the type IV collagen molecule, where disulfide bonds are present to stabilize the associations between collagen molecules $(33,34)$.

Coating of culturing vessels with type I or III collagen, laminin, fibronectin or HSPG did not result in cell adhesion. Culturing on the basement membrane side of stripped amnion membranes resulted in good attachment of the cells. Moderate attachment was observed on extracellular matrix prepared from colonic 

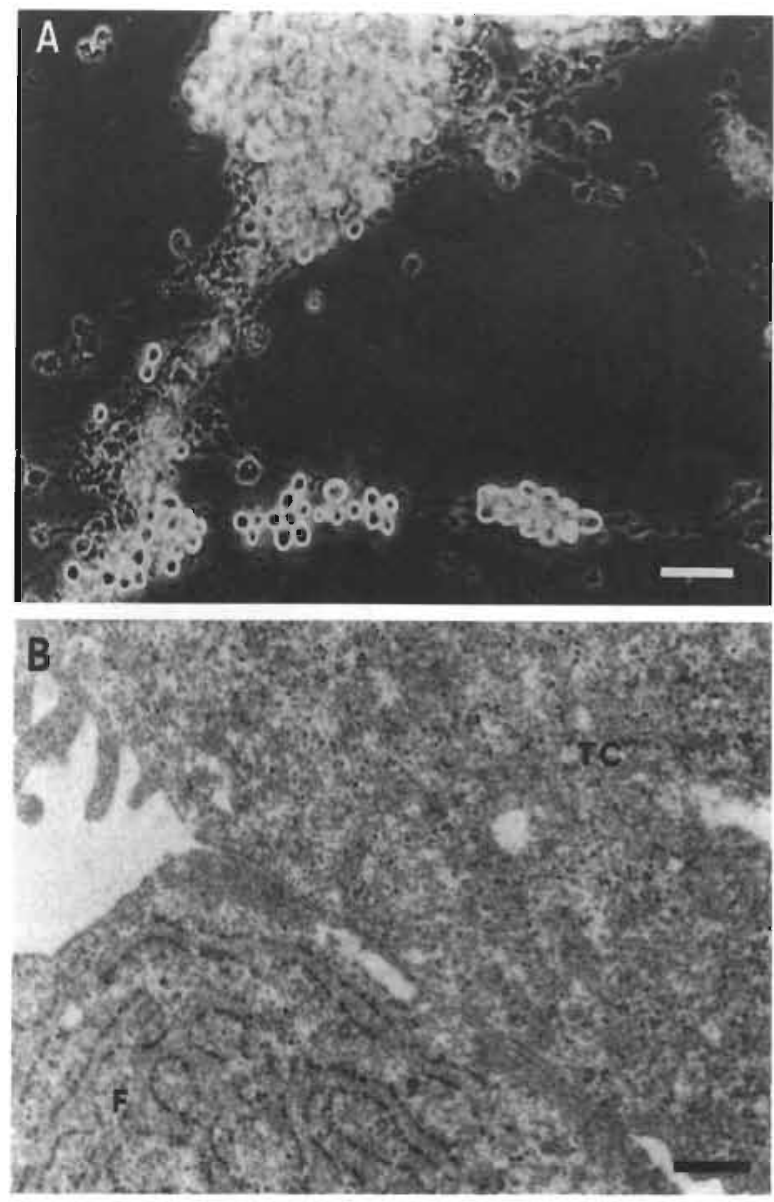

Figure 1. a. Selective adherence of NCI-H716 cells to feeder layers of fibroblasts. This specific interaction occurs independent of the type of fibroblasts. No attachment is observed to the fibroblast-free culturing surface (bar $=60 \mu \mathrm{m}$ ). b. Transmission electron micrograph demonstrating the close intercellular contact between a NCI-H716 tumor cell (TC) and a fibroblast (F). The contact is of a non-junctional type. No extracellular matrix is deposited at the intercellular interface. (bar $=420 \mathrm{~nm}$ ).

mucosa. When cells were grown on feeder-layers of fetal rat mesenchyme and various types of human fibroblasts (irrespective of type), this resulted in firm and selective adherence to the mesenchymal cells (Fig. 1a). NCI-H716 cell attachment was also observed on surfaces conditioned by fibroblasts. Ultrastructural observations demonstrated close cell contacts of a non-junctional type 

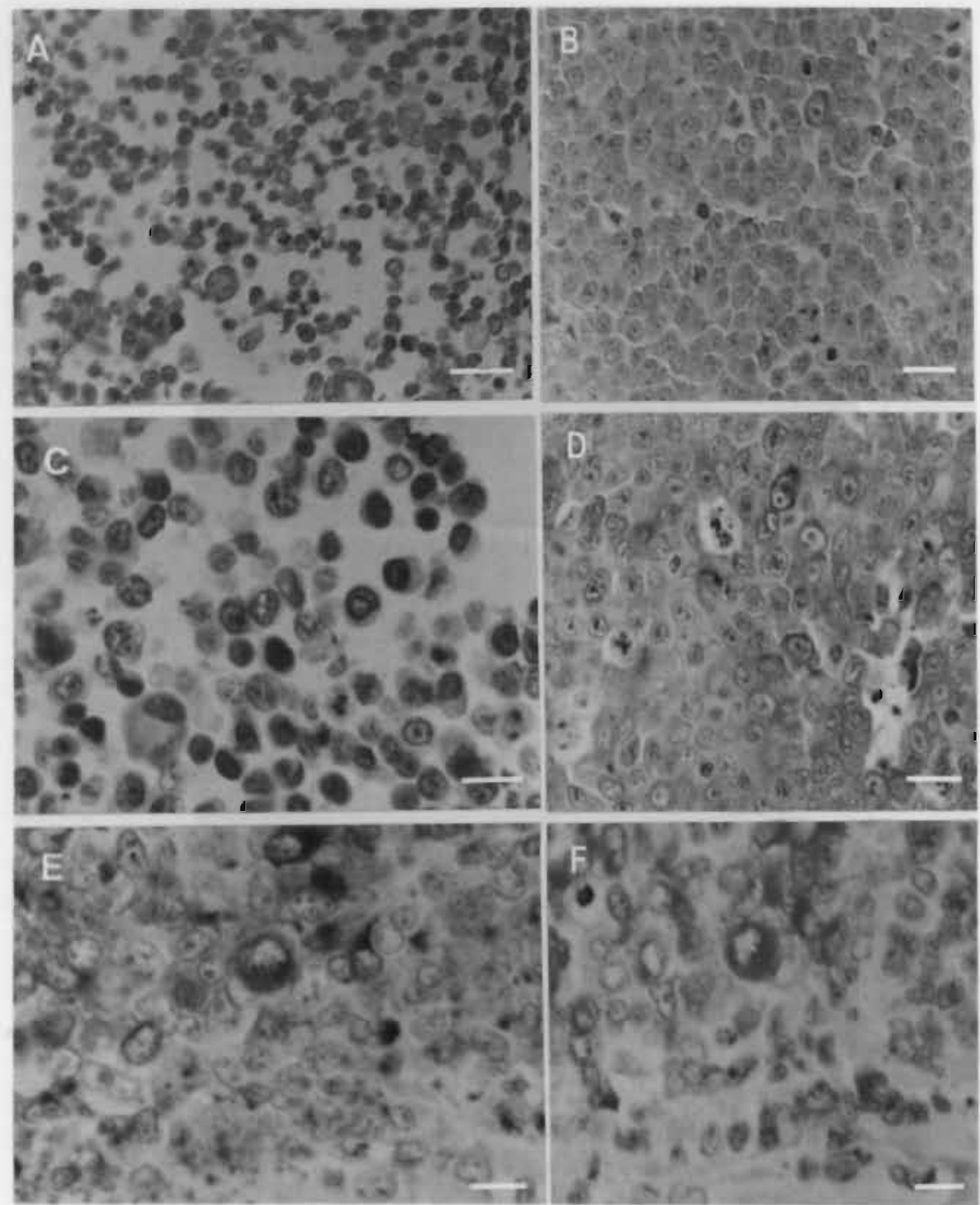

PLATE 2. Endocrine differentiation in NCl-H716 cells growing in vitro (in suspension/altached to type IV collagen, (a \& c)) and in vivo (in a subcutaneous xenograft, (b \& d)), as expressed by immunoreactivity for chromogranin A (a \& b) and synaptophysin (c \& d). Endocrine differentiation in NCl-H716 cells greatly increases in vivo (indirect immunoperoxidase with $\mathrm{DAB}$, bar $=30 \mu \mathrm{m}$ (a\&b) and $24 \mu \mathrm{m}$ (c\&d)).

Serial paraffin sections $(2 \mu \mathrm{m})$ of a NCI-H716 caecal intramural xenograft stained immunohistochemically for chromogranin A (e) and Parlam $3 / 9$ (f). identifying "amphicrine" cells, with expression of both endo- and exocrine markers. e. Indirect immunoperoxidase with DAB. (bar $=18 \mu \mathrm{m})$. f. Indirect alkaline phosphatase with Vector Red (Vector Laboratories, Burlingame. USA) (bar $=18 \mu \mathrm{m})$. 
between NCI-H716 cells and mesenchymal cells (Fig. 1b). Similar close contacts were also seen between tumor cells and these appeared to increase in number when they were cultured on feeder-layers of fibroblasts. No extracellular matrix components appeared to be deposited at the interface between epithelial and mesenchymal cells.

NCI-H716 cells grown in suspension showed a low level of L-CAM (E-cadherin, uvomorulin (35)) expression on the plasma membrane. L-CAM expression increased by culturing on aminion membranes (Fig. 2a), indicating an increase in intercellular adhesion. Integrin immunoreactivity was found independent of culturing conditions. The cells strongly expressed $\alpha 2 \beta 1$ (Fig. 2b), which has been shown to be a cell surface receptor for collagen types I, II, III and IV (36-39) or for both collagen and laminin, depending on the cell type $(40,41) . \alpha 3 \beta 1$, a receptor for collagen, laminin and fibronectin (42), was only weakly expressed. $\beta 3$ integrin receptors, interactive with several ligands (e.g. vitronectin, fibrinogen, thrombospondin (43)), were also strongly expressed. $\mathrm{NCl}-\mathrm{H} 716$ cells did not express $\alpha 6 \beta 1$, which has been identified as laminin receptor (44).

\subsubsection{Xenografts}

All 6 mice inoculated subcutaneously (s.c.) developed tumors after an average period of 5 weeks. Of the 6 mice inoculated intracaecally, 4 were sacrificed after 8 weeks but did not show tumorgrowth. The remaining 2 mice were sacrificed after 16 weeks and showed tumorgrowth in one case. Histology of subcutaneous and intracaecal xenografts was identical, showing a poorly differentiated adenocarcinoma (Colorplate 3, page 101).

\subsubsection{Phenotyping}

Endocrine differentiation was demonstrated by immunostaining for CGA, and by electron microscopy (dense core neurosecretory granules, $\emptyset$ approximately $200 \mathrm{~nm}$ ) (Fig. 3). CGA expression was sporadically observed in cells growing in suspension ( $<1 \%$ of the cells) but was strongly enhanced in xenografts $(>50 \%$ of the cells) (Colorplate 3). Modifications of the culture medium did not lead to induction of the endocrine phenotype. In proliferation restricting conditions (medium with dialyzed serum or serumfree medium), cell growth was clearly impaired but this was not associated with altered CGA expression.

Endocrine characteristics were considerably enhanced by culturing on fibroblasts, colonic mucosal lamina propria and amnion (Colorplate 3) (Table 2). Cell-adhesion to type IV collagen alone or in combination with laminin did not lead to enhanced endocrine differentiation, whereas adhesion to a combination of type IV collagen and HSPG resulted in significant increase of CGA immunoreactivity (Colorplate 3). Neither adhesion to surfaces conditioned by fibroblasts nor culturing in fibroblast-conditioned media caused any induction 

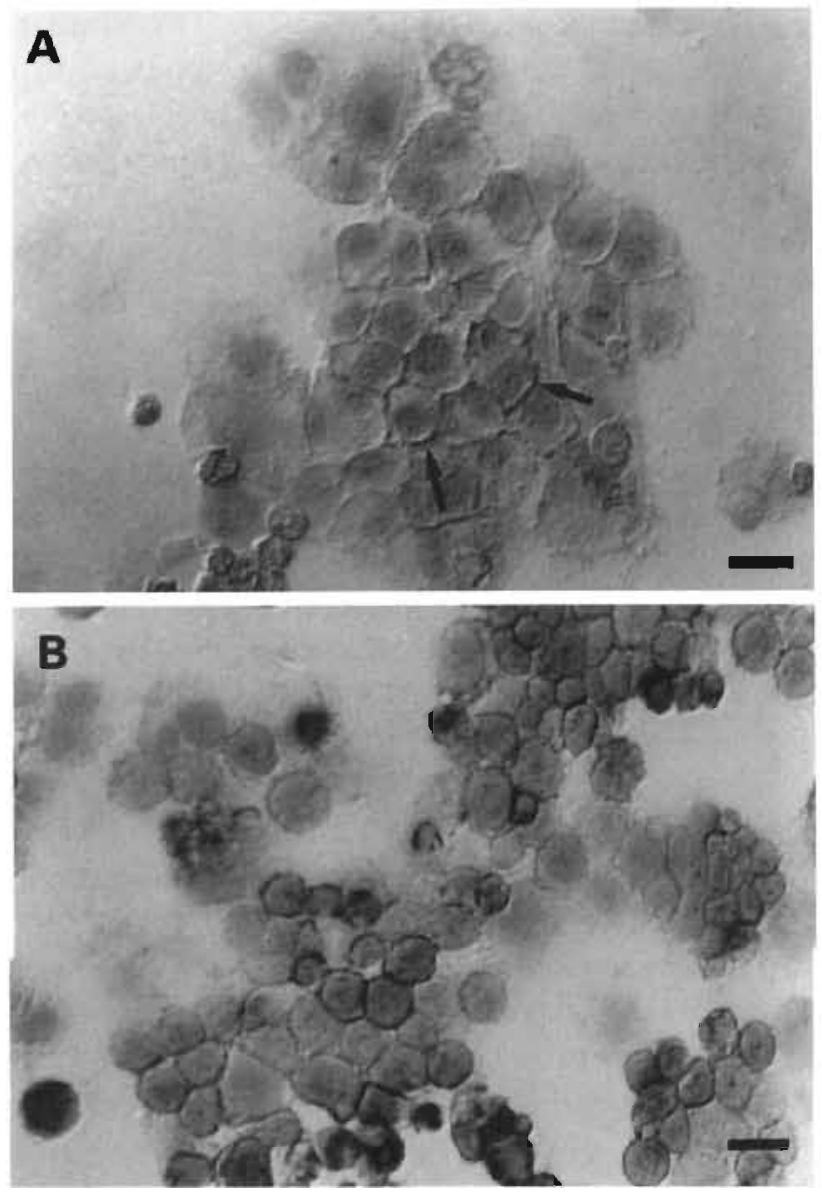

Figure 2. Expression of cell-cell and cell-stromal adhesion molecules. a. Membranous intercellular expression of L-CAM (arrows) on NCI-H716 cells cultured on amnion membranes. $\mathbf{b}$. Strong expression of the $\alpha 2 \beta 1$ (VLA2) integrin receptor in a similar pattem. (indirect immunoperoxidase with $\mathrm{DAB}$, bars = $25 \mu \mathrm{m})$.

of endocrine differentiation. Endocrine features were slightly increased by culturing in Vitrogen 100 and strongly by culturing in basement membrane Matrigel (Colorplate 3 ). When cells were cultured on type IV collagen coated surfaces in defined serumfree medium, addition of $\mathrm{bFGF}(10 \mathrm{ng} / \mathrm{ml})$ resulted in enhanced endocrine differentiation (Fig. 4), whereas TGF $\beta$ had no effect. 


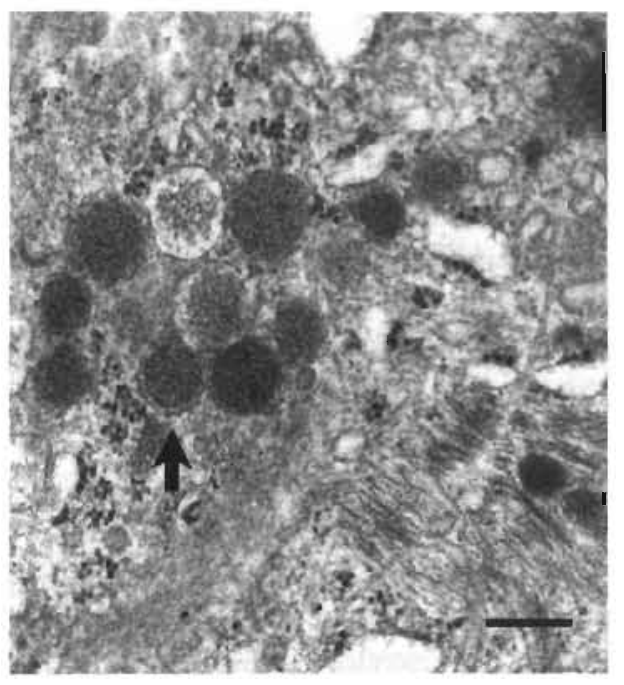

Figure 3. Transmission electron micrograph of a $\mathrm{NCl}$-H716 cell containing a cluster of dense-core secretory granules with an average diameter of $200 \mathrm{~nm}$ (arrow) $($ bar $=200 \mathrm{~nm})$.

$$
\mathrm{NCl}-\mathrm{H} 716
$$

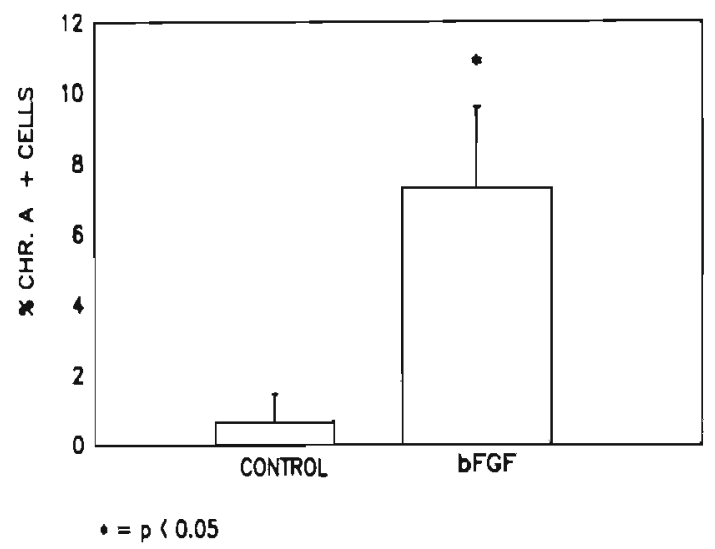

Figure 4. Increased immunohistochemical expression of chromogranin A in NCl-H716 cells cultured for 5 days on type IV collagen coated surfaces in defined, serumfree medium with bFGF (10 ng/ml), as compared to control cells. Bars represent the mean percentage and standard deviation of chromogranin A positive cells in three experiments. ( $p<0.05$; $t$-test for independent groups with separate variances). 


\subsubsection{Northern Blot Analysis}

As reported previously (24), the cDNA probe for human CGA strongly hybridized with RNA extracted from a s.c. xenograft of NCI-H716 and from the human pheochromocytoma. A sequence of approximately $2.1 \mathrm{~kb}$ was detected, which is the expected size of the messenger (45). Only a weak signal was found in RNA from cultured NCI-H716 cells, whereas the non-endocrine colon cancer cell line HT-29 was negative. The CGA/ $\beta$ actin mRNA ratio in vivo showed an approximately ten-fold increase compared with cultured cells (Fig. 5).

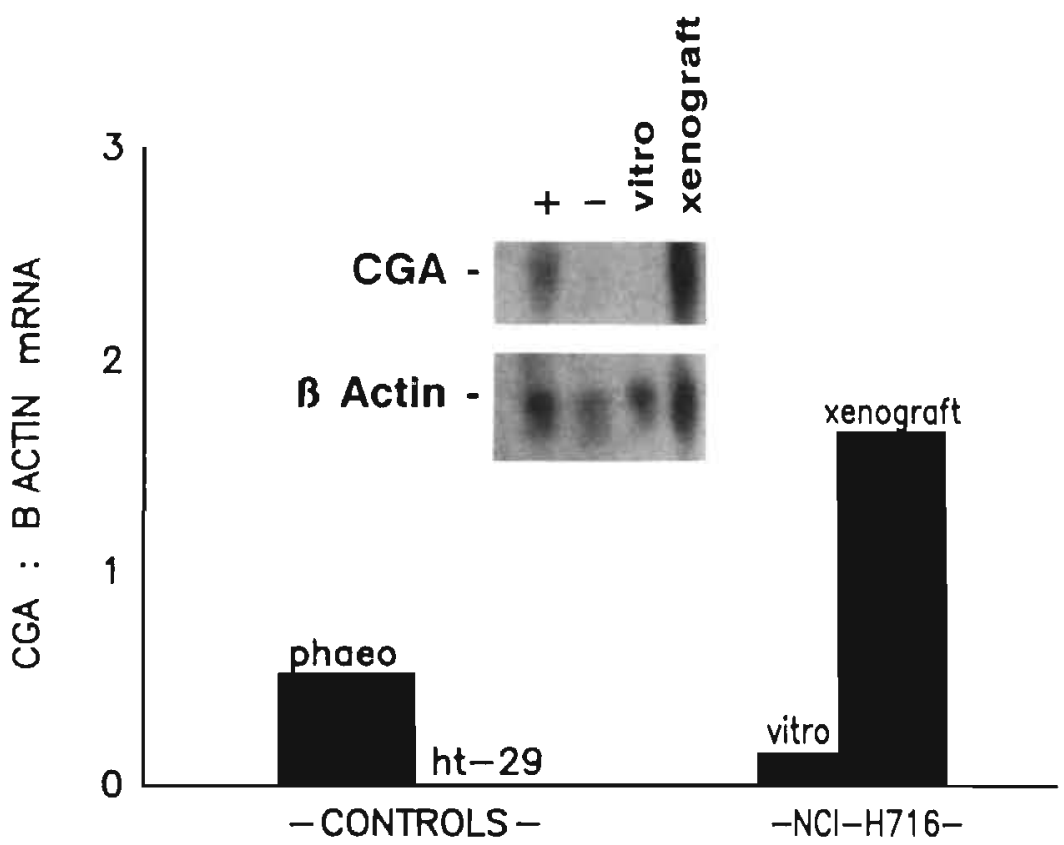

Figure 5. Northem blot analysis. Comparison of chromogranin A (CGA) mRNA expression in NCl-H716 cells growing in vitro under standard conditions and in a subcutaneous xenograft. A human pheochromocytoma was used as a positive control (+); HT-29 colon carcinoma cells as a negative control (-). Hybridization for $\beta$ actin was performed as an intemal standard for the amount of RNA. Bars represent densitometric quantification of CGA mRNA, corrected for $\beta$ actin mRNA (CGA: $\beta$ actin ratio). The amount of mRNA for CGA in NCI-H716 cells shows an approximate 10-fold increase in vivo vs. in vitro. 


\subsection{Discussion}

For the study of endocrine differentiation in normal and neoplastic intestinal epithelium in vitro models are indispensable. Colorectal adenocarcinoma cell lines with endocrine differentiation are extremely rare, despite the relatively high incidence of endocrine differentiation in colorectal adenocarcinomas (46). Apart from the NCI-H716 cell line, derived from a poorly differentiated caecal adenocarcinoma with endocrine characteristics (23), the only other adenocarcinoma cell line of human origin convincingly demonstrating endocrine features is the HRA-19 cell line, which was derived from a moderately differentiated rectal adenocarcinoma (21). This cell line contains cells of each of the three large intestinal lineages (5), making it an attractive model to study differentiation in colorectal epithelium. However, endocrine cells are only encountered in HRA19 xenografts in nude mice, suggesting that some factor present in vivo may be necessary to induce the endocrine phenotype. Recently, it was shown that endocrine differentiation of HRA-19 cells in xenografts depends on direct contact between tumor cells and host stromal cells (47). In both murine and human cells systems, extracellular matrix components have been demonstrated to play an important role on intestinal epithelial differentiation $(22,48-50)$. Similar results have been obtained from embryologic studies involving recombination of embryonal intestinal epithelium with mesenchyme from various parts of the developing intestine $(51,52)$. These studies have demonstrated a leading role for mesenchyme on the evolution of the endocrine phenotype. Endocrine differentiation can be induced when epithelium is recombined with the appropriate type of mesenchyme.

The present studies on $\mathrm{NCl}-\mathrm{H} 716$ cells primarily focussed on the mechanisms involved in the induction of endocrine differentiation. Interestingly, as in the HRA-19 model, expression of a general neuroendocrine marker was significantly more intense in xenografts than in cultured cells, suggesting a role for the extracellular matrix or mesenchymal stroma in induction of the endocrine phenotype. We tested this hypothesis by performing differentiation induction experiments in vitro. The main purpose was to identify which factor(s) would be capable of enhancing endocrine differentiation in vitro. In the experiments either the culture medium was modified, by adding differentiation inducing agents, or the culturing substrate was modified to expose several extracellular matrix components.

None of the agents which are known to induce differentiation in colon cancer cell lines augmented endocrine differentiation. Growth restriction did not lead to altered differentiation either.

The experimental modifications of the culturing substrate indicate that cell-adhesion is a prerequisite for induction of the endocrine phenotype. When cells were seeded on surfaces coated with type I/III collagen, laminin, fibronectin or 
HSPG, the lack of cell adhesion was parallelled by the absence of phenotypical changes. However, cell-adhesion to an individual extracellular matrix component alone also failed to induce endocrine differentiation. On type IV collagen, NCI-H716 cells did adhere, but did not show significant increase of endocrine characteristics. The cells also adhered to a combination of type IV collagen and laminin, but enhanced endocrine differentiation was not seen. In combination with the absence of the $\alpha 6 \beta 1$ laminin receptor on NCl-H7 16 cells, this finding does not substantiate a major role for laminin in the induction of endocrine differentiation.

However, growth on surfaces coated with a combination of type IV collagen and HSPG resulted in both adhesion and induction of endocrine characteristics. Apparently, type IV collagen is necessary for cell-adhesion and HSPG induces differentiation. Contrasting with individual ECM components, endocrine differentiation was found to be highly stimulated by cell growth on intact, naturally occurring stroma (amnionic membranes, stripped colonic mucosa, fibroblasts). This indicates a role for cell surface adhesion molecules in mediating the induction of endocrine differention. Extracellular matrix receptors differ from other cell-surface receptors (e.g. peptide hormone receptors) in their lower binding affinity, and much higher concentration at the cell- surface (53). Therefore these receptors probably cooperate in binding cells to combinations of matrix ligands rather than to individual components. In support of this, individual extracellular matrix components usually fail to elicit the cellular responses induced by the same components in a complex matrix. An extracellular matrix did not appear to be indispensable: co-culturing on feeder-layers of fibroblasts induced endocrine differentiation, without involvement of extracellular matrix components at the intercellular interface. The inductive effect of fibroblasts seemed to be primarily dependent on the close contact with the tumor cells: culturing of tumorcells on type IV collagen coated surfaces in fibroblast conditioned media did not induce endocrine differentiation.

The enhancement of endocrine differentiation by direct contact with fibroblasts, and the absence of this effect when employing fibroblast-conditioned culturing media suggests that one or more factors produced by cultured fibroblasts could have local paracrine activity as a differentiation inducer. Such a factor would be present in too low concentrations in conditioned medium, but would accumulate in sufficient amount in extracellular matrix to account for the differentiation inducing effect of complex stroma. One possible candidate is bFGF. This factor is present in several mesenchymal tissues, associated with mesoderm and neuroectoderm-derived cells, and their extracellular marrices $(54,55)$. It is not actively secreted owing to the lack of a signaling peptide (56) and therefore it remains bound to heparin-like ECM molecules such as the basement membrane component HSPG (57), from where it can exert its specific effects (58). The surmised role of a factor as bFGF is supported by the observed increase in 
endocrine differentiation of NCI-H716 cells grown in direct contact with extracted HSPG and in basement membrane Matrigel. The latter substance contains basement membrane components and several growth factors among which bFGF. Moreover, a specific effect of bFGF was confirmed by the observed increase of CGA expression, after addition of bFGF to cells growing in serumfree defined culture medium.

As the mesenchymal origin of bFGF was not investigated in our study, an alternative source for such a factor can not be excluded. NCl-H716 cells are known to produce substances, which are involved in autocrine grow th regulation (59). Conceivably, these tumor cells could also produce factors inducing differentiation. In this respect, it is noteworthy that bFGF has been demonstrated in secretory granules of adrenal medullary chromaffin cells (60), where it maintains differentiation by enhancing survival and transmitter storage of cultured cells (61). If this would also apply to NCI-H716 cells, direct contact with ECM components might cause release of similar factors from the tumor cells, and lead to enhanced endocrine features by auto- or paracrine mechanisms. The presence of heparin-like growth factor binding substances in the ECM might modulate this response.

In summary, in the NCI-H716 cell line, endocrine differentiation is readily observed in vivo but is scarce in vitro. Endocrine differentiation can be induced in vitro when tumor cells interact directly with specific extracted basement membrane components, natural extracellular matrix or mesenchymal cells. Therefore, the induction of endocrine differentiation involves a combination of cell adhesion, probably mediated by cell adhesion molecules of the integrin family, and the influence of local factors which function by auto- or paracrine mechanisms and/or are bound to extracellular matrix molecules. 


\subsection{REFERENCES}

1. Chang WW, Leblond CP. A unitarian theory of the origin of the three populations of epithelial cells in the mouse large intestine. Anat Rec 1971;169:293.

2. Cheng $\mathrm{H}$, Leblond $\mathrm{CP}$. Origin, differentiation and renewal of the four main epithelial cell types in the mouse small intestine $\mathrm{V}$. Unitarian theory of origin of the four epithelial cell types. Am J Anat 1974; 141:537-562.

3. Cox WF, Pierce GB. The endodermal origin of the endocrine cells of an adenocarcinoma of the colon of the rat. Cancer 1982;50:1530-1538.

4. Andrew A, Kramer B, Rawdon BB. The embryonic origin of endocrine cells of the gastrointestinal tract. Gen Comp Endocrinology 1982;47:249-265.

5. Kirkland SC. Clonal origin of columnar, mucous, and endocrine cell lineages in human colorectal epithelium. Cancer 1988;61:1359-1363.

6. Griffiths DFR, Davies SJ, Williams D, Williams GT, Williams ED. Demonstration of somatic mutation and colonic crypt clonality by X-linked enzyme histochemistry. Nature 1988; 333:46I-463.

7. Cohn SM, Roth KA, Birkenmeier EH, Gordon Л. Temporal and spatial patterns of transgene expression in aging adult mice provide insights about the origins, organization, and differentiation of the intestinal epithelium. Proc Nat Acad Sci USA 1991;88:1034-1038.

8. Sjölund K, Sandén G, Håkanson R, Sundler F. Endocrine cells in human intestine: an immunocytochemical study. Gastroenterology 1983;85:1120-1130.

9. Lewin KJ. The endocrine cells of the gastrointestinal tract. Part l. The normal endocrine cells and their hyperplasias. Pathol Annu 1986;21 Part 1:1-27.

10. Solcia E, Usellini L, Buffa R, Rindi G, Villani L, Zampanti C. Silini E. Endocrine cells producing regulatory peptides. Experientia 1987;43:839-850.

11. Johnson LR. Regulation of gastrointestinal mucosal growth. Physiol Rev 1988;68:456502.

12. Dayal Y, De Lellis RA, Wolfe H. Hyperplastic lesions of the gastrointestinal endocrine cells. Amer J Surg Pathol 1987;11 (Supp.I):87-101.

13. Bosman FT. Neuroendocrine cells in non-neuroendocrine tumours. In: Evolution and tumour pathology of the neuroendocrine system. FalkmerS, Hâkanson R, Sundler Feds, Amsterdam New York Oxford, Elsevier, 1984, pp.519-543.

14. Redman BG, Pazdur R. Colonic small cell undifferentiated carcinoma: a distinct pathological diagnosis with therapeutic implications. Am J Gastroenterol 1987;82:382-385.

15. Ho SB, Itzkowitz SH, Friera AM, Jiang S-H, Kim YS. Cell lineage markers in premalignant and malignant colonic mucosa. Gastroenterology 1989;97:392-404.

16. Arends JW, Wiggers T, Verstijnen C, Bosman FT. The occurrence and clinicopathological significance of serotonin immunoreactive cells in large bowel carcinoma. J Pathol 1986; 149:97-102.

17. Jansson D, Gould VE, Gooch GT, Rittenhouse HG, Sik Shin S, Manderino GL, Tomita JT, Staren ED. Immunohistochemical analysis of colon carcinomas applying exocrine and neuroendocrine markers. APMIS 1988;96:1129-1139.

18. Hamada Y, Oishi A, Shoje T, Takada H, Yamamura M, Hioki K, Yamamoto M. Endocrine cells and prognosis in patients with colorectal carcinoma. Cancer 1992;69:2641-2646. 
19. De Bruine AP, Dinjens WNM, Zijlema JHL, Lenders M-H, Bosman FT. Renewal of enterochromaffin cells in the rat caecum. Anat Rec 1992;233:75-82.

20. Hoosein NM, Kiener PA, Curry RC, Brattain MG. Evidence for autocrine growth stimulation of cultured tumor cells by a gastrin/cholecystokinin-like peptide. Exp Cell Res 1990; 186:15-21.

21. Kirkland SC. Endocrine differentiation by a human rectal adenocarcinoma cell line (HRA-19). Differentiation 1986;33:148-155.

22. Kramer B, Andrew A, Rawdon BB, Becker $P$. The effect of pancreatic mesenchyme on the differentiation of endocrine cells from gastric endoderm. Development 1987; 100:661-671,

23. Park J-G, Oie HK, Sugarbaker PH, Henslee JG, Chen T-R, Johnson BE, Gazdar A. Characteristics of cell lines established from human colorectal carcinoma. Cancer Res 1987:47:6710-6718.

24. De Bruïne AP, Dinjens WNM, Pijls M, Van der Linden E, Rousch M, Moerkerk PT, De Goeij AFPM, Bosman FT. NCl-H7I6 cells as a model for endocrine differentiation in colorectal cancer. Virchows Arch B Cell Pathol 1992;62:31 1-320.

25. Wiedenmann B, Huttner WB. Synaptophysin and chromogranins/secretogranins - widespread constituents of distinct types of neuroendocrine vesicles and new tools in tumor diagnosis. Virchows Arch B cell Pathol 1989;58:95-121.

26. Havenith MG, Cleutjens JPM, Beek C, Van der Linden E, De Goeij AFPM, Bosman FT. Human specific anti type IV collagen monoclonal antibodies, characterization and immunohistochemical application. Histochemistry 1987;87:123-128.

27. Whitehead RH, Brown A, Bhathal PS. A method for the isolation and culture of human colonic crypts in collagen gels. In Vitro Cell \& Dev Biology 1987;23:436-442.

28. Fukamachi $\mathrm{H}$, Mizuno T. Gland formation of human colon cancer cells combined with foetal rat mesenchyme in organ culture: an ultrastructural study. J Cell Science 1987;87:615-621.

29. Dinjens WN, Ten Kate J, Kirch JA, Tanke HJ, Van der Linden EP, Van den Ingh HF, Van Steenbrugge GJ, Meera Khan P, Bosman FT. Adenosine deaminase complexing protein (ADCP) expression and metastatic potential in prostatic adenocarcinomas. $\mathrm{J}$ Pathol 1990;160:195-201.

30. Lloyd RV, Wilson BS. Specific endocrine tissue marker defined by a monoclonal antibody. Science 1983;222:628-630.

31. Feinberg AP, Vogelstein B. "A technique for radiolabeling DNA restriction endonuclease fragments to high specific activity". Addendum. Anal Biochem 1984;137:266267.

32. Moerkerk PT, Kessels HJ, Ten Kate J, De Goeij AFPM, Bosman FT. Southem and dot blot analysis of DNA from formalin-fixed, paraffin-embedded tissue samples from colonic carcinomas. Virchows Arch B Cell Pathol 1990;58:351-355.

33. Weber S, Engel J, Wiedemann H, Glanville RW, Timpl R. Subunit structure and assembly of the globular domain of basement membrane collagen type IV. Eur J Biochem 1984;139:401-410.

34. Wieslander J, Langeveld J, Butkowski R, Jodlowski M, Noelken M, Hudson BG. Physical and immunochemical studies of the globular domain of type IV collagen. Cryptic properties of the Goodpasture antigen. J Biol Chem 1985;260:8564-8570.

35. Takeichi M. Cadherin cell adhesion receptors as a morphogenetic regulator. Science 1991;251:1451-1455. 
36. Santoro SA, Rajpara SM, Staatz WD, Woods IW. Isolation and characterization of a platelet surface collagen binding complex related to VLA-2. Biochem Biophys Res Com 1988; 153:217-223.

37. Staatz WD, Rajpara SM, Wayner EA, Carter WG, Santoro SA. The membrane glycoprotein Ia-Пla (VLA-2) complex mediates the $\mathrm{Mg}^{+}$dependent adhesion of platelets 10 collagen. J Cell Biol 1989;108:1917-1924.

38. Koretz K, Schlag P, Boumsell L, Möller P. Expression of VLA- $\alpha 2$, VLA- $\alpha 6$, and VLA- $\beta 1$ chains in normal mucosa and adenomas of the colon, and in colon carcinomas and their liver metastases. Am J Pathol 1991;138:741-750.

39. Staatz WD, Fok KF, Zutter MM, Adams SP, Rodriguez BA, Santoro SA. Identification of a tetrapeptide recugnition sequence for the alpha 2 beta 1 integrin in collagen. J Biol Chem 1991;266:7363-7367.

40. Languino LR, Gehlsen KR, Wayner E. Carter WG, Engvall E, Ruoslahti E. Endothelial cells use $\alpha 2 \beta 1$ integrin as a laminin receptor. J Cell Biol 1989;109:2455-2462.

41. Elices MJ, Hemler ME. The human integrin VLA-2 is a collagen receptor on some cells and a collagen/laminin receptor on others. Proc Nat Acad Sci USA 1989;86:9906-9910.

42. Springer TA. Adhesion receptors of the immune system. Nature 1990;346:425-434.

43. Hynes RO. Integrins: a family of cell surface receptors. Cell 1987;48:549-554.

44. Sonnenberg A, Modderman PW, Hogervorst F. Laminin receptor on platelets is the integrin VLA-6. Nature 1988;336:487-489.

45. Helman LJ, Ahn TG, Levine MA, Allison A, Cohen PS, Cooper MJ, Cohn DV, Israel MA. Molecular cloning and primary structure of human chromogranin A (secretory protein I) cDNA. J Biol Chem 1988;263: I I559-|1563.

46. Bosman FT, De Bruïne AP. Endocrine cells in non-endocrine tumors of the gut and pancreas. In: Endocrine pathology of the gut and pancreas. Dayal Y ed, Boca Raton Ann Arbor Boston, CRC Press, 1991, pp.319-338.

47. Del Buono R, Pignatelli M, Hall PA. Control of differentiation in a rectal adenocarcinoma cell line: the role of diffusable and cell-associated factors. J Pathol 1991;164:5966.

48. Stallmach A, Hahn U, Merker HJ, Hahn EG, Riecken EO. Differentiation of rat intestinal epithelial cells is induced by organotypic mesenchymal cell in vitro. Gut 1989;30:959970.

49. Hahn U, Stallmach A, Hahn EG, Riecken EO. Basement membrane components are potent promoters of rat intestinal epithelial cell differentiation in vitro. Gastroenterology 1990;98:322-335.

50. Walling JM, Blackmore M. Hickman JA, Townsend KMS. Role of extracellular matrix on the growth and differentiated phenotype of murine colonic adenocarcinoma cells in vitro. Int J Cancer 1991;47:776-783.

5I. Rawdon BB, Andrew A. Can proventricular mesenchyme promote differentiation of endocrine cells in gizzard endoderm? Cell Differ Dev 1988;25:135-143.

52. Stein B, Andrew A. Differentiation of endocrine cells in chick allantoic epithelium combined with pancreatic mesenchyme. Cell Differ Dev 1989;26:173-180.

53. Buck CA, Horwitz AF. Cell surface receptors for extracellular matrix molecules. Annu Rev Cell Biol 1987;3:179-205.

54. Gospodarowicz D. Fibroblast growth factor and its involvement in developmental processes. Curr Top Dev Biol 1990;24:57-93. 
55. Gonzalez A-M, Buscaglia M, Ong M, Baird A. Distribution of basic tibroblast growth facior in the 18-day old rat fetus: localization in the basement membranes of diverse tissues. J Cell Biol 1990;110:753-765.

56. D'Amore PA. Modes of FGF release in vivo and in vitro. Cancer Metastasis Rev 1990;9:227-238.

57. Folkman J, Klagsbrun M, Sasse J, Wadzinski MG, Ingber D, Vlodavsky I. A heparinbinding angiogenic protein -basic fibroblast growth factor- is stored within basement mebrane. Am J Pathol 1988; 130:393-400.

58. Klagsbrun M, Baird A. A dual receptor system is required for basic fibroblast growth factor activity. Cell 1991;67:229-231.

59. Kames WE Jr., Walsh JH, Wu SV, Kim RS, Martin MG, Wong HC, Mendelsohn J, Park $\mathrm{J}-\mathrm{G}$, Cuttitta F. Aulonomous proliferation of colon cancer cells that coexpress transforming growth factor $\alpha$ and its receptor. Gastroenterology 1992;102:474-485.

60. Westermann R, Johannsen M, Unsicker K, Grothe C. Basic fibroblast growth factor (bFGF) immunoreactivity is present in chromaffin granules. J Neurochem 1990;55:285292.

61. Unsicher K, Westermann R, Grothe C, Gehrke D, Böhlen P. A possible autocrine role of basic FGF for maintenance and transmitter storage of chromaffin cells. Soc Neurosci Abstr 1988; 14:301. 



\section{CHAPTER 5}

HUMAN CACO-2 CELLS

TRANSFECTED WITH c-HA-RAS

AS A MODEL FOR ENDOCRINE

DIFFERENTIATION IN THE

LARGE INTESTINE

A.P. de Bruine, J.E. de Vries, W.N.M. Dinjens, P.T. Moerkerk, E.P.M. v.d. Linden, M.M.J. Pijls, J. ten Kate, and F.T. Bosman. 


\section{$5.1 \quad$ INTRODUCTION}

In the colorectum, endocrine neoplasms in their most characteristic form are encountered as classical carcinoid tumors (1). However, endocrine differentiation in large intestinal epithelial tumors has been recognized to occur in a much wider spectrum of tumors, comprising poorly differentiated small cell undifferentiated carcinomas $(2,3)$ and mixed exocrine/endocrine carcinomas with variable numbers of endocrine tumor cells (4). In colorectal adenocarcinomas, endocrine differentiation can be found in approximately $30 \%$ of cases (5). This relatively high frequency and the fact that some reports state a poorer prognosis for colon carcinomas with endocrine cells $(6,7)$ is indicative for the potential importance of this phenomenon. The more aggressive behavior could be related to growth stimulatory effects of peptides and/or amines produced by endocrine tumorcells (8), which may act as autocrine or paracrine growth factors (9).

To study the biological relevance of endocrine differentiation in colorectal adenocarcinomas, well defined tumor models are of utmost importance. This has been hampered by the relative scarcity of colorectal adenocarcinoma cell lines with endocrine features. So far, only two colorectal cancer cell lines with endocrine differentiation have been well documented: HRA-19 (10) and NClH716 (11). In HRA-19 endocrine differentiation exclusively occurs in tumor xenografts, which are morphologically well differentiated adenocarcinomas. This finding suggests that stromal factors are involved in the induction of endocrine differentiation (12). NCI-H716 xenografts are morphologically poorly differentiated adenocarcinomas, not fully representative of the predominant type of colorectal adenocarcinoma. Endocrine differentiation is observed extensively in NCI-H716 xenografts, but can also be induced in vitro by specific extracellular matrix components (13). The availability of more cell lines, morphologically corresponding with the predominant (well differentiated) type of colorectal carcinoma and harboring all colorectal epithelial cell lineages, would be useful in order to elucidate the mechanism regulating endocrine differentiation.

In view of their high level of differentiation (14), we chose to investigate Caco-2 cells for endocrine characteristics. Initial experiments demonstrated that under standard conditions of xenografting a low take rate is attained. We therefore transfected these cells with a point mutated c-Harvey (Ha)-Ras-gene, as Ras overexpression has been associated with tumor progression (15), metastatic capacity $(16,17)$, and endocrine differentiation $(18,19)$. The present report describes the c-Ha-Ras transfection of Caco-2, the properties of the obtained cell lines and their use as a model to study endocrine differentiation in colorectal cancer. 


\subsection{MATERIALS AND METHODS}

\subsubsection{Tumorcells}

Caco-2 cells were purchased from the American Type Culture Collection (ATCC, Rockville, Maryland, USA), Caco-2 EJ6 cells were established from this native cell line by transfection.

\subsubsection{Transfection experiments}

The plasmid $\mathrm{pSV}_{2}$ neo, containing the neomycin gene $(20)$, the plasmid $\mathrm{pSV}_{2}$ neoEJ, containing a $6.6 \mathrm{~kb}$ genomic Bam $\mathrm{HI}$ fragment of the c-Ha-Ras oncogene with a $\mathrm{G}$ to T mutation in codon $12(21)$, and the plasmid $\mathrm{pSV}_{2}$ neoCO, containing the $6.6 \mathrm{~kb}$ genomic Bam HI fragment of the c-Ha-Ras proto oncogene (22), were a kind gift of Prof.Dr. Cerutti (Swiss Institute for Experimental Cancer Research, CH-1066 Epalinges, Switzerland). Plasmids were isolated by the alkaline lysis method (23) and further purified by precipitation with $7.5 \mathrm{M}$ ammoniumacetate $\left(\mathrm{NH}_{4} \mathrm{Ac}\right)$.

For transfection, $5 \mu \mathrm{g}$ of plasmid DNA was coprecipitated with calciumphosphate according to the protocol of Graham and van der Eb (24), with the modifications described by Chen and Okayama (25). The addition of the plasmid/caiciumchloride mixture to N,N-bis(2-hydroxyethyl)-2-aminoethanesulfonic acid buffered saline was carried out in continuous airflow. It was added to $2 \times 10^{5}$ exponential growing Caco-2 cells in a $75 \mathrm{~cm}^{2}$ culture flask with $10 \mathrm{ml}$ medium. After two days, the cells were trypsinized and plated into 96-well plates, where selection was started by adding $800 \mu \mathrm{g} / \mathrm{ml}$ of gentamycin (G418, GIBCO, Paisley, Scotland) to the culture medium. After three weeks, selection was completed. Only wells containing one colony were used for further experiments. In the present study, the clones Caco-2 EJ6 (containing pSV ${ }_{2}$ neoEJ),

TABLE 1. Tumor take rate upon xenografting under various conditions

\begin{tabular}{lllll}
\hline Cell line & $\begin{array}{l}\text { Standard } \\
\text { conditions }\end{array}$ & $\begin{array}{l}\text { Vitrogen } 100 \\
\text { gel }\end{array}$ & $\begin{array}{l}\text { Vitrogen } 100 \\
\text { soluble }\end{array}$ & $\begin{array}{l}\text { Vitrogen } \\
+\alpha A S G M 1\end{array}$ \\
\hline Caco-2 & $0 / 8$ & $3 / 3(12)$ & $1 / 1(19)$ & $2 / 2(2)$ \\
Cac0-2 EJ6 & $14 / 14(4)$ & $3 / 3(4)$ & $1 / 1(5)$ & $1 / 1(2)$ \\
Cac0-2 CO1 & $0 / 2$ & n.t. & n.t. & n.t. \\
Caco-2 CO2 & $0 / 2$ & n.t. & n.t. & n.t. \\
Caco-2 D5 Neo & $0 / 3$ & n.t. & n.t. & n.t. \\
\hline
\end{tabular}

No. of animals with tumors obtained per total no. of animals inoculated; between brackets the latency time (in weeks) is indicated; n.t. = not tested. 
Caco-2 CO1 and $\mathrm{Caco}-2 \mathrm{CO} 2$ (containing $\mathrm{pSV}_{2}$ neoCO), and Caco-2 D5 Neo (containing $\mathrm{pSV}_{2}$ neo), were used (Table 1).

\subsubsection{Southern blot analysis}

After lysis of cells with $1 \%(\mathrm{v} / \mathrm{v})$ proteinase $\mathrm{K}(10 \mathrm{mg} / \mathrm{ml})$ and $0.5 \%$ sodiumdodecylsulfate (SDS) $\left(1 \mathrm{hr} ., 56^{\circ} \mathrm{C}\right)$, DNA was extracted with a mixture of phenol, chloroform and isoamylalcohol (25:24:1 v/v), followed by chloroform and isoamylalcohol $(24: 1 \mathrm{v} / \mathrm{v})$, and precipitated with isopropanol and $0.1 \mathrm{MI}$ sodiumacetate $(\mathrm{NaAc})$. The pellet was washed with $70 \%$ ethanol, suspended in TE buffer $(10 \mathrm{mM}$ Tris $\mathrm{pH} 7.4,0.1 \mathrm{mM}$ ethylenediaminetetraacetic acid (EDTA)) and stored at $4^{\circ} \mathrm{C}$.

Bam HI digested DNA was size-fractionated by overnight electrophoresis at $23 \mathrm{~V}$ in $0.7 \%$ agarose gel in TAE buffer ( $0.04 \mathrm{M}$ Tris-acetate, $0.001 \mathrm{M} \mathrm{EDTA})$ and transferred to Hybond $\mathrm{N}+$ filters by ovemight blotting (RT). Filters were neutralized ( $30 \mathrm{sec}$. in $2 \mathrm{xSSC}, 0.5 \mathrm{M}$ Tris- $\mathrm{HCl}, \mathrm{pH} 7.4$ ) and dried at $\mathrm{RT}$.

Filters were prehybridized (overnight, $42^{\circ} \mathrm{C}$ ) in $40 \%$ formamide, $1 \mathrm{M}$ sodiumchloride $(\mathrm{NaCl}), 0.05 \mathrm{M}$ sodiumphosphate, $1 \%$ SDS, $10 \%$ dextransulphate and $0.1 \mathrm{mg} / \mathrm{ml}$ denatured salmon sperm DNA. A $3 \mathrm{~kb} \mathrm{Sac} \mathrm{I} \mathrm{fragment} \mathrm{containing} \mathrm{the}$ four coding regions of the $\mathrm{c}-\mathrm{Ha}$-Ras gene was radiolabeled with ${ }^{32} \mathrm{P}$ by the random primer method $(26,27)$, and added to the hybridization mixture. Hybridization took place overnight at: $42^{\circ} \mathrm{C}$. Washing steps were $2 \times S S C\left(2 \times 5^{\prime}, \mathrm{RT}\right)$, $0.1 \times S S C$ and $1 \% \operatorname{SDS}\left(2 \times 15^{\prime}, 60^{\circ} \mathrm{C}\right)$ and $2 \times S S C\left(2 \times 15^{\prime}\right.$, RT). The filters were exposed to Kodak-XAR film, at $-70^{\circ} \mathrm{C}$ with an Ilford intensifying screen.

\subsubsection{Northern blot analysis}

RNA was extracted with the cesiumchloride gradient method after lysing cells in a $4 \mathrm{M}$ guanidinium thiocyanate solution, and precipitated with $96 \%$ ethanol/30 mM NaAc. RNA was size-fractionated by electrophoresis ( 3 hrs., RT) at $100 \mathrm{~V}$ in $1 \%$ agarose $/ 6 \%$ formaldehyde gel and transferred to Hybond $\mathrm{N}+$ filters by overnight blotting.

Ras mRNA expression was detected using the same probe as in Southern blot analysis. Parallel hybridization for $\beta$ actin mRNA was performed as an internal standard for the total amount of RNA, with a $1.3 \mathrm{~kb}$ cDNA probe (courtesy of Dr. T. Berkvens, University of Leiden). The Northem blots were prehybridized overnight at $42^{\circ} \mathrm{C}$ in $50 \%$ formamide, $1 \% \mathrm{SDS}, 1 \mathrm{M} \mathrm{NaCl}, 10 \%$ dextran sulphate and $0.1 \mathrm{mg} / \mathrm{ml}$ denatured salmon sperm DNA. For hybridization, denatured Ras and $\beta$ actin probes, radiolabeled with ${ }^{32} \mathrm{P}$ by the random primer method, were added to the hybridization mixture. After overnight incubation $\left(42^{\circ} \mathrm{C}\right)$, the filters were washed in $2 \times S S C$ ( $2 \times 5^{\circ}$, RT), $2 \times S S C$ and $1 \% \operatorname{SDS}\left(2 \times 15^{\prime}, 60^{\circ} \mathrm{C}\right)$ and 0.1 SSC (2x15', RT). Exposure of the filters was as described. 

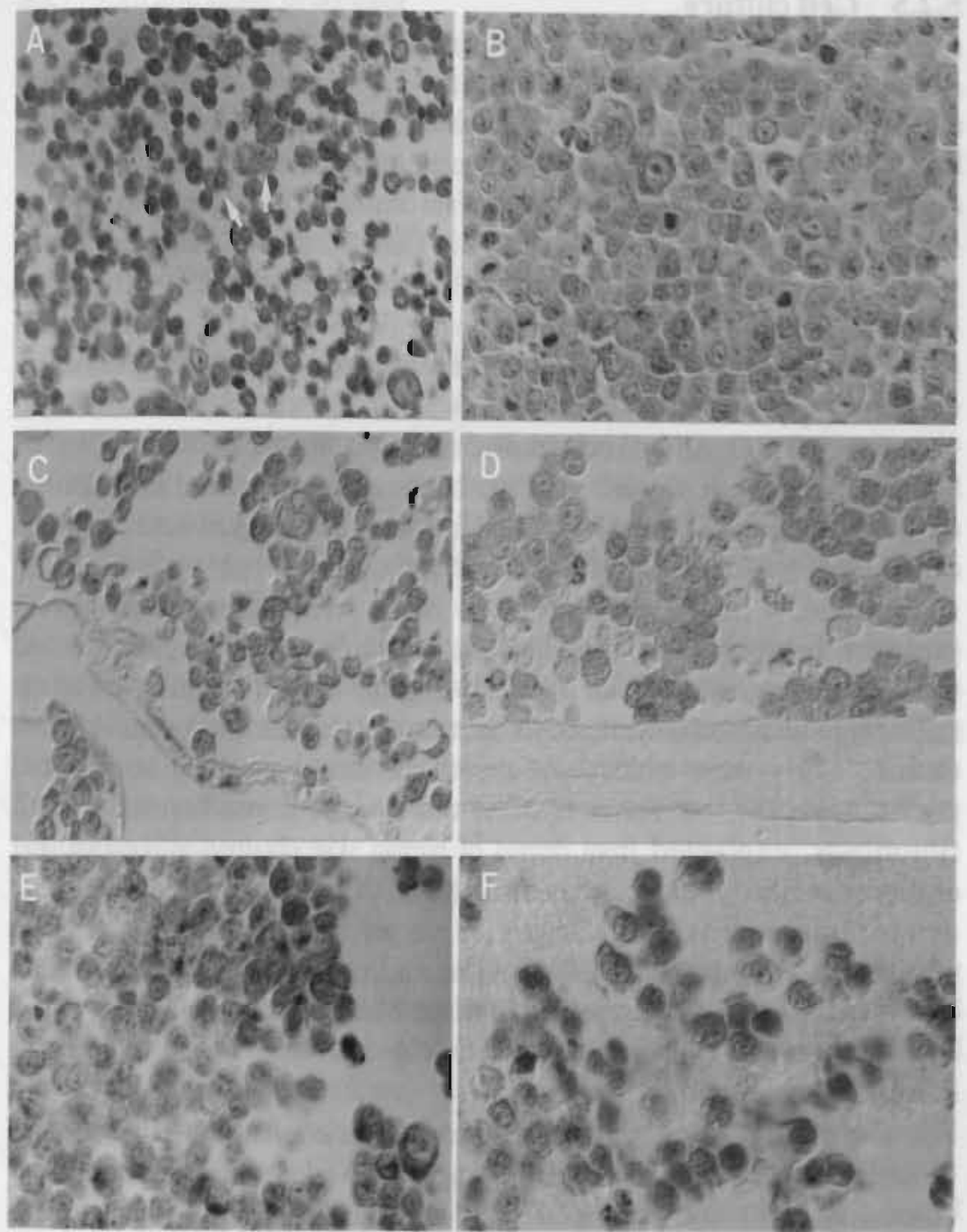

PLATE 3. Chromogranin A (CGA) immunoreactivity in NCl-H7!6, cells in various conditions. a. Standard culturing conditions (suspension/attached to type IV collagen coated surfaces). Rare cells show weak immunostaining (arrows). b. S.c. xenogratt. A poorly differentiated adenocarcinoma, in which a major proportion of cells shows CGA immunoreactivity. $c$-f. Increased CGA immunoreactivity in NCI-H7 $\mathrm{i} 6$ cells cultured on various extracellular matrix components (compare with a). c. Co-culture with fibroblasts. d. Cells grown on amnion membrane. e. Cells grown on surfaces coated with type IV collagen combined with heparan sulphate proteoglycan. f. Cells cultured in basement membrane Matrige1. (indirect immunoperoxidase with DAB, $\times 360$ ). 


\subsubsection{Cell culture}

Cells were cultured at $37^{\circ} \mathrm{C}$ in a humified atmosphere with $5 \% \mathrm{CO}_{2}$. The medium consisted of Dulbecco's modified Eagles' minimal essential medium (DMEM, Flow Laboratories, Zwanenburg, The Netherlands), supplemented with $10 \%$ fetal bovine serum (FBS, Boehringer, Mannheim, FRG). Caco-2 EJ6 cells were maintained in selective medium containing $800 \mu \mathrm{g} / \mathrm{ml}$ gentamycin. Induction of endocrine differentiation in $\mathrm{Caco}-2$ cells was attempted by supplementing the medium with glucose (final concentration $25 \mathrm{mM}$ ), sodium butyrate ( $\mathrm{NaBT}, 2 \mathrm{mM}$ ), dimethylsulfoxide (DMSO, $2 \% \mathrm{v} / \mathrm{v}$ ), or retinoic acid $(\mathrm{RA}, 35 \mu \mathrm{M})$. Cells were also cultured in serum free medium and in glucose free medium supplemented with $2.5 \mathrm{mM}$ inosine. (DMSO was obtained from Merck, Darmstadt, FRG; all other chemicals from Sigma, St. Louis, USA).

Furthermore, both Caco-2 and Caco-2 EJ6 cells were cultured in serumfree, defined medium (DMEM with $50 \mathrm{nM}$ hydrocortisone, $5 \mu \mathrm{g} / \mathrm{ml}$ insulin, $5 \mu \mathrm{g} / \mathrm{ml}$ transferrin, $5 \mathrm{nM}$ sodiumselenite, $100 \mu \mathrm{M}$ ethanolamine, $1 \mu \mathrm{M}$ putrescine, $4 \mu \mathrm{M}$ spermidine, $4 \mu \mathrm{M}$ spermine and $0.1 \%$ bovine serum albumin (BSA)) in the presence or absence of basic fibroblast growth factor (bFGF, $10 \mathrm{ng} / \mathrm{ml}$ ) and transforming growth factor $\beta$ (TGF $\beta, 1 \mathrm{ng} / \mathrm{ml}$ ). Several modifications of the culturing substrate were tested for their capacity to induce endocrine differentiation. Cells were cultured on amnion membranes, prepared as described previously (28), on feeder layers of two types of human fibroblasts (adult fibroblasts, explanted from dermis of human skin obtained at autopsy, and embryonal fibroblasts, purchased from the ATCC), and in two types of artificial extracellular matrix gels. Vitrogen 100 was purchased from the Collagen Corporation (Palo Alto, CA., USA), and basement membrane Matrigel from Collaborative Research Incorporated (Bedford, Mass., USA).

\subsubsection{In vivo studies}

For the xenografting experiments, immunedeficient female $\mathrm{CD}$ nu/nu mice (Charles River Wiga, Sulzfeld, FRG) aged 3-5 weeks, were inoculated subcutaneously (s.c.) with suspensions of $3-5 \times 10^{6}$ single tumor cells in phosphate buffered saline (PBS), obtained by gentle trypsinization $10.25 \%$ trypsine, DIFCO, Detroit, Mich., USA) at $37^{\circ} \mathrm{C}$.

To enhance the take rate, s.c. injection of single tumor cell suspensions in soluble Vitrogen 100 , or s.c. implantation of Vitrogen 100 gels containing $0.5 \times 10^{6}$ tumor cells cultured for 5 days (12) were attempted. Furthermore, animals were injected intraperitoneally every fifth day with $0.5 \mathrm{mg}$ of polyclonal antibody against asialo GMI ( $\alpha$ ASGMl, Wako Chemicals GmbH, Neuss, FRG), to eliminate natural killer (NK) cell activity (Table 1). 


\subsubsection{Cell and tissue processing}

Cells were harvested by gentle scraping. After washing twice in icecold PBS, cells were immersed $\left(3 \mathrm{hrs}, 4^{\circ} \mathrm{C}\right)$ in fixative containing ethanol $(100 \%)$, formalin (36\%) and glacial acetic acid $(97 \%)(15: 14: 1 \mathrm{v} / \mathrm{v})$ or in ethanol $70 \%$. Celis were resuspended in $4 \%$ agarose gel prior to routine tissue processing and paraffin embedding. Cells grown in Vitrogen 100 or basement membrane Matrigel and nude mouse xenografts were fixed and processed similarly. Xenografts were additionally snap frozen in liquid isopentane cooled to $=70^{\circ} \mathrm{C}$.

\subsubsection{Histochemistry and immunohistochemistry}

Paraffin sections $(4 \mu \mathrm{m})$ were screened for endocrine differentiation by combined histochemical staining for argyrophilia (Grimelius technique) and immunohistochemical staining with a monoclonal antibody against human chromogranin A (LK2H10, Hybritech, San Diego, CA., USA). For the latter, a standard indirect peroxidase labeled antibody technique was applied as was previously reported (29).

Phenotypical characterization of xenografts of Caco-2 and Caco-2 EJ6 was designed to identify the various intestinal epithelial cell lineages and to establish the neurohormonal profile of the endocrine lineage. The histochemical staining methods and the applied antibodies for immunohistochemistry are listed in Table 2. Immunohistochemical staining results were evaluated with appropriate positive and negative controls.

\subsubsection{Electron microscopy}

Tissues were fixed for 2 hours in $2.5 \%$ buffered glutaraldehyde, postfixed during 1 hour in $1.0 \%$ osmiumtetroxide (both in $0.1 \mathrm{M}$ phosphate buffer), dehydrated in graded ethanol series and embedded in Epon. Ultrathin sections were stained with uranyl acetate and lead citrate.

\subsubsection{Receptor assay}

The presence of somatostatin receptors was determined on cultured Caco-2 and Caco-2 EJ6 cells. For this purpose, ${ }^{125}$ l labeled octreotide (a long acting somatostatin analogue), with a tyrosine residue at position 3, was used ( ${ }^{125} \mathrm{I}-\mathrm{Tyr} 3-\mathrm{oc}-$ treotide, courtesy of Prof.dr. S.W.J. Lamberts, Dept. of Internal Medicine, Erasmus University, Rotterdam). Briefly, $5 \times 10^{5}$ tumor cells were seeded in a 6-well tissue culture dish and cultured for 3 days under standard conditions. After washing in PBS, the cells were incubated (2hrs., RT) with $400 \mu \mathrm{l}$ of receptor stabilizing buffer (170 mM Tris, $5 \mathrm{mM} \mathrm{MgCl}_{2}, 10 \mu \mathrm{g} / \mathrm{ml}$ bacitracin, $1 \%$ $\mathrm{BSA}, \mathrm{pH}$ 7.4) containing $1 \mathrm{nM}$ radiolabeled ligand with or without a 5000 -fold excess of unlabeled competitor (somatostatin-14). After washing steps (2x receptor stabilizing buffer, $1 \times$ PBS) the cells were trypsinized and again washed in PBS. Radioactivity was determined with a $\gamma$-counter. The receptor content 


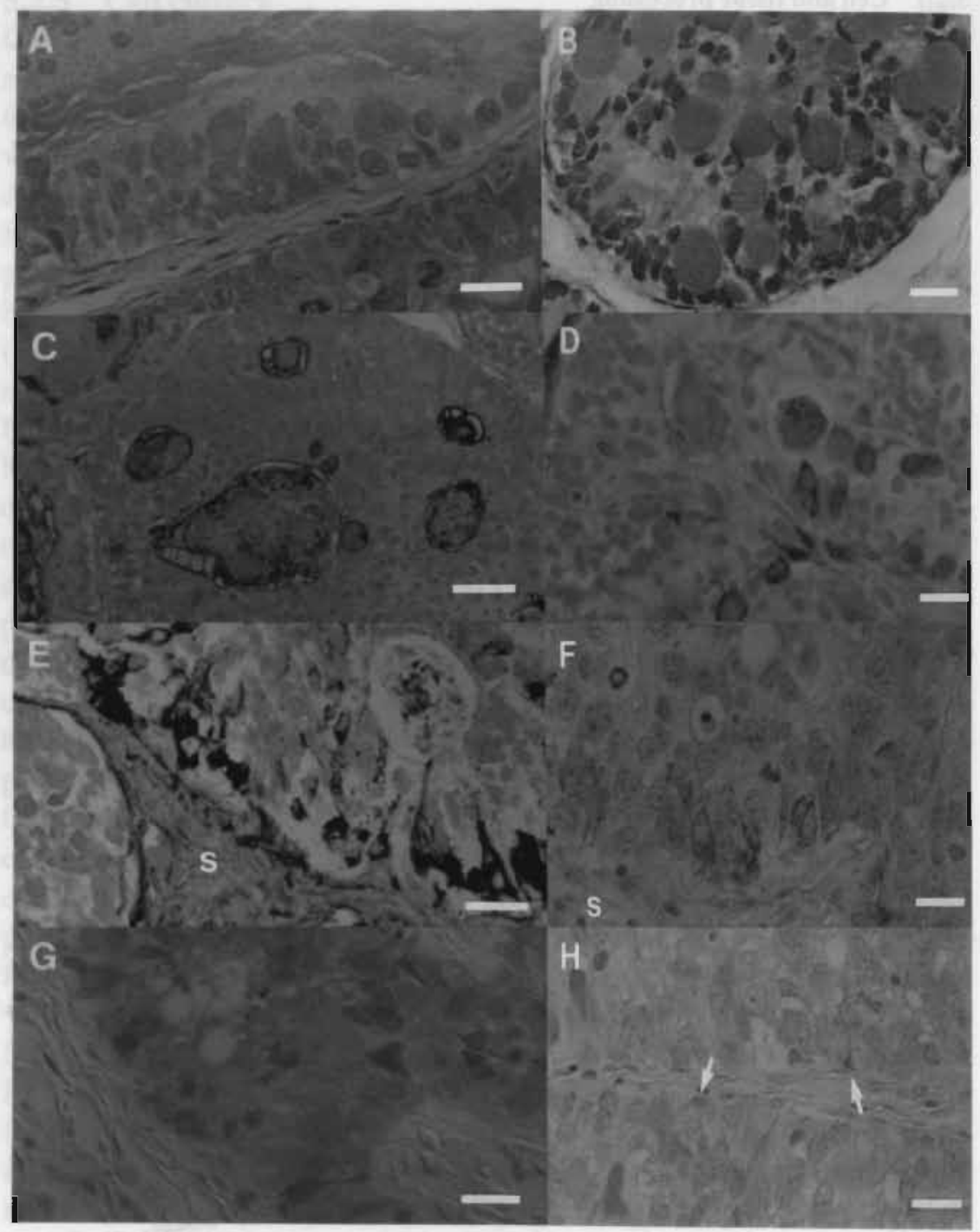

PLATE 4. Mucin production and endocrine differentiation in subcutaneous xenografts of both Caco-2 and Caco-2 EJ6.

a. Neutral mucopolysaccharides (PAS after diastase pretreatment)

b. Acid mucopolysaccharides (Alcian Blue, pH 2.4)

c. Sulfomucins (black) and sialomucins (blue) (HID-AB)

d. Goblet cell mucin glycoproteins (Parlam 3/9)

e. and $\mathbf{f}$. Endocrine cells peripheraliy in tumor lobules, in contact with stroma (s) (Grimelius

(e) and chromogranin $\mathrm{A}$ ( (i))

g. Neuron specific enolase

h. Focal immunoreactivity for somatostatin (arrows). (c: bar $=56 \mu \mathrm{m}$, all other bars $=28 \mu \mathrm{m}$ ) 
TABLE 2. Applied Staining Techniques

\section{Histochemistry}

Grimelius, Periodic-acid Schiff (PAS, with/without diastase pretreatment), Alcian Blue ( $\mathrm{pH} 2.4$ ), High-Iron-Diamine Alcian Blue (HID-AB)

Applied Antibodies (nature, source, type, dilution)

\section{Intestinal Differentiation Markers}

\begin{tabular}{|c|c|c|}
\hline \multirow[t]{2}{*}{-Enterocytes } & Sucrase-Isomaltase* & HBB $2 / 614 / 88-m c-1: 16000$ \\
\hline & Secretory Component & DAKO-pc-1:1000 \\
\hline -Goblet cells & Mucin (Parlam 3/9, 13) & own lab-mc-1:1000/2000 \\
\hline \multirow{6}{*}{-Endocrine celis } & Chromogranin A & Hybritech-mc-1:12500 \\
\hline & Chromogranin A/B & Milab-pc-1:2560 \\
\hline & Synaptophysin & Progen-mc-1:500 \\
\hline & NSE & DAKO-pc-1:1000 \\
\hline & Leu-7 & BD-mc-1:50 \\
\hline & EGC & Milab-pc-1:400 \\
\hline Paneth cells & Lysozyme & DAKO-pc-1:2500 \\
\hline -General markeт & CEA (Parlam 4) & own lab-mc-1:1000 \\
\hline
\end{tabular}

\section{Hormone Profile}

$\begin{array}{lll}\text {-Gastrointestinal-Colon } & \text { Serotonin }(5-\mathrm{HT}) & \text { own lab-pc-1:2000 } \\ & \text { Somatostatin } & \text { own lab-pc-1:1500 } \\ & \text { Glicentin } & \text { ED-pc-1:200 } \\ & \text { Substance P } & \text { Milab-pc-1:600 } \\ & \text { PYY } & \text { ED-pc-1:50 } \\ \text {-Gastrointestinal-Other } & \text { Gastrin } & \text { own lab-pc-1:250 } \\ & \text { Bombesin } & \text { ICN-pc-1:10000 } \\ & \text { Insulin } & \text { own lab-pc-1:1500 } \\ & \text { Glucagon } & \text { own lab-pc-1:500 } \\ & \text { Pancreas Polypeptide } & \text { own lab-pc-1:250 } \\ & \text { Neurotensin } & \text { Amersham-pc-1:2000 } \\ \text {-Extra-intestinal } & \text { BHCG } & \text { DAKO-pc- } 1: 2000 \\ & \alpha \text { HCG } & \text { own lab-pc-1:3000 } \\ & \text { ACTH } & \text { own lab-pc-1:100 } \\ & \text { Growth Homone } & \text { Progen-pc-1:8000 }\end{array}$

III. 2nd Antibodies

Swine-anti-rabbit

DAKO-1:150

Rabbit-anti-mouse

DAKO-1:200

*Generous gift of Dr. H.P. Hauri, Biozentrum der Universität, Basel, CH. 
was calculated from the amount of specifically bound radioligand, and expressed as the number of binding sites per cell.

\subsubsection{Quantification and statistical analysis of endocrine cells}

The number of endocrine cells in xenografts of Caco-2 and Caco-2 EJ6 was assessed by counting immmunoreactive tumor cells in $4 \mu \mathrm{m}$ thick sections of xenografts immunostained for chromogranin A. The density of endocrine cells was expressed per $\mathrm{mm}^{2}$ surface area of tumor. Using a gridded eyepiece, at a magification of $312.5 x, 30$ contiguous random fields of tumor were scored, representing a total surface area of $120 \mathrm{~mm}^{2}$ per tumor ( $\mathrm{n}=3$ for both cell lines). Scores were statistically compared by t-tests for independent groups with separate variances.

\subsection{RESULTS}

\subsubsection{Caco- 2 cells}

In vitro Caco-2 cells grew in monolayers of columnar cells with formation of domes (Fig. 1). In extracellular matrix gels glandular structures lined by flattened or cuboidal cells were formed (Fig. 2). In vitro, endocrine differentiation was not observed in Caco- 2 cells. None of the applied tissue culture modifications induced endocrine differentiation.
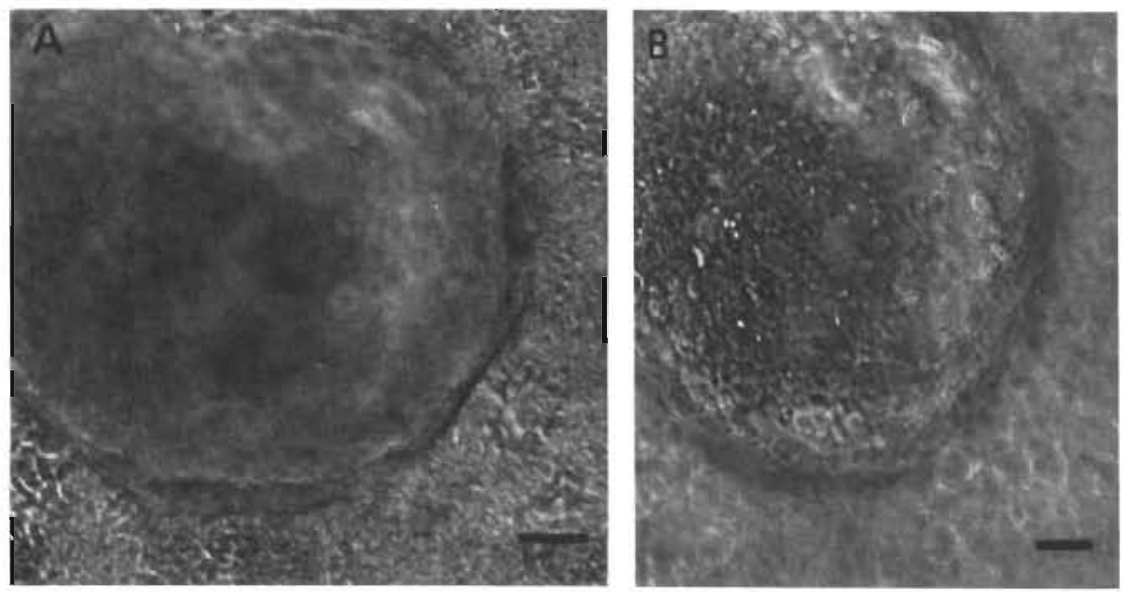

Figure 1. Phase-contrast micrograph of Caco-2 in vitro. Cells grow in confluent monolayers with formation of domes. a. Focussed on the monolayer. b. Focussed on the surface of the dome. Caco-2 EJ6 shows identical morphology in vitro. $($ bar $=120 \mu \mathrm{m})$ 

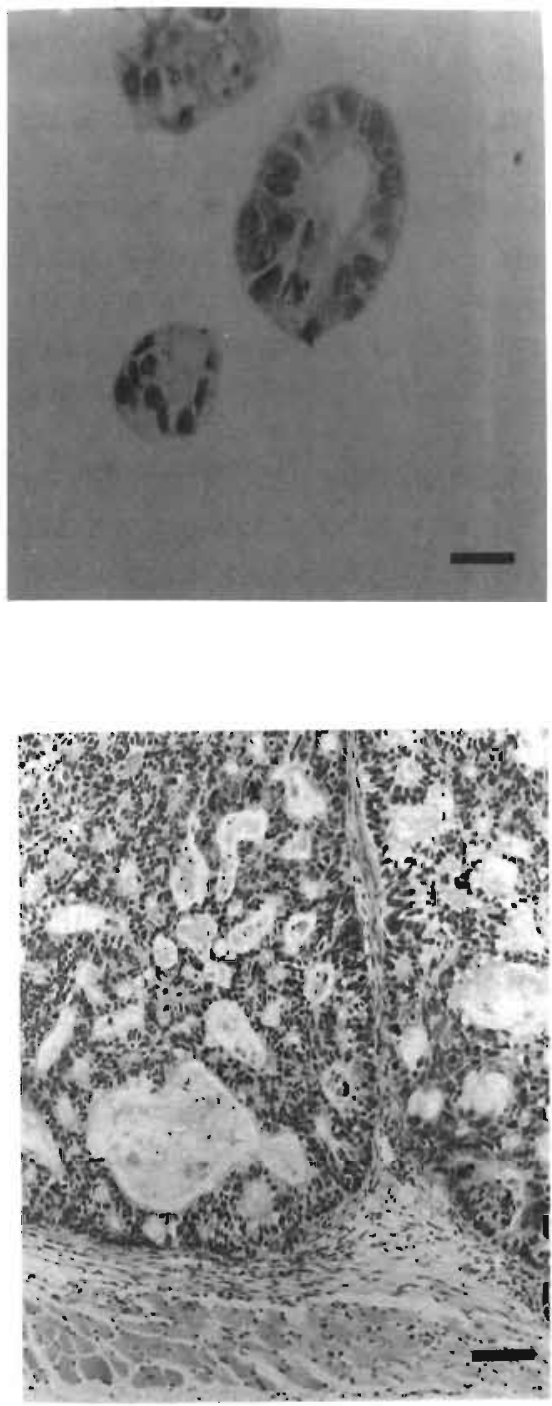

Figure 2. Three dimensional growth of Caco-2 EJ6 in basement membrane Matrigel. Cells are arranged in glandular formations lined by columnar cells. The same growth pattem was observed for Caco- 2 cells. $(\mathrm{H \& E}$, bar $=25 \mu \mathrm{m})$

Figure 3. Subcutaneous xenograft of Caco-2 EJ6 in nude mouse. The histological pattem is representative for both native and transfected cells, and shows a moderately well-differentiated adenocarcinoma with expansive growth, not invading neighbouring skeletal muscle. $(\mathrm{H} \& \mathrm{E}, \mathrm{bar}=100 \mu \mathrm{m})$

Under standard xenografting conditions Caco-2 cells did not yield tumors (Table 1). The tumor take rate could be increased by inoculating Caco- 2 cells in soluble Vitrogen 100 or as solid Vitrogen 100 collagen gels. Treatment of the animals with an antibody eliminating NK cell activity also improved the take rate. Xenografting of Caco-2 $\mathrm{CO} 1$ and $\mathrm{Caco}-2 \mathrm{CO} 2$ cells (containing the wild type Ras oncogene) and of Caco-2 D5 Neo cells (containing the empty plasmid) did not result in tumor growth under standard conditions. The tumors obtained after xenografting Caco-2 cells were moderately-well differentiated adenocarcinomas with expansive growth, without evidence of invasion (Fig. 3). 


\subsubsection{Caco-2 EJ6 cells}

Of the cell lines obtained after transfection of Caco-2 cells with point mutated c-Ha-Ras, Caco-2 EJ6 cells showed the highest level of Ras expression, and therefore these cells were further characterized. Southem blot analysis confirmed the integration of the point mutated Ras oncogene (Fig. 4a). By Northern blot analysis, expression of c-Ha-Ras mRNA was clearly increased compared with normal Caco-2 cells (Fig. 4b). Caco-2 EJ6 cells in vitro were morphologically identical to native $\mathrm{Caco}-2$ cells, and did not show endocrine differentiation either. As in Caco-2, the applied tissue culture variants did not induce endocrine differentiation in vitro.

In all xenografting conditions, except treatment with the $\alpha$ ASGMI antibody, the growth properties of Caco-2 EJ6 were more favorable (higher take rate or shorter latency) than of untransfected Caco-2 (Table I). Histologically, xenografts were identical to Caco-2 tumors, displaying the morphology of moderately well differentiated adenocarcinomas. Invasion was not observed. Cells representative of all intestinal cell lineages were present in xenografts from both the native and transfected cell line. Enterocytic differentiation in vivo was reflected in brushborder staining for sucrase-isomaltase and plasma membrane or cytoplasmic staining for secretory component (Fig. 5).

Both neutral (PAS staining after diastase pretreatment) and acid (Alcian Blue, pH 2.4) mucopolysaccharides could be demonstrated (Colorplate 4, page 104). The HID-AB stains showed a combination of sulfo- and sialomucins. Immunohistochemically, the tumors showed reactivity for various mucin-associated antibodies. Both expression of Parlam 3/9, identifying a protein moiety of glycoproteins present in normal goblet cells, and of Parlam 13, identifying a carbohydrate epitope in glycoproteins increasingly expressed in neoplastic colonic epithelium (30), were found (Colorplate 4).

Endocrine differentiation in Caco-2 EJ6 as well as Caco-2 xenografts was reflected in positive staining for several general neuroendocrine markers (Grimelius, chromogranin A, chromogranin A/B, synaptophysin, NSE)(Colorplate 4). Variable numbers of endocrine cells were found, scattered between the other cells. No significant increase in the number of endocrine cells was noted in Caco-2 EJ6. (Endocrine cell density $2.04 / \mathrm{mm}^{2}$ (s.e.m. 0.42) for Caco-2 EJ6 vs. $1.76 / \mathrm{mm}^{2}$ (s.e.m. 1.10) for Caco-2; $p=0.83$ ). Most endocrine cells were located peripherally in the tumor lobules, in direct contact with the extracellular matrix (Colorplate 4 and Fig. 6a). Ultrastructurally, a well formed basal lamina was present at the epithelial-stromal interface (Fig. 6b). Complete loss of endocrine differentiation occurred within three passages when Caco-2 EJ6 tumor xenografts were explanted in vitro. Endocrine differentiation was restored upon renewed xenografting of the cultured cells. This effect was consistently seen in both early and late in vitro passages of Caco-2 EJ6. Because of the difficulties in xenografting, these experiments were not performed for Caco-2. 
A

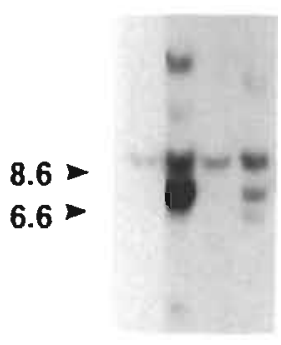

$\begin{array}{llll}1 & 2 & 3 & 4\end{array}$
B

\section{Ha-ras}

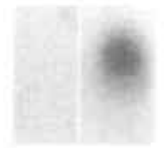

Actin

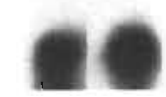

12

Figure 4. Integration and expression of $\mathrm{pSV}_{2}$ neoEJ in Caco-2

a. Southern blot. Lane 1. Caco-2, 2. Caco-2 EJ6, 3. Caco-2 EJ7, 4. Caco-2 EJ8. Chromosomal DNA was digested with $\mathrm{Bam} \mathrm{HI}$ and hybridized with the 3.0 Sac I fragment of the c-Ha-ras gene. The $6.6 \mathrm{~kb}$ Bam HI fragment of $\mathrm{pSV}_{2}$ neoEJ in Caco-2 EJ6 can be distinguished from the endogenous $8.6 \mathrm{~kb}$ Bam HI fragment of Caco-2. b. Northem blot. Lane 1. Caco-2, 2. Caco-2 EJ6.
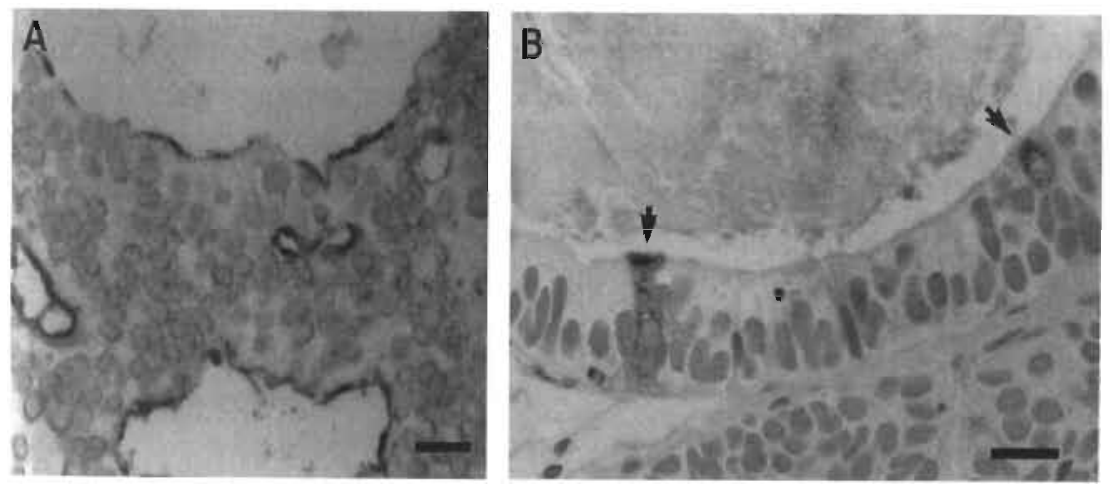

Figure 5. Enterocytic differentiation in vivo.

a. Frozen section of Caco-2 EJ6 xenograft showing apical luminal staining for the brushborder associated hydrolase sucrase-isomaltase.

b. Caco-2 xenograft with focal cytoplasmic and apical staining of columnar cells for secretory component (arrows). (indirect immunoperoxidases with DAB, bars $=25 \mu \mathrm{m}$ )

The neurohormonal profile of the endocrine cells in Caco-2 EJ6 and Caco-2 was restricted to somatostatin (Colorplate 4) and PYY, which both occur in normal colonic enteroendocrine cells $(31,32)$. Other colorectal endocrine secretory 

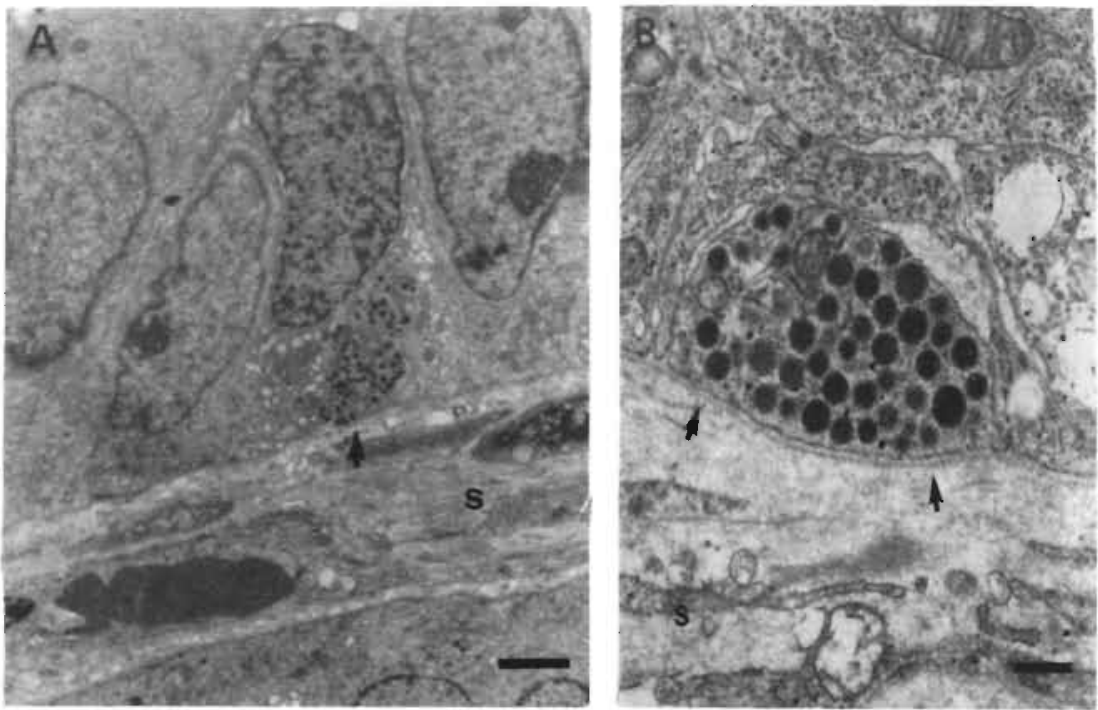

Figure 6. Ultrastructural morphology of Caco-2 EJ6 xenograft.

a. Endocrine cell containing neurosecretory granules (arrow) in contact with extracellular matrix $(\mathrm{s})$. $($ bar $=2.3 \mu \mathrm{m})$

b. Well-developed basal lamina (arrows) at the interface of stroma (s) and tumor cells, of which one contains dense core granules. (bar $=490 \mathrm{~nm}$ )

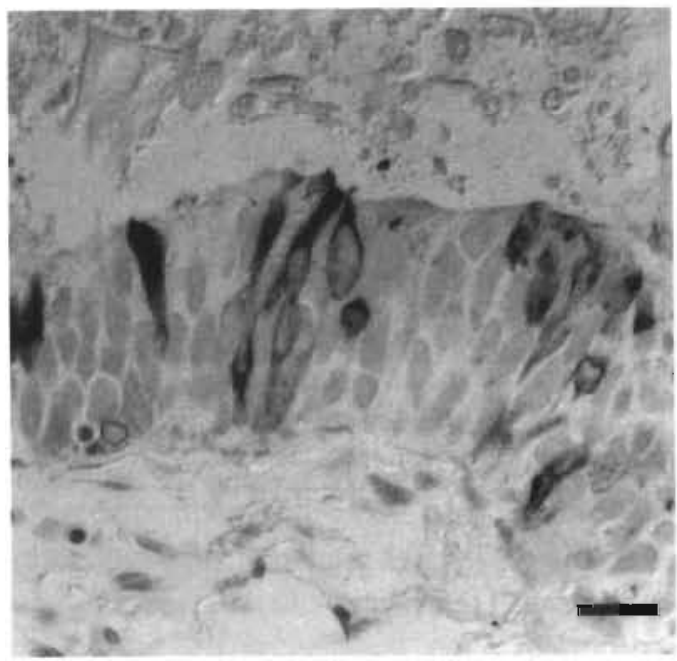

Figure 7. Cluster of Caco-2 cells with Paneth cell differentiation. (Lysozyme, bar $=25 \mu \mathrm{m}$ ) 


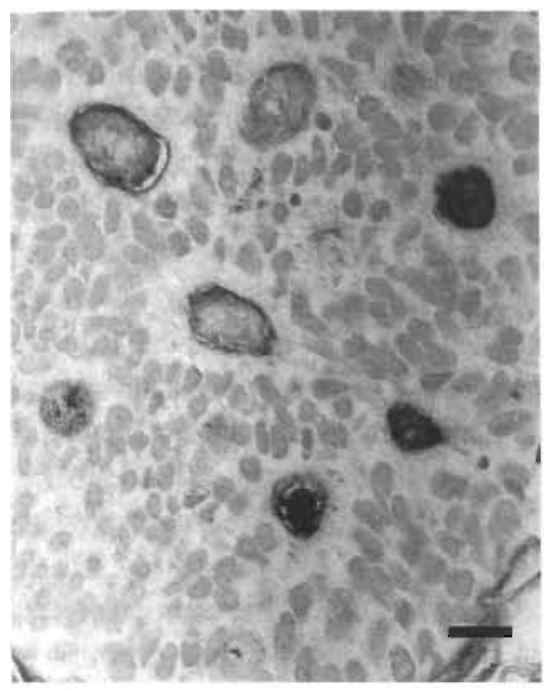

Figure 8. Intraluminal staining for CEA in a xenograft of Caco-2. (Parlam 4, bar $=25 \mu \mathrm{m})$

products (5-HT, glicentin, substance-P) were not identified. Focal expression of $\alpha H C G$ was found. Neither hormone production indigenous to other gastrointestinal sites (gastrin, bombesin, neurotensin, glucagon, insulin, pancreatic polypeptide), nor ectopic hormone production (ACTH, growth hormone) were found. Both Caco-2 and Caco-2 EJ6 in vitro demonstrated specific binding of the long-acting somatostatin analogue octreotide, with approximately 1900 and 800 binding sites per cell, respectively.

In addition to expression of markers for the three normal colorectal cell lineages, Paneth cell differentiation (lysozyme) (Fig. 7) and CEA production (Parlam 4)(33) (Fig. 8) were found.

\subsection{DISCUSSION}

The colon adenocarcinoma cell line Caco-2 in vitro forms monolayers of polarized enterocyte-like cells with tight junctions, well developed brushborder-membranes with associated hydrolases (34), and domes (35). The cell line has been frequently applied as a model to explore intestinal physiology and pathology, e.g. secretory processes (36); uptake and transport of electrolytes (37), nutrients (38-43) and drugs (44); activity, transport and organization of small and large intestinal enzymes (45-48); and intestinal infections (49-51). Under standard conditions in vitro, we did not find endocrine differentiation in Caco- 2 cells. However, in xenografts, which only could be attained by inoculating tumor cells in collagen gel or by suppressing NK cell activity in recipient 
animals, large numbers of endocrine cells could be demonstated. To our knowledge, endocrine differentiation has not been previously recorded in Caco- 2 cells. In view of the difficulty encountered in obtaining Caco-2 xenografts, we decided to transfect Caco-2 cells with a point mutated c-Ha-Ras gene, because of the reported association between overexpression of the point mutated c-Ha-Ras gene and tumor progression (15-17). Furthermore, these experiments would allow us to test wether or not overexpression of a point mutated Ras gene might induce or enhance endocrine differentiation. The latter question derived from experiments by Nakagawa et al. (18) and Mabry et al. (19), who demonstrated enhanced endocrine differentiation in medullary thyroid carcinoma cells and in small cell lung cancer cells respectively after transfection with v-Ha-Ras. After transfection and selection a cell line was obtained which showed overexpression of the c-Ha-Ras oncogene at the mRNA level: Caco-2EJ6. This cell line showed improved growth in vivo: co-injection of extracellular matrix components was not necessary and the latency period was considerably shorter than that of Caco- 2 cells.

We consider the improved take rate to be a result of the overexpression of the point mutated $\mathrm{Ha}-\mathrm{Ras}$ oncogene and not the result of the transfection procedure, because xenografting of cells transfected with the wild type oncogene or the empty plasmid did not result in tumor formation under standard conditions.

In xenografts of Caco-2 and Caco-2 EJ6 endocrine differentiation occurred to a similar extent. Evidently, the potential for endocrine differentiation was not enhanced by overexpression of the $\mathrm{c}-\mathrm{Ha}$-ras oncogene. This finding supports an earlier report indicating that there is no correlation between increased Ras oncogene expression and endocrine differentiation in colonic neoplasms (52). The hormone profile in both cell lines was identical and corresponded with hormone expression of normal colonic endocrine cells. In both cell lines endocrine cells produced immunohistochemically detectable somatostatin and specific somatostatin binding sites were found. Inhibition of growth of a colorectal adenocarcinoma cell line by somatostatin has been reported (53). This makes Caco-2 and Caco-2 EJ6 cells of potential interest to study autocrine or paracrine regulation of colorectal tumor growth.

On the basis of our observations we hypothesize that in Caco-2 and Caco- 2 EJ6 cells, stromal factors in xenografts induce the endocrine phenotype, as has been observed for HRA-19 and NCI-H716 cells. Circumstantial evidence in favor of this hypothesis can be summarized as follows. Firstly, endocrine cells were found preferentially at the periphery of tumor lobules, apposed to the extracellular matrix, with a well developed basal lamina at the interface. Secondly, in vitro cell cultures of Caco-EJ6 xenografts indicate that endocrine differentiation in vivo is most likely a matter of differentiation induction and not of selection, because endocrine cells rapidly disappeared in vitro but reappeared when cells were again xenografted in nude mice. However, it is unclear which stromal 
components are involved. In preliminary experiments we were unable to induce endocrine differentiation in vitro by specific extracellular matrix components, which have been shown to enhance endocrine differentiation in vitro in NCI$\mathrm{H} 716$ cells. The ability to induce endocrine differentiation in vitro therefore might depend on the level of differentiation of the cell line under investigation, because Caco- 2 cells in this respect resemble HRA-19 cells, which also display a moderately well differentiated phenotype and do not show endocrine features in vitro either.

In conclusion, we have shown that endocrine differentiation occurs in xenografts of Caco-2 cells. Endocrine differentiation is not enhanced by overexpression of the c-Ha-Ras oncogene. Growth properties in vivo, however, are improved by overexpression of a (transfected) c-Ha-Ras oncogene. The obtained cell line, Caco-2 EJ6, is a useful addition to the available colorectal cancer cell lines in which endocrine differentiation can be induced in vivo and/or in vitro. 


\subsection{REFERENCES}

1. Obemdorfer S. Über die "kleinen Dünndarmcarcinome". Verh Dtsch Ges Path 1907;11:113-116.

2. Damjanov I, Amenta PS, Bosman FT. Undifferentiated carcinoma of the colon containing exocrine, neuroendocrine and squamous cells. Virchows Arch A 1983;401:57-66.

3. Redman BG, Pazdur R. Colonic small cell undifferentiated carcinoma: a distinct pathological diagnosis with therapeutic implications. Am J Gastroenterol 1987;82:382-385.

4. Bosman FT, De Bruïne A. Endocrine cells in non-endocrine tumors of the gut and pancreas. In: Dayal Y ed, Endocrine pathology of the gut and pancreas, CRC Press, Boca Raton Ann Arbor Boston, 1991, pp.319-338.

5. Ho SB, Itzkowitz SH, Friera AM, Jiang S-H, Kim YS. Cell lineage markers in premalignant and malignant colonic mucosa. Gastroenterology 1989;97:392-404.

6. Arends JW, Wiggers T, Verstijnen C, Bosman FT. The occurrence and clinicopathological significance of serotonin immunoreactive cells in large bowel carcinoma. J Pathol 1986;149:97-102.

7. Jansson D, Gould VE, Gooch GT, Rittenhouse HG, Sik Shin S, Manderino GL, Tomita JT, Staren ED. Immunohistochemical analysis of colon carcinomas applying exocrine and neuroendocrine markers. APMIS 1988;96:1129-1139.

8. Johnson LR. Regulation of gastrointestinal mucosal growth. Physiol Rev 1988;68:456502.

9. Hoosein NM, Kiener PA, Curry RC, Brattain MG. Evidence for autocrine growth stimulation of cultured colon tumor cells by a gastrin/cholecystokinin-like peptide. Exp Cell Res 1990;186:15-21.

10. Kirkland SC. Endocrine differentiation by a human rectal adenocarcinoma cell line (HRA-19). Differentiation 1986;33:148-155.

11. De Bruine AP, Dinjens WNM, Pijls MMJ, Van der Linden EPM, Rousch MJM, Moerkerk PT, De Goeij AFPM, Bosman FT. NCI-H716 cells as a model for endocrine differentiation in colorectal cancer. Virchows Arch B Cell Pathol 1992;62:311-320.

12. Del Buono R, Pignatelli $M$, Hall PA. Control of differentiation in a rectal adenocarcinoma cell line: the role of diffusable and cell-associated factors. J Pathol 1991;164:5966.

13. De Brü̈ne AP, Dinjens WNM, Van der Linden EPM, Pijls MMJ, Moerkerk PT, Bosman FT. Extracellular matrix components induce endocrine differentiation in vitro in $\mathrm{NCl}$ H716 cells. Am J Pathol 1993; 142:773-782.

14. Rousset M. The human colon carcinoma cell lines HT-29 and Caco2: two in vitro models for the study of intestinal differentiation. Biochimie 1986;68:1035-1040.

15. Fearon ER, Vogelstein B. A genetic model for colorectal tumorigenesis. Cell 1990;61:759-767.

16. Muschel RJ, Williams JE, Lowy DR, Liotta LA. Harvey ras induction of metastatic potential depends upon oncogene activation and the type of recipient cell. Am J Pathol 1985; 121:1-8.

17. Lebeau J, Le Chalong C, Prosperi MT, Goubin G. Constitutive overexpression of a 89 $\mathrm{kDa}$ heat shock protein gene in the HBL 100 human mammary cell line converted to a tumorigenic phenotype by the E2/T24 Harvey-ras oncogene. Oncogene 1991;6:11251132. 
18. Nakagawa T, Mabry M, De Bustros A, Thle JN, Nelkin BD, Baylin SB. Introduction of $v$-Ha-ras oncogene induces differentiation of cultured human medullary thyroid carcinoma cells. Proc Nat Acad Sci USA 1987;84:5923-5927.

19. Mabry M, Nakagawa T, Baylin S, Pettengill O, Sorenson G, Nelkin B. Insertion of the $\mathrm{v}$-Ha-ras oncogene induces differentiation of calcitonin-producing human small cell lung cancer. J Clin Invest 1989;84:194-199.

20. Southem PJ, Berg P. Transformation of mammalian cells to antibiotic resistance with a bacterial gene under control of the SV40 early region promoter. J Mol Appl Genet 1982;1:327-341.

21. Capon DJ, Chen EY, Levinson AD, Seeburg PH, Goedel DV. Complete nucleotide sequence of the T24 human bladder carcinoma oncogene and its nomal homologue. Nature 1983;302:33-37.

22. Parada LF, Tabin CJ, Shih C, Weinberg RA. Human EJ bladder carcinoma oncogene is homologue of Harvey sarcoma virus ras. Gene 1982;297:474-478.

23. Sambrook J, Fritsch EF, Maniatis T. Molecular cloning, a laboratory manual. 2nd edition. Cold Spring Harbor Laboratory Press, New York, 1989.

24. Graham FL, Van der Eb AJ. A new technique for the assay of infectivity of human adenovirus 5 DNA. Virology 1973;52:456-467.

25. Chen C, Okayama H. High-efficiency transformation of mammalian cells by plasmid DNA. Mol Cell Biol 1987;7:2745-2752.

26. Feinberg AP, Vogelstein B. "A technique for radiolabeling DNA restriction endonuclease fragments to high specific activity". Addendum. Anal Biochem 1984;137:266267.

27. Moerkerk PT, Kessels HJ, Ten Kate J, De Goeij AFPM, Bosman FT. Southem and dot blot analysis of DNA from formalin-fixed, paraffin-embedded tissue samples from colonic carcinomas. Virchows Arch B Cell Pathol 1990;58:351-355.

28. Liotta LA, Lee CW, Morakis DJ. New method for preparing large surfaces of intact human basement membrane for tumor invasion studies. Cancer Lett 1980;11:141-152.

29. Dinjens WN, Ten Kate J, Kirch JA, Tanke HJ, Van der Linden EP, Van den Ingh HF, Van Steenbrugge GJ, Meera Khan P, Bosman FT. Adenosine deaminase complexing protein (ADCP) expression and metastatic potential in prostatic adenocarcinomas. $J$ Pathol 1990; 160: 195-201.

30. Verstijnen CPHJ, Arends JW, Moerkerk PTM, Pijls M, Kuypers-Engelen B, Bosman FT. Colonic epithelium reactive monoclonal antibodies - Identification and immunohistochemical localization of target epitopes. Histochemistry 1989;92:397-406.

31. Sjölund K, Sandén G, Håkanson R, Sundler F. Endocrine cells in human intestine: an immunocytochemical study. Gastroenterology 1983;85:1120-1130.

32. Sundler F, Böttcher G, Ekblad E, Håkanson R. The neuroendocrine system of the gut. Acta Oncologica 1989;28 Fasc 3:303-314.

33. Verstijnen CPHJ, Arends JW, Moerkerk PTM, Wamaar SO, Hilgers J, Bosman FT. CEA-specificity of CEA-reactive monoclonal antibodies. Immunochemical and immunocytochemical studies. Anticancer Res 1986;6:97-104.

34. Yoshioka M, Erickson RH, Matsumoto H, Gum E, Kim YS. Expression of dipeptidyl aminopeptidase IV during enterocytic differentiation of human colon cancer (Caco-2) cells. Int J Cancer 1991;47:916-921.

35. Ramond MJ, Martinot-Peignoux M, Erlinger S. Dome formation in the human colon carcinoma cell line Caco-2 in culture. Influence of ouabain and permeable supports. Biol Cell 1985;54:89-92. 
36. Chang EB, Bookstein C, Vaandrager A, De Jonge HR, Buse J, Musch MW. Cystic fibrosis transmembrane regulator $m R N A$ expression relative to ion-nutrient transport in spontaneously differentiating human intestinal Caco-2 epithelial cells. J Lab Clin Med 1991;118:377-381.

37. Watson AJ, Levine S, Donowitz M, Montrose MH. Kinetics and regulation of a polarized $\mathrm{Na}(+)-\mathrm{H}+$ exchanger from Caco-2 cells, a human intestinal cell line. Am J Physiol 1991;261(2Pt1):G229-G238.

38. Heyman M, Crain-Denoyelle AM, Nath SK, Desjeux JF. Quantification of protein transcytosis in the human colon carcinoma cell line $\mathrm{CaCo}-2$. J Cell Physiol $1990 ; 143: 391-395$.

39. Field FJ, Albright E, Mathur S. Inhibition of acylcoenzyme A:cholesterol acyltransferase activity by PD128042: effect on cholesterol metabolism and secretion in CaCo-2 cells. Lipids $1991 ; 26: 1-8$.

40. Mason JB, Shoda R, Haskell M, Selhub J, Rosenberg IH. Carrier affinity as a mechanism for the $\mathrm{pH}$-dependence of folate transport in the small intestine. Biochim Biophys Acta 1990; 1024:331-335.

41. Riley SA, Warhurst G, Crowe PT, Tumberg LA. Active hexose transport across cultured human Caco-2 cells: characterisation and influence of culture conditions. Biochim Biophys Acta 1991;1066:175-182.

42. Smith TK, Gibson CL, Howlin BJ, Pratt JM. Active transport of amino acids by ganıma-glutamyl transpeptidase through Caco-2 cell monolayers. Biochem Biophys Res Commun 1991;178:1028-1035.

43. Trotter PJ, Storch J. Fatty acid uptake and metabolism in a human intestinal cell line (Caco-2): comparison of apical and basolateral incubation. J Lipid Res 1991;32:293304.

44. Hilgers AR, Conradi RA, Burton PS. Caco-2 cell monolayers as a model for drug transport across the intestinal mucosa. Pharm Res 1990;7:902-910.

45. Jumarie C, Malo C. Caco- 2 cells cultured in serum-free medium as a model for the study of enterocytic differentiation in vitro. J Cell Physiol 1991;149:24-33.

46. Klumperman J, Boekestijn JC, Mulder AM, Fransen JA, Ginsel LA. Intracellular localization and endocytosis of brush border enzymes in the enterocyte-like cell line Caco-2. Eur J Cell Biol 1991;54:76-84.

47. Malagolini N, Dall'Olio F, Serafini-Cessi F. UDP-GalNac:NeuAc alpha 2,3 Gal beta-R (GalNAc to Gal) beta 1,4-N-acetylgalactosaminyltransferase responsible for the Sda specificity in human colon carcinoma $\mathrm{CaCo}-2$ cell line. Biochem Biophys Res Commun 1991;180:681-686.

48. Matter K, Stieger B, Klumperman J, Ginsel L, Hauri HP. Endocytosis, recycling, and lysusomal delivery of brush border hydrolases in cultured human intestinal epithelial cells (Caco-2). J Biol Chem 1990;265:3503-3512.

49. Darfeuille-Michaud A, Aubel D, Chauviere G, Rich C, Bourges M, Servin A, Joly B. Adhesion of enterotoxigenic Escherichia coli to the human colon carcinoma cell line Caco-2 in culture. Infect Immun 1990;58:893-902.

50. Rigothier MC, Coconnier MH, Servin AL, Gayral P. A new in vitro model of Entamoeba histolytica adhesion, using the human colon carcinoma cell line Caco-2: scanning electron microscopic study. Infect Immun 1991;59:4142-4146.

5I. Svensson L, Finlay BB, Bass D, Von Bonsdorff CH, Greenberg HB. Symmetric infection of rotavirus on polarized human intestinal epithelial (Caco-2) cells. J Virol 1991;65:4190-4197. 
52. Jansson DS, Radosevich JA, Camey WP, Rosen ST, Schlom J, Staren ED, Hyser MJ, Gould VE. An immunohistochemical analysis of ras oncogene expression in epithelial neoplasms of the colon. Cancer 1990;65:1329-1337.

53. Palmer Smith J, Solomon TE. Effects of gastrin, proglumide, and somatostatin on growth of human colon cancer. Gastroenterology 1988;95:1541-1548. 



\section{CHAPTER 6}

\section{ROLE OF GASTRIN,}

SEROTONIN, SOMATOSTATIN AND THEIR RECEPTORS IN GROWTH MODULATION OF COLON CANCER CELLS IN VITRO

A.F.P.M. de Goeij, A.P. de Bruïne, M.J.M. Rousch, and F.T.

Bosman. 


\subsection{INTRODUCTION}

In the gastrointestinal tract many endocrine cells occur, which produce and secrete a variety of neurohormonal substances. These substances, mainly small polypeptides but also amino acid derivatives such as biogenic amines, are regulators of gastrointestinal tract function (1). It has been demonstrated that several of these substances do not only influence the growth of normal mucosal epithelium, but also of cancer cells in the digestive tract (2). Evidence for the growth modulating effects of these neurohormonal factors has been obtained from clinical observations, animal model studies and in vitro experiments $(3,4)$. A stimulating effect on the growth of normal and malignant gastrointestinal epithelial cells has been reported for the peptides gastrin, bombesin/GRP, glucagon, and the biogenic amine serotonin (5-12). In contrast, the tetradecapeptide somatostatin was found to inhibit cellular proliferation (13).

Growth stimulating effects of gastrin on colon cancer cell lines in vitro have been well documented. In these studies the culture conditions and the parameters to measure growth varied widely. Using ${ }^{3} \mathrm{H}$-thymidine incorporation, gastrin appeared to stimulate growth of HT 29 cells (13) and of LoVo cells after synchronization (14). Using cell counting, Sirinek et al. (15) reported enhanced growth after exposure of HT 29 cells to gastrin in vitro. Imdahl et al. (11) found that synchronized LoVo cells are stimulated by gastrin, using a spectrofotometric method to measure the cell number. These authors also reported growth stimulation of SW 403 cells by gastrin. For LS $174 \mathrm{~T}$ cells no effect of gastrin on the proliferative activity in vitro was found by Imdahl et al. (11) and Watson et al. (16). Watson et al. (16) used the incorporation of ${ }^{75}$ Se-methionine as a parameter for growth, measuring the rate of protein synthesis which does not necessarily represent cell proliferation. Also for serotonin stimulating effects on the proliferative activity of normal and neoplastic cells have been reported $(8,17)$. Inhibitory effects might be expected from somatostatin, because it inhibits the release of growth stimulating hormones, impairs the action of growth factors and inhibits proliferation directly (18). Palmer Smith and Solomon (13) found a decreased growth rate in HT 29 cells after exposure to somatostatin, whereas Simopoulos et al. (12), Pelicci et al. (19), and Conteas and Majumdar (7) did not find an inhibiting effect of somatostatin on proliferation in vitro. In contrast, Moyer et al. (6) and Simopoulos et al. (12) reported stimulatory actions of somatostatin.

The effects of neurohormonal factors are mediated by specific membrane bound receptors. The presence of receptor is therefore a prerequisite for a cellular response to a signaling molecule (9). In several studies receptor expression on gastrointestinal cancer cells has been determined, but only rarely has this been correlated with the proliferative response to the ligand (3,20-22).

Evidently the studies on the growth modulating effects of neurohormones on 
colorectal cancer cells yield conflicting results. Also the presence of receptors for these neurohormones on colorectal cancer cells and their relation with proliferative activity is not well documented. Therefore, we determined gastrin, serotonin and somatostatin receptors on HT 29, LoVo, LS 174T, NCI-H716 and SW 403 cells. In parallel, the proliferative response to these factors was measured by incorporation of ${ }^{3} \mathrm{H}$-thymidine. For $\mathrm{NCI}-\mathrm{H} 716$ cells a detailed cell-kinetic analysis was performed by flow cytometry using receptor agonists and antagonists. Effects of neurohormones on proliferation were correlated with the receptor status of the cells.

\subsection{MATERIALS AND METHODS}

\subsubsection{Cell culture}

The human colon cancer cell lines HT 29, LoVo, LS 174T, SW 403 and $\mathrm{NCl}-\mathrm{H} 716$ and the human breast cancer cell line ZR-75 were obtained from the American Type Culture Collection (ATCC, Rockville, Maryland, USA). LoVo cells were cultured in HAM F12 medium, the other cells in Dulbecco's modified Eagles' minimal essential medium (DMEM) purchased from Flow Laboratories (Zwanenburg, The Netherlands). Cells were maintained in medium supplemented with 10\% fetal bovine serum (FBS, from Boehringer Mannheim, Germany) without antibiotics. As NCl-H716 cells grow in suspension they were harvested by centrifugation. The other cell lines were harvested by mild trypsinisation ( $0.25 \%$ trypsine, from DIFCO, Detroit, Mich., USA). After each passage cells were allowed to accomodate and adhere in 10\% FBS. Serum free medium contained hydrocortisone $(50 \mathrm{nmol} / \mathrm{l})$, transferrin $(5 \mu \mathrm{g} / \mathrm{ml})$, EGF $(1$ $\mu \mathrm{g} / \mathrm{ml})$, sodiumselenite $(5 \mathrm{nmol} / \mathrm{l})$, and HEPES $(15 \mathrm{mmol} / \mathrm{l})$.

\subsubsection{Hormones, antagonists, analogues}

Gastrin-17 (human Gastrin I), serotonin and somatostatin (human somatostatin14) were purchased from Sigma Chemical Co. (St. Louis, USA). The gastrin antagonist CAM 958 was a generous gift from Dr. J. Hughes, Parke Davis Research Unit, Cambridge, U.K. The serotonin antagonist methysergide was a kind gift from Dr. H. Struyker Boudier, Department of Pharmacology, University of Limburg, The Netherlands. The long-acting somatostatin analogue octreotide (Sandostatin, SMS 201-995) was purchased from Sandoz (Basel, CH).

\subsubsection{Receptor assays}

Receptors for gastrin, serotonin and somatostatin were determined by radioligand binding assay. For this purpose, gastrin-17 and Tyr-1-somatostatin-14 were labeled with carrier free $\mathrm{Na}^{125} \mathrm{I}$ (specific activity $2000 \mathrm{Ci} / \mathrm{mmol}$ ) using the Iodo-Gen method (Pierce Chemical Company, Rockford, Ill., USA), essentially 
according to Singh et al. (23). Free iodine was removed by elution of the reaction mixture over a C18 silicagel column (SEP-PAK ${ }^{\mathrm{R}}$ Cartridge, Millipore Corp., Milford, Mass., USA) with a 10-80\% methanol gradient in $1 \%$ trifluoroacetic acid. The labeling efficiency was $25-30 \%$ for both peptides. Serotonin receptors were quantitated with tritiated 5-hydroxytryptamine creatinine sulphate $\left({ }^{3} \mathrm{H}\right.$ serotonin, specific activity $12.3 \mathrm{Ci} / \mathrm{mmol}$ ). All isotopes were purchased from Amersham International, UK.

After harvesting, the cells were washed in PBS. Cells were collected by centrifugation, suspended in culture medium supplemented with $10 \%$ FBS and seeded at a concentration of $2 \times 10^{6}$ cells per well in six-well culture plates (Greiner, The Netherlands). After culturing for 18-24 hours, the supernatant was removed, 200 $\mu \mathrm{l}$ PBS was added to the wells and the cells were incubated $\left(2 \mathrm{~h}\right.$ at $\left.25^{\circ} \mathrm{C}\right)$ in triplicate with an equal volume of receptor stabilizing buffer $(25 \mathrm{mM}$ HEPES, $2.5 \mathrm{mM} \mathrm{MgCl}_{2}, 5 \mathrm{mM} \mathrm{KCl}, 137 \mathrm{mM} \mathrm{NaCl}, 0.7 \mathrm{mM} \mathrm{NaHPO}_{4}, 10 \mathrm{mM}$ glucose, $0.5 \%$ BSA, $0.1 \%$ soybean trypsin inhibitor and bacitracin $20 \mu \mathrm{g} / \mathrm{ml}, \mathrm{pH} 7.4$ ) containing $10 \mathrm{nM}$ radiolabeled ligand with or without a 1000 -fold excess of unlabeled ligand. After washing four times in this buffer at $4^{\circ} \mathrm{C}$ the cells were harvested after incubation with buffer containing $1 \%$ trypsin (15 min at room temperature). Radioactivity in this solution was determined with a gamma or beta counter. The receptor content was calculated from the amount of specifically bound radioligand, and expressed as the number of binding sites per cell. For NCI-H716 cells, the maximum number of binding sites $\left(B_{\max }\right)$ and the dissociation constant $\left(K_{d}\right)$ for the three neurohormones was determined by Scatchard plot analysis.

Competition experiments were performed at a fixed concentration of $5 \mathrm{nM}$ for radiolabeled gastrin and somatostatin and $10 \mathrm{nM}$ for serotonin. Increasing concentrations of unlabeled ligand or antagonist were used ranging from $5 \mathrm{nM}$ to $10 \mu \mathrm{M}$.

\subsubsection{Incorporation of ${ }^{3} \mathrm{H}$-thymidine}

Prior to the ${ }^{3} \mathrm{H}$-thymidine incorporation assay the tumor cells were grown in medium without the neurohormone during 16 to $24 \mathrm{~h}$. To determine the effects of gastrin, serotonin and somatostatin on cell proliferation, $50 \times 10^{3}$ tumor cells/well were seeded in microtiter plates in $100 \mu 1$ HAM F12 (LoVo cells) or DMEM (other cell lines), supplemented with 0 or $10 \%$ complete FBS or $1 \%$ dialyzed FBS, and were incubated during 48 or 72 hours with 0,1 or $10 \mathrm{nM}$ of the neurohormone. The culture medium was not changed, but every 24 hours fresh hormone was added in $100 \mu \mathrm{l}$ culture medium with $0.1 \% \mathrm{BSA}$, the final $24 \mathrm{~h}$ including $12 \mu \mathrm{mol}$ [Methyl ${ }^{3} \mathrm{H}$ ]-Thymidine (specific activity $80 \mathrm{Ci} / \mathrm{mmol}$ ), obtained from Amersham International, UK. Cells were harvested by aspiration or trypsinization using a Titertek Cell Harvester and collected on filters (cat. no 11731, obtained from Skatron AS, Norway). The filters were washed with ice 
cold medium and dried $\left(2 \mathrm{~h}, 80^{\circ} \mathrm{C}\right)$. Radioactivity was measured with a beta counter. As a positive control for the proliferation assay the incorporation of ${ }^{3} \mathrm{H}$-thymidine in ZR-75 breast cancer cells was determined in the presence of 0 , 1 and $5 \mathrm{nM}$ estradiol.

\subsubsection{Synchronization of cells}

The cell lines HT 29, LoVo and LS 174T were synchronized in the G1 phase using a block with excess thymidine. To this end $5 \times 10^{5}$ cells $/ \mathrm{ml}$ were suspended in DMEM supplemented with $10 \%$ FBS and $3 \mathrm{mM}$ thymidine, and incubated overnight. After washing, the cells were exposed to a second thymidine block during 18 hours. After washing in DMEM the cells were harvested and the incubation with the hormone started 5, 10 and 25 hours after release of the thymidine block.

\subsubsection{Flow cytometric analysis}

NCI-H716 cells in standard culturing conditions usually contain about $30 \%$ non-viable cells, as revealed by trypan blue exclusion. The presence of these dead cells and debris disturbed the flow cytometric analysis. Therefore, prior to the onset of the experiments, it was essential to remove non-viable cells and debris by centrifugation of cells over a 45\% Percoll solution in PBS, resulting in $>95 \%$ of viable cells at the beginning of the incubation period. In all flow cytometry experiments, $\mathrm{NCI}-\mathrm{H} 716$ cells were cultured in the presence of $10 \%$ FBS. Cells were exposed to neurohormone or antagonist during 20 hours. The neurohormones and the somatostatin analogue octreotide were administered in concentrations between 1 and $10 \mathrm{nM}$. The antagonists CAM 958 and methysergide were given in a concentration up to $500 \mathrm{nM}$ and $10 \mu \mathrm{M}$ respectively. At the end of the incubation period, cells were pulse labeled with $10 \mu \mathrm{M}$ 5-bromo-2'deoxyuridine (BrdU, from Serva, Heidelberg, Germany) during 30 minutes. Cells were washed with PBS (3x) and refed with $5 \mathrm{ml}$ of their own culture supernatant. After a chase period of 4 hours, the cells were washed with PBS (2x) and fixed in $70 \%$ ethanol. Cells were stained in suspension by an indirect immunofluorescence method, using an anti-BrdU mouse-monoclonal antibody, after pretreatment with pepsin $(0.04 \%$ in $0.1 \mathrm{~N} \mathrm{HCl}, 30 \mathrm{~min}$ at room temperature), acid denaturation of DNA in $2 \mathrm{~N} \mathrm{HCl}\left(30 \mathrm{~min}\right.$ at $\left.37^{\circ} \mathrm{C}\right)$ and neutralization in sodiumtetraborate buffer (0.1 M, pH 8.5) according to Schutte et al. (24). The bound antibody was visualized with a rabbit anti-mouse $\operatorname{IgG}$ conjugated to fluorescein isothiocyanate (FITC) obtained from DAKO. DNA was stained with propidium iodide (PI, $15 \mathrm{~min}$ at room temperature).

Cell-kinetic analysis was done on a FACS IV flow cytometer (Beckton \& Dickinson, Sunnyvale, CA., USA), applying the method first described by Begg et al. (25) and modified by White et al. (26). DNA synthesis time (Ts) is calculated by the formula: $T s=t \times 0.5 /(R M-0.5\}$, in which $R M$ is the relative 
movement (the movement of S-phase cells relative to the positions of $\mathrm{G} 1$ and G2) and $t$ is the sampling time. With the labeling index (LI, the fraction of cells synthesizing DNA), the potential doubling time (Tpot, doubling time without taking cell loss into account) can be calculated from the equation Tpot $=$ $\lambda \times \mathrm{Ts} / \mathrm{LI}$. $\lambda$ is a correction factor for the nonlinear distribution of cells through the cell cycle, and is taken as a fixed value close to unity according to Begg et al. (25).

\subsubsection{Statistical analysis}

Data were analysed by Student t-tests, if the Fisher-Snedecor test was fulfilled. If this was not the case, a non parametric paired Wilcoxon test was performed.

\subsection{RESULTS}

\subsubsection{Receptor assays}

Neurohormonal effects on cell proliferation are to be transduced by specific membrane bound receptors. Therefore radioligand binding assays for gastrin, serotonin and somatostatin on intact colon cancer cells were performed and the results are shown in Table 1. Gastrin receptors were found on LS 174T, SW 403 and NCI-H7 16 cells, but not on HT 29 and LoVo cells. Serotonin receptors were abundantly present on SW 403 and NCI-H716 cells, but could not be demonstrated on HT 29, LoVo and LS $174 \mathrm{~T}$ cells. Somatostatin receptors were detected on the five colon cancer cell lines tested, with a relatively low number on LS $174 \mathrm{~T}$ and a high number on NCI-H716 cells. In NCI-H716 cells Scatchard analysis revealed high affinity type receptors for gastrin, serotonin and somatostatin as shown in Figure 1.

TABLE 1. Receptors for gastrin, serotonin and somatosiatin on colon cancer cell lines.

\begin{tabular}{llll}
\hline Cell line & Gastrin receptor & Serotonin receptor & Somatostatin receptor \\
\hline HT 29 & 0 & 0 & 5900 \\
LoVo & 0 & 0 & 2500 \\
LS 174T & 2250 & 0 & 500 \\
SW 403 & 4700 & 230000 & 2750 \\
NCI-H716 & 5250 & 52000 & 21000 \\
\hline
\end{tabular}

Results are expressed as receptor sites per cell, and represent the mean of two (HT 29, LoVo, LS 174T and SW 403) and five (NCI-H716) experiments. The standard error of the mean for the receptor assays is $10-30 \%$. 


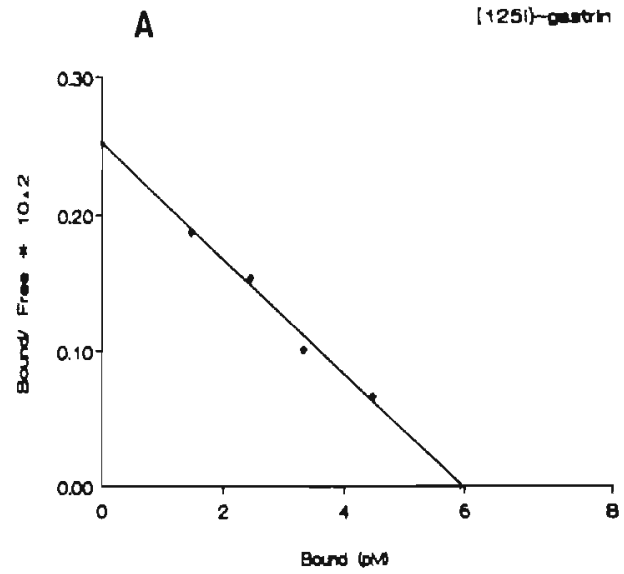

B

[3-1)-Serotont

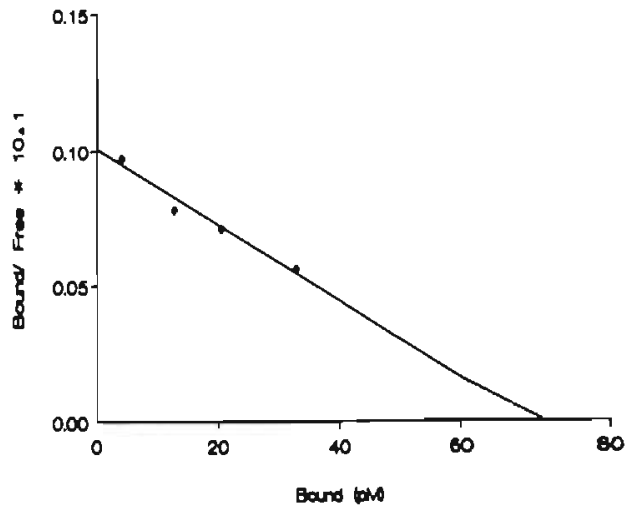

C

|12s\}-SS14

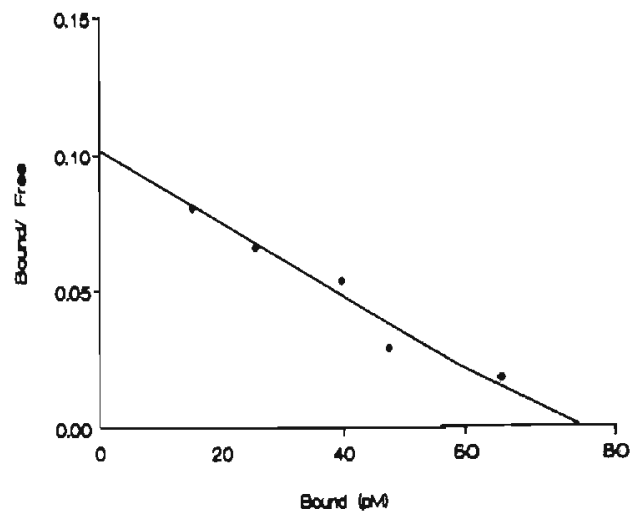

Figure 1. Representative examples of Scatchard plot analysis for binding of ${ }^{125} \mathrm{I}$-Gastrin, ${ }^{3} \mathrm{H}$-Serotonir and ${ }^{125}$ I-Somatostatin to NCI-H716 colon cancer cells; a. Gastrin. Bmax = 4200 sites/cell, $\mathrm{Kd}=2.4 \mathrm{nM}$; b. Serotonin. $B \max =46000$ sites/cell, $\mathrm{Kd}=7.3 \mathrm{nM}$; c. Somatostatin. $B \max =18000$ sites/cell, $\mathrm{Kd}=0.73 \mathrm{nM}$. 

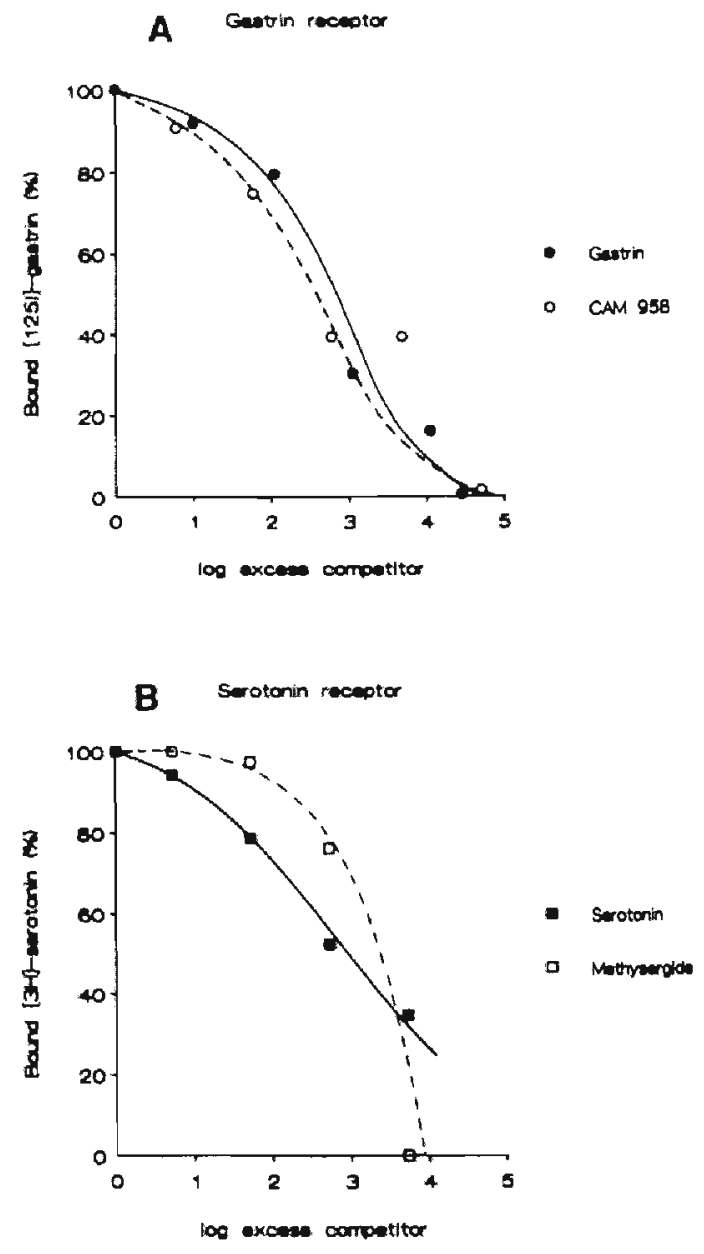

Figure 2. Competition of agonists and antagonists for gastrin, serotonin and somatostatin receptor binding sites on NCI-H716 colon cancer cells. Specific binding of the radiolabeled ligand is plotted against the excess of the unlabeled competitor, presented on a log scale. Nonspecific binding was $40-$ $60 \%$ of the total binding; a. Gastrin receptor; binding of ${ }^{125} \mathrm{I}$-gastrin is competitively inhibited by unlabeled gastrin and CAM 958. The affinity of these ligands for the receptor sites does not differ significantly; b. Serotonin receptor; binding of ${ }^{3} \mathrm{H}$-serotonin is competitively inhibited by unlabeled serotonin and at higher concentrations also by methysergide. The binding affinity of methysergide is lower than of serotonin; $c$. Somatostatin receptor, binding of ${ }^{125} \mathrm{I}$ somatostatin is competitively inhibited by unlabeled somatostatin and its analogue octreotide. Octreotide binds with some higher affinity to the somatostatin receptors. 
To evaluate whether or not the selected (ant)agonists were able to bind to these receptor sites on NCI-H716 cells, competition experiments were performed. The results are presented in Figure $2 \mathrm{a}-\mathrm{c}$ and show that binding of gastrin, serotonin and somatostatin is competitively inhibited by the gastrin antagonist CAM 958, the serotonin antagonist methysergide, and the somatostatin analogue octreotide, respectively. The results of the competition experiments demonstrate that these (ant)agonists indeed interact specifically with the neurohormonal binding sites of the respective receptors. The binding affinity of CAM 958 and octreotide does not differ significantly from the neurohormones gastrin and somatostatin respectively. Methysergide has a much lower affinity for the serotonin receptor sites and displaces serotonin in the micromolar range.

\subsection{2 ${ }^{3} \mathrm{H}$-Thymidine assays}

Our experimental design to detect proliferative activity by measuring ${ }^{3} \mathrm{H}$-thymidine incorporation was validated by testing the response of ZR-75 breast carcinoma cells to the hormone estradiol. The results are presented in Figure 3a. Dose dependent stimulation of ${ }^{3} \mathrm{H}$-thymidine incorporation by estradiol was found in ZR-75 cells, growing in medium with dialyzed serum.

The effect of gastrin, serotonin and somatostatin on the proliferative activity of HT 29, LoVo, LS 174 T, NCl-H716 and SW 403 cells was evaluated by incubating the cells under a variety of conditions. Incorporation of ${ }^{3} \mathrm{H}$-thymidine in HT 29, LoVo, LS 174T and SW 403 colon cancer cells was not significantly changed by either of the three neurohormones. This was found in all experiments performed, including culturing in serum free medium, medium with $1 \%$ dialyzed serum, medium with 10\% complete serum, in the presence of 1 and 10 $\mathrm{nM}$ of the neurohormone, and incubation during 48 and 72 hours. Also, cell cycle synchronization of HT 29, LoVo and LS 174T cells by blocking with thymidine did not reveal a proliferative response to the neurohormones.

The incorporation of ${ }^{3} \mathrm{H}$-thymidine in DNA of NCI-H716 cells was not affected by gastrin, serotonin and somatostatin under standard culturing conditions (10\% complete serum). However, stimulation of growth by gastrin and serotonin was found under serum free conditions when the proliferative activity of the cells was strongly reduced. Figure $3 \mathrm{~b}$ summarizes the effects of gastrin and serotonin on the ${ }^{3} \mathrm{H}$-thymidine incorporation in NCI-H716 cells. In these conditions gastrin at a concentration of 1 and $10 \mathrm{nM}$ caused an increase of about $70 \%$ in ${ }^{3} \mathrm{H}$-thymidine incorporation. Serotonin at a concentration of $1 \mathrm{nM}$ raised the incorporation of ${ }^{3} \mathrm{H}$-thymidine about $35 \%$, whereas at $10 \mathrm{nM}$ no significant effect could be detected. Somatostatin at concentrations of 1 and $10 \mathrm{nM}$ did not have a significant effect (latter results not shown). 

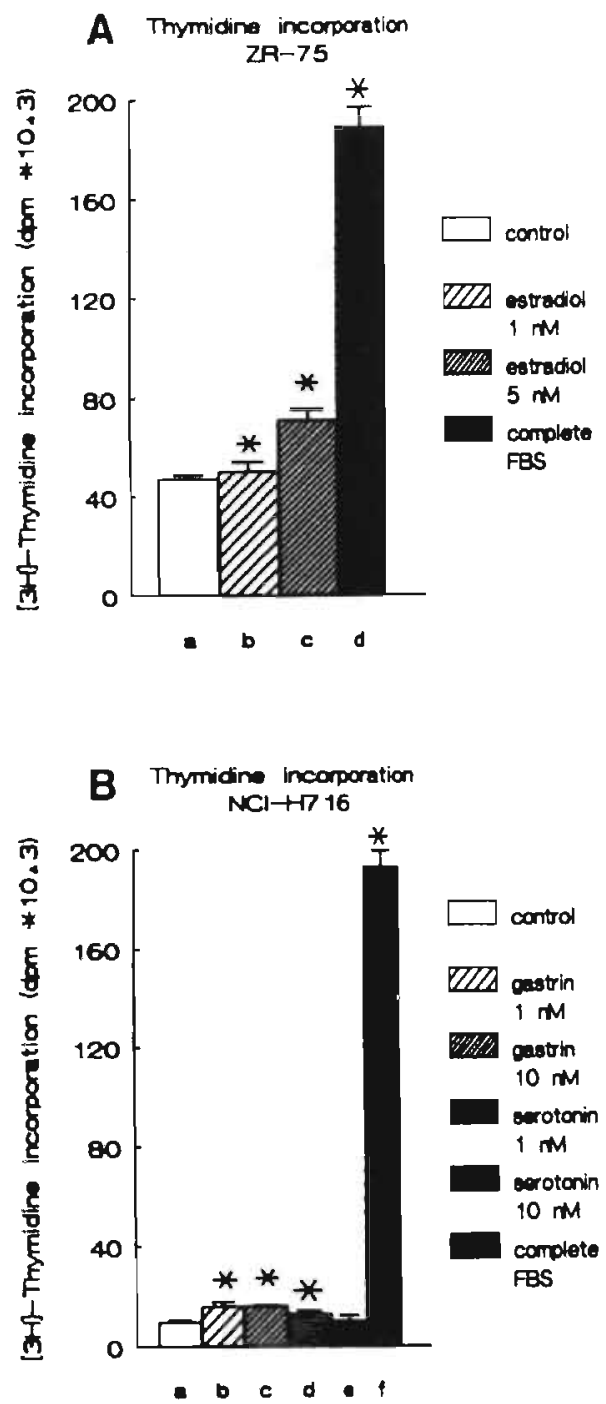

Figure 3. Hormonal effects on the proliferative activity of cancer cells in vitro as measured by incorporation of ${ }^{3} \mathrm{H}$-thymidine;

A. Stimulation of ${ }^{3} \mathrm{H}$-thymidine incorporation in ZR-75 breast cancer cells by the steroid hormone cstradiol. The incorporated radioactivity was determined after 24 hours of incubation in medium containing: a) 5\% dialyzed FBS; b) 5\% dialyzed FBS with $1 \mathrm{nM}$ estradiol added; c) $5 \%$ dialyzed FBS with $5 \mathrm{nM}$ estradiol added; d) $10 \%$ complete FBS.

B. Modulation of ${ }^{3} \mathrm{H}$-thymidine incorporation in NCI-H716 cells by gastrin and serotonin. The incorporated radioactivity was detennined after 48 hours of incubation in serumfree medium containing: a) no additions; b) $1 \mathrm{nM}$ gastrin; c) $10 \mathrm{nM}$ gastrin; d) $1 \mathrm{nM}$ serotonin; e) $10 \mathrm{nM}$ serotonin. The incorporated radioactivity in the presence of $10 \%$ complete FBS is presented in $\mathbf{f}$ ). 
TABLE 2. Distribution of NCI-H716 colon cancer cells over phases of the cell-cycle.

\begin{tabular}{llll}
\hline & $\% \mathrm{G} 0 / \mathrm{Gl}$ & $\% \mathrm{~S}$ & $\% \mathrm{G} 2 \mathrm{M}$ \\
\hline Gastrin & & & \\
-Control & $28 \pm 7$ & $39 \pm 10$ & $33 \pm 3$ \\
-Gastrin 5 nM & $31 \pm 9$ & $40 \pm 13$ & $29 \pm 3$ \\
-CAM 958 500 nM & $32 \pm 6$ & $38 \pm 9$ & $30 \pm 3$ \\
& & & \\
Serotonin & & & $36 \pm 7$ \\
-Control & $25 \pm 2$ & $39 \pm 9$ & $33 \pm 8$ \\
-Serotonin 10 nM & $25 \pm 2$ & $40 \pm 5$ & $33 \pm 7$ \\
-Methysergide 10 $\mathrm{MM}$ & $27 \pm 2$ & & \\
& & & $26 \pm 8$ \\
Somatostatin & & $51 \pm 10$ & $24 \pm 7$ \\
-Control & $23 \pm 5$ & $52 \pm 8$ & $27 \pm 8$ \\
-SS-14 5 nM & $24 \pm 8$ & $49 \pm 13$ & \\
-Octreotide 10 nM & $24 \pm 6$ & & \\
\hline
\end{tabular}

The percentages, as determined by flowcytometry, represent the mean \pm s.d. of five experiments. No significant differences are found between control cells and treated cells.

\subsubsection{Flow cytometric analysis}

Neurohormone-induced changes in cell kinetics of NCI-H716 cells were studied by two-parameter flow cytometry after BrdU-incorporation. The effect of neurohormones, the antagonists CAM 958 and methysergide and the agonist octreotide on the distribution of cells over the $\mathrm{G}_{0} / \mathrm{G}_{1}, S$ and $\mathrm{G}_{2} / \mathrm{M}$ phases of the cell cycle was determined. The results are presented in Table 2 and show that the percentage of cells in $\mathrm{G}_{0} / \mathrm{G}_{1}, S$ or $\mathrm{G}_{2} / \mathrm{M}$ did not change significantly by addition of neurohormones, their agonists or antagonists, indicating that no blocks occur in these phases. Cell kinetics were further analyzed by determination of the labeling index $\mathrm{LI}$, representing the fraction of cells synthesizing DNA, the duration of the S-phase Ts, and the potential doubling time of the cell population Tpot. LI was not affected significantly in the presence of neurohormones, their antagonists or agonists. However, Ts, and consequently Tpot, were clearly increased by addition of CAM 958 and octreotide, as shown in Figure 4. The effect of serotonin was borderline significant. Gastrin, methysergide, and somatostatin did not influence cell kinetic parameters significantly. 

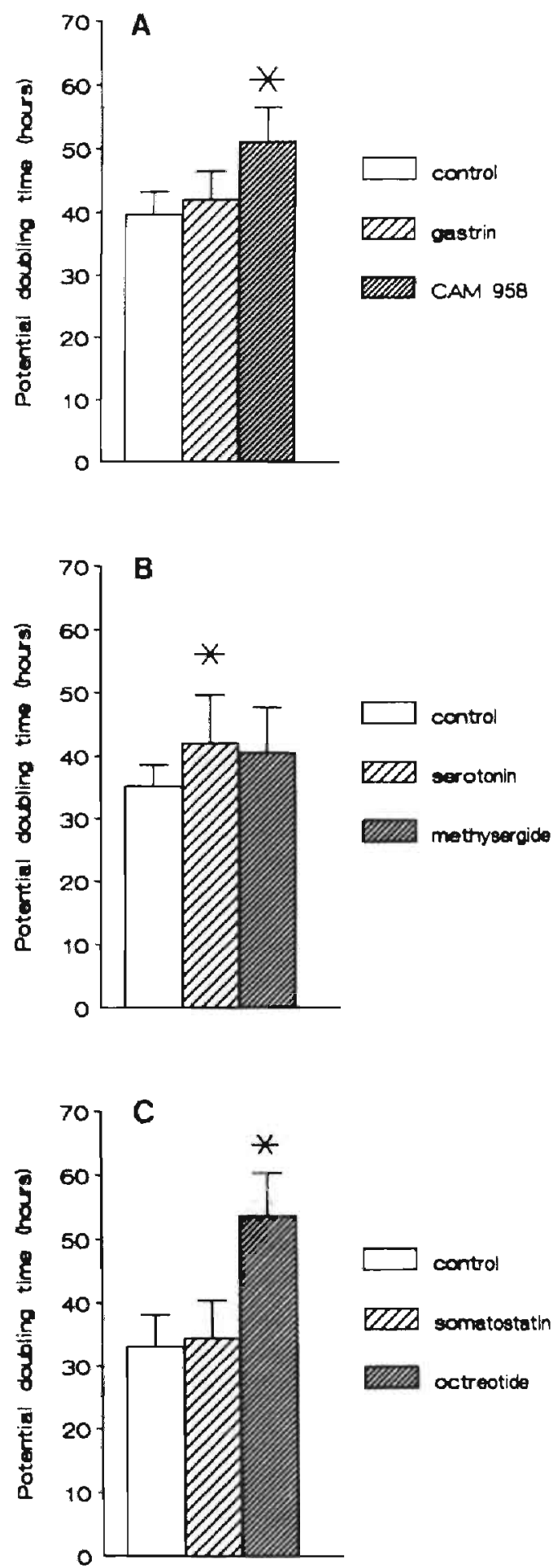

Figure 4. Results of cell cycle analysis by two-parameter flow cytometry in NCL-H716 colon cancer cells.

The cells were cultured in DMEM supplemented with $10 \%$ FBS in the presence or absence of neurohomones or (ant)agonists and pulse labeied with BrdU. The potential doubling time (Tpot) was calculated as described in the Materials and Methods section. The mean Tpot $\pm s . d$. from five separate experiments is presented; a. CAM 958 increases Tpot at a concentration of $500 \mathrm{nM}(\mathrm{p}<0.05)$. Gastrin has no effect; $b$. A slight increase of Tpot occurs in cells exposed to serotonin at $10 \mathrm{nM}(p=0.05)$, whereas methysergide at $10 \mu \mathrm{M}$ has no significant effect; c. Octreotide at $10 \mathrm{nM}$ significantly prolongs Tpot $(p<0.05)$, whereas somatostatin $(10 \mathrm{nM})$ has no effect. $\left({ }^{*}: p<0.05\right)$ 


\subsection{DISCUSSION}

Modulating effects of neurohormones on the growth of gastrointestinal tumor cells in vivo and in vitro have been described in several reports $(3,6,8,10,11,13$ 16,28-31). Our results with five established colon cancer cell lines indicate that four of these lines do not respond in vitro to gastrin, serotonin or somatostatin with altered proliferative behavior. Only the neuroendocrine NCI-H716 cells (27) were rescued from proliferation arrest under serumfree conditions by the addition of gastrin ( 1 and $10 \mathrm{nM})$ and serotonin $(1 \mathrm{nM})$, whereas somatostatin had no effect.

As a response to a neurohormone depends on the presence of a specific and functional receptor, we performed radioligand binding assays to detect gastrin, serotonin and somatostatin receptors on the colon cancer cells. Although receptors for gastrin, serotonin and somatostatin were detected to a variable extent in the non-endocrine HT 29, LoVo, LS 174T, and SW 403 cells, no growth modulating response to these neurohormones occurred. The absence of a proliferative response of these cells to the neurohormones corresponds with the lack of receptors. In agreement with our results, Watson et al. (16) also did not find a response of HT 29 and LoVo cells. However, for the non-endocrine cell lines our results are at variance with several other reports in the literature $(11,13-15)$. Whether this discrepancy is due to differences in receptor content of the cells is not clear, since no receptor data were presented in these studies. Receptor expression could have been lost during prolonged culturing of cell lines, as suggested by the results of Watson et al. (31) using primary colon cancer cultures. Although on SW 403 cells relative large numbers of gastrin and serotonin receptors were expressed, and in contrast to the report of Imdahl et al. (11), we could not detect a stimulating action of gastrin on SW 403 cells. In attempts to clarify whether experimental conditions of the ${ }^{3} \mathrm{H}$-thymidine incorporation assay or culturing conditions would preclude detection of a proliferative response in our study we used a variety of conditions.

The experiments with the ZR- 75 breast cancer cells, which showed that estradiol stimulated the incorporation of ${ }^{3} \mathrm{H}$-thymidine in a dose-dependent manner, validate the experimental design to measure proliferative activity in vitro. Culturing medium with complete serum presumably contains sufficient growth factors and/or neurohormones to cause an exponential growth rate, making further stimulation by added neurohormones highly unlikely. The experimental conditions, with synchronization and restricted growth of cells, render it unlikely that a growth modulating effect would remain undetected.

Neuroendocrine NCl-H716 cells expressed high numbers of receptors for the three neurohormones tested. Presumably the gastrin and serotonin effect on proliferative activity is mediated by these receptors. The increase of the potential doubling time by the gastrin antagonist CAM 958 and the increased incorpora- 
tion of ${ }^{3} \mathrm{H}$-thymidine induced by gastrin suggests a role for gastrin receptors in growth modulation of NCI-H716 cells. Serotonin $(10 \mathrm{nM})$ slightly inhibited proliferation in the flow cytometric assay, when $\mathrm{NCl}-\mathrm{H} 716$ cells grew in complete serum, which allows normal proliferative activity, but the effect was borderline significant. In conditions of restricted growth however, stimulation of ${ }^{3} \mathrm{H}$-thymidine incorporation was found upon exposure of cells to $1 \mathrm{nM}$ serotonin, whereas $10 \mathrm{nM}$ serotonin had no effect. This paradoxical effect points towards different effects exerted through different receptors with different affinities. In any case, a major role for serotonin in growth modulation of colon cancer cells seems unlikely.

The flow cytometric cell cycle analysis, which allows detailed study of the proliferative behavior of cycling cells, demonstrated that the somatostatin analogue octreotide significantly prolongs the potential doubling time of NCI-H716 cells, due to delayed traverse of the cell cycle. Strikingly, somatostatin did not show this effect, in spite of the presence of somatostatin receptors on the cells. As multiple receptor subtypes for somatostatin have been described (32), it is conceivable that octreotide exerts its effect by binding to a different receptor subtype on NCI-H716 cells than the receptor to which somatostatin binds.

Given our failure in repeating earlier results obtained in other studies, it seems justified to conclude that the growth modulating effect of gastrin, serotonin and somatostatin on non-neuroendocrine colon cancer cell lines is at least disputable, and, if measurable at all, not very significant.

Only in the neuroendocrine cell line NCl-H716 growth modulating effects, in particular of the somatostatin analogue octreotide, were observed in parallel with high receptor numbers. These data indicate that the influence of biogenic amines and polypeptide hormones on colorectal cancer growth might be confined to adenocarcinomas with neuroendocrine differentiation. Finally, our observations show that the presence of receptors for neurohormones does not imply that the cells will yield a proliferative response to a neurohormonal stimulus. 


\subsection{REFERENCES}

1. Solcia E, Capella C, Buffa R, Usellini L, Fiocca R, Sessa F. Endocrine cells of the digestive system. In: Physiology of the Gastrointestinal Tract, 2nd edition. Johnson LR ed, Raven Press, New York, 1987, pp.111-130.

2. Johnson LR. New aspects of the trophic action of gastrointestinal hormones. Gastroenterology 1977;72:788-792.

3. Singh P, Le S, Beauchamp RD, Townsend CM, Thompson JC. Inhibition of pentagastrin-stimulated up-regulation of gastrin receptors and growth of mouse colon tumor in vivo by proglumide, a gastrin receptor antagonist. Cancer Res 1987;47:5000-5004.

4. Johnson LR. Regulation of gastrointestinal mucosal growth. Physiol Rev 1988;68:456502.

5. Lehy T, Accary JP, Labeille D, Dubrasquet M. Chronic administration of bombesin stimulates antral gastrin cell proliferation in the rat. Gastroenterology 1983;84:914-919.

6. Moyer MP, Armstrong A, Aust B, Levine BA, Sirinek KR. Effects of gastrin, glutamine, and somatostatin on the in vitro growth of normal and malignant human gastric mucosal cells. Arch Surg 1986;121:285-288.

7. Conteas $\mathrm{CN}$, Majumdar AP. The effects of gastrin, epidermal growth factor, and somatostatin on DNA synthesis in a small intestinal crypt cell line (IEC-6). Proc Soc Exp Biol Med 1987; 184:307-311.

8. Tutton PJM, Barkla DH. Biogenic amines as regulators of the proliferative activity of nomal and neoplastic intestinal epithelial cells. Anticancer Res 1987;7:1-12.

9. Townsend CM Jr, Beauchamp RD, Singh P, Thompson JC. Growth factors and intestinal neoplasms. Am J Surg 1988; 155:526-536.

10. Watson S, Durrant L, Morris D. Gastrin: growth enhancing effects on human gastric and colonic tumour cells. Br J Cancer 1989;59:554-558.

11. Imdahl A, Eggstein S, Crone C, Farthmann EH. Growth of colorectal carcinoma cells: regulation in vitro by gastrin, pentagastrin and the gastrin-receptor antagonist proglumide. J Cancer Res Clin Oncol 1989;115:388-392.

12. Simopoulos C, Gaffen JD, Bennett A. Effects of gastrointestinal hormones on the growth of human intestinal epithelial cells in vitro. Gut 1989;30:600-604.

13. Palmer Smith J, Solomon TE. Effects of gastrin, proglumide, and somatostatin on growth of human colon cancer. Gastroenterology 1988;95:1541-1548.

14. Kusyk CJ, McNiel NO, Johnson LR. Stimulation of growth of a colon cancer cell line by gastrin. Am J Physiol 1986;251:G597-601.

15. Sirinek KR, Levine BA, Moyer MP. Pentagastrin stimulates in vitro growth of normal and malignant human colon epithelial cells. Am J Surg 1985;149:35-39.

16. Watson SA, Durrant LG, Morris DL. Growth-promoting action of gastrin on human colonic and gastric tumour cells cultured in vitro. Br J Surg 1988;75:342-345.

17. Seuwen K, Magnaldo I, Pouyssegur J. Serotonin stimulates DNA synthesis in fibroblasts acting through 5-HTIB receptors coupled to a Gi-protein. Nature 1988;335:254-256.

18. Lamberts SWJ, Krenning EP, Reubi J-C. The role of somatostatin and its analogs in the diagnosis and treatment of tumors. Endocrine Rev 1991;12:450-482.

19. Pelicci G, Pagliacci MC, Lanfrancone L, Pelicci PG, Grignani F, Nicoletti I. Inhibitory effect of the somatostatin analog octreotide on rat pituitary tumor cell (GH3) proliferation in vitro. J Endocrinol Invest 1990;13:657-662. 
20. Singh $\mathrm{P}$, Walker JP, Townsend $\mathrm{CM}$, Thompson JC. Role of gastrin and gastrin receptors on the growth of a transplantable mouse colon carcinoma (MC-26) in Balb/c mice. Cancer Res 1986;46:1612-1616.

21. Weinstock J, Baldwin GS. Binding of gastrin-17 to human gastric carcinoma cell lines. Cancer Res 1988;48:932-937.

22. Upp JR, Singh P, Townsend CM, Thompson JC. Clinical significance of gastrin receptors in human colon cancers. Cancer Res 1989;49:488-492.

23. Singh P, Rae-Venter B, Townsend CM, Khalil T, Thompson JC. Gastrin receptors in normal and malignant gastrointestinal mucosa: age-associated changes. Am J Physiol 1985;249:G761-769.

24. Schutte B, Reynders MMJ, Bosman FT, Blijham GH. Studies with anti-bromodeoxyuridine antibodies: II Simultaneous immunocytochemical detection of antigen expression and DNA synthesis by in vivo labeling of mouse intestinal mucosa. J Histochem Cytochem 1987;35:371-374.

25. Begg AC, McNally NJ, Shrieve DC, Kärcher $\mathrm{H}$. A method to measure the duration of DNA synthesis and the potential doubling time from a single sample. Cytometry 1985;6:620-626.

26. White RA, Terry NHA, Meistrich ML, Calkins DP. Improved method for computing potential doubling time from flow cytometric data. Cytometry 1990;11:314-317.

27. De Bruïne AP, Dinjens WNM, Pijls MMJ, Van der Linden EPM, Rousch MJM, Moerkerk PT, De Goeij AFPM, Bosman FT. NCl-H716 cells as a model for endocrine differentiation in colorectal cancer. Virchows Arch B Cell Pathol 1992;62:311-320.

28. Winsett OE, Townsend CM, Glass EJ, Thompson IC. Gastrin stimulates growth of colon cancer. Surgery 1986;99:302-307.

29. Goodlad RA, Wright NA. Peptides and epithelial growth regulation. Experientia 1987:43:780-784.

30. Conteas CN, Desai TK, Arlow FA. Relationship of hormones and growth factors to colon cancer. Gastroenterol Clin North Am 1988;17:761-772.

31. Watson SA, Durrant LG, Crosbie JD, Morris DL. The in vitro growth response of primary human colorectal and gastric cancer cells to gastrin. Int J Cancer 1989;43:692696.

32. Yamada Y, Post SR, Wang K, Tager HS, Bell GI, Seino S. Cloning and functional characterization of a family of human and mouse somatostatin receptors expressed in brain, gastrointestinal tract, and kidney. Proc Natl Acad Sci USA 1992;89:251-255. 


\section{CHAPTER 7}

\section{ENDOCRINE CELLS IN COLORECTAL ADENOCARCINOMAS: INCIDENCE, HORMONE PROFILE AND PROGNOSTIC RELEVANCE}

A.P. de Bruïne, Th. Wiggers, C. Beek, A. Volovics, M. von Meyenfeldt, J.W. Arends, and F.T. Bosman. 


\subsection{INTRODUCTION}

Endocrine cells occur in colorectal epithelium together with columnar cells and mucin producing goblet cells. These three lineages are considered to be the progeny of a common endodermal stem cell, located in the base of the intestinal crypt (1). Colorectal carcinomas with endocrine features encompass a spectrum of varying differentiation, ranging from carcinoid tumors to poorly differentiated small cell carcinomas with neuroendocrine features. In adenocarcinomas, the most prevalent type of colorectal cancer, endocrine cells occur to a variable extent $(2,3)$. This feature is also found in other parts of the digestive tract (4) as well as in other organ systems (5). Interest in this phenomenon is increasing, in connection with reports that endocrine features in tumors correlate with poorer prognosis $(6,7)$. Hypothetically, this could be explained by relative immaturity of tumor stemcells which have retained their capacity for endocrine differentiation (8). Alternatively, endocrine tumor cells could stimulate tumor growth through secretion of tumor cell growth promoting neurohormonal substances (9). The matter of prognosis of colorectal adenocarcinomas containing endocrine cells has not yet been settled, because studies with reliable follow up data are scarce, and the studies which have been performed have generated conflicting results. Previously we reported a tendency for poorer prognosis of adenocarcinomas with serotonin (5-HT) expression (6), contradicting some earlier reports, which denied any effect of endocrine differentiation on prognosis (10). The data on 5-HT expression in adenocarcinomas barely reached statistical signifance, perhaps because the number of 5-HT positive cases was too small, or the follow up period too short for definitive conclusions. In an attempt to resolve this issue we investigated endocrine differentiation in the same series of colorectal cancer patients, now with longer follow up data available. We reexamined 5-HT expression and added immunostaining for chromogranin A (CGA), a soluble monomeric acidic protein present in dense core neurosecretory granules which so far is the most sensitive and specific general neuroendocrine (NE) marker (11).

The present study reports on the frequency and pattem of endocrine differentiation in colorectal adenocarcinomas, the hormone profile of endocrine tumor cells, and the prognostic relevance of endocrine differentiation in colorectal cancer.

\subsection{MATERIAL AND METHODS}

\subsubsection{Patients}

Colorectal adenocarcinomas from 350 patients were studied for the presence of endocrine differentiation. These patients were entered in two multicenter pro- 
spective clinical trials between 1979 and 1981. One trial was designed to compare patient survival after treatment of colonic cancer by conventional surgery or the no-touch isolation technique (12). The other trial was conducted to compare survival in rectal cancer patients with or without pre-operative radiotherapy. Follow up took place every 3 months during the first three years and every 6 months between three and five years after initial diagnosis and surgery. Standard protocols were followed, with routine blood counts and chemistry studies (including CEA levels) at each visit and liver ultrasound, chest $x$-ray and colonoscopy annually, to evaluate both recurrence of disease and disease-related death. After the initial five year follow up period, during the next years only the time and cause of death were registered. In the present study, failure was defined as death due to recurrent disease, excluding postoperative mortality within 30 days and non-disease related death.

\subsubsection{Pathological staging and grading}

Tumor stage, differentiation grade, size, (lymph-)angioinvasion and perineural invasion, and the presence of central lymph node involvement were assessed. A clinicopathological staging derived from the original Dukes' classification (13) was used. Stage A tumors were confined to the bowel wall, stage B tumors were defined as extending into the pericolic/-rectal fat and/or beyond the serosa, stage $\mathrm{C}$ tumors were either stage $\mathrm{A}$ or $\mathrm{B}$ with lymph node metastases. Stage D was defined as infiltrative growth in adjacent organs or distant metastases.

Histological differentiation was assessed according to modified criteria as outlined by Blenkinsopp (14), and was based on the extent of gland formation within the tumor. Well-differentiated tumors consisted almost entirely of well developed glands, poorly differentiated tumors displayed a solid growth pattern in $10 \%$ or more of the tumor, and moderately differentiated tumors showed intermediate patterns. Undifferentiated tumors, lacking gland formation, were few in number and were included in the poorly differentiated group. Grading was performed in at least two different representative sections and was based on the least differentiated areas. With regard to size, tumors were assigned to three groups, depending on the largest diameter measured. Cutpoints were $3.5 \mathrm{~cm}$. and $6 \mathrm{~cm}$. Microscopic invasion in vessels or nerves was studied for at least $20 \mathrm{~min}$. per $H \& E$ section. Central lymphnode invasion was defined as tumor positive lymph nodes in proximity of the highest vascular ligature.

\subsubsection{Histochemistry and immunohistochemistry}

Colorectal tumor specimens were fixed in $10 \%$ neutral buffered formalin. Representative samples of the tumors were routinely processed and embedded in paraffin. Sections $(4 \mu \mathrm{m})$ of the tumor, through its most invasive part and including adjacent transitional mucosa, were stained by standard histochemical and immunohistochemical techniques. For the latter, an indirect peroxidase 
TABLE 1. Applied Staining Techniques

Histochemistry

High-Iron-Diamine Alcian Blue (HID-AB)

Applied Antibodies (nature, source, type, dilution)

\section{Intestinal Differentiation Markers}

-Columnar cells

-Goblet cells

-Endocrine cells
Secretory Component

Mucin (Parlam 3)

Chromogranin A

Synaptophysin

NSE

Leu-7
DAKO-pc-1:1000

own lab-mc-1: 1000

Hybritech-mc-1:12500

Progen-mc-1:500

DAKO-pc-1:1000

BD-mc-1:50

II. Hormone Profile

$\begin{array}{lll}\text {-Gastrointestinal-Colon } & \text { Serotonin (5-HT) } & \text { own lab-pc-1:2000 } \\ & \text { Somatostatin } & \text { own lab-pc-1:1500 } \\ & \text { Glucagon-like immunoreactivity } & \text { own lab-pc-1:100 } \\ & \text { (GLI) } & \\ & \text { Glicentin } & \text { ED-pc-1:200 } \\ & \text { PYY } & \text { ED-pc-1:50 } \\ \text {-Gastrointestinal-Other } & \text { Gastrin } & \text { own lab-pc-1:250 } \\ & \text { Bombesin/GRP } & \text { ICN-pc-1:10000 } \\ & \text { Glucagon } & \text { own lab-pc-1:500 } \\ & \text { Pancreas Polypeptide } & \text { own lab-pc-1:250 } \\ & \text { Neurotensin } & \text { Amersham-pc-1:2000 } \\ & \beta H C G & \text { DAKO-pc-1:2000 } \\ \text {-Extra-intestinal } & \alpha H C G & \text { own lab-pc-1:3000 } \\ & \text { ACTH } & \text { own lab-pc-1:100 }\end{array}$

III. 2nd Antibodies

$\begin{array}{ll}\text { Swine-anti-rabbit } & \text { DAKO-1:150 } \\ \text { Rabbit-anti-mouse } & \text { DAKO-1:200 }\end{array}$

labeled antibody technique was performed. The applied staining techniques are listed in Table 1. The stainings were chosen to 1) demonstrate endocrine cells, 2) investigate the hormone profile of endocrine tumor cells, and 3) identify other colorectal epithelial cell lineages within the tumor.

When transitional mucosa as an intemal control was lacking, sections with normal colon mucosa served as positive controls. Appropriate control tissues from various endocrine organs were used as positive controls for determination 
of the hormone profile. Negative controls consisted of omission of the primary antibody or replacement by serum from a non-immunized animal.

\subsubsection{Scoring of endocrine cells}

One representative section of each tumor was investigated for the presence of tumor cells immunoreactive for chromogranin A (CGA). Sections containing insufficient amounts of tumor tissue were excluded. Only tumors in which CGA immunoreactivity was clearly identified as an integral part of the tumor were considered to be positive. This was the case when the CGA positive cells were found in invasive parts of the tumor, in lymph node metastases or when the cells clearly showed malignant cytonuclear features. Intramucosal CGA positive cells were discarded, to exclude the possibility of inclusion of benign mucosal endocrine cells by the tumor. Tumors with CGA positivity were scored as focally positive, when immunoreactivity was restricted to certain areas of the section, or diffusely positive when CGA positive cells were found throughout the section. Furthermore, the number of CGA positive tumor cells was counted per $\mathrm{mm}^{2}$ of tumor surface area, using a gridded eyepiece, at a magnification of $312.5 x$. When the number of CGA cells was less than 1 per $\mathrm{mm}^{2}$ focal or diffuse in the section, this was designated "moderate positivity" (class I), whereas a number exceeding 1 per $\mathrm{mm}^{2}$ was designated "extensive positivity" (class II) (Fig. 1).

\subsubsection{Other colorectal markers}

CGA expression was compared with markers for other colorectal epithelial cell lineages. Mucin production was detected with the High Iron Diamine-Alcian Blue (HID-AB) technique, which stains sulphated and sialated mucopolysaccharides, and with the monoclonal antibody Parlam 3 (P3), detecting a glycoprotein present in normal goblet cells (15). Columnar cells were identified by immunoreactivity for secretory component (SC). For comparison with CGA expression, immunoreactivity for these markers was interpreted as positive or negative, without further specification of staining patterns, some of which have been reported in more detail previously (6).

\subsubsection{Statistical analysis}

The correlation between endocrine differentiation (defined by CGA immunoreactivity) and other colorectal differentiation markers, Dukes' stage, differentiation grade, tumorsize, patient age, localization of the tumor within the large intestine, presence of (lymph-)angioinvasion or perineural invasion, lymphnode status, and central lymphnode involvement was investigated by two-way and multiway frequency tables using BMDP PC90 Statistical Software, program 4F (BMDP Statistical Software, Inc., Los Angeles, CA). Interdependency of en- 

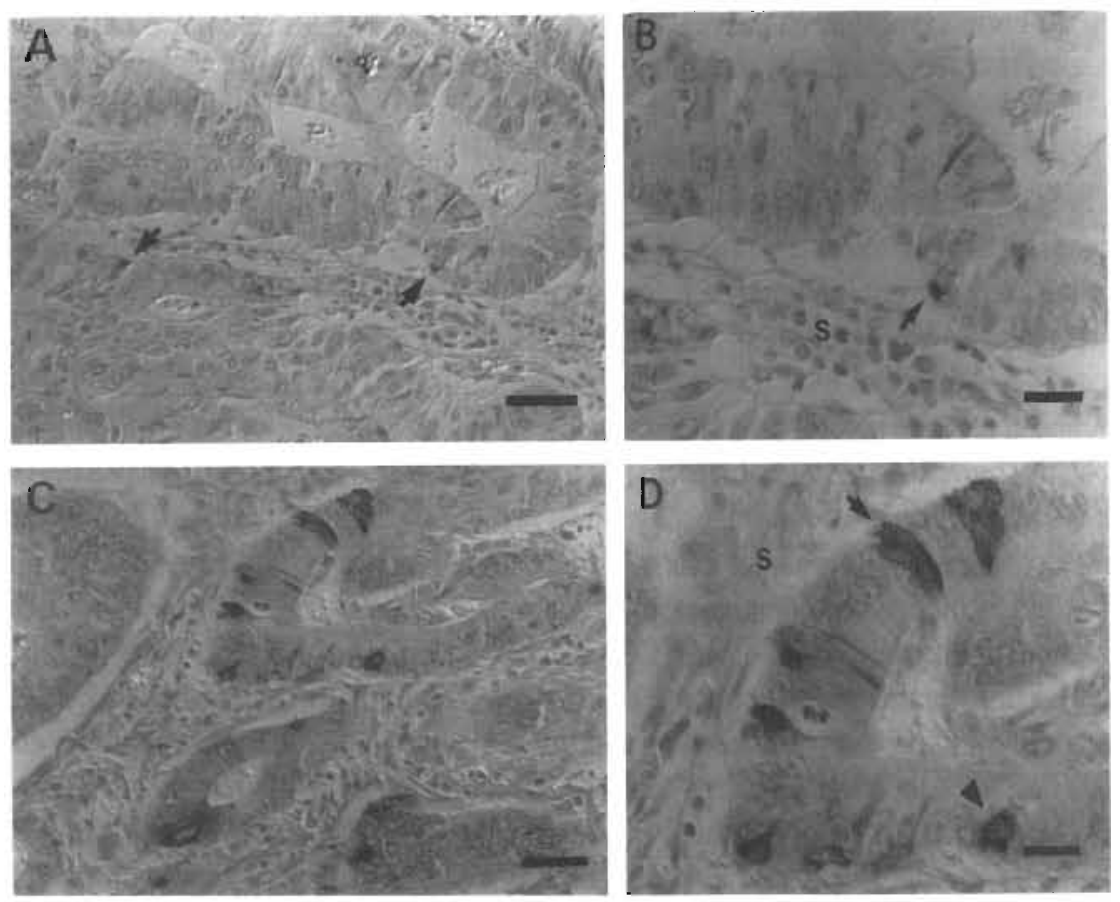

Figure 1. Chromogranin A (CGA) positive tumor cells in colorectal adenocarcinomas. a. Class I pattern of immunoreactivity (moderate positivity, $<1 \mathrm{cell} / \mathrm{mm}^{2}$ ). Arrows indicate two CGA positive cells. b. detail of a., showing subnuclear immunostaining for CGA (arrow) in a tumor cell making contact with stroma (s). c. Class II pattem of immunoreactivity (extensive positivity, $>1 \mathrm{cell} / \mathrm{mm}^{2}$ ). d. detail of $\mathrm{c}$., showing CGA positive tumor cells of "open" type (arrow) and of "closed" type (arrowhead), resembling normal enteroendocrine cells. (a. and c.: bars $=50 \mu \mathrm{m}$; b. and d.: bars $=25 \mu \mathrm{m}$ )

docrine differentiation and these variables was tested with Pearson's chisquare test.

The prognostic status of endocrine differentiation with respect to survival was investigated by univariate analysis, using (stratified) Kaplan-Meier estimations and the logrank test, with the program EGRET ${ }^{R}$ (Epidemiological GRaphics, Estimation, and Testing, Statistics and Epidemiology Research Corporation, Seattle, Washington).

The prognostic status of endocrine differentiation in relation to other known important prognostic factors (Dukes'stage, differentiation grade, tumorsize and central lymphnode involvement) was investigated by multivariate analysis in Cox's proportional hazards regression model, using the PHREG procedure of SAS/STAT (SAS Institute Inc. 1991, SAS Technical Report P-217, SAS/STAT Software: The PHREG Procedure, Version 6, Cary, NC). Model assumptions 
and model fit were carefully checked using graphical methods and these checks gave satisfactory results. To include all patients in the analyses, dummy variables were defined and used for parameters with missing values. For CGA and 5-HT expression, the missing-nonmissing patterns showed no statistically significant association with survival.

\subsection{RESULTS}

\subsubsection{Patients}

The 350 patients in this study consisted of 165 men and 185 women, ranging in age from 29 to 91 years. The median age was 69 years. There were 301 colonic adenocarcinomas and 49 rectal adenocarcinomas. Of the tumors 78 were Dukes' A, 132 Dukes' B, 99 Dukes' C and 40 Dukes' D (one case was not staged). The number of well differentiated tumors was 35,264 were moderately differentiated and 35 poorly differentiated ( 16 cases were not graded).

\subsubsection{Chromogranin A expression}

CGA staining was obtained in 311 out of 350 tumors. These were comparable in Dukes' stage and histologic grade to the overall population. CGA positive tumor cells, characterized by intense granular staining of part or all of the cytoplasm (Fig. 1), were found in 92 cases ( $30 \%$ ). In 62 cases ( $20 \%$ ), immunoreactivity was focal, in one or more areas of the section; 30 cases (10\%) showed diffuse presence of endocrine cells throughout the section. Of the CGA positive cases $64(21 \%)$ were class I and $28(9 \%)$ were class II. CGA positive tumor cells were often localized at the periphery of tumor cell nests, apposing stroma. The endocrine cells were comparable in size and nuclear features to surrounding tumor cells. They formed an integral part of tumors, being present also in invasive parts of tumors and in lymphnode metastases. In shape CGA positive tumor cells resembled normal enteroendocrine cells of open or closed type. Carcinoma cells surrounding CGA positive cells were morphologically similar to carcinoma cells in CGA negative areas.

\subsubsection{Hormone profile}

Twenty CGA positive tumors were assessed for expression of general NE markers and for a selection of neurohormonal peptides. Dukes' stage, grade and anatomical localization in these 20 cases were comparable to the overall group of CGA positive tumors. The general NE markers NSE and synaptophysin were each found in two cases (10\%). Leu-7 was co-expressed with synaptophysin in one of these cases $(5 \%)$. Of the polypeptide hormones indigenous to normal colonic epithelium, glucagon-like immunoreactivity (GLI) was encountered most, in 11 cases $(55 \%)$. Two of these (overall $10 \%$ ) also showed immunoreac- 
tivity for glicentin. Somatostatin (SS) immunoreactivity was found in 2 cases $(10 \%)$, both cases also expressing GLI. PYY was demonstrated in 2 cases $(10 \%)$, in one case together with GLI and SS, and once separately. Two cases $(10 \%)$ were positive for both $\alpha$ and $\beta$ HCG. In these cases staining for large intestinal neurohormonal peptides was not found. No immunoreactivity was observed for other gastrointestinal hormones (gastrin, bombesin/GRP, neurotensin, pancreatic glucagon, pancreatic polypeptide) or ACTH. Six cases (30\%) were negative for all neurohormonal peptides.

Expression of the biogenic amine serotonin (5-HT) had been previously determined in the same series of patients (6). Cross-tabulation between both studies showed that 5-HT immunoreactivity was present in 17 of 84 CGA positive cases $(20 \%)$.

\subsubsection{Endocrine differentiation vs. other colorectal markers}

Mucin production as assessed by HID-AB staining occurred in $38 \%$ of tumors. Mucin production detected by immunoreactivity for $\mathrm{P} 3$ was found in 52\% of tumors. P3 expression showed a highly significant correlation with the HID-AB method ( $\mathrm{p}<0.0001$ ), especially in sialomucin producing tumors, where overlap was $100 \%$ (for sulphomucin this was $81 \%$, for combined sulpho- and sialomucins $89 \%$ ). The correlation between CGA expression and HID-AB positive staining was of borderline significance $(\mathrm{p}=0.06)$. Especially tumors with sialomucin showed a high percentage of CGA positivity ( $48 \%$, of which $32 \%$ were class I and $16 \%$ class II). The correlation between CGA and P3 expression was significant $(\mathrm{p}=0.001)$. Of $\mathrm{P} 3$ positive tumors $39 \%$ showed CGA staining ( $26 \%$ class I, $13 \%$ class II), vs. $19 \%$ of P3 negative tumors (14\% class I, $5 \%$ class II). $58 \%$ of all tumors showed immunoreactivity for SC. No significant correlation was found between CGA and SC expression ( $\mathrm{p}=0.24)$. The correlation between $\mathrm{SC}$ and P3 was highly significant $(\mathrm{p}<0.0001)$. The frequency of various combinations of endocrine (CGA), mucin producing (P3) and columnar cells (SC) in colorectal adenocarcinomas $(\mathrm{n}=285)$ is shown in Table $2.21 \%$ of tumors were negative for all markers. $17 \%$ showed presence of all three lineages. $\ln 6 \%$ of adenocarcinomas CGA immunoreactivity was the only histochemical feature.

\subsubsection{Endocrine differentiation vs, other variables}

Adenocarcinomas with endocrine differentiation were found more frequently in patients under 70 years of age ( $35 \%$ vs. $24 \%$; $p=0.03$ ). There was a tendency for adenocarcinomas with endocrine differentiation to occur in the ascending colon (50\%) and also in the splenic flexure and descending colon (38\% and 37\% respectively); overall however, there was no sigificant correlation with tumor localization ( $p=0.18$ ). CGA positive adenocarcinomas were found significantly more often in cases with central lymph node involvement ( $42 \%$ vs. $29 \%$, $\mathrm{p}=0.004$ ). Also, the percentage of tumors belonging to class II was relatively 
TABLE 2. Correlation between endocrine differentiation (CGA), mucin production (P3) and columnar cell features (SC) $(n=285)$

\begin{tabular}{lllll}
\hline \multirow{2}{*}{ Secretory component } & \multirow{2}{*}{ Parlam 3 } & \multicolumn{2}{l}{ Chromogranin A } & Total \\
& & Neg & Pos & \\
& & & & \\
Neg & neg & $59(21 \%)$ & $17(6 \%)$ & $76(27 \%)$ \\
& pos & $30(10 \%)$ & $11(4 \%)$ & $41(14 \%)$ \\
& total & $89(31 \%)$ & $28(10 \%)$ & $117(41 \%)$ \\
Pos & & & & \\
& neg & $49(17 \%)$ & $9(3 \%)$ & $58(20 \%)$ \\
& pos & $63(22 \%)$ & $47(17 \%)$ & $110(39 \%)$ \\
& total & $112(39 \%)$ & $56(20 \%)$ & $168(59 \%)$ \\
\hline
\end{tabular}

high when the central node was positive ( $27 \%$ vs. $7 \%$ ). There was a tendency for endocrine differentiation to correlate with greater tumor size (22\% CGA positive in tumors $<3.5 \mathrm{~cm} ., 35 \%$ between 3.5 and $6.0 \mathrm{~cm}$., $29 \%>6.0 \mathrm{~cm}$; $\mathrm{p}=0.08$ ). No correlation was found between endocrine differentiation and Dukes' stage, grade, presence of angioinvasion or perineural invasion, or lymph node status $(\mathrm{p}>0.40)$.

\subsubsection{Prognostic implications}

Mean follow up was 11.5 years. One patient was lost to follow up, leaving 310 remaining cases. CGA positive and negative cases were fairly evenly distributed over the different therapy groups ( $\mathrm{p}=0.92$ for no-touch vs. conventional surgery; $\mathrm{p}=0.63$ for the pre-operative radiotherapy trial).

In univariate analysis, survival for all adenocarcinomas with endocrine differentiation tended to be poorer than for non-endocrine tumors ( $p=0.068$ ) (Fig. 2). This difference in survival did not correlate with focal or diffuse staining for CGA $(p=0.173)$. However, CGA class II tumors in univariate analysis showed a tendency towards shorter survival than CGA negative tumors $(\mathrm{p}=0.064)$, whereas class I cases showed no difference $(p=0.433$ ) (Fig. 3). The overall scoretest was not significant $(p=0.102)$. Stratification for tumor stage showed that class II tumors showed a significantly poorer prognosis within Dukes' $\mathrm{C}$ stage ( $p=0.028$, overall scoretest $p=0.08$ ) (Fig. 4). In other Dukes' stages no additional prognostic information could be derived from the class II pattern of endocrine differentiation ( $p>0.34)$. When all adenocarcinomas with endocrine features were grouped together, no additional prognostic information was found upon stratification for stage ( $p>0.14$ ), nor did focal or diffuse CGA staining within the various Dukes' stages influence prognosis ( $p>0.28$ ). The prognostic 


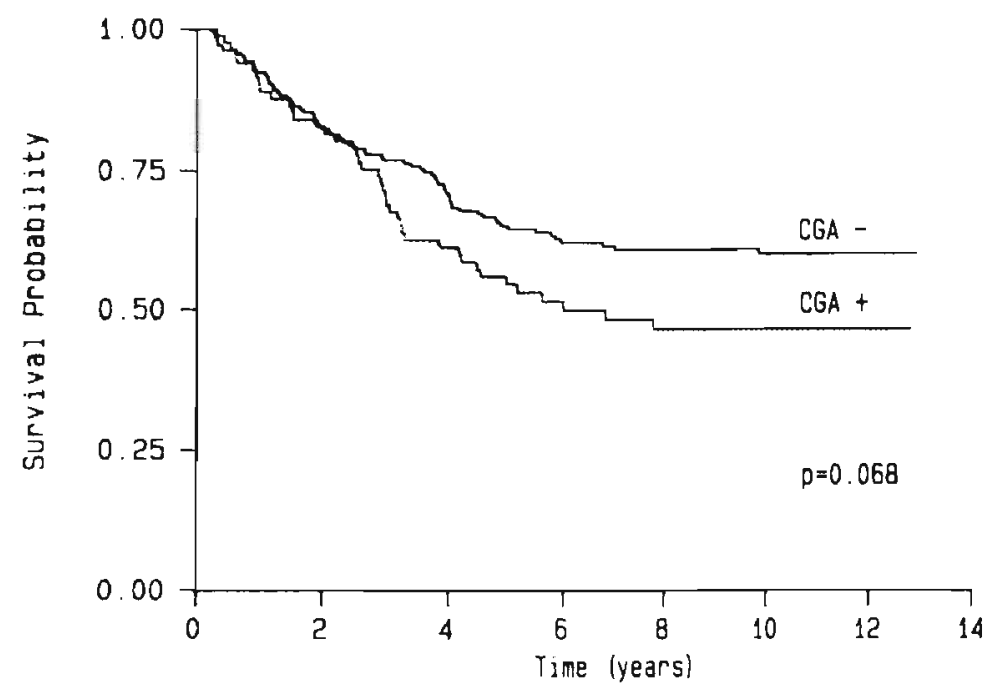

Figure 2. Kaplan-Meier estimation survival curve for the overall group of chromogranin A positive (CGA +) vs. chromogranin A negative (CGA -) adenocarcinomas. Tumors with endocrine features show a tendency towards shorter survival (univariate analysis, logrank test: $p=0.068$ ).

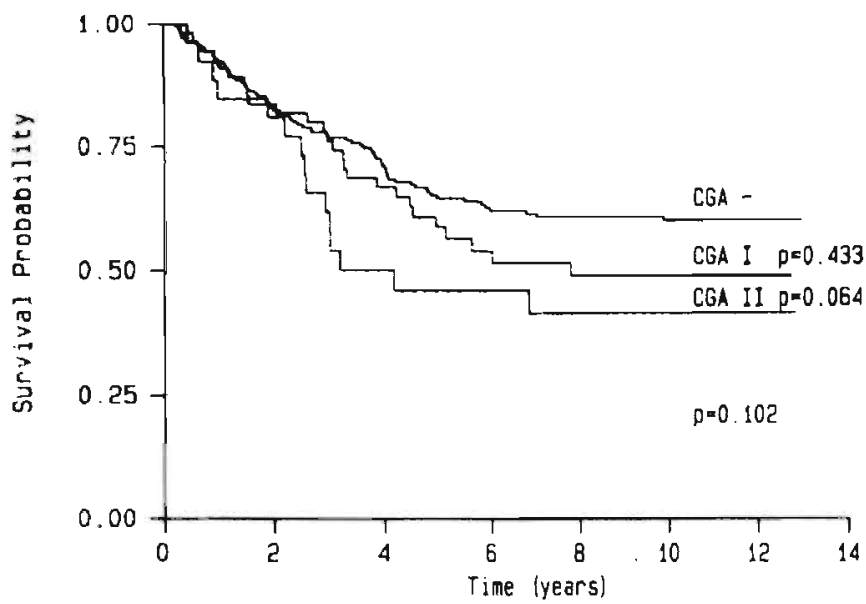

Figure 3. Kaplan-Meier estimation survival curve showing that adenocarcinomas with extensive positivity for chromogranin A (Class II, CGA II) tend to behave more aggressively than tumors lacking endocrine features (CGA -) (univariate analysis, logrank test: $p=0.064$ ). No significant difference in survival was noted for adenocarcinomas with moderate positivity for chromogranin A (Class I, CGA I) (univariate analysis, logrank test: $p=0.433$, overall scoretest $p=0.102$ ). 


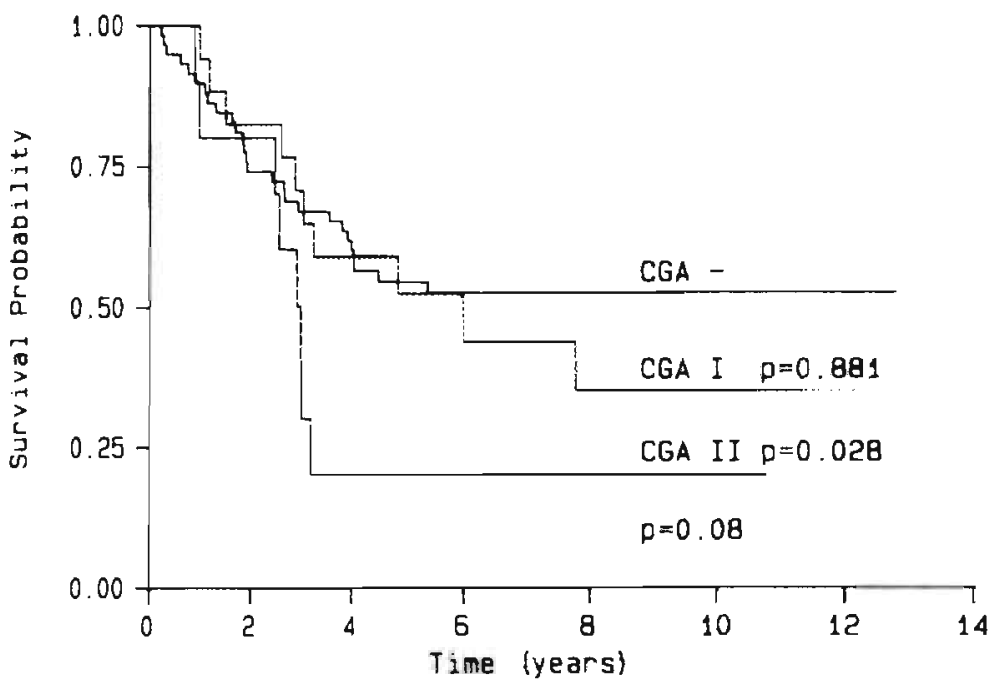

Figure 4. Kaplan-Meier estimation survival curve for Dukes' $\mathrm{C}$ stage adenocarcinomas. Class II chromogranin A positive tumors (CGA II) show worst prognosis within this stage (univariate analysis, logrank test: $p=0.028$ ). No significant difference in survival was found for Class I positive tumors (CGA I) (univariate analysis, logrank test: $p=0.881$, overall scoretest $p=0.08$ ).

relevance of 5-HT expression in adenocarcinomas in univariate analysis did not increase with longer follow up (5 year f.u. $p=0.168,11.5$ year f.u. $p=0.163$ ). 5-HT expression did not alter prognosis within the various Dukes' stages and did not have an additional effect on prognosis of CGA positive cases.

For multivariate analysis, traditional factors determining prognosis in colorectal cancer were taken into account. Endocrine differentiation as such did not reach statistical significance as an independent prognostic factor $(\mathrm{p}=0.114)$. The adverse prognostic effect of endocrine differentiation was confined to tumors belonging to class II, and was even more significant than in univariate analysis $(\mathrm{p}=0.015)$. In multivariate analysis, tumors with a diffuse pattern of CGA staining also tended to have an unfavorable prognosis $(p=0.078)$. As opposed to univariate analysis, 5-HT immunoreactivity in the multivariate analysis turned out to be an independent predictor of poor outcome $(p=0.010)$. Co-expression of 5-HT and CGA did not have an additive effect on prognosis.

In tumors with mucin and/or SC production, the presence of CGA positive cells did not have any bearing on prognosis ( $p>0.27$ ). Compared with tumors showing only mucin or SC production and tumors without immunoreactivity at all, tumors with CGA immunoreactivity as only marker of differentiation ( $6 \%$ of cases) had the poorest prognosis ( $p<0.001$ ) (Fig. 5). 


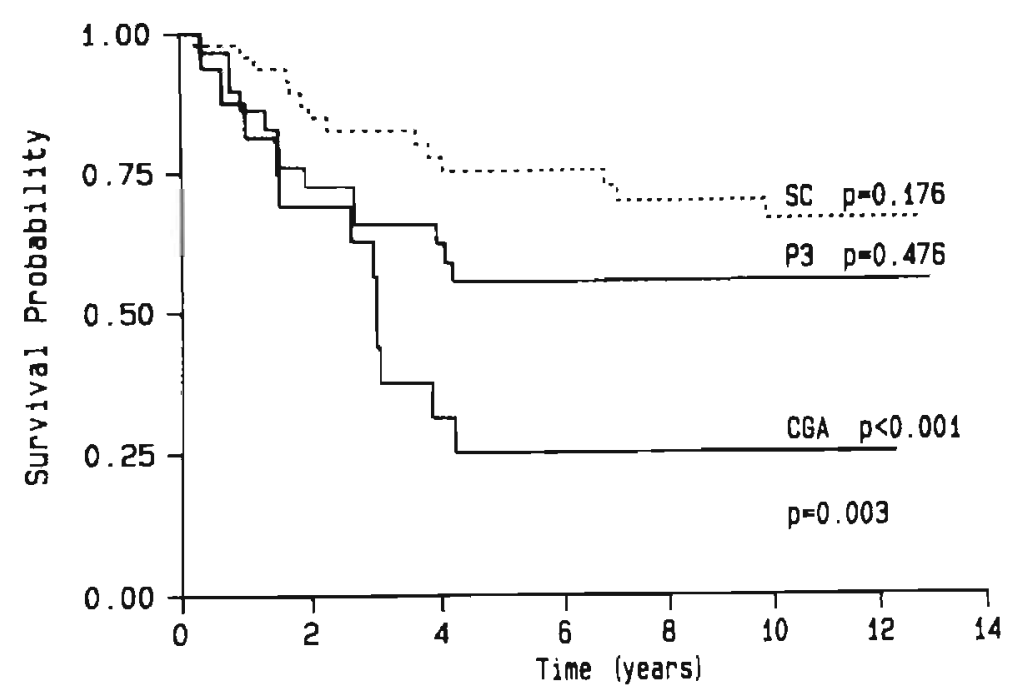

Figure 5. Kaplan-Meier estimation survival curve for adenocarcinomas exclusively showing endocrine differentiation (CGA, $n=17$ ), mucin production ( $P 3, n=30$ ), and columnar cell features ( $S C, n=49$ ). CGA tumors show shortest survival (univariate analysis, logrank test: $p<0.001)$, SC tumors appear to survive longest $(p=0.176)$ and P3 tumors behave intermediately ( $p=0.476$, overall scoretest $p=0.003$ ).

\subsection{DISCUSSION}

Endocrine differentiation in gastrointestinal tumors initially was thought to be confined to carcinoids. Later, composite tumors were recognized, characterized by combinations of argentaffin cells and mucus-secreting acini. In the last two decennia, histochemical, immunohistochemical and ultrastructural studies have led to the recognition that endocrine cells (ECs) also occur quite frequently in non-endocrine tumors. This has culminated in the concept of a broad spectrum of tumors with endocrine features of varying differentiation, which can arise along the entire digestive tract (3), in the bronchopulmonary system (16) and in other organ systems (5). Although this concept may have been interesting from a histogenetic point of view, in challenging the original APUD-cell hypothesis (17), it remained of trivial importance until tumor behavior and prognosis were reported to differ from tumors lacking ECs $(5,6)$. More well-documented patient series need to be investigated in order to sufficiently prove this contention. In the large intestine, relatively few studies on the occurrence of ECs in adenocarcinomas have been performed. The first studies employed silver-impregnation histochemistry. Iwashita (18) identified argyrophil cells in $44 \%$ of 
colorectal carcinomas. Smith and Haggitt (10) used the Churukian-Schenk argyrophil stain and found $20 \%$ of colorectal carcinomas to contain ECs. Arends et al. (6) were the first to systematically look for endocrine features in colorectal tumors with immunohistochemistry, and found that $8 \%$ of tumors contained 5 -HT immunoreactive cells. This relatively low percentage is accounted for by the fact that 5-HT is only present in a subset of tumors with endocrine differentiation, as became evident in the present study. When the same series of patients was stained with a monoclonal antibody against CGA, the percentage of positive tumors increased to $30 \%$. This percentage corresponds with traditional silver stainings, which is not surprising, as CGA immunoreactivity identifies the same cell constituents as argyrophil stains. The percentage of CGA positivity in this report is also comparable with the literature. Ho et al. (2) reported CGA expression in 33\%, and Hamada et al. (19) in 32.5\% of tumors. Jansson et al. (7) found a higher percentage (app. 50\%) of endocrine differentiation in a relatively small group of colon carcinomas by using combined immunohistochemistry for several general neuroendocrine (NE) markers, including CGA and neurohormones. In this study, preliminary clinical data indicated a worse prognosis for both pure NE carcinomas and carcinomas containing a NE subpopulation, even if small. Smith and Haggitt (10) in their study did not find a correlation between endocrine differentiation and poorer prognosis. This contrasts with the report of Arends et al. (6) on 5-HT positive tumors, with the study of Hamada et al. (19) and with our results on CGA expression. Hamada et al. (19) reported results which are highly similar to ours. They also found a worse prognosis for carcinomas containing relatively high amounts of CGA positive cells ( $\mathrm{p} \cdot 0.01$ ). This group was slightly larger than in our study (14\% vs. 9\%). A similar effect was found in patients with lymph node negative tumors $(p<0.05)$. In contrast, in our study, this effect was mainly present in Dukes' $C$ tumors. Also, there were differences in patient material: Hamada et al. studied 97 colon cancer cases and 115 rectal adenocarcinomas, whereas in our study predominantly colon carcinomas were present. Apart from these minor differences, the two similar studies, in two independent patient populations, provide strong evidence for a more aggressive behavior of colorectal adenocarcinomas with ECs.

In explanation of the occurrence of ECs in colorectal cancer, polyclonality of the tumor and pluripotentiality of tumor stem cells should be considered. As regards the first possibility, the weight of evidence is that most neoplasms are of monoclonal origin. Pluripotentiality of tumor stem cells seems to offer a more plausible explanation for ECs in non-endocrine tumors. In normal intestinal epithelium, conclusive evidence has been generated that all cell lineages are derived from a common endodermal stem cell (1). Evidence in favor of a pluripotential tumor stem cell has been obtained from a rat model of colonic adenocarcinoma (20) and in various human adenocarcinoma cell lines $(21,22)$, in which xenograft tumors showed multiple lines of diffentiation. The present 
study reconfirms that multidirectional differentiation also occurs in the primary tumors.

Several mechanisms should be considered in explanation of the poorer prognosis of adenocarcinomas with endocrine features. Aggressive tumor behavior correlates with the level of differentiation in a tumor, which in turn could be a reflection of the (im)maturity of the tumor stem cell. Endocrine differentiation possibly represents a relatively immature celltype, as normal ECs preferentially occur basally in mucosal crypts, adjoining the stem cell region. Moreover, studies on renewal of ECs indicate that they might in part represent precursors for the other cell types (8), and transitions between ECs and mucin producing cells, so-called amphicrine cells, have been described (23). We previously demonstrated in the NCI-H716 cell line that endocrine and mucin producing cells are closely related and probably represent a relatively low level of differentiation (22). This cell line is derived from a poorly differentiated adenocarcinoma, and combines endocrine features, mucin production and amphicrine cells but lacks properties of columnar cells. In the present study on patient material, there was a significant correlation between endocrine differentiation and mucin production, indicating that these two cell lines indeed must be closely related in the differentiation pathway. On the other hand, there was no correlation between CGA and SC expression, whereas mucin production strongly correlated with SC immunoreactivity. It is tempting to speculate that mucin producing cells constitute an intermediate level of differentiation, which is reflected in the correlation between mucin production and CGA as well as SC expression, and also in the intermediate prognosis of tumors elaborating mucins (Fig. 5).

Growth stimulation by neurohormones might be an additional factor contributing to the infavorable prognosis of adenocarcinomas with ECs. It has been demonstrated that biogenic amines and polypeptide hormones play a role in growth regulation of normal and neoplastic intestinal epithelium (9). Expression of these molecules and of their receptors in cancer cells might constitute an autocrine growth promoting loop. We have indeed recently demonstrated appreciable levels of receptors for serotonin, somatostatin and gastrin on $\mathrm{NCl}-\mathrm{H} 716$ colon cancer cells (22). The fact that only tumors with numerous ECs show a tendency towards poorer prognosis indicates that the quantity of ECs is relevant, supporting the contention that secretion of neurohormonal substances by endocrine tumor cells could account for the poorer survival of tumors through autocrine or paracrine growth stimulation. Although the presence of numerous CGA positive tumor cells appears to be an independent prognostic variable, routine CGA staining of colorectal carcinoma is not warranted, because this finding as yet does not have any therapeutic implications. Nevertheless, ongoing research in this area is necessary, because this aspect of tumorgrowth potentially could lead to new therapeutic strategies. The hormone profile of ECs in colorectal tumors indicates that studies to this effect should be concentrated on the 
regulatory substances and their specific receptors which are indigenous to the large intestine. Finally, adenocarcinomas containing ECs appear to show a tendency for (early?) lymph node metastasis. Although there was no significant correlation with overall lymph node status, the strong correlation between ECs and central lymph node involvement points to the propensity of this type of rumor to disseminate rapidly, which obviously could contribute to a poorer prognosis. In summary, an appreciable number of CGA immunoreactive tumor cells distinguishes a group of colorectal adenocarcinomas with poorer prognosis. This more aggressive character reflects immaturity of the tumor stem cell or could result from auto- or paracrine growth stimulation by neurohormonal substances produced by endocrine tumor cells. 


\subsection{REFERENCES}

1. Chang WW, Leblond CP. A unitarian theory of the origin of the three populations of epithelial cells in the mouse large intestine. Anat Rec 1971;169:293.

2. Ho SB, Itzkowitz SH, Friera AM, Jiang S-H, Kim YS. Cell lineage markers in premalignant and malignant colonic mucosa. Gastroenterology 1989;97:392-404.

3. Bosman FT, De Bruine A. Endocrine cells in nonendocrine tumors of the gut and pancreas. In: Dayal Y ed, Endocrine pathology of the gut and pancreas. CRC Press, Boca Raton, Florida, 1991, pp.319-338.

4. Ooi A, Mai M, Ogino T, Ueda H, Kitamura T, Takahashi Y, Kawahara E, Nakanishi I. Endocrine differentiation of gastric adenocarcinoma. The prevalence as evaluated by immunoreactive chromogranin A and its biologic significance. Cancer 1988;62:10961104.

5. Cohen RJ, Glezerson G, Haffejee Z. Neuro-endocrine cells - A new prognostic parameter in prostate cancer. Br J Urol 1991;68:258-262.

6. Arends JW, Wiggers T, Verstijnen K, Bosman FT. The occurrence and clinicopathological significance of serotonin immunoreactive cells in large bowel carcinoma. J Pathol 1986;149:97-102.

7. Jansson D, Gould VE, Gooch GT, Rittenhouse HG, Shin SS, Manderino GL, Tomita JT, Staren ED. Immunohistochemical analysis of colon carcinomas applying exocrine and neuroendocrine markers. APMIS 1988;96:1129-1139.

8. De Bruïne AP. Dinjens WNM, Zijlema JHL, Lenders M-H, Bosman FT. Renewal of enterochromatitin cells in the rat caecum. Anat Rec 1992;233:75-82.

9. Johnson LR. Regulation of gastrointestinal mucosal growth. Physiol Rev 1988;68:456502.

10. Smith DM Jr, Haggitt RC. The prevalence and prognostic significance of argyrophil cells in colorectal carcinomas. Am J Surg Pathol 1984;8:123-128.

1 I. Wiedenmann B, Huttner WB. Synaptophysin and chromogranins/secretogranins - widespread constituents of distinct types of neuroendocrine vesicles and new tools in tumor diagnosis. Virchows Arch B Cell Pathol 1989;58:95-121.

12. Wiggers T, Jeekel J, Arends JW, Brinkhorst AP, Kluck HM, Luyk CI, Munting JDK, Povel JACM, Rutten APM, Volovics A, Greep JM. No-touch isolation technique in colon cancer: a controlled prospective trial. Br J Surg 1988;75:409-415.

13. Dukes CE. The classification of cancer of the rectum. J Pathol Bacteriol 1932;35:323332.

14. Blenkinsopp WK, Stewart-Brown S, Blesovsky L, Keamey G, Fielding LP. HistopathoIogic reporting in large bowel cancer. J Clin Pathol 1981;34:509-513.

15. Verstijnen CPHJ, Arends JW, Moerkerk PTM, Pijls M, Kuypers-Engelen B, Bosman FT. Colonic epithelium reactive monoclonal antibodies - Identification and immunohistochemical localization of target epitopes. Histochemistry 1989;92:397-406.

16. De Bruïne AP, Bosman FT. Neuroendocrine tumours of the respiratory tract. Acta Histochemica 1990;Suppl.-Band XXVII:99-105.

17. Pearse AGE. The cytochemistry and ultrastructure of polypeptide hormone-producing cells of the APUD series and the embryologic, physiologic and pathologic implications of the concept. J Histochem Cytochem 1969;17:303-313.

18. Iwashita A. Argyrophil and argentaffin cells in carcinomas of the colon and rectum. Fukuoka Acta Med 1979;70:370-390. 
19. Hamada Y, Oishi A, Shoji T, Takada H, Yamamura M, Hioki K, Yamamoto $M$. Endocrine cells and prognosis in patients with colorectal carcinoma. Cancer 1992;69:2641-2646.

20. Cox WF, Pierce GB. The endodermal origin of the endocrine cells of an adenocarcinoma of the colon of the rat. Cancer 1982;50:1530-1538.

21. Kirkland SC. Clonal origin of columnar, mucous, and endocrine cell lineages in human colorectal epithelium. Cancer 1988;61:1359-1363.

22 De Bruine AP, Dinjens WNM, Pijls MMJ, Van Der Linden EPM, Rousch MJM, Moerkerk PT, De Goeij AFPM, Bosman FT. NCI-H716 cells as a model for endocrine differentiation in colorectal cancer. Virchows Arch B Cell Pathol 1992;62:311-320.

23. Chejfec G, Capella C, Solcia E, Jao W, Gould VE. Amphicrine cells, dysplasias and neoplasias. Cancer 1985;56:2683-2690. 



\section{CHAPTER 8}

\section{GENERAL DISCUSSION}




\subsection{Introduction}

In this chapter the significance of endocrine differentiation in colorectal cancer is reviewed, with the intention to integrate data from clinical and fundamental research, regarding growth and differentiation of endocrine cells (ECs) in normal and neoplastic colorectal epithelium.

\subsection{Justification of the study and its design}

The development of the concept of the diffuse neuroendocrine (NE) system in the last decennia constitutes an important step forward in biology. In the evolution of this concept, the study of $\mathrm{NE}$ neoplasms has played a significant role. Although pure NE tumors are relatively uncommon, NE cells occur frequently in human neoplasms and therefore this phenomenon might be of potential clinical importance. In 1986 Arends et al. reported that colorectal adenocarcinomas containing serotonin immunoreactive endocrine tumor cells show a tendency towards poorer survival than tumors without this trait (1). At first sight, this appeared somewhat surprising, as one would be inclined to expect that tumors with the capacity for differentiation into supposedly mature ECs behave as well differentiated, less aggressive tumors. The present study was undertaken to shed more light on the biological and clinical significance of this observation. The working hypothesis was that colorectal adenocarcinomas with endocrine features are more aggressive, as a result of: 1) relative immaturity of the pluripotent tumor stem cell capable of endocrine differentiation and/or 2) autocrine/paracrine growth stimulation by neurohormones, produced and secreted by endocrine tumor cells. The clinical part of the study was executed because it was felt important to confirm the more aggressive behavior of colorectal adenocarcinomas with ECs. Although a clear tendency towards poorer survival emerged in the study of Arends et al, the data did not truly reach statistical significance in a five-year patient follow-up period. Moreover, endocrine features in the former study were defined by immunoreactivity for serotonin, which -although fairly commonly expressed by enteroendocrine cells- is not a genuine "pan-neuroendocrine" marker, and might only have identified a portion of endocrine differentiating tumors. Therefore, the study of Arends et al. was repeated, employing the superior general endocrine marker chromogranin A, with patient follow-up in the meantime extending over more than ten years. In addition, to appraise the level of cellular maturity of ECs, the correlation with other colorectal epithelial lineages in tumors was determined and the impact of the presence of the various cell lineages on tumor behavior was assessed. Finally, the hormone profile of endocrine tumor cells was established, to determine whether or not the neurohormones produced by endocrine 
tumor cells reflect the normal spectrum of colorectal neurohormones and to identify the neurohormones which might be of interest for the study of auto- or paracrine regulation of cellular growth in intestinal neoplasia.

An effort to clarify the biology of endocrine differentiation in normal and neoplastic epithelium was made in combining a study of turnover of ECs in normal colonic epithelium in the rat with studies on cell lines derived from human colorectal cancer. As colorectal cancer cell lines capable of endocrine differentiation turned out to be quite scarce, part of the in vitro studies consisted of the detailed descriptions of poorly and moderately well-differentiated cell lines, which might be used as models to study endocrine differentiation in colorectal cancer. Furthermore, studies with these cell lines were undertaken to identify factors which regulate the expression of the endocrine phenotype. Finally, the occurrence of various neurohormonal receptors on cancer cells was determined, and the presence of these receptors was correlated with effects of the pertinent neurohormones on tumor cell proliferation in vitro.

\subsection{ECs in non-endocrine tumors}

The occurrence of multiple lines of differentiation in a neoplasm is by no means new, but is encountered more often than in the past due to the availability of specific histotechnical methods in diagnostic pathology (2). The presence of ECs in primarily non-endocrine tumors is a striking example of this phenomenon and has been noted in a broad range of tumors (3). With the exception of composite tumors, in which a portion of the neoplasm shows an organoid pattern typical of a carcinoid tumor, the application of additional techniques is indispensable to identify endocrine features. Special care should be taken that the applied techniques are reliable and unequivocally demonstrate endocrine characteristics, because some histochemical methods, e.g. silver impregnation techniques, might stain non-endocrine cell components. Immunohistochemistry can lead to unwanted non-specific reactions as well (3). Therefore, the combination of more than one staining technique, accompanied by adequate controls and ideally supplemented with electron microscopy, is desirable for the demonstration of endocrine differentiation. Furthermore, the possibility should be excluded that the ECs are benign preexisting cells, entrapped by the invasively growing neoplasm. This possibility can be excluded when the tissue in which the tumor has originated does not normally contain ECs, when the ECs in the tumor are present in sufficiently large numbers and show cytonuclear features similar to surrounding tumor cells, and when the ECs are encountered in deeply invasive parts or metastases of the tumor. Once the occurrence of ECs in a non-endocrine tumor has been ascertained, several theories can be considered to explain this phenomenon. The first possibility is fusion of neoplastic cells with 
resident ECs, resulting in tumor cells retaining the endocrine phenotype of the benign cells. Although easy to induce in vitro, this has not definitively been demonstrated in vivo. Moreover, this theory is not tenable in cases where the tissue of origin does not normally contain ECs. Secondly, it can be argued that in neoplasms any type of differentiation can be encountered. Clearly, although aberrant differentiation does occur at times, most tumors demonstrate a differentiation potential, restricted to the cell types normally occurring in the tissue of origin (2). Thirdly, the occurrence of multiple lines of differentiation in a tumor might be explained in postulating a polyclonal origin of the neoplasm. However, as the weight of the evidence presently is in favor of the concept that tumors are monoclonal, the most likely explanation seems to be multipotentiality of the tumor stem cell (4).

\subsection{Clinical significance of ECs in colorectal cancer}

The phenomenon of multiple lines of differentiation in a tumor, though interesting from a biological point of view, would gain even more interest if it would also have a bearing on tumor behavior. It is evident that the cellular phenotype in a tumor has a bearing on tumor behavior, as reflected in the growth rate, in the propensity for invasion and metastasis, or in the response to therapy. In this respect, ECs in a non-endocrine tumor could particularly be of clinical interest, because endocrine tumor cells can elaborate bioactive substances such as amines and peptide hormones. Secretion of these substances could lead to symptoms of hormone overproduction or could be applied as a marker for tumor progression or recurrence. However, manifest hormone production by endocrine tumor cells in colorectal cancer does not occur and is of no importance in the clinical presentation of tumors containing ECs (5). In addition to the carcinoid tumor, endocrine differentiation in colorectal cancer can appear in different forms, covering a spectrum ranging from predominantly endocrine tumors, via combined exo- and endocrine tumors of varying differentiation, to classical tubulopapillary adenocarcinomas with scattered ECs (5). In the present study, we concentrated on light microscopically classified adenocarcinomas containing scattered ECs. Adenocarcinomas are the most prevalent type of tumor in the large intestine, and a perceptible effect of endocrine differentiation on tumor prognosis in this category would be most significant from a clinical point of view. Systematic search for ECs occurring in colorectal adenocarcinomas has not been frequently performed. Previously published studies regarding prognosis of colorectal tumors containing a subpopulation of ECs yielded conflicting results $(1,6)$. The systematic search for ECs in two large series of colorectal adenocarcinomas by Hamada et al. (7) and by our own group (8), has generated compelling evidence that colorectal adenocarcinomas with significant numbers 
of ECs are indeed more aggressive than those lacking ECs. Moreover, the presence of endocrine characteristics identifies subsets of tumors within Dukes' $\mathrm{B}$ or $\mathrm{C}$ stages differing in survival.

\subsection{Biological significance of ECs in colorectal cancer}

These studies touch upon three aspects of the biology of endocrine differentiation in colorectal cancer: the factors determining the appearance of ECs in carcinomas, renewal of gut endocrine cells, and the regulation of colorectal cancer growth by amines and peptides.

\subsubsection{Regulation of endocrine differentiation}

Embryological studies have shown that contact between endoderm and mesoderm is instrumental in the development of the correct intestinal endocrine population (9). The basal side of ECs in normal crypt epithelium is in direct contact with the pericryptal basement membrane (10). In neoplasia, EC $\mathrm{s}$ in general are located peripherally in tumor lobules, in contact with surrounding stroma (8). In colorectal cancer cell lines, ECs, when present, mainly occur in xenografts, where stromal factors are present (11). Taken together, these observations suggest that extracellular matrix (ECM) might be an essential regulator of endocrine differentiation. This hypothesis was tested in detail in the cell line $\mathrm{NCl}-\mathrm{H} 716$, derived from ascitic fluid of a patient with a poorly differentiated caecal adenocarcinoma displaying endocrine features. These results confirm a significant role of ECM components in the upregulation of endocrine differentiation, as was demonstrated by increased expression of chromogranin $A$ at both the transcriptional and protein level. As to the mechanisms involved, two elements were identified: integrin receptor mediated attachment of epithelial cells to mesenchymal structures, and ECM mediated modulation of differentiation induction by growth factors (12). That this mechanism is not universally applicable follows from the in vitro studies with the moderately well-differentiated cell line Caco-2 and its point mutated c-Ha-Ras-transfected subline Caco$2 \mathrm{EJ} 6$. In both these cell lines, ECs were exclusively encountered in vivo in nude mice xenografts, but attempts to induce endocrine differentiation in vitro remained unsuccesful (13). Despite this discrepancy, the predominant presence of ECs at the epithelial-stromal interface in xenografts of Caco-2 cells and in primary colorectal adenocarcinomas, supports a role for ECM in the development of the endocrine phenotype. The precise mechanism involved might differ from case to case, and perhaps depends on the level of maturity of the tumor stem cells. The experiments with the Ras-transfected Caco-2 EJ6 cells demonstrate that, contrary to suggestions based on studies on medullary thyroid 
carcinoma (14) and small cell carcinoma of the lung (15), Ras overexpression does not induce endocrine differentiation.

\subsubsection{Renewal of gut ECs}

Our study on the kinetics of ECs in the rat was performed because knowledge of kinetics of ECs in the digestive tract may contribute to a better understanding of intestinal mucosal growth and differentiation in both normal and pathologic circumstances. To study the biology of ECs, ideally, one would like to follow an individual EC during its lifetime, which is not feasible. As an alternative, a study of the entire population of ECs, by combined pulse-chase and continuous labeling with the thymidine analogue $\mathrm{BrdU}$, was performed (16).

The questions addressed in these experiments were how the renewal of ECs takes place and whether or not ECs are capable of proliferation. We found ECs indeed capable of proliferation. In this respect they resemble the other epithelial lineages, although turnover and migration are considerably slower (17). In addition to self-replication, the EC population remains in a steady state by recruitment from proliferating precursor cells. It appeared that the population of enterochromaffin cells in rat caecal epithelium, representing the vast majority of ECs, consists of two kinetically distinct subpopulations, one with a relatively rapid turnover, and one with slower renewal. A difference in migratory properties and distribution over the crypt emerged: the slowly renewing population appeared to be stationary and evenly distributed over the upper and lower crypt segments, whereas the relatively rapidly renewing fraction, which accounted for the ECs in the crypt base, was subject to upward migration. It is tempting to speculate that the migrating population might be an epithelial derivative, and the stationary fraction might have a neural origin, each category with a different precursor cell. This hypothesis might revitalize one aspect of the original APUD hypothesis (18): the neuroectodermal origin of (a subpopulation of) ECs in the gut. The existence of two subpopulations of ECs has been suggested previously, in kinetic studies (19) as well as in studies on the secretory activity of enterochromaffin cells (20). Further studies on morphology and function of these two subpopulations are warranted, to investigate the validity of this compelling hypothesis.

ECs in normal intestinal epithelium are preferentially localized in the basal parts of the crypts of Lieberkühn (21). In a continuously renewing and upward migrating crypt cell population, one would expect an even distribution of ECs along the crypt. The preferentially basal location of ECs can theoretically be explained by 1) lack of migration of crypt base derived ECs and 2) cell loss during migration. The former is difficult to envision in view of our own results and because ECs are integrated elements in a continuously moving sheet and their shedding from the mucosal surface has been observed (22). The second possibility could result from the transition of ECs into other epithelial cell types. 
This possibility is supported by descriptions of combined endo- and exocrine cells, so-called "amphicrine" cells (23). Thus, ECs in the crypt base would represent a temporary phase in intestinal epithelial differentiation and would in part be precursor cells for other cell lineages. This hypothesis suggests that a hierarchy exists in the maturity of the various cell types, increasing from ECs and mucin producing cells to columnar cells. In normal intestinal epithelium, which is continuously renewed from the crypt base upwards, the distribution of the three cell types, with ECs mainly in a basal position, mucin producing goblet cells along the crypt length, and columnar cells dominating the surface epithelium, fits this model (21). Further circumstantial evidence in favor of this hypothesis is derived from our studies on endocrine differentiation in primary colorectal carcinomas. A significant correlation was found between the occurrence of endocrine cells and of mucin producing cells, and also of mucin producing and columnar cells. In contrast, no correlation was found between the occurrence of endocrine ceils and of columnar cells. The hierarchy in maturity of these three cell types fits differences in the prognosis of tumors expressing these traits: the occurrence of endocrine differentiation corresponded with shortest survival, carcinomas with mucin production had an intermediate position and those with columnar cell features showed the longest survival (8). Taken together these observations suggest that ECs in intestinal epithelium maturate. ECs derived from committed precursor cells and located in the basal zone of mucosal crypts are relatively immature. They subsequently develop into mature, terminally differentiated ECs in upper crypt segments or surface epithelium or give rise to higher differentiated cells of another type. The spectrum of endocrine differentiation in colorectal cancer also fits this concept: small cell NE carcinomas reflect immature ECs, carcinoids reflect mature ECs and combined endoand exocrine tumors reflect the transition between ECs and other cell types.

\subsubsection{Neurohormonal regulation of cancer cell growth}

A considerable body of evidence indicates that amines and polypeptide hormones elaborated by ECs in the gut can act as growth regulating factors, either stimulating or inhibiting growth of intestinal epithelium in normal, adaptive and neoplastic conditions. However, some contradictory results have been published, partly due to varying experimental conditions (24-27). An unresolved question is whether neurohormones act locally, as paracrine or autocrine signal molecules, or as circulating hormones. Both possibilities in principle could apply to substances like gastrin, serotonin, bombesin/GRP and enteroglucagon $(28,29)$. Somatostatin more likely acts locally, as it is rapidly metabolized $(30)$. Although the presence of specific neurohormonal receptors on cells is required in order to attain an effect on cell growth, receptor expression has been rarely studied in connection with growth regulation. Animal models and preferably patient trials will be necessary to definitively settle the issue as to whether or not 
modulation of colorectal cancer growth by neurohormones does occur. Promising results have been achieved in some animal models (31). Patient studies are scarce and a significant benefit has not been proven as yet (32). In an attempt to resolve some of these discrepancies, we chose to study four non-endocrine cell lines reported to be responsive to neurohormonal manipulation $(25-27,33)$ and NCI-H7 6 cells, a cell line with NE features (34). We measured the presence of membrane receptors for gastrin, serotonin and somatostatin in these cells, and correlated the results with the observed effects of the corresponding ligands on cell growth. Of the five cell lines studied, only NCI-H716 cells expressed specific high affinity binding sites for all three substances and were also sensitive to growth regulation by these ligands. The most significant effect was growth inhibition by octreotide, a somatostatin analogue, due to slower traversing of the cell cycle. As somatostatin itself did not effect the rate of proliferation, octreotide presumably acts via a somatostatin receptor (SSTR) subtype. Effects of octreotide on tumor growth also involve other mechanisms, because this compound was also shown to induce apoptosis in tumor cells (35). SSTRs were found in all cell lines studied, including Caco-2 cells, in agreement with studies on SSTRs in colorectal tumors (36,37). Taken together, the results show that proliferation occurs only when receptors are expressed. However, receptor expression does not always correspond with a response of the receptor bearing cell in terms of altered proliferation rate.

We conclude that: 1) Cell proliferation in colorectal cancer may be modulated by neurohormonal peptides through specific receptors. 2) The presence of these receptors appears to be a prerequisite for growth modulation but does not necessarily imply that modulation of proliferation will be found. 3) Whether or not neurohormonal peptides are responsible for the prognostic significance of ECs in colorectal carcinomas remains to be established. 4) The hormone profile of ECs in colorectal adenocarcinomas corresponds with that of normal colorectal epithelium, and therefore studies on autocrine/paracrine growth regulation should focus on hormones and amines indigenous to the large intestine. 5) Somatostatin and its analogues could be promising as a growth inhibitor in colorectal adenocarcinomas, especially those with endocrine features.

\subsection{Future perspectives}

Further exploration of the underlying cause(s) of the poorer survival of colorectal adenocarcinomas with endocrine differentiation is warranted because more knowledge on the biology of this phenomenon might lead to the development of new therapeutic strategies. Future studies on the biology of endocrine differentiation could be directed at: 
1) Clarification of the biological significance of the heterogeneity with regard to cell renewal of ECs. Ultrastructural investigations might be included in this field.

2) Further unraveling of the mechanisms by which extracellular matrix induces endocrine differentiation. The nature of the contacts between epithelium and extracellular matrix and amongst epithelial cells might be further elucidated. Furthermore, paracrine factors which induce differentiation in epithelial or stromal cells might be studied by molecular biological techniques, in combination with antibodies or antagonists to such factors and their receptors.

3) Resolution of the role of biogenic amines and polypeptide hormones in growth modulation of colorectal tumors containing ECs, focussing on receptor assays and determination of proliferation modulating effects of the ligands. Receptor studies ideally should include histochemical visualization of receptors, which would yield information on heterogeneity of receptor expression within tumors. Cell kinetic analysis might lead to a better understanding of the mechanisms of growth modulation by neurohormones, which could lead to rational use of these substances. Futhermore, in vitro studies might be extended to animal studies and patient trials. 


\subsection{REFERENCES}

1. Arends JW, Wiggers T, Verstijnen C, Bosman FT, The occurrence and clinicopathological significance of serotonin immunoreactive cells in large bowel carcinoma. J Pathol 1986;149:97-102.

2. Mendelsohn G, Maksem JA. Divergent differentiation in neoplasms. Pathologic, biologic and clinical considerations. Pathol Annu 1986;21:91-119.

3. Bosman FT. Neuroendocrine cells in non-neuroendocrine tumours. In: Evolution and Tumour Pathology of the Neuroendocrine System. Falkmer S, Håkanson R, Sundler F eds, Elsevier, Amsterdam New York Oxford, 1984, pp.519-543.

4. Cox WF, Pierce GB. The endodermal origin of the endocrine cells of an adenocarcinoma of the colon of the rat. Cancer 1982;50:1530-1538.

5. Bosman FT, De Bruine A. Endocrine cells in nonendocrine tumors of the gut and pancreas. In: Endocrine Pathology of the Gut and Pancreas. Dayal Y ed, CRC Press, Boca Raton, Florida, 1991, pp.319-338.

6. Smith DM, Haggitt RC. The prevalence and prognostic significance of argyrophil cells in colorectal carcinomas. Am J Surg Pathol 1984;8:123-128.

7. Hamada Y, Oishi A, Shoji T, Takada H, Yamamura M, Hioki K, Yamamoto M. Endocrine cells and prognosis in patients with colorectal carcinoma. Cancer 1992;69:2641-2646.

8. De Brü̈ne AP, Wiggers Th, Beek C, Volovics A, Von Meyenfeldt M, Arends JW, Bosman FT. Endocrine cells in colorectal adenocarcinomas: incidence, hormone profile and prognostic relevance. Int J Cancer 1993; in press.

9. Stein B, Andrew A. Differentiation of endocrine cells in chick allantoic epithelium combined with pancreatic mesenchyme. Cell Differ Dev 1989;26:173-180.

10. Sjölund K, Sandén G, Håkanson R, Sundler F. Endocrine cells in human intestine: an immunocytochemical study. Gastroenterology 1983;85:1120-1130.

11. Del Buono R, Pignatelli M, Hall PA. Control of differentiation in a rectal adenocarcinoma cell line: the role of diffusable and cell-associated factors. J Pathol 1991;164:5966.

12. De Bruïne AP, Dinjens WNM, Van der Linden EPM, Pijls MMJ, Moerkerk PT, Bosman FT. Extracellular matrix components induce endocrine differentiation in vitro in $\mathrm{NCl}$ H7 16 cells. Am J Pathol 1993; 142:773-782.

13. De Bruïne AP, De Vries JE, Dinjens WNM, Moerkerk PT, Van der Linden EPM, Pijls MMJ, Ten Kate J, Bosman FT. Human Caco-2 cells transfected with c-Ha-Ras as a model for endocrine differentiation in the large intestine. Differentiation 1993;53:51-60.

14. Nakagawa T, Mabry M, De Bustros A, Ihle JN, Nelkin BD, Baylin SB. Introduction of $\mathrm{v}$-Ha-ras oncogene induces differentiation of cultured human medullary thyroid carcinoma cells. Proc Nat Adad Sci USA 1987;84:5923-5927.

15. Mabry M, Nakagawa T, Baylin S, Pettengill $O$, Sorenson G, Nelkin B. Insertion of the $\mathrm{v}$-Ha-ras oncogene induces differentiation of calcitonin-producing human small cell lung cancer. J Clin Invest 1989;84:194-199.

16. De Bruine AP, Dinjens WNM, Zijlema JHL, Lenders M-H, Bosman FT. Renewal of enterochromaffin cells in the rat caecum. Anat Rec 1992;233:75-82.

17. Lipkin M. Proliferation and differentiation of nomal and diseased gastrointestinal cells. In: Physiology of the Gastrointestinal Tract, 2nd edition. Johnson LR ed, Raven Press, New York, 1987, pp.255-284. 
18. Pearse AGE. The cytochemistry and ultrastructure of polypeptide hormone-producing cells of the APUD series and the embryologic, physiologic and pathologic implications of the concept. J Histochem Cytochem 1969;17:303-313.

19. Chang WWL, Leblond CP. Renewal of the epithelium in the descending colon of the mouse. II Renewal of argentaffin cells. Am J Anat 1971;131:101-110.

20. Simon C, Ternaux JP. Regulation of serotonin release from enterochromaffin cells of rat cecum mucosa. J Pharmacol Exp Ther 1990;253:825-832.

21. Hamilton SR. Strucure of the colon. Scand J Gastroenterol 1984: 19(Supp.93):13-23.

22. Baron DA, Miller DB. Extrusion of colonic epithelial cells in vitro. J Electron Microsc Tech 1990;16:15-24.

23. Ratzenhofer M. Hyperplasias and tumors of the disseminated endocrine (paracrine) Helle Zellen Feyrter's of the gut with special regard of amphicrine cell proliferations. In: Verh Dtsch Ges Pathol 61 Tagg Erlangen, Gustav Fischer, Stuttgart New York, 1977, pp.7-24.

24. Johnson LR. Regulation of gastrointestinal growth. In: Physiology of the Gastrointestinal Tract, 2nd edition. Johnson LR ed, Raven Press, New York, 1987, pp.301-333.

25. Kusyk CJ, McNiel NO, Johnson LR. Stimulation of growth of a colon cancer cell line by gastrin. Am J Physiol 1986;251:G597-601.

26. Watson SA, Durrant LG, Morris DL. Growth-promoting action of gastrin on human colonic and gastric tumor cells cultured in vitro. Br J Surg 1988;75:342-345.

27. Watson S, Durrant L, Morris D. Gastrin: growth enhancing effects on human gastric and colonic tumour cells. Br J Cancer 1989;59:554-558.

28. Singh P, Le S, Beauchamp RD, Townsend CM, Thompson JC. Inhibition of pentagastrin-stimulated up-regulation of gastrin receptors and growth of mouse colon tumor in vivo by proglumide, a gastrin receptor antagonist. Cancer Res 1987;47:5000-5004.

29. Hoosein NM, Kiener PA, Curry RC, Brattain MG. Evidence for autocrine growth stimulation of cultured colon tumor cells by a gastrin/cholecystok inin-like peptide. Exp Cell Res 1990; 186:15-21.

30. Seal A, Yamada T, Debas H, Hollinshead J, Osadchey B, Aponte G, Walsh J. Somatostatin-14 and -28 clearance and potency on gastric function in dogs. Am J Physiol 1982;243:G97-G102.

31. Qin Y, Schally AV, Willems G. Treatment of liver metastases of human colon cancers in nude mice with somatostatin analogue RC-160. Int J Cancer 1992;52:791-796.

32. Morris DL, Charnley RM, Ballantyne KC, Jones J. A pilot randomized control trial of proglumide (a gastrin receptor antagonist) in advanced colorectal cancer. Eur J Surg Oncol 1990;16:423-425.

33. Imdahl A, Eggstein S, Crone C, Farthmann EH. Growth of colorectal carcinoma cells: regulation in vitro by gastrin, pentagastrin and the gastrin-receptor antagonist proglumide. J Cancer Res Clin Oncol 1989;115:388-392.

34. De Bruïne AP, Dinjens WNM, Pijls MMJ, Van der Linden EPM, Rousch MJM, Moerkerk PT, De Goeij AFPM, Bosman FT. NCI-H716 cells as a model for endocrine differentiation in colorectal cancer. Virchows Arch B Cell Pathol 1992;62:311-320.

35. Pagliacci MC, Tognellini $R$, Grignani F, Nicoletti I. Inhibition of human breasit cancer cell (MCF-7) growth in vitro by the somatostatin analog SMS 201-995: effects on cell cycle parameters and apoptotic cell death. Endocrinology 1991;129:2555-2562.

36. Radulovic SS, Milovanovic SR, Cai RZ, Schally AV. The binding of bombesin and somatostatin and their analogs to human colon cancers. Proc Soc Exp Biol Med 1992;200:394-401. 
37. Lamberts SWJ, Krenning EP, Reubi J-C. The role of somatostatin and its analogs in the diagnosis and treatment of tumors. Endocrine Rev 199|;12:450-482. 


\section{SUMMARY}

\section{Chapter 1}

This chapter comprises a general introduction to the field of study and describes the aims of the study.

\section{Chapter 2}

The localization, morphology and neurohormonal peptide content of neuroendocrine cells have been extensively investigated. Relatively little is known about the kinetics of growth and differentiation of these cells. In this chapter, we studied the kinetics of enterochromaffin (EC) cells in the caecum of the rat, by applying the thymidine analogue 5-bromo-2'-deoxyuridine (BrdU), to identify S-phase cells, administered in pulse-chase and synchronous continuous labeling experiments. By double indirect immunofluorescence staining of tissue sections, using antibodies against serotonin and BrdU, percentages of BrdU positive EC cells could be enumerated, from which cell-kinetic parameters were derived. The following conclusions were drawn:

1) EC cells are renewed by proliferation of EC cells and by recruitment from proliferating precursor cells.

2) Caecal EC cells appear to consist of a relatively rapidly renewing and migrating fraction (60-65\%) with a turnover time of approximately 16 days and a relatively slowly renewing and possibly stationary fraction (35-40\%) with an estimated turnover time of approximately 150 days.

3) $70 \%$ of the EC cells is localized in the lower half of mucosal crypts, $30 \%$ in the upper half. After prolonged labeling the percentage of labeled EC cells in the lower crypt half always exceeds that in the upper crypt half. This decrease in labeled EC cells during migration towards the mucosal surface indicates loss of endocrine cells, possibly owing to loss of endocrine characteristics. 


\section{Chapter 3}

In colonic neoplasms, endocrine differentiation is encountered not only in carcinoid tumors but also in adenocarcinomas, where endocrine cells may represent a distinct line of differentiation of the tumor. Endocrine cells occur in $\pm 30 \%$ of colorectal adenocarcinomas. The significance of endocrine differentiation in colorectal cancer is not well established, partly because of the paucity of tumor cell lines which can serve as a model to study endocrine differentiation. In this chapter we describe the properties of NCI-H716 cells, a cell line derived from a poorly differentiated adenocarcinoma of the caecum, under various in vitro conditions and as xenografts in athymic mice. Phenotypical properties were immunohistochemically assessed using a panel of differentiation related antibodies, and furthermore by Northern blot analysis and by electron microscopy. Receptors for biogenic amines and peptide hormones were analyzed by ligand binding assay. These studies show that: 1 . NCI-H716 cells can be undifferentiated, but also endocrine, mucin-producing or "amphicrine". 2. Endocrine differentiation of NCI-H716 cells preferentially occurs in xenografts in athymic mice, which suggests that mesenchymal elements induce endocrine differentiation. 3. NCI-H716 cells express large amounts of high affinity receptors for gastrin, serotonin and somatostatin and these substances can regulate growth. Therefore, NCI-H716 cells form a suitable model for the study of endocrine differentiation in intestinal epithelium and of auto- or paracrine growth regulation in intestinal neoplasia.

\section{Chapter 4}

Endocrine differentiation in colorectal cancer cell lines is almost confined to tumor xenografts in vivo, suggesting that endocrine differentiation might be regulated by epithelial-stromal interactions. In this chapter this hypothesis was studied in the caecal adenocarcinoma derived cell line NCI-H716, by comparing the expression of chromogranin A (CGA) protein and $\mathrm{mRNA}$ in vivo and in vitro, and by attempts to induce differentiation in vitro. We found that CGA expression, which was strongest in vivo, could be significantly enhanced in vitro by culturing tumor cells in the presence of native extracellular matrix (ECM), on fibroblast feeder layers and in defined medium with basic fibroblast growth factor (bFGF). The results suggest that ECM induces endocrine differentiation through factors (e.g. bFGF) which may be produced by stromal cells and after secretion bind to the ECM. 


\section{Chapter 5}

To study the factors regulating endocrine differentiation in colorectal cancer, which may bear resemblance to the regulation of endocrine differentiation in normal intestinal mucosa, additional models in which differentiation can be manipulated are essential. Ideally, such models should resemble the differentiation spectrum of normal colorectal epithelium. In this chapter we attempted to demonstrate endocrine differentiation in the colonic adenocarcinoma cell line Caco-2, which is frequently used as a model for enterocytic differentiation. In vitro endocrine tumor cells were not encountered. In vivo studies were cumbersome, because of the low take rate of Caco- 2 cells. We did manage to establish nude mouse xenografts of Caco-2 cells by inoculating cells in collagen gel and by suppressing natural killer cell activity. In an attempt to induce a better take rate and to investigate the effect of Ras oncoprotein overexpression on endocrine differentiation, Caco-2 cells were transfected with a point mutated c-Ha-Ras gene. The cell line Caco-2 EJ6, generated from these experiments, could be xenografted in nude mice with a high take rate, yielding a moderately well differentiated adenocarcinoma, morphologically identical to the tumors derived from untransfected Caco- 2 cells. The xenografts displayed goblet cell, enterocytic, Paneth cell and endocrine differentiation. In vitro endocrine differentiation was not observed, neither under standard conditions nor with extracellular matrix components as differentiation inducers.

We conclude that the Caco-2 cell line and its c-Ha-Ras transfected subline Caco-2 EJ6 in vivo display endocrine differentiation. Ras overexpression does not enhance endocrine differentiation. Due to its favorable growth properties in vivo, Caco-2 EJ6 is a suitable model for studies on endocrine differentiation in colorectal cancer.

\section{Chapter 6}

In this chapter, the presence of receptors was correlated with the effect of the neurohormones gastrin, serotonin and somatostatin on the proliferation and cell kinetics of five colon cancer cell lines. Receptors were determined by radioligand binding assay on HT 29, LoVo, LS 174T, SW 403 and NCI-H716 cells. Gastrin receptors were found in LS 174 T, SW 403 and NCI-H716 cells. Serotonin receptors were detected in SW 403 and NCI-H716 cells. Receptors for somatostatin were demonstrated in the five cell lines tested. In competition experiments it was shown that the gastrin antagonist CAM 958, the serotonin antagonist methysergide, and the somatostatin analogue octreotide interacted with receptor binding sites for gastrin, serotonin and somatostatin, respectively. 
The proliferative response of the colon cancer cell lines to gastrin, serotonin and somatostatin was measured by $\left[{ }^{3} \mathrm{H}\right]$-thymidine incorporation. Various culturing conditions were used, including the incubation of the cells in the presence of $0 \%$, $1 \%$ dialyzed and $10 \%$ complete fetal bovine serum, and synchronization of the cells. Only the neuroendocrine NCI-H716 cells were modulated in proliferative activity by nanomolar concentrations of gastrin and serotonin. The stimulatory effect only occurred under conditions of growth restriction. Somatostatin had no effect on the proliferation of $\mathrm{NCI}-\mathrm{H} 716$ cells.

The effect of receptor ligands on cell kinetics of NCI-H716 cells was studied by dual parameter flow cytometric analysis after pulse labeling with bromodeoxyuridine. Gastrin did not induce significant changes in NCI-H716 cell kinetics. The gastrin antagonist CAM 958 had a small inhibiting effect on proliferation of NCI-H7 16 cells. Serotonin inhibited with borderline significance and methysergide did not influence the proliferative activity. Whereas somatostatin had no effect, octreotide significantly increased the potential doubling time of NCI$\mathrm{H} 716$ cells, without changes in labeling index. This indicates that no specific blocks occur in the $G_{0} / G_{1}$ phase, but that the overall traverse of the cells through the cell cycle is slowed down.

The presence of receptors for neurohormones does not guarantee a proliferative response of colon cancer cells in vitro. The results suggest that growth modulating effects of neurohormones are receptor-mediated and might be predominantly confined to colorectal adenocarcinomas with neuroendocrine characteristics. Furthermore, somatostatin analogues could be effective as growth inhibitors for these tumor cells.

\section{Chapter 7}

In this chapter the clinical relevance of endocrine differentiation in colorectal cancer is examined. The occurrence of endocrine cells in 350 cases of colorectal adenocarcinoma was studied by immunohistochemistry for chromogranin $\mathrm{A}$ (CGA). The hormone profile of endocrine tumor cells, the correlation between endocrine differentiation and presence of other colorectal epithelial cell lineages and the prognostic relevance of endocrine differentiation in colorectal cancer were investigated. CGA positive tumor cells were found in $30 \%$ of cases, $21 \%$ showing moderate positivity $\left(<1 \mathrm{cell} / \mathrm{mm}^{2}\right)$, and $9.0 \%$ extensive positivity $(>1$ $\mathrm{cell} / \mathrm{mm}^{2}$ ). Of CGA positive tumors $70 \%$ additionally produced neurohormones, mainly indigenous to normal colorectal epithelium: $55 \%$ showed immunoreactivity for glucagon-like substances, $20 \%$ for serotonin and $10 \%$ for somatostatin, PYY and HCG. No immunoreactivity was found for various neurohormones not normally produced by colorectal endocrine cells. CGA positive tumors tended to be more aggressive than CGA negative tumors ( $\mathrm{p}=0.068$ ). Especially tumors 
with extensive CGA positivity showed shorter survival, which was most apparent within Dukes' $C$ stage $(\mathrm{p}=0.028)$. In multivariate analysis, extensive CGA positivity was an independent indicator of poor prognosis $(\mathrm{p}=0.015)$. CGA immunoreactivity significantly correlated with mucin production, but not with expression of secretory component (SC), a columnar cell marker. Mucin production significantly correlated with SC expression. Tumors positive for CGA but not for mucin and/or $\mathrm{SC}$ showed the worst prognosis $(\mathrm{p}<0.001)$. SC expression was a relatively favorable feature, and mucin producing tumors showed intermediate behavior.

\section{Chapter 8}

This chapter embodies the general discussion of the biological and clinical relevance of endocrine differentiation in colorectal cancer, integrating data from clinical and fundamental research presented in previous chapters. 



\section{SAMENVATTING}

\section{Hoofdstuk 1}

Dit hoofdstuk bevat een algemene introductie tot het onderwerp van studie en zet de doelstellingen van deze studie uiteen.

\section{Hoofdstuk 2}

De localisatie, morfologie en het neurohormonale peptide gehalte van neuroendocriene cellen zijn uitgebreid onderzocht. Relatief weinig is bekend over groei en differentiatie van deze cellen. In dit hoofdstuk hebben wij de celkinetiek van enterochromaffiene (EC) cellen in het coecum van de rat onderzocht, door toediening van het thymidine analogon 5-bromo-2'-deoxyuridine (BrdU), ter identificatie van cellen in de $S$-fase van de celcyclus, in synchrone pulse-chase en continu labeling experimenten. Door middel van een dubbele indirecte immuunfluorescentie kleuring op weefselcoupes, gebruik makend van antilichamen tegen serotonine en BrdU, konden percentages van BrdU positieve EC cellen bepaald worden, waarvan celkinetische parameters werden afgeleid. Dit heeft geleid tot de volgende conclusies:

1) Aanmaak van nieuwe EC cellen vindt plaats door proliferatie van EC cellen zelf en door recrutering uit prolifererende voorloper cellen.

2) EC cellen in het coecum van de rat blijken te bestaan uit een relatief snel vernieuwende en migrerende fractie (60-65\%) met een levensduur van circa 16 dagen en een relatief langzaam vernieuwende en mogelijk niet migrerende fractie (35-40\%) met een geschatte levensduur van circa 150 dagen.

3) $70 \%$ van de EC cellen bevindt zich in de onderste helft van de slijmvlies crypten, $30 \%$ in de bovenste helft. $\mathrm{Na}$ langdurige toediening van $\mathrm{BrdU}$ is het percentage BrdU-gelabelde cellen in de onderste crypt helft altijd groter dan in de bovenste crypt helft. Deze afname van gelabelde EC cellen gedurende migratie naar het mucosale oppervlak wijst op verlies van endocriene cellen, mogelijk door verlies van endocriene kenmerken. 
positieve tumoren produceerde $70 \%$ additionele neurohormonen, thuishorend in normaal dikke darmepitheel: $55 \%$ toonde immunoreactiviteit voor glucagonachtige substanties, $20 \%$ voor serotonine en $10 \%$ voor somatostatine, PYY en HCG. Er werd geen immunoreactiviteit gevonden voor diverse neurohormonen die normaliter niet geproduceerd worden door endocriene cellen in de dikke darm. CGA positieve tumoren neigden tot aggressiever gedrag dan CGA negatieve tumoren ( $\mathrm{p}=0.068$ ). Vooral tumoren met sterke CGA positiviteit toonden een kortere overlevingsduur, hetgeen het meest uitgesproken was in Dukes' $\mathrm{C}$ stadium ( $p=0.028$ ). In multivariaat analyse, was sterke CGA positiviteit een onafhankelijke indicator van een slechte prognose $(p=0.015)$. CGA immunoreactiviteit correleerde significant met slijm produktie, maar niet met expressie van secretoir component (SC), een marker voor columnaire cellen. Slijm produktie correleerde significant met SC expressie. Tumoren die positief waren voor CGA maar niet voor slijm en/of SC hadden de slechtste prognose $(p<0.001)$. SC expressie was een relatief gunstig kenmerk, en slijm producerende tumoren gedroegen zich intermediair.

\section{Hoofdstuk 8}

Dit hoofdstuk omvat de algemene discussie over de biologische en klinische relevantie van endocriene differentiatie in dikke darmkanker, en integreert hierbij gegevens van klinisch en fundamenteel onderzoek zoals gepresenteerd in voorgaande hoofdstukken. 


\section{Hoofdstuk 5}

Om de factoren te bestuderen die endocriene differentiatie in dikke darm kanker reguleren, en die gelijkenis zouden kunnen tonen met de regulatie van endocriene differentiatie in normaal darmslijmvlies, zijn additionele modellen waarin differentiatie gemanipuleerd kan worden van groot belang. Idealiter zouden dergelijke modellen overeen moeten komen met het differentiatie spectrum in normaal dikke darm epitheel. In dit hoofdstuk hebben we gepoogd om endocriene differentiatie aan te tonen in de van een adenocarcinoma van het colon afgeleide cellijn Caco-2, die dikwijls gebruikt wordt als model voor enterocytaire differentiatie. In vitro werden geen endocriene tumorcellen gevonden. In vivo studies waren moeizaam, vanwege het geringe succes bij de produktie van tumor xenografts. Wij zijn er wel in geslaagd om xenografts van Caco- 2 cellen in naakte muizen te produceren door cellen te implanteren in collageen gels en door natural killer cell activiteit te onderdrukken. Om het succes van xenograften te vergroten en het effect van Ras oncoproteine overexpressie op endocriene differentiatie te bestuderen, werden Caco- 2 cellen getransfecteerd met een puntgemuteerd c-Ha-Ras gen. De cellijn Caco-2 EJ6, die bij deze proeven ontstond, kon succesvol geimplanteerd worden in naakte muizen, resulterend in een matig gedifferentieerd adenocarcinoom, morfologisch identiek aan de tumoren die ontstonden uit niet-getransfecteerde Caco-2 cellen. De tumor xenografts toonden slijmbekercel-, enterocytaire-, Paneth cel- en endocriene differentiatie. In kweek werd endocriene differentiatie noch onder standaard condities, noch in het bijzijn van extracellulaire matrix componenten gevonden. We concluderen dat de cellijn Caco-2 en de c-Ha-Ras getransfecteerde sublijn Caco-2 EJ6 in vivo endocriene differentiatie tonen. Ras overexpressie doet endocriene differentiatie niet toenemen. Dankzij de gunstige groeieigenschappen in vivo, is Caco-2 EJ6 een geschikt model voor het bestuderen van endocriene differentiatie in colorectale tumoren.

\section{Hoofdstuk 6}

In dit hoofdstuk werd de aanwezigheid van receptoren voor gastrine, serotonine en somatostatine in de colon carcinoom cellijnen HT 29, LS 174T, LoVo, SW 403 en NCl-H716 gecorreleerd met de effecten van deze neurohormonen op proliferatie van de tumorcellen. Neurohormonale receptoren werden bepaald door radioligand-binding analyse op intacte cellen. Gastrine receptoren werden gedetecteerd op LS 174T, SW 403 en NCI-H716 cellen. Serotonine receptoren werden gevonden op SW 403 en NCI-H716 cellen. Receptoren voor somatostatine werden aangetoond op alle onderzochte cellijnen. In NCI-H716 cellen, die endocriene eigenschappen bezitten en receptoren voor alle drie de neurohormo- 
nen, bleek in competitie experimenten dat de gastrine antagonist CAM 958, de serotonine antagonist methysergide, en het somatostatine analogon octreotide (Sandostatin, SMS 201-995) competeerden met de bindingsplaatsen voor gastrine, serotonine en somatostatine, respectievelijk.

In alle cellijnen werd de proliferatieve respons in vitro op gastrine, serotonine en somatostatine gemeten door ${ }^{3} \mathrm{H}$-thymidine inbouw onder verschillende kweekcondities. Alleen gastrine en serotonine waren in nanomolaire concentraties in staat om proliferatie arrest van NCl-H716 cellen in serumvrije condities te voorkomen. Somatostatine had geen effect op proliferatie van NCI-H716 cellen. De overige cellijnen toonden geen gewijzigde ${ }^{3} \mathrm{H}$-thymidine inbouw onder invloed van gastrine, serotonine of somatostatine.

Het effect van liganden en hun antagonisten op celkinetiek van NCI-H716 cellen werd bestudeerd door twee-parameter flowcytometrie na pulse-labelen met 5-bromo-2'-deoxyuridine (BrdU). Gastrine had geen significante invloed op de kinetiek van NCI-H716 cellen. CAM 958 veroorzaakte een geringe remming van de proliferatie van deze cellen. Serotonine had een gering, doch significant remmend effect. Methysergide beinvloedde de proliferatieve activiteit niet. Terwijl somatostatine geen effect had, verlengde octreotide significant de potentiele verdubbelingstijd van NCI-H716 cellen, door verlenging van de $\mathrm{S}$-fase, zonder verandering van de labeling index. Dit impliceert dat er geen specifieke blokkades optreden in de $G_{0} / G_{1}$ fase, doch dat de passage van cellen door de celcyclus vertraagd wordt.

Hoewel de resultaten suggereren dat groei modulerende effecten van neurohormonen gemedieerd worden door receptoren, staat de aanwezigheid van deze receptoren niet garant voor het daadwerkelijk optreden van een proliferatieve respons van colon carcinoom cellen in vitro. Dergelijke effecten treden mogelijk in hoofdzaak op bij adenocarcinomen met neuroendocriene kenmerken. Somatostatine analogen zouden effectief kunnen zijn voor groei remming van deze tumorcellen.

\section{Hoofdstuk 7}

In dit hoofdstuk is de klinische relevantie van endocriene differentiatie in dikke darmkanker onderzocht. Het voorkomen van endocriene cellen in 350 gevallen van adenocarcinoom van de dikke darm werd onderzocht door immuunhistochemie op chromogranine A (CGA). Het hormoonprofiel van endocriene tumorcellen, de correlatie tussen endocriene differentiatie en de aanwezigheid van andere colorectale epitheliale cellijnen en de prognostische betekenis van endocriene differentiatie in dikke darmkanker werden onderzocht. CGA positieve tumorcellen werden gevonden in $30 \%$ van de gevallen, $21 \%$ met matige positiviteit $\left(<1 \mathrm{cel} / \mathrm{mm}^{2}\right)$, en $9 \%$ met sterke positiviteit $\left(>1 \mathrm{cel} / \mathrm{mm}^{2}\right)$. Van de CGA 
positieve tumoren produceerde $70 \%$ additionele neurohormonen, thuishorend in normaal dikke darmepitheel: $55 \%$ toonde immunoreactiviteit voor glucagonachtige substanties, $20 \%$ voor serotonine en $10 \%$ voor somatostatine, PYY en HCG. Er werd geen immunoreactiviteit gevonden voor diverse neurohormonen die normaliter niet geproduceerd worden door endocriene cellen in de dikke darm. CGA positieve tumoren neigden tot aggressiever gedrag dan CGA negatieve tumoren ( $\mathrm{p}=0.068)$. Vooral tumoren met sterke CGA positiviteit toonden een kortere overlevingsduur, hetgeen het meest uitgesproken was in Dukes' $\mathrm{C}$ stadium ( $\mathrm{p}=0.028$ ). In multivariaat analyse, was sterke CGA positiviteit een onafhankelijke indicator van een slechte prognose $(p=0.015)$. CGA immunoreactiviteit correleerde significant met slijm produktie, maar niet met expressie van secretoir component $(\mathrm{SC})$, een marker voor columnaire cellen. Slijm produktie correleerde significant met SC expressie. Tumoren die positief waren voor CGA maar niet voor slijm en/of SC hadden de slechtste prognose $(\mathrm{p}<0.001)$. SC expressie was een relatief gunstig kenmerk, en slijm producerende tumoren gedroegen zich intermediair.

\section{Hoofdstuk 8}

Dit hoofdstuk omvat de algemene discussie over de biologische en klinische relevantie van endocriene differentiatie in dikke darmkanker, en integreert hierbij gegevens van klinisch en fundamenteel onderzoek zoals gepresenteerd in voorgaande hoofdstukken. 



\section{DANKWOORD}

Het schrijven van een dankwoord is in zekere zin ondankbaar, aangezien aan dit manuscript zovelen een bijdrage hebben geleverd dat het bijna ondoenlijk is om een ieder bij name te noemen. Daarnaast weten de mensen die mij kennen dat woorden van dank juist niet de woorden zijn die het gemakkelijkst mijn mond verlaten. Laat het echter een ieder duidelijk zijn, dat ik zeer blij ben met alle steun die ik bij het verrichten van dit werk ondervonden heb.

Een aantal mensen wil ik in het bijzonder noemen.

De promotor, Prof.dr. F.T. Bosman. Beste Fré, jij bent van begin tot eind verantwoordelijk geweest voor het welslagen van deze onderneming, door mij met zachte drang het pad van de wetenschap op te leiden en bij mij een "endocriene antenne" te ontwikkelen, door mij te overtuigen van mijn eigen mogelijkheden, door -ook na je vertrek naar de Erasmus Universiteit- altijd tijd vrij te hebben willen maken voor overleg, en vooral door je uiterst snelle en kundige "ghostwriter-schap", waardoor de onderdelen van dit manuscript zonder problemen geaccepteerd werden voor publicatie. De begeleiding van deze promovendus was vaderlijk, dan weer broederlijk, maar altijd kameraadschappelijk. De ideale promotor.

De co-promotor, Dr. W.N.M. Dinjens. Beste Winand, door mij als "dolende" jonge onderzoeker bij de hand te nemen ben jij instrumenteel geweest voor de voortgang van het onderzoek. De momenten die wij samen door brachten in lab, kweek, proefdierenstal of achter het microscoop, waren even talrijk, nuttig als gezellig. Jouw vertrek naar Rotterdam was voor mij een tegenslag, maar ook jij bent van daaruit zeer actief geweest bij de begeleiding van het proefschrift. Ik waardeer het bijzonder, dat jij in deze voor jou zo moeilijke periode de moed hebt kunnen opbrengen om het co-promotorschap te aanvaarden.

De leden van de beoordelingscommissie, onder doortastend voorzitterschap van Prof.dr. G. Kootstra, dank ik voor de voortvarende wijze waarop zij het manuscript hebben getoetst, zodat de wachttijd tot de promotiedatum beperkt is gebleven. 
De co-auteurs uit de Vakgroep Pathologie. Ton de Goeij dank ik voor zijn inzet bij het schrijven van hoofdstuk 6 , en voor zijn deskundige adviezen en begeleiding van het receptorwerk, een samenwerking die in de nabije toekomst zeker gecontinueerd zal worden. Mede-promovendus Johan de Vries en zijn co-promotor Joop ten Kate hebben door hun Ras-transfectie experimenten een wezenlijke bijdrage geleverd aan hoofdstuk 5. De "vaste krachten" Edith van der Linden, Margriet Pijls, Mat Rousch, Cor Beek en Peter Moerkerk waren misschien wel de belangrijkste pijlers onder het hele onderzoek. Edith van der Linden, jouw zelfstandige en evenwichtige inbreng was onontbeerlijk bij het verrichten van celkweekwerkzaamheden, proefdierwerk en immunohistochemie. Margriet Pijls, ook jij stond altijd klaar voor het verlenen van immuunhistochemische hulp. Mat Rousch, jouw tomeloze inzet bij receptor- en proliferatiestudies, maar ook bij tal van andere "klussen" waren indrukwekkend. Gedenkwaardig waren de sessies met Cor Beek, zonder wiens computerknobbel de data van hoofdstuk 7 nog steeds niet bewerkt zouden zijn. De uitvoering van het moleculair biologisch werk was bij Peter Moerkerk in vertrouwde handen. Ook de hulp van Marie-Hélène Lenders (inmiddels Vakgroep Moleculaire Celbiologie en Genetica) wordt zeer gewaardeerd.

De externe co-auteurs. De inbreng van Theo Wiggers (Afdeling Chirurgie, Dr. Daniel den Hoed Kliniek, Rotterdam) bij hoofdstuk 7 was essentieel. Een kleine vijftien jaar (!) na het opzetten van de "Colontrial" blijft het bewondering oogsten hoe knap jij dit patientenbestand destijds in elkaar gezet hebt. Het enthousiasme waarmee je voor overleg vanuit Rotterdam naar Maastricht kwam was hartverwarmend. Lex Volovics en Marion de Leeuw (Medische Statistiek, RUL) worden bedankt voor hun hulp bij de statistische bewerking van de gegevens van hoofdstuk 7. Maarten von Meyenfeldt (Vakgroep Heelkunde, AZM) superviseerde bij het voltooien van de 10-jaars follow-up van de patiententrial, waarmee hij in belangrijke mate meegewerkt heeft aan de reactivatie van dit databestand.

Collegae staf en assistenten van de afdeling Pathologie, Prof.dr. J.W. Arends, beste Jan-Willem, ook jij wordt bedankt voor je inbreng bij hoofdstuk 7, en daarnaast voor de belangstelling en aanmoedigingen bij het verrichten van dit onderzoek. De overige stafleden en arts-assistenten dank ik voor de betoonde steun en voor de inzet bij het waarnemen van klinische taken die weleens zijn blijven liggen.

Sjaak Joosten, Jan Smeets en alle anderen van het histologisch laboratorium boden altijd spontaan hulp bij het bewerken van onderzoeksmateriaal. 
De dames van het secretariaat, met name Aggie Bronkhorst en "mijn eigen" Audrey van Golde, ben ik veel dank verschuldigd voor hun hulp als het "heel belangrijk" was en "liefst gisteren" weg moest.

Judith Kuypers en Paul Bomans waren van ultrastructureel belang.

Verschillende medische studenten hebben eveneens een rol gespeeld. Op de eerste plaats Han Zijlema, die vele uren in het donker heeft doorgebracht om zijn aandeel aan hoofdstuk 2 te leveren. Voorts Hans Biemans, die de colontrial voorzag van weer een aantal nieuwe immuunhistochemische markers, en ook nog actief was bij het scoren. Britta Gerdts voltooide de 10 -jaars follow-up voor hoofdstuk 7 op zeer charmante wijze, zodat ik nu uitzie naar de 15-jaars follow-up.

Medewerkers van de Audiovisuele Dienst van het AZM, de Medische Bibliotheek en de Centrale Proefdiervoorziening waren ieder op hun eigen wijze zeer behulpzaam.

Hubert Schouten (Medische Statistiek, RUL) gaf nuttige adviezen bij de statistische bewerking van hoofdstuk 2. Frank Kornips en Bert Schutte (Vakgroep Moleculaire Celbiologie en Genetica, RUL) verrichtten respectievelijk de karyotypering en DNA-flowcytometrie van NCI-H716 cellen. De integrine receptor antilichamen waren afkomstig van Dr. A Sonnenberg (Centraal Laboratorium voor de Bloedtransfusiedienst, Amsterdam). Heparan sulfaat proteoglycaan werd verstrekt door Dr. B. van den Heuvel (Afdeling Biochemie, KU Nijmegen). ${ }^{125}$ I-Tyr3-octreotride was een gift van Prof.dr. S.W.J. Lamberts (Afdeling Interne Geneeskunde, EU Rotterdam). Methysergide werd gedoneerd door Prof.dr. H. Struyker Boudier (Vakgroep Farmacologie, RUL). Dr. J. Hughes (Parke Davis Research Unit, Cambridge, UK) generously donated CAM 958.

Tot slot dank ik mijn ouders, die het mogelijk hebben gemaakt dat ik zo ver ben gekomen.

Zonder Sophie was dit alles nooit volbracht. Just, Eline en Isabelle: ik hoop dat ik vanaf nu wat van de verloren tijd kan gaan goed maken. 



\section{Curriculum vitae}

1957 Geboren te Comodoro Rivadavia (Argentinië)

1975 Eindexamen Gymnasium $\beta$

Maerlant Lyceum, Den Haag

1975 - 1982 Studie Geneeskunde

R.U. Leiden

1982 - 1984 Militaire Dienst Koninklijke Landmacht

arts-assistent Pathologische Anatomie, Diaconessenhuis-Militair Hospitaal Dr. A. Mathijsen-Ziekenhuis Oudenrijn, Utrecht

1984 - 1985 Arts-assistent Urologie

Westeinde Ziekenhuis, Den Haag

1985 - 1990 Opleiding Pathologische Anatomie Academisch Ziekenhuis Maastricht

Opleider: Prof.dr. F.T. Bosman

1990 - Patholoog

Academisch Ziekenhuis Maastricht

Hoofd: Prof.dr. J.W. Arends 
Datawyse I Universitaire Pers Maastricht

ISBN 9052780803 